\begin{abstract}
UNIVERSIDADE DE SÃO PAULO
Museu de Arqueologia e Etnologia

PROGRAMA DE PÓS-GRADUAÇÃO EM ARQUEOLOGIA
\end{abstract}

\title{
ANÁLISE DE ARQUEOFÁCIES NA CAMADA PRETA DO SAMBAQUI JABUTICABEIRA II
}

Ximena Suárez Villagrán 
UNIVERSIDADE DE SÃO PAULO

Museu de Arqueologia e Etnologia

PROGRAMA DE PÓS-GRADUAÇÃO EM ARQUEOLOGIA

\section{ANÁLISE DE ARQUEOFÁCIES NA CAMADA PRETA DO SAMBAQUI JABUTICABEIRA II}

Ximena Suárez Villagrán

Dissertação apresentada ao Programa de Pós-Graduação em Arqueologia, do Museu de Arqueologia e Etnologia da Universidade de São Paulo, para obtenção do título de Mestre em Arqueologia

Orientador: Prof. Dr. Paulo DeBlasis (MAE/USP)

Linha de Pesquisa: Processos de Formação do Registro Arqueológico

São Paulo

2008 
"Cuando observamos y registramos la realidad arqueológica (o manifestación del objeto) como "materia" arqueológica, ésta ofrece indicios de la naturaleza dinámica de su formación. Lo que queda de todo lo que desembocó en lo que ahora observamos, ese reducto que solemos definir como arqueológico, no sólo es el resto infinitesimal de una probable manifestación, ni tan siquiera la huella de su desintegración, sino una nueva manifestación. En el mejor de los casos, la evidencia arqueológica es un simple resto maltrecho de los sucesos que la produjeron. Ante esa situación, el/la arqueólogo/a procede mediante una metonimia, en virtud de la cual tomamos la parte (lo observado) por un todo que creemos existió"

P.V. Castro Martinez; Vicente Lull \& Rafael Mico Pérez (1993: 20). 


\section{AGRADECIMENTOS}

$>$ Á FAPESP

A orientação do Prof. Dr. Paulo DeBlasis e Prof. Dr. Paulo C. F. Giannini.

Ao Museu de Arqueologia e Etnologia e ao Instituto de Geociências da USP.

$>$ À Fundación Carolina

> A Marco Madella, Asunción Vila e Jordi Estevez do Departamento de Antropologia e Arqueologia da Instituição Milá e Fontanals (CSIC/ Barcelona).

$>$ A Paula Nishida e Milene Fornari.

Aos técnicos e estagiários dos Laboratórios de Sedimentologia e Petrografia Sedimentar (IGc/USP): Isaac, Elaine, Vitor, Rodolfo, Adriano, Simone e Rebeca.

$>$ A Daniela Klökler (University of Arizona), Paula Amaral (IGc/ USP), André O. Sawakuchi (IGc/ USP) e Wenceslau Teixeira (EMBRAPA).

$>$ À Profa. Dra. Maria Dulce Gaspar (UFRJ), Prof. Dr. Levy Figuti (MAE/ USP) e Prof. Dr. Felipe Toledo (IO/ USP).

Ao Prof. Dr. José M. López Mazz (UDELAR). 


\section{ÍNDICE}

ÍNDICE DE ILUSTRAÇÕES ............................................................................ 7

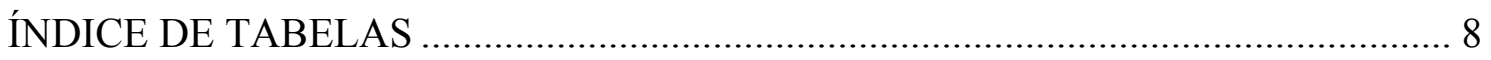

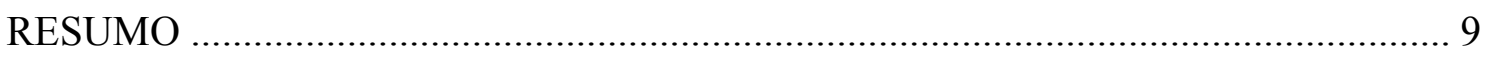

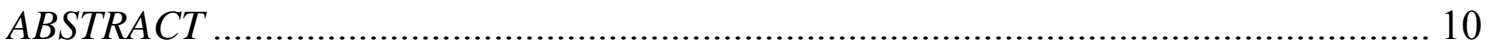

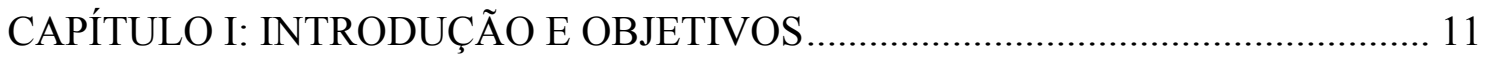

CAPÍTULO II: PROCESSOS DE FORMAÇÃO DE DEPÓSITOS

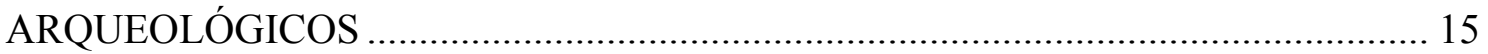

2.1. - A geoarqueologia e a dicotomia natural vs. cultural ....................................... 16

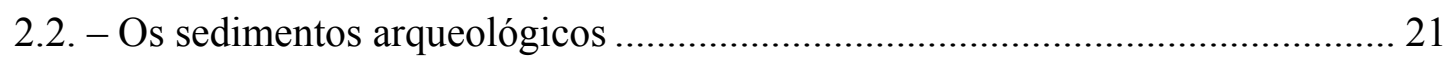

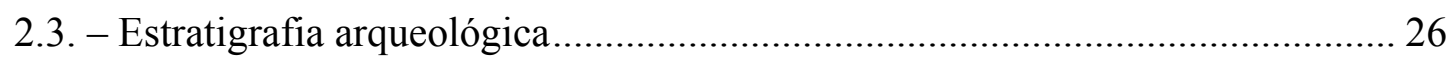

CAPÍTULO III: ANÁLISE DE FÁCIES EM ARQUEOLOGIA .................................... 31

3.1. - Fácies sedimentológicas e fácies arqueológicas .............................................. 32

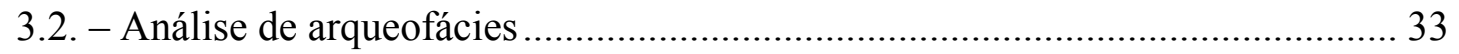

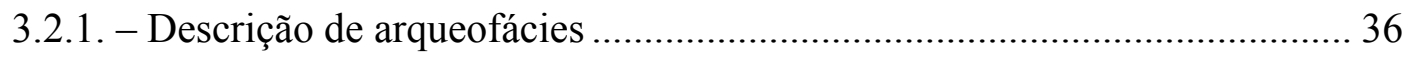

3.2.2. - Caracterização de arqueofácies ............................................................. 38

3.2.3. - Interpretação de arqueofácies ................................................................ 40

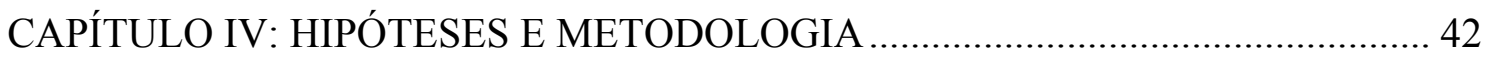

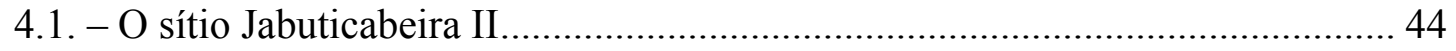

4.2. - Sistemas deposicionais da região de localização do sítio.................................. 49

4.3. - Procedimentos de campo e laboratório.............................................................. 51

4.3.1. - Descrição de arqueofácies ..................................................................... 51

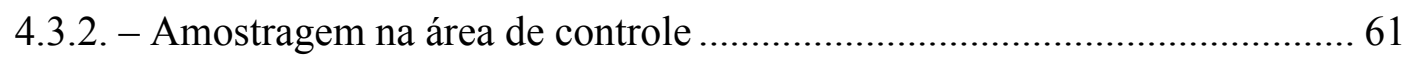

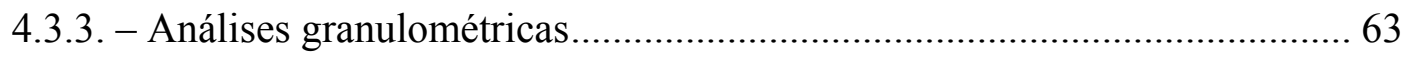

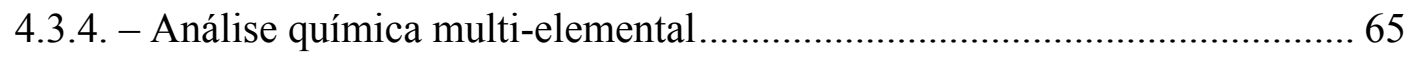

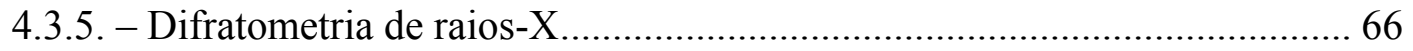

4.3.6. - Micromorfologia de depósitos arqueológicos ............................................. 66

4.3.7. - Microscopia eletrônica de varredura ........................................................ 70

CAPÍTULO V: APRESENTAÇÃO E DISCUSSÃO DOS RESULTADOS ................ 71

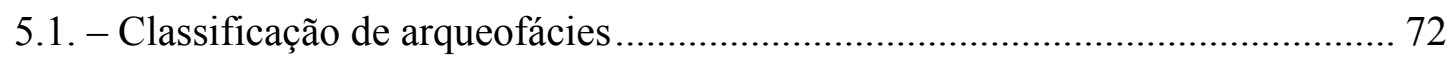

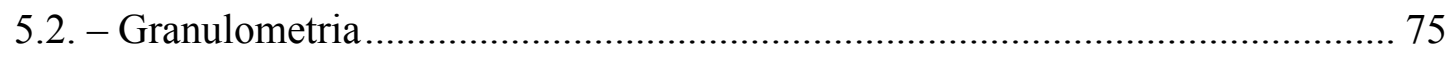

5.2.1. - Caracterização física dos sedimentos da área de controle........................ 75 
5.2.2. - Caracterização física de arqueofácies................................................... 82

5.2.3. - Comparação entre sedimentos naturais e arqueológicos ......................... 87

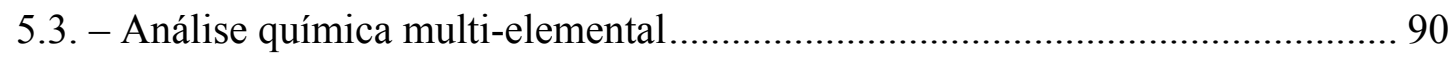

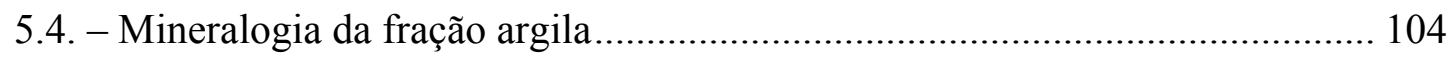

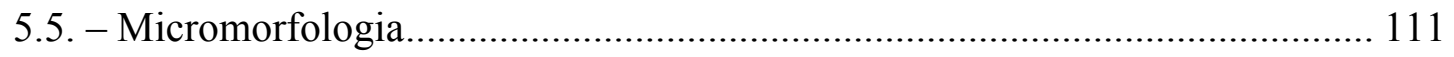

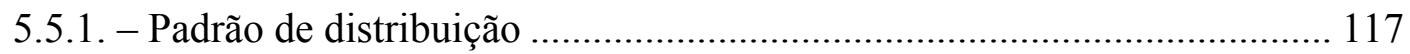

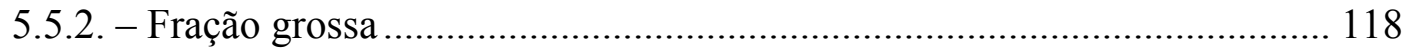

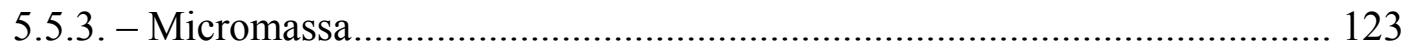

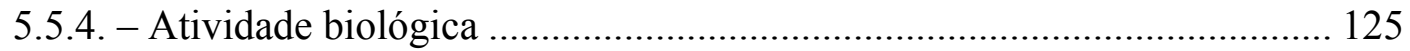

5.5.5. - Feições pedológicas ................................................................................ 128

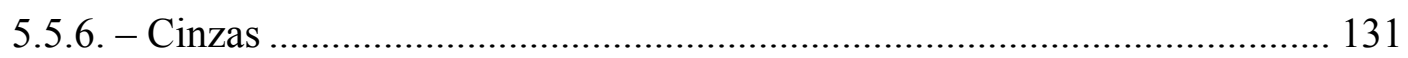

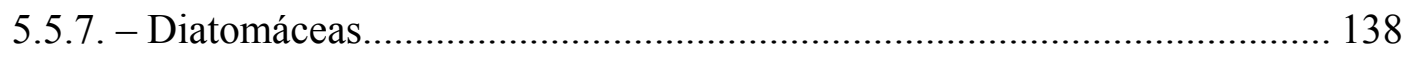

5.6. - Microscopia Eletrônica de Varredura.............................................................. 140

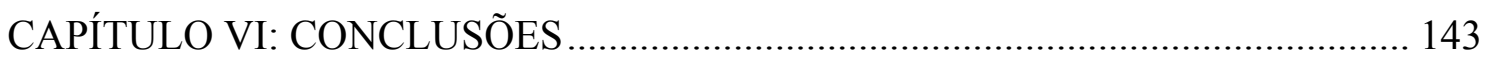

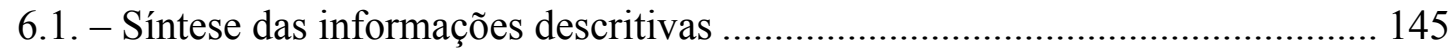

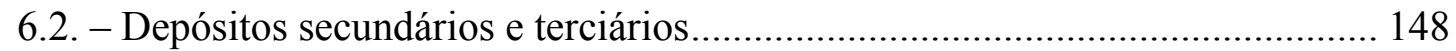

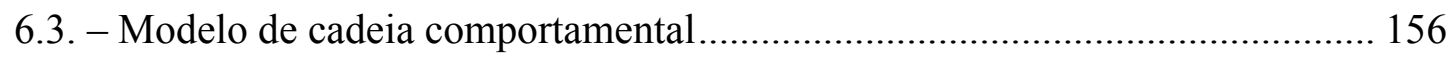

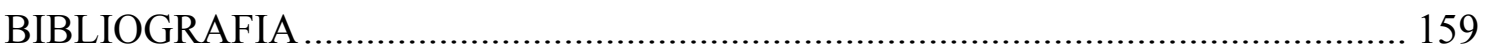




\section{ÍNDICE DE ILUSTRAÇÕES}

Fig. 1. - Mapa de localização do sítio Jabuticabeira II.....................................................................4

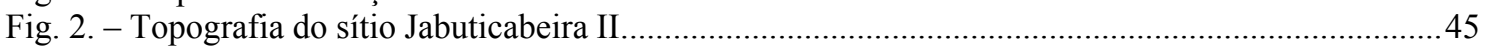

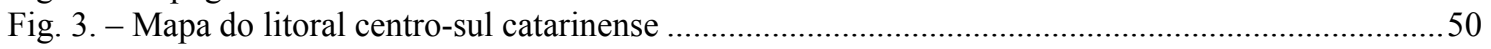

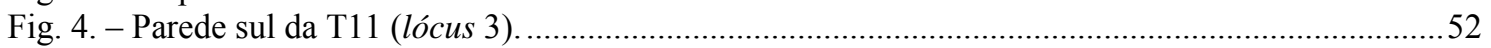

Fig. 5. - Seção estratigráfica vertical da parede sul da T11 (lócus 3). ...................................................53

Fig. 6. - Paredes leste e norte da T10 (lócus 3) .............................................................................5

Fig. 7. - Seção estratigráfica vertical das paredes leste e norte da T10 (lócus 3) ...................................58

Fig. 8. - Imagem de satélite do sítio com a localização ..................................................................62

Fig. 9. - Procedimento de extração de blocos inalterados de um perfil estratigráfico..............................69

Fig. 10. - Posição dos blocos inalterados para amostragem micromorfológica na T10 .........................69

Fig. 11. - Seção da T11 com arqueofácies e subfácies identificadas ....................................................73

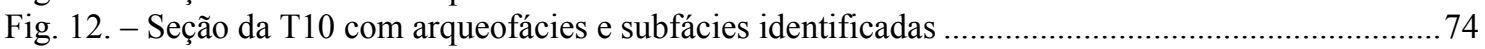

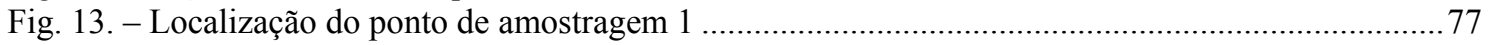

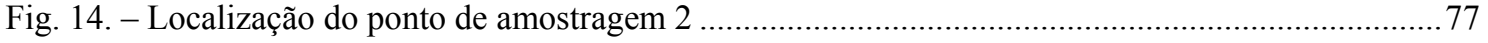

Fig. 15. - Localização do ponto de amostragem 3 .............................................................................. 78

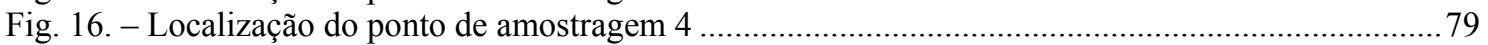

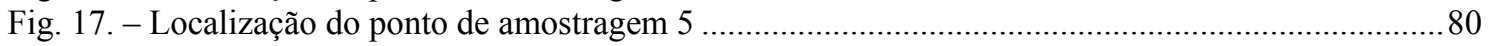

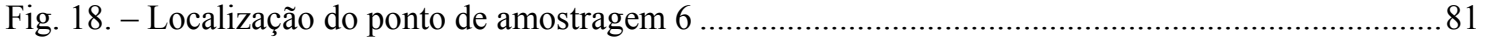

Fig. 19. - Localização do ponto de amostragem 7 ..........................................................................8 82

Fig. 20. - Histogramas da distribuição granulométrica para as arqueofácies da T11 ...............................86

Fig. 21. - Comparação de parâmetros estatísticos da distribuição granulométrica ..................................8 88

Fig. 22. - Diagramas de dispersão para os parâmetros estatísticos da fração areia ..................................90

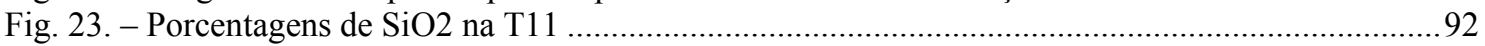

Fig. 24. - Concentrações de elementos maiores e menores..................................................................93

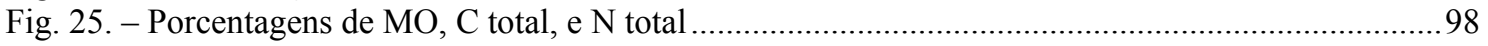

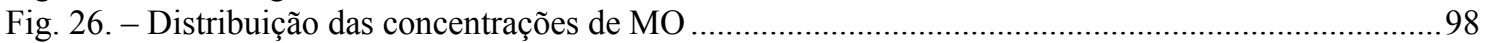

Fig. 27. - Porcentagens de C orgânico e C inorgânico e elementar ....................................................... 100

Fig. 28. - Concentração de elementos maiores e menores .................................................................. 103

Fig. 29. - Difratogramas dos minerais de argila na T11 e área de controle........................................ 105

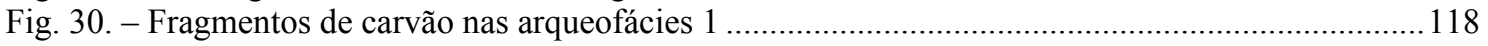

Fig. 31. - Massa basal composta por grãos de quartzo...................................................................... 119

Fig. 32. - Fitólitos e diatomáceas na camada preta ..................................................................... 121

Fig. 33. - Concentração de frústulas de diatomáceas entre restos arqueofaunísticos na ........................1121

Fig. 34. - Agregados de material silicoso ...................................................................................... 122

Fig. 35. - Seções estratigráficas da T10 e T11 com a localização das arqueofácies ............................... 124

Fig. 36. - Imagem de um possível excremento ou peloide localizado dentro de um canal .....................126

Fig. 37. - Evidências de atividade biológica na camada preta. ........................................................ 127

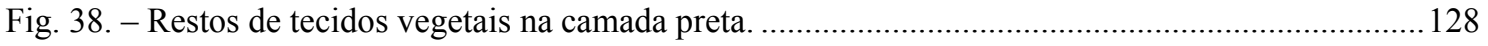

Fig. 39. - Encobrimentos em cúpula e pendulares .......................................................................... 129

Fig. 40. - Dois exemplos de nódulos anórticos ............................................................................130

Fig. 41. - Detalhe da composição interna do nódulo anórtico............................................................ 131

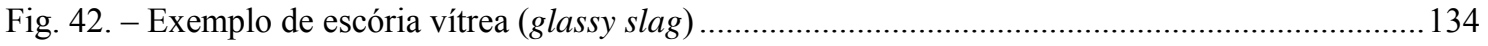

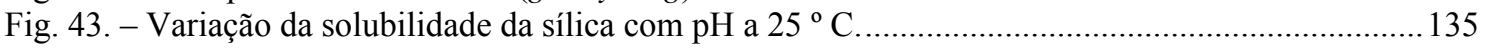

Fig. 44. - Condições limites para a alteração de calcita ....................................................................137

Fig. 45. - Espécies de diatomáceas identificadas na T10 e T11 .........................................................138

Fig. 46. - Espécies de diatomáceas identificadas na T10 e T11 .........................................................139

Fig. 47. - Fotomicrografias das superfícies de um fragmentos de carvão e osso ....................................141

Fig. 48. - Imagem obtida com o sensor de elétrons retroespalhados.............................................. 141

Fig. 49. - Imagem obtida com o sensor de elétrons retroespalhados na subfácies 2.1 ......................... 142

Fig. 50. - Imagem obtida com o sensor de elétrons retroespalhados na arqueofácies $1, \ldots \ldots \ldots \ldots \ldots \ldots \ldots \ldots . .142$

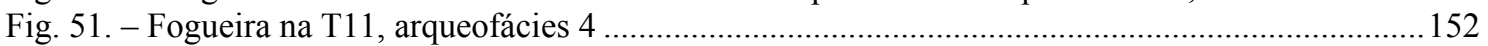

Fig. 52. - Modelo de cadeia comportamental para a formação da camada preta ..................................158 


\section{ÍNDICE DE TABELAS}

Tab. 1. - Descrição para análise de arqueofácies na T11 ..................................................................5

Tab. 2. - Descrição para análise de arqueofácies na T10 ...................................................................59

Tab. 3. - Arqueofácies e subfácies identificadas na T10 e T11 …....................................................72

Tab. 4. - Descrição micromorfológica das arqueofácies e subfácies na T10 …..................................112

Tab. 5. - Descrição micromorfológica das arqueofácies e subfácies na T11 


\section{RESUMO}

Este trabalho compreende uma abordagem teórico-metodológica para o estudo dos processos de formação (culturais e naturais) da camada preta que recobre o sítio Jabuticabeira II (Santa Catarina). A partir da adaptação da análise de fácies sedimentares foi desenvolvido um método para a descrição, classificação, caracterização e interpretação de sedimentos arqueológicos em sítios estratificados. Tal método foi desenhado para envolver numa mesma abordagem analítica os processos culturais e naturais como agentes ativos na configuração de corpos arqueossedimentares. $\mathrm{Na}$ camada preta do sítio Jabuticabeira II, a análise de arqueofácies proposta permitiu aproximar aos comportamentos deposicionais e processos naturais responsáveis pela conformação deste complexo fenômeno de deposição cultural.

Palavras chave: geoarqueologia - processos de formação de sítio - arqueoestratigrafia - comportamentos deposicionais - sambaquis. 


\title{
Archaeofacies analyses in the black layer of Jabuticabeira II sambaqui
}

\begin{abstract}
This work represents a theoretical and methodological approach for the study of formation processes (both cultural and natural) of the black layer that covers the Jabuticabeira II site (Santa Catarina). From adaptation of sedimentary facies analyses a method for classification, characterization and interpretation of archaeological sediments in stratified sites was developed. Such method aims to embrace in the same analytical approach both cultural and natural processes as active agents in the configuration of archaeosedimentary bodies. In the black layer of Jabuticabeira II, the proposed archaeofacies analyses allowed the approximation of depositional behaviours and natural processes responsible for the conformation of this complex phenomenon of cultural deposition.
\end{abstract}

Key words: geoarchaeology - formation processes - archaeostratigraphy depositional behaviours - sambaquis. 
CAPÍTULO I: INTRODUÇÃO E OBJETIVOS 
O presente projeto de mestrado forma parte do auxilio à pesquisa temático da FAPESP (04/ 11038-0): "Sambaquis e paisagem: modelando a inter-relação entre os processos formativos culturais e naturais no litoral sul de Santa Catarina”. Este projeto temático visa integrar dados provenientes de diferentes áreas do conhecimento (geologia, geofísica, antracologia, zooarqueologia, antropologia biológica etc.) para aproximar-se à evolução espaço-temporal da ocupação do litoral catarinense pelas populações construtoras de sambaquis. A interdisciplinaridade própria do projeto possibilitou o trabalho conjunto com profissionais de outras áreas, o que favoreceu a formação teórica e metodológica e permitiu conformar este mestrado numa verdadeira interface entre arqueologia e geociências.

O sítio Jabuticabeira II, objeto deste estudo, localiza-se nas proximidades da Lagoa de Garopaba do Sul no Município de Jaguaruna (Estado de Santa Catarina). Este sambaqui é considerado um cemitério comunal construído a partir de atividades rituais que adicionaram sucessivos estratos de conchas (principalmente Anomalocardia brasiliana) e sedimentos para cobrir múltiplos e diferentes sepultamentos humanos (DeBlasis et al. 1998; DeBlasis et al. 2004). Esta atividade perpetuou-se ao longo do tempo por meio de eventos incrementais que culminaram numa construção antrópica de importante envergadura.

Nos perfis estratigráficos do sítio observam-se três grandes camadas estratificadas: uma camada conchífera, na base, intercalada com finos estratos de sedimentos pretos; uma camada de conchas concrecionada (produzida na diagênese); e cobrindo o conjunto anterior uma camada preta (também chamada de "terra preta" ou "capa preta") de espessura decimétrica a métrica (DeBlasis et al. 1998; 2007; Fish et al. 2000; Gaspar et al. 2002; Bendazzoli 2007).

A camada conchífera tem recebido a atenção dos pesquisadores desde que o sítio começou a ser estudado. Esta camada esta composta por uma sucessão de estratos ricos em conchas que se intercalam com estratos onde predominam as areias quartzosas, os carvões ou as cinzas. Estratos pretos de espessura centimétrica, compostos por material orgânico fino e restos arqueofaunísticos, se dispõem intercaladamente ao longo do perfil da camada conchífera. Eles concentram o maior número de sepultamentos humanos, que aparecem geralmente acompanhados de artefatos líticos e malacológicos, estruturas de combustão e buracos de estaca, o que resultou na sua categorização como "camadas funerárias" (Fish et al. 2000). 
A relação constante entre estratos conchíferos e camadas funerárias foi interpretada como um padrão construtivo que envolve a deposição de materiais para recobrir os corpos dos defuntos e formar pequenos montículos. A associação deste padrão, de projeção fundamentalmente vertical, com atividades rituais mortuórias propiciou as interpretações do sítio como monumento funerário (Fish et al. 2000).

Em arqueologia, a utilização de áreas formais como cemitério vincula-se a estratégias de domínio territorial (Charles \& Buikstra 1983), já que a manutenção destas áreas está comumente associada à necessidade de controlar e legitimar, por intermédio dos ancestrais, o acesso a espaços de recursos restringidos (Saxe 1970; Brown 1995).

Segundo Criado (1993), a monumentalidade de uma estrutura esta dada pela sua visibilidade, independente da estrategia de subsistencia e grau de sedentarismo da população construtora. Contudo, a visibilidade do sítio Jabuticabeira II foi resultado da recorrência no tempo do seu uso como local de enterramento por parte das comunidades sambaquieiras. Este atributo teria sido atingido tardiamente já que, com base na cronologia do sítio, este monumento teria durado mais de 1.000 anos em ser erguido. Seria o ritual funerário e não a projeção espacial da estrutura o motor principal no desenvolvimento deste sambaqui.

Todas as inferências vinculadas com o caráter funerário deste sítio se baseiam em estudos realizados exclusivamente na camada conchífera e não na camada preta, que tem recebido menor atenção nas pesquisas. A construção da camada preta é considerada resultante de uma mudança no regime deposicional do sambaqui (Fish et al. 2000), em que as conchas foram substituidas por sedimentos compostos por ossos de peixe, carvão e areia. Este novo regime deposicional teria começado há aproximadamente 2.000 anos estendendo-se até o momento final de levantamento do sítio, cerca de 1.300 anos atrás.

Até o momento, têm se realizado unicamente estudos arqueofaunísticos (Nishida 2007) e arqueoestratigráficos (Bendazzoli 2007) para estudar o processo de formação da camada preta. Tais estudos indicaram duas semelhanças na formação dos dois corpos arquessedimentares que compõem o sambaqui Jabuticabeira II: o uso de restos arqueofaunísticos como material construtivo, conchas na camada conchífera e ossos na camada preta; e a continuidade, na camada preta, do padrão construtivo que envolve o levantamento de montículos associados a sepultamentos humanos.

O objetivo geral deste trabalho envolve a avaliação da extrapolação do padrão construtivo e funcional proposto para a camada conchífera à camada preta. Como corolario pretende-se ponderar o ritual funerário como elemento igualmente 
significativo nesta porção tardía do sítio, para interpretar se a mudança no material construtivo vincula se ou não a uma modificação na sua funcionalidade.

A partir da configuração atual da camada preta pretende-se, especificamente, conhecer os processos de deposição e alteração culturais e naturais que têm conformado e afetado o depósito ao longo da sua evolução, tanto no contexto sistémico como arqueológico (sensu Schiffer 1972). Estes elementos do registro permitirão determinar o papel ativo dos sedimentos arqueológicos que constituem a camada preta na vida das populações sambaquieiras.

Portanto, esta dissertação está organizada da seguinte maneira: no capítulo II desenvolve-se uma discussão teórica sobre o papel da geoarqueologia nos estudos sobre processos de formação de sítio. Discute-se o significado dos processos de formação definidos por Michael Schiffer $(1972 ; 1983 ; 1987)$ do ponto de vista da arqueologia comportamental e da geoarqueologia, a definição dos denominados "sedimentos arqueológicos" nos quais se baseia este estudo, e dos sistemas arqueoestratigráficos mais utilizados em arqueologia. Tal discussão pretende introduzir ao leitor na necessidade de um modelo de análise arqueoestratigráfica que permita ir além da descrição dos perfis em termos de ajuda à escavação e de valorização seqüencial da constituição dos sítios arqueológicos. No capítulo III, portanto, apresenta-se a "análise de arqueofácies" elaborada como ferramenta geoarqueológica para o estudo dos processos de formação de sítio a partir dos perfis arqueoestratigráficos. Este método integra à geoarqueologia a análise de fácies sedimentares, método fundamental na geologia moderna para o estudo de processos e sistemas deposicionais passados. No capítulo IV introduz-se na realidade do sítio arqueológico sob estudo, nas hipóteses que fundamentam este trabalho e nos métodos analíticos escolhidos que, inseridos na análise de arqueofácies, permitirão aproximar-se dos objetivos propostos. O capítulo $\mathrm{V}$ agrupa os resultados e a discussão derivada das análises realizadas, e o capítulo VI concentra as conclusões alcançadas por esta pesquisa. 
CAPÍTULO II: PROCESSOS DE FORMAÇÃO DE DEPÓSITOS ARQUEOLÓGICOS 
Este trabalho inscreve-se dentro da subdisciplina arqueológica conhecida como geoarqueologia, considerada atualmente como a aplicação de qualquer conceito, técnica ou conhecimento proveniente das geociências nas três etapas fundamentais de toda investigação arqueológica: desenho, escavação e análise (Renfrew 1976; Gladfelter 1981; Butzer 1989; Leach 1992; Waters 1992; Rapp \& Hill 1998).

Porém, a interface entre geociências e arqueologia, que só mediante um marco de trabalho geoarqueológico pode ser realizada, vai além do simples empréstimo técnico e conceitual; geoarqueologia não envolve exclusivamente o aproveitamento dos métodos, mas a sua escolha diferencial, sua adaptação à escala dos estudos humanos e a interpretação dos seus resultados dentro do contexto da antropologia e da arqueologia.

Desta maneira a geoarqueologia, com seus numerosos e variados objetos de estudo, proporcionará válidas interpretações antropológicas das comunidades do passado através da adaptação e aplicação de procedimentos provenientes das geociências no estudo de fenômenos arqueológicos.

\section{1. - A geoarqueologia e a dicotomia natural vs. cultural}

Segundo Michael Schiffer (1972; 1983; 1987), a correta análise da formação dos sítios requer a consideração de três diferentes processos afetando os artefatos. Um desses processos é responsável pela criação do registro e compreende a maneira em que os objetos são procurados, usados, mantidos e descartados, criando padrões artefatuais em várias locações. Os outros dois processos encarregam-se de alterar esse padrão comportamental original e incluem: a ação das pessoas, contemporânea e posterior à deposição; e os efeitos de uma grande variedade de agentes naturais. Estes processos afetam o tamanho dos artefatos, sua forma, integridade, quantidade, distribuição, densidade etc.

Logo após a divulgação do trabalho de Schiffer, os processos de formação de sítio passaram a ser cruciais em arqueologia, já que os arqueólogos precisavam distinguir os padrões criados por comportamentos antigos daqueles que resultaram de processos naturais e culturais tardios. Foi o reconhecimento dos processos naturais que afetam o 
registro comportamental que intensificou a utilização dos métodos das geociências em arqueologia, tornando-os parte integrante das análises de formação de sítio.

Em arqueologia, existem duas perspectivas diferentes de avaliação dos processos de formação de sítio. Uma é a perspectiva dos artefactos, que envolve a avaliação dos processos culturais de configuração e alteração do padrão comportamental de deposição. Outra é a perspectiva pós-deposicional, preocupada com os efeitos dos processos não-culturais na formação do registro.

A perspectiva artefactual tornou-se objeto da arqueologia comportamental e a perspectiva pós-deposicional da geoarqueologia, que integrou os métodos das geociências no estudo dos processos de formação naturais. Desta maneira, a frase "processos de formação" significa coisas diferentes para pessoas diferentes: para os arqueólogos comportamentais significa procura de leis comportamentais que remetem ao contexto sistêmico ${ }^{1}$ (sensu Schiffer 1972); e para os geoarqueólogos significa procura dos processos de formação associados com o contexto arqueológico (Stein 2001a: 47-48).

Assim, os primeiros trabalhos geoarqueológicos encarregavam-se da avaliação dos processos de formação naturais que criam e transformam o registro arqueológico (Hassan 1979; Gladfelter 1981; Butzer 1989; Leach 1992; Waters 1992). Segundo autores como Gladfelter (1981: 348), assim como era trabalho dos arqueólogos considerar as transformações culturais depois que os artefatos foram depositados, era trabalho dos geoarqueólogos lidar com as transformações naturais que alteram a deposição cultural original. Portanto, os primeiros estudos geoarqueológicos eram concebidos na época como o estudo dos solos e sedimentos nos sítios para determinar as circunstâncias envolvidas na localização dos artefatos (Renfrew 1976), por exemplo, ou o estudo do contexto geomorfológico deles para reconstruções paleoambientais (Gladfelter 1977).

Os processos de formação eram então concebidos como um estudo geoarqueológico dividido em duas disciplinas: arqueologia vinculada aos processos culturais, tanto os que deram lugar ao registro artefactual como os que podem tê-lo modificado após o abandono dos sítios; e geociências, que ajudariam na análise das

\footnotetext{
${ }^{1}$ Segundo Schiffer (1972) um elemento participando ativamente de um sistema cultural encontra-se no contexto sistêmico. Quando este material é abandonado pelo grupo e passa a ser objeto da investigação arqueológica, encontra-se então no contexto arqueológico.
} 
alterações sofridas pelos artefatos por agentes naturais após o momento final de deposição.

A dicotomia resultante das propostas de Schiffer contrapunha processos de formação culturais vs. naturais e origem deposicional vs. pós-deposicional (Sanchez \& Cañabate 1998). Embora tal dualidade exista, esta associação trouxe o perigo de associar deposicional com padrões culturais originais (objeto da arqueologia) e pósdeposicional com alteração natural desse padrão (objeto da geoarqueologia). Desta maneira, simplificou-se a dificuldade intrínseca de separar a natureza cultural e natural dos processos deposicionais e pós-deposicionais.

Vários autores elaboraram suas teorias percebendo este fato e tentando afastar-se das propostas de Schiffer. Leonardi (1992), por exemplo, elaborou um modelo para o total da seqüência estratigráfica (do depósito) que integra a geologia sedimentar com as atividades antrópicas. $\mathrm{O}$ modelo de Leonardi classifica os materiais em função da sua organização espacial tridimensional, e decodifica a estratificação arqueológica desde um ponto de vista genético-processual, onde se incluem os processos pós-deposicionais, tanto de natureza antrópica como natural.

Na mesma linha de análise, a formulação dos processos pós-deposicionais de Bate (1993) resulta por demais interessante. Segundo este autor, é impossível marcar um limite concreto entre os processos deposicionais e os pós-deposicionais que atuaram num sítio arqueológico e assumir uma sucessão intercalada entre eles. Esses processos formadores do contexto não seriam únicos e singulares, mas recorreriam de modo complexo devido ao movimento constante e reiterativo da vida cotidiana das sociedades e à dinâmica dos sistemas naturais.

Molinos et al. (1993) definiram três conjunturas diferentes que identificam à configuração dos sítios ao longo da sua história de vida, e que resultam muito úteis no entendimento do papel ativo dos processos deposicionais e pós-deposicionais na formação dos sítios: a conjuntura de descoberta, que corresponde ao que é encontrado no sítio pelo arqueólogo, formada por processos deposicionais e pós-deposicionais antigos e modificada por processos pós-deposicionais tardios; a conjuntura zero, que envolve os restos de um sistema de atividades produzido pelo processo continuado de deposição cultural; e a conjuntura de abandono, momento final da conjuntura zero.

Segundo os autores, quando o arqueólogo enfrenta a conjuntura de descoberta para alcançar a conjuntura zero, deve lembrar que esta envolve a superposição potencial de uma série de eventos. Estes eventos podem ser: deposicionais relacionados com o 
processo continuado de ocupação ou com o processo destrutivo intradeposicional (correspondem a lugares de atividade transformados no processo de deposição por outras atividades); deposicionais da conjuntura de abandono (correspondem ao padrão deposicional das atividades realizadas no último momento de ocupação do local); pósdeposicionais neoconstrutivos (produzidos pós-deposicionalmente, mas que formam parte de um processo deposicional posterior); pós-deposicionais destrutivos ou de abandono (produto da instabilidade de alguns elementos da conjuntura zero como paredes caídas, tetos etc.); e pós-deposicionais produzidos pela ação de agentes naturais (i.e. agentes físicos, químicos, biológicos, geológicos) que começam a atuar sobre a conjuntura zero uma vez abandonado completamente o sítio e deixado à ação da natureza, a qual se encarregará de modificar o registro até alcançar a conjuntura de descoberta.

Sob esta perspectiva, o pós-deposicional pode ser deposicional se tem caráter neoconstrutivo, e pode, portanto, formar parte do processo deposicional da fase seguinte e, ao mesmo tempo, da anterior; e o pós-deposicional tradicionalmente concebido, ou seja, as alterações naturais, compreendem somente uma parcela dos tantos processos de alteração que um depósito pode sofrer.

Segundo Sanchez \& Cañabate (1998), quando se fala de processos de formação de depósitos, tenta-se aproximar da seqüência de um assentamento. Esta seqüência compreende processos de deposição, abandono e freqüentemente reocupação e envolve a interação de forças tanto de origem cultural como natural. Portanto, a conjuntura de descoberta revelada durante a escavação deve ser abordada ciente da superposição de processos deposicionais e pós-deposicionais ao longo da história dos sítios.

A diferença entre deposicional e pós-deposicional em sítios arqueológicos não é exclusivamente de tempo nem de natureza; envolve uma complexa interação e superposição de eventos relacionados com a dinâmica dos depósitos arqueológicos. Os processos pós-deposicionais podem acontecer no contexto sistêmico, assim como no arqueológico, e sua natureza cultural ou natural não esta necessariamente ligada à passagem dos elementos de um contexto ao outro.

A dicotomia cultural vs. natural também provocou uma dissociação entre registro artefatual e registro sedimentar dos sítios, que vários autores ainda consideram muito relacionados mas que devem ser estudados separadamente por incluir tipos diferentes de informação. Os artefatos são comumente considerados recipientes de informação 
cultural e comportamental, enquanto que os sedimentos são considerados fonte de informação paleoambiental e de processos de formação naturais.

Pela natureza dos corpos arqueossedimentares, separar o conteúdo (os artefatos) do recipiente (os sedimentos) e considerar os primeiros como fonte exclusiva de informação socio-econômica, à parte dos fenômenos sedimentares, constitui um grande erro (Vila \& Estevez 2000). Artefatos e sedimentos estruturam conjuntamente os depósitos arqueológicos e não podem ser considerados separadamente no estudo dos processos de formação.

Quando o interesse se concentra no processo de formação que resultou no conteúdo tanto sedimentar como artefatual de um sítio arqueológico, o depósito passa a ser a unidade de estudo por excelência, já que exige considerar o registro além da dicotomia natural/cultural (Stein 1987; 1990; 2001a); isto é, como um ou vários eventos deposicionais que podem incluir ambos os processos.

As propostas de Schiffer e a dicotomia natural vs. cultural posicionaram a geoarqueologia como a disciplina a cargo de estudar os processos de formação naturais de caráter pós-deposicional a partir da análise do registro sedimentar dos sítios. Como tem-se visto ao longo deste tópico, tais correlações não consideram o fato de que as alterações pós-deposicionais (naturais ou culturais) também acontecem quando os elementos formam parte de um sistema cultural ativo, e acabam dissociando o registro artefatual do sedimentar dos sítios como fontes de informação distinta, comportamental e ambiental respectivamente. Não obstante, os sedimentos são também uma importante fonte de dados culturais e comportamentais e, junto com os artefatos e ecofatos, provêem de completa valorização dos processos de formação de qualquer natureza ao longo da história dos depósitos arqueológicos.

Com a ajuda de um método adequado, a geoarqueologia pode realizar um estudo integral dos processos de formação que dé conta da ação de forças naturais, culturais, deposicionais e pós-deposicionais atuando nos depósitos arqueológicos. 


\section{2. - Os sedimentos arqueológicos}

Numerosos termos têm sido utilizados para descrever o registro sedimentar próprio dos depósitos arqueológicos (ou registro arqueossedimentar): sedimento arqueológico ou antropogênico, solo antrópico, antrossolo, sedimento ou depósito antrópico e arqueossedimento (Stein 1985: 6). Porém, a falta de unidade dos conhecimentos sobre a sedimentologia dos sítios arqueológicos tem impedido a utilização de uma linguagem comum, misturando-se conceitos semântica e sintaticamente diferentes.

Em arqueologia ainda pode-se sentir a falta de uma linguagem e de um modelo unificado que dê conta do registro arqueossedimentar dos sítios. Cada investigador parece fazer uma escolha, poucas vezes justificada, de determinada terminologia específica, sem considerar o significado por trás dos conceitos utilizados.

O uso diferencial da terminologia envolve graves conseqüências conceituais, já que, assim como sedimento não é solo, sedimento arqueológico ou antropogênico também não é solo antrópico nem antrossolo. Diferentes processos estão envolvidos na sua origem, e estes freqüentemente não são considerados no momento de adoção das terminologias. A definição formal de solo e sedimento ajudará a esclarecer este tema e a assinalar suas diferenças intrínsecas do ponto de vista genético e conceitual, assim como suas incompatibilidades.

A definição etimológica literal de sedimento, a partir da sua raiz latina sedis, refere a aquilo que se deposita, que se depositou ou que é passível de se depositar. Essa deposição implica movimento e transporte físico de materiais sólidos, ou transporte químico de solutos que se transformam em matéria sólida na deposição a partir de íons (Giannini \& Riccomini 2000: 170). Uma definição formal de sedimento em termos de processos geológicos maiores envolve um agregado de partículas minerais inconsolidadas, formado a partir do intemperismo da rocha fonte, transporte (físico ou químico) e deposição das partículas resultantes (Suguio 1998). Porém, um sedimento não é necessariamente de origem mineral (pode ser orgânico); nem tem de envolver um agregado de partículas (uma partícula isolada pode também ser considerada um sedimento ou material sedimentar, como alguns geólogos preferem chamar); nem tem 
de ser formado a partir do intemperismo de uma rocha fonte (pode derivar de restos de plantas, por exemplo).

Portanto, o conceito de sedimento admite uma multiplicidade de situações passíveis de serem envolvidas nesta categoria geológica, sempre e quando tenha existido transporte (físico ou químico) e deposição. Não obstante, um elemento excluise claramente da categoria de sedimento: os mantos de alteração in situ, formados por processos intempéricos, que não envolvem transporte mecânico e que incluem a formação de um solo na sua camada superior (Giannini \& Riccomini 2000: 171).

Os solos, por sua vez, são corpos naturais que consistem em camadas (horizontes) de constituintes minerais e orgânicos. Trata-se de entidades dinâmicas, que adquirem progressivamente suas propriedades pela ação combinada dos fatores do meio: nascem e evoluem (Duchaufour 1975). Os cinco fatores responsáveis pela formação de solos são: i. materiais parentais, pois o solo pode formar-se in situ a partir do intemperismo da rocha-mãe ou a partir de sedimentos transportados mecanicamente; ii. organismos, incluindo fauna do solo, plantas e microorganismos; iii. topografia, forma e relevo da paisagem; iv. o clima, que afeta o deslocamento e a transformação dos materiais, e influencia o tipo e a quantidade de vegetação suportada pelo solo; e v. o fator tempo, porque a formação de solos é um processo dinâmico e evolutivo (Herz \& Garrison 1998; Birkeland 1999).

Sedimentos e solos são entidades diferentes, embora os primeiros possam prover em alguns casos o material parental para o desenvolvimento dos segundos e embora alguns sedimentos correspondam a material de solo mecanicamente transportado. Definitivamente, não se trata de categorias equivalentes e este fato nem sempre é entendido na prática arqueológica, especialmente no campo onde a ausência do especialista (o geoarqueólogo) pode derivar em descrições incorretas.

Termos como antrossolo, solo antrópico ou antropogênico envolvem a existência de um perfil de solo já desenvolvido. O uso do termo antrossolo ou solo antrópico em campo requer a satisfação de vários aspectos da sua definição: presença de objetos arqueológicos dentro de um solo desenvolvido, matrizes escuras (pela alta concentração de matéria orgânica), limites abruptos entre horizontes e maior extensão territorial que os solos naturais da região (produto da deposição antrópica) (Holliday 2004). Todos estes atributos são produzidos de maneira não intencional como resultado da influencia humana, enquanto os solos antropogênicos são considerados como intencionalmente alterados (Eidt 1985). 
Estes tipos de solo só podem ser definidos pela presença de um horizonte superficial diagnóstico que pode ser tanto um horizonte antrópico como plaggen, ambos produzidos pela influência humana, mas de distintas maneiras. Os horizontes antrópicos requerem alguma evidência de alteração produzida pela atividade humana, assim como altas concentrações de fosfato, enquanto que os horizontes plaggen são considerados o produto exclusivo da adição prolongada e continuada de adubo (Duchaufour 1975; Herz \& Garrison 1998; Soil Survey Staff 1998).

Portanto, somente quando se tem absoluta certeza de estar frente a alguma das situações mencionadas, em função dos atributos de cada horizonte diagnóstico e tipo de solo e do fato de que sua identificação requer de análises laboratoriais e não simplesmente de descrições em campo, pode-se então usar a terminologia derivada da ciência do solo. Em demais situações, o que envolve a maioria dos sítios arqueológicos, terminologia diferente deve ser usada para permitir descrições padronizadas do registro arqueossedimentar.

Uma situação semelhante pode-se observar na terminologia derivada da sedimentologia, onde se faz presente a influência das propostas de Schiffer (1987). Por exemplo, arqueossedimentos ou sedimentos antrópicos são freqüentemente definidos como os produtos da deposição humana em contextos primários que não sofreram alterações pós-ocupacionais (Rapp \& Hill 1998; Dincauze 2000; Brochier 2002). Não obstante, concorda-se com o dito por Courty (2001) sobre o quão confusas resultam as definições que envolvem intenção. Assim como pode ser difícil de distinguir em campo um solo antrópico de um solo antropogênico, também é difícil determinar se um sedimento está em contexto primário e se sofreu ou não de alterações pós-ocupacionais, sem a ajuda de análises de laboratório.

Portanto, o conhecimento dos significados por trás da terminologia, seja derivada da ciência do solo seja da sedimentologia, é necessário na categorização do registro arqueossedimentar numa primeira aproximação. Os diferentes termos são de fato úteis, mas só após o completo escrutínio dos atributos e propriedades do material com o qual se está tratando, que freqüentemente vai envolver análises no laboratório além da descrição em campo para classificar corretamente e outorgar valor interpretativo ao registro arqueossedimentar.

Julie Stein (1985) propôs o termo sedimento arqueológico para se referir às partículas que foram afetadas por processos artificiais e que contêm informação sobre atividades culturais relevantes ao pré-historiador. Esta definição de sedimento 
arqueológico resulta num válido ponto de partida; o conceito enfatiza o caráter antrópico da sua origem e remete a materiais que têm incluido a ação humana embora a natureza dessa ação seja ainda desconhecida, e possa ter acontecido tanto sobre um solo como um sedimento. Assim, este termo pode ser usado numa grande variedade de situações descritivas iniciais que podem ser refinadas posteriormente.

O fato de que todos os depósitos arqueológicos sejam tratados em termos de sedimentos arqueológicos não exclui a possibilidade de se chegar à conclusão de que se está diante de um antrossolo, por exemplo, ou de um sedimento em contexto primário (sensu Schiffer 1987). A terminologia adotada neste trabalho, sedimentos arqueológicos, é ampla e geral, útil para ser usada em campo e sem implicações interpretativas a priori.

Sem dúvida, embora todos os sítios arqueológicos estejam compostos de sedimentos arqueológicos, algumas distinções devem ser feitas sobre a natureza destes materiais. A composição dos depósitos arqueológicos é, em termos gerais e descritivos, semelhante à dos solos e depósitos sedimentares; todos podem igualmente incluir: uma fração clástica, uma fração iônica e uma fração coloidal. Porém, a grande particularidade dos sedimentos arqueológicos é que, diferentemente dos solos e sedimentos geológicos, eles envolvem uma constituição antrópico-natural.

Nos sedimentos arqueológicos, os artefatos e as partículas de origem natural podem ter sofrido transporte e deposição que resultaram da ação humana de coletar, deslocar e colocar elementos num local determinado. Portanto, vários dos componentes dos sedimentos arqueológicos estão relacionados com um agente de transporte que não é considerado na sedimentologia tradicional: os humanos (Stein 1987; 2001b). Desta maneira, a influência antrópica que distingue sedimentos arqueológicos de solos e sedimentos naturais pode apreciar-se em cada uma das três frações citadas anteriormente, da seguinte maneira:

1. Na fração clástica: os sedimentos arqueológicos podem incluir artefatos, no sentido de produtos materiais definidos pelo sistema econômico básico ${ }^{2}$; e podem incluir partículas minerais (inorgânicas por definição) ou orgânicas que tenham sofrido um transporte antrópico até seu lugar final de deposição.

\footnotetext{
${ }^{2}$ Que implica a existência de um recurso natural, uma força de trabalho e meios de produção para dar lugar a objetos e artefatos socialmente produzidos (Risch 1998)
} 
2. Na fração iônica: a ação antrópica pode alterar a composição química original dos solos ou sedimentos e mudar as concentrações elementais, dando lugar a uma situação totalmente distinta da original.

3. Na fração coloidal: a ocupação pode introduzir matéria orgânica ou argilominerais nos sítios, ou pode resultar na transformação, neoformação ou destruição de argilominerais.

A ação humana intensiva num local modifica o material sedimentar ou edáfico, introduzindo materiais naturais e culturais forâneos através do processo de transporte e deposição antrópicos. Holliday (2004: 296) define o termo "metapedogênese" para se referir a esses processos antrópicos que resultam em mudanças nos perfis dos solos e sedimentos naturais, os quais se apresentam como material parental para as modificações induzidas pela ocupação humana. Pope \& Rubenstein (1999: 258) chegam a considerar as pessoas dentro dos agentes de intemperismo, e definem o termo "antrointemperismo" para referir-se aos processos bioquímicos e mecânicos únicos introduzidos pela ocupação humana e que não se acham ativos no ambiente natural.

Assim, os sedimentos arqueológicos são únicos porque representam a interface dos humanos com a sedimentação natural e a pedogênese (Courty et al. 1989), mas sua verdadeira particularidade reside no processo que está por trás da sua conformação: a ação humana. Da mesma maneira, os sedimentos arqueológicos possuem características assimiláveis tanto a sedimentos como a solos naturais. Com os sedimentos, compartilham a constituição por materiais que sofreram transporte, deposição e potenciais alterações diagenéticas que, ao mesmo tempo, incluem à pedogênese. Portanto, com os solos, compartilham o processo dinâmico de formação, que envolve uma transformação pós-deposicional ao longo do tempo que resulta, em função da intensidade da ocupação humana, num depósito novo.

Porém, deve-se evitar considerar a ação humana num depósito como um mero processo pós-deposicional, já que esta ação envolve um continuum de causas e efeitos cultural-natural, em parte regido pelas leis da física, mas principalmente controlado por fatores culturais e comportamentais.

Para finalizar, do ponto de vista descritivo, os sedimentos arqueológicos definemse como um conjunto de partículas minerais ou orgânicas misturadas a material arqueológico que podem ser produzidas pelo homem, ou transformadas posteriormente à sua deposição pelo homem (Courty \& Miskovsky 2002: 449). Do ponto de vista interpretativo, os sedimentos arqueológicos envolvem a ação combinada de processos 
culturais e naturais e possuem informação sobre o comportamento humano que participou na sua configuração. Conseqüentemente, a mera modificação de um depósito natural por resíduos de atividades humanas não é suficiente para chamar um sedimento de arqueológico, se não pudermos extrair dessa modificação informações sobre o comportamento humano pretérito.

\section{3. - Estratigrafia arqueológica}

Em arqueologia, a estratigrafia dos sítios geralmente apresenta-se como uma ferramenta de ajuda à escavação, como uma cronologia relativa dos elementos artefatuais, ou como testemunha da evolução ambiental dos sítios; e sua descrição muitas vezes se considera um objetivo a mais dentro das pesquisas.

Porém, a noção dos solos e sedimentos como unidade estática onde os artefatos repousam placidamente após a sua deposição final é altamente questionável, como disse Paola Villa (1982: 287):

"Conjoinable pieces have clearly indicated that considerable vertical movement can occur in the absence of visible traces of disturbance. Such displacement -which can be either post-depositional or contemporaneous with the time of burial-alters the original stratigraphic relationships of archaeological items and creates false stratigraphic associations. /.../ unless proven otherwise, layers and soils should be considered as fluid, deformable bodies /.../ through which archaeological items float, sink, or glide”.

Portanto, a menos que se esteja trabalhando com estruturas arquitetônicas, associar um conjunto artefatual inequivocamente com uma unidade sedimentar é um procedimento que requer escrutínios mais exaustivos do que o tradicionalmente feito. Igualmente, a estratigrafia dos sítios nem sempre reflete o entorno paleoambiental no qual as sociedades humanas atuaram; sempre é necessário amostrar fora da área de influência antrópica para conhecer o entorno deposicional natural (não alterado), a maneira em que o sítio se insere nele, e avaliar a intensidade da influência humana nesse sistema (ver tópico 4.2) .

Desde o início da arqueologia moderna, durante o século XVIII, e até meados do século XX, o trabalho arqueológico esteve fortemente vinculado aos princípios da 
estratigrafia geológica (Harris 1991; Renfrew \& Bahn 1993). Alguns autores chegam a sustentar que nunca poderia ter existido uma arqueologia moderna antes do desenvolvimento da geologia, e que a arqueologia é filha desta disciplina (Daniel 1987: 24). Tanto os descobrimentos de John Frere em 1797 e os de Boucher de Perthes em 1837, como as evidências apresentadas por Charles Lyell e John Lubbock (Rapp \& Hill 1998: 5) sobre a antiguidade do homem, contrária ao paradigma bíblico que reinava nesses tempos, sentaram as bases da inevitável cooperação entre ambas as disciplinas.

Não obstante, embora a relação entre arqueologia e estratigrafia se manteve, o desenvolvimento independente que tiveram no século $\mathrm{XX}$ desfavoreceu a interação entre ambas. Foi o sistema arqueoestratigráfico desenvolvido no seio da geoarqueologia o que vinculou novamente ambas as disciplinas (Stein 1990; 1992). Tal sistema refere à estratigrafia elaborada por Gasche \& Tuncha (1983) para o tratamento de depósitos arqueológicos, que adaptou para a análise arqueoestratigráfica as seguintes unidades geológicas: litológica (corpo tridimensional homogêneo caracterizado por qualquer atributo físico do sedimento); etnoestratigráfica (caracterizada por seu conteúdo artefatual); e cronoestratigráfica (caracterizada por sua duração ou suas relações temporais).

Outro sistema estratigráfico elaborado fora do dominio da geoarqueologia, e que se constituiu num dos sistemas mais bem sucedidos mundialmente, foi o elaborado por Edward C. Harris (1991). O autor reconhece que, embora as unidades arqueológicas sigam às leis da estratigrafia geológica, existe um número de unidades próprias da arqueologia que não encontram equivalente no mundo natural e que merecem sua própria nomenclatura e tratamento específico.

A crítica que a classificação elaborada por Harris (1991) recebe da geoarqueologia assinala o fato de ela não se basear em descrição de atributos físicos observados nos sedimentos, senão em critérios genéticos e interpretativos (Stein 1987, 1990). Valendose da interpretação das fontes, dos agentes de transporte e dos mecanismos de deposição dos sedimentos, Harris define as seguintes unidades arqueoestratigráficas: estratos naturais, materiais em situação arqueológica transportados pelo homem ou pela natureza que seguiram às leis de estratificação natural (superposição, horizontalidade original e continuidade original); estratos antrópicos (horizontais ou verticais), materiais transportados e depositados pelo homem que não seguem às leis de estratificação natural; e interfaces (horizontais ou verticais), constituídas pelas superfícies dos estratos 
(leitos ou interfaces de estrato) ou pelas superfícies formadas pela desaparição de uma estratificação anterior (descontinuidades ou elementos interfaciais).

Assim, em termos gerais, existem dois sistemas diferentes de tratamento estratigráfico em sítios arqueológicos: o próprio da geoarqueologia, descritivo como o sistema geológico, desenvolvido para favorecer a intercomunicação entre ambas as disicplinas; e o próprio da arqueologia, interpretativo, elaborado como sistema independente, exclusivo dos depósitos arqueológicos.

Entretanto, o fato de que existam duas maneiras possíveis de considerar a estratigrafia dos sedimentos arqueológicos, a partir de sua interpretação ou de sua descrição, não implica que ambos os sistemas sejam excludentes, mas que se trata meramente de diferentes enfoques que podem ser igualmente aplicados ao mesmo elemento empírico.

Por exemplo, uma unidade litológica (Gasche \& Tunca 1983) pode ser tanto um estrato natural como um estrato antrópico (Harris 1991), sendo que, a unidade litológica é definida em função de atributos físicos descritivos independente do fato da unidade ter sido depositada seguindo as leis da estratificação natural ou não (fato que posteriormente pode ser esclarecido).

Portanto, ambos os sistemas estratigráficos, muitas vezes considerados antagônicos, não são mais do que o complemento um do outro. Sua única diferença, não menor, é o fato de predominar a descrição sobre a interpretação e vice-versa. Sua grande incompatibilidade radica então no peso da abordagem geológica que se esteja dando ao registro, já que em geologia a descrição é fundamental para a inferência de processos e um ponto de partida interpretativo resulta inaceitável.

O sistema de Harris tem a vantagem de ter incluído na nomenclatura arqueoestratigráfica estruturas antrópicas suscetíveis de aparecer em sítios arqueológicos, como muros, calçadas, etc. Entretanto, embora seja extremamente útil no auxílio ao desenho de métodos de escavação de grandes áreas e no registro de feições e estratos verticais e horizontais (através da Matriz Harris), não é apropriado para inferir informação da estratigrafia dos sítios além de mera descrição temporal-seqüêncial das unidades. Este sistema acha-se baseado em critérios geológicos arcaicos, as leis da estratificação natural definidas por Steno no século XVII (Fritz \& Moore 1988), e parte de premisas incorretas sobre a verdadeira diferença entre depósitos naturais e antrópicos. Concentra-se em contextos urbanos e resulta muitas vezes limitado e 
insuficiente, pelo que não consegue dar conta da totalidade de contextos estratigráficos que podem apresentar os sítios arqueológicos.

O sistema geoarqueológico (Gasche \& Tunca 1983), aberto e descritivo, adapta-se facilmente a uma diversidade de situações arqueoestratigráficas. Porém, embora tente aproximar-se da estratigrafia geológica, empresta conceitos sem considerar as diferenças semânticas. Por exemplo, define litologia como qualquer atributo físico, quando a rigor o termo refere ao tipo de rocha (baseado em textura e mineralogia); considerar outros atributos físicos na descrição, como geometria e estrutura, já implica falar de fácies e não de unidades litológicas. Mas o problema fundamental do sistema de Gasche \& Tuncha (1983) é pecar em utilizar uma terminologia geológica antiga que resulta numa abordagem estratigráfica arcaica, inclusive para a geologia, e não acompanha os progressos que a sedimentologia tem conseguido e que podem favorecer enormemente a elaboração de um sistema arqueoestratigráfico.

Atualmente existem vários tipos de descrições arqueoestratigráficas, cada uma com critérios particulares, realizadas em função de objetivos concretos. Este fato não tem contribuído à elaboração de métodos gerais para esta análise que fossem além da mera descrição e interpretação cronológica parcial e macroscópica dos depósitos. No que se refere à arqueoestratigrafia como meio de estudar os processos de formação de sítios, a ênfase tem sido colocada nas descrições de campo e as interpretações parecem saltar diretamente das observações macroscópicas feitas em campo à interpretação cultural.

Interpretações dos perfis arqueoestratigráficos baseadas unicamente nas descrições de campo têm recebido grandes críticas por parte de autores como Barham (1995), que assinala que o registro visual da estratigrafia limita-se a resolução do olho humano $(60 \mu \mathrm{m}$ aprox.) e está restrito ao espectro de luz visível (longitude de onda eletromagnética de 0,4-0,7 $\mu \mathrm{m})$. Portanto, a construção de Matrizes Harris ou de qualquer outro método estratigráfico em campo baseia-se nesta situação particular e resulta numa estratigrafia definida unicamente pelas propriedades visíveis dos perfis. Esta estratigrafia será insuficiente e provavelmente diferente daquela definida a partir de análises no laboratório que registrem os estratos arqueológicos através de um maior espectro de aumentos e longitudes de onda eletromagnéticas.

As descrições em campo devem ser tomadas com extrema precaução na extração de informação interpretativa a partir da apreciação macroscópica dos perfis. Esteja-se tratando de padrões artefatuais originais ou alterados, contextos primários, secundários 
ou terciários (sensu Schiffer 1987) são problemas que somente poderão ser identificados no laboratório após a escavação (Barham 1995).

Atualmente, não existe um método padronizado para a análise dos processos de formação através da arqueoestratigrafia, que estipule uma descrição em campo, respalde-a com uma série de procedimentos analíticos e que relacione tal corpo de informação com processos culturais e naturais passados. Alguns autores têm estabelecido um método deste tipo com ênfase na importância que as análises micromorfológicas têm no estudo dos processos de formação (Courty et al. 1989; Courty 2001; Courty \& Fedoroff 2002). Não obstante, tais métodos geralmente são considerados implícitos e não existe ainda um contexto global que os confirme como padrão.

No próximo capítulo, apresenta-se o método elaborado para o estudo dos processos de formação de depósitos arqueológicos através da análise arqueoestratigráfica, baseado na análise de fácies sedimentológicas (Walker 1983; Anderton 1985) e nas propostas de Stein (1987, 1992, 2001b), Courty (2001) e Courty \& Fedoroff (2002).

A geoarqueologia não necessita confinar-se à valorização dos processos naturais; seus métodos e ferramentas analíticas permitem que esta subdisciplina aborde também os processos de formação culturais e os comportamentos deposicionais. Neste caso, focaliza-se a arqueoestratigrafia para desvendar os processos de formação a partir da adaptação de um método emprestado das geociências: a análise de fácies. 
CAPÍTULO III: ANÁLISE DE FÁCIES EM ARQUEOLOGIA 


\section{1. - Fácies sedimentológicas e fácies arqueológicas}

A conotação processo-resposta do conceito de fácies, versão moderna de um termo que data do século XIX na geologia, é considerada atualmente componente fundamental da sedimentologia. Esta versão moderna do termo começou com os trabalhos pioneiros sobre sistemas deposicionais (Fisher \& McGowen 1969, por exemplo) e alcançou sua maior divulgação com a publicação da obra de Walker (1976 republicada em 1983) Facies Models. Portanto, o conceito de fácies se encontrava bem estabelecido na geologia da década de 1980 quando foram publicados tanto o sistema arqueoestratigráfico de Harris (primeira edição 1979) como o de Gasche \& Tunca (1983). Porém, este conceito não foi nem considerado na época nem posteriormente adicionado ou adaptado. Pode ser apreciado no trabalho de Stein (1987, 1992, 2001b), Brochier (1990, 2002), Brochier et al. (1992), Barham (1995), Gilbertson (1995), Courty (2001), e Courty \& Fedoroff (2002), algumas vezes parcialmente aplicado, outras vezes só mencionado.

Em arqueologia, o termo fácies tem sido utilizado como sinônimo de termos como corte, camada, nível etc., para referir-se basicamente à mesma coisa: unidades identificadas em campo como representantes de um contexto similar de artefatos e definidas segundo qualquer propriedade física e qualquer escala que seja conveniente para a pesquisa (Stein 1987, 1990). O termo fácies tem sido utilizado também para referir-se às unidades litoestratigráficas menores identificadas num sítio (cujo agrupamento conformaria uma camada), representantes de um evento deposicional no tempo (Stein et al. 1992: 97). Em geologia, as chamadas "litofácies" são definidas em função de suas propriedades físicas, químicas e orgânicas, e também representam processos deposicionais individuais, podendo ser agrupadas em associações ou assembléias que caracterizam um ambiente deposicional específico (Miall 1990: 150).

Portanto, as litofácies têm sido usadas em arqueologia, mas como ferramenta essencialmente descritiva. Em sedimentologia, pelo contrário, a descrição não é uma finalidade em si mesma, mas está dirigida a inferir os processos deposicionais que se acham por trás da realidade observada nas seções.

A deficiência fundamental que envolve o uso de litofacies em arqueologia é superada nos trabalhos de Stein et al. (1992), Stein (1996) e Courty (2001). Para estas 
autoras a descrição não representa um objetivo isolado, mas está dirigida à identificação de processos naturais e antrópicos passados.

A análise de microfacies arqueológicas proposta por Courty (2001) é referência fundamental na análise de arqueofácies desenvolvida nesta dissertação. O método proposto pela autora envolve a amostragem das unidades estratigráficas e feições horizontais para realizar estudos micromorfológicos. Este método segue os procedimentos da análise de fácies sedimentológicas, já que envolve descrição em campo, classificação das unidades e estudo sistemático das seções delgadas para entender os agentes naturais e antrópicos atuando conjuntamente nos depósitos arqueológicos.

\section{2. - Análise de arqueofácies}

Em sedimentologia, a análise de fácies envolve a descrição e classificação de um corpo sedimentar, seguidas da interpretação dos seus processos e ambientes de deposição, usualmente sob a forma de um modelo de fácies. A descrição deve ser bem detalhada porque a partir dela se realizam deduções sobre os processos responsáveis pela deposição sedimentar. Estas deduções baseiam-se no entendimento dos processos sedimentares que derivam de estudos teóricos (análogos modernos e exemplos de fácies antigas similares), de laboratório e de campo (Anderton 1985: 36).

Portanto, o termo fácies tem a particularidade de poder ser usado tanto em sentido descritivo como interpretativo. No sentido descritivo, as fácies referem-se a unidades sedimentares que se caracterizam por um conjunto de atributos físicos (como litologia, geometria, estrutura etc.) que as distinguem de outras unidades. No sentido interpretativo, as características descritas podem ser utilizadas na inferência de processos de deposição particulares para cada unidade. Assim, as fácies representam a materialização de um processo sedimentar, e a análise de fácies é entendida como a descrição e classificação de um corpo sedimentar seguida da interpretação dos seus processos e ambientes de deposição (Walker 1983; Anderton 1985; Miall 1990).

Resulta claro que a aplicação da análise de fácies em geologia não segue objetivos semelhantes aos da arqueologia. Primeiro, e fundamentalmente, pelas diferentes escalas 
temporais e espaciais em que trabalham ambas as disciplinas, o que afeta tanto a interpretação dos processos como as reconstruções. Não é objetivo da geoarqueologia a construção de explicações geológicas, mas interpretar os processos antrópicos na escala humana (Stein 1993). E segundo, porque os processos que as duas disciplinas interpretam a partir da estratigrafia são intrinsecamente diferentes. A geologia está interessada em processos naturais relacionados com ambientes de deposição e a arqueologia está interessada na maneira como esses ambientes se relacionam com a formação de sítios e a ocupação humana, valorizando o tipo de atividades humanas no local, sua evolução e intensidade.

Dado que os sedimentos arqueológicos resultam da ação combinada de processos culturais e naturais, estes sedimentos se constituem diferentemente dos sedimentos geológicos precisamente pelo processo antrópico que têm por trás. Por isso, em alguns casos, os sedimentos arqueológicos podem ser fonte de dados paleoambientais, mas também se constituem em importantes recipientes de informação sobre comportamentos humanos pretéritos.

A arqueoestratigrafia de sedimentos arqueológicos envolve o estudo dos produtos sedimentares de processos antrópicos vinculados com culturas passadas que atuaram sobre o meio natural. Esses produtos arqueossedimentares são suscetíveis de ser tratados na seqüência estratigráfica em termos de fácies, tal como se faz em geologia para referir-se aos produtos de processos e ambientes sedimentares passados (ou atuais).

A aplicação de análise de fácies em arqueologia permite vincular novamente os desenvolvimentos teóricos da sedimentologia moderna com o estudo do registro arqueossedimentar. Adotando e adaptando à realidade arqueológica um método de provada utilidade em sedimentologia, amplia-se o espectro de interação entre ambas as disciplinas, o que pode resultar em desenvolvimentos conjuntos em prol da criação de modelos arqueoestratigráficos gerais.

Porém, um cuidado deve ser tomado. No intuito de estabelecer uma linguagem padronizada para a análise do registro arqueossedimentar, todo e qualquer conceito emprestado da geologia deve ser sintaticamente adaptado. Assim como os sedimentos arqueológicos são definidos diferentemente dos sedimentos naturais, a análise de fácies aplicada a seu estudo deve envolver também conceitos específicos, pelo processo responsável pela sua configuração e pelos objetivos próprios desta análise, vinculados ao estudo de sistemas culturais passados. Por isso, no contexto da análise estratigráfica de fácies dos sítios arqueológicos, propõe-se o uso do conceito de arqueofacies, termo 
que pode ser usado indistintamente com "fácies arqueológicas" usado por Brochier (2002).

Contudo, a necessidade de adotar conceitos bem definidos para processos antrópicos e camadas culturais não deve escamotear o fato de que qualquer sítio arqueológico foi parte de um ambiente deposicional, e que em qualquer momento da sua vida foi objeto de processos naturais (Courty 2001: 208).

O detalhamento na descrição de fácies deve ser realizado igualmente em ambas as disciplinas e a procura de análogos modernos é tarefa extremamente difícil para ambas. Em arqueologia, pela dificuldade de tratar com populações humanas passadas, que muitas vezes desaparecem sem deixar vestígio além de seus restos materiais. Em geologia, em virtude do chamado "problema da escala" (análogos modernos são geralmente registro das últimas horas, dias, meses, poucos milhares de anos, enquanto depósitos antigos são o registro de milhões e centenas de milhões de anos), e pelo fato de que os processos não foram necessariamente iguais ao longo do tempo geológico (houve mudanças na cobertura vegetal, na composição da atmosfera, na atividade vulcânica e até nas marés) (Sawakuchi \& Giannini 2006).

Portanto, no nível descritivo e classificatório, a análise de fácies é aplicável em arqueologia na descrição completa e padronizada dos perfis arqueossedimentares e no estabelecimento de relações entre as diferentes fácies identificadas. No nível da interpretação, a elaboração de modelos de arqueofácies deverá ser feita intrinsecamente para cada sítio, com base no que até o momento oferece a literatura arqueoestratigráfica, a qual, na falta de correlatos atuais, deverá ser usada como material de referência.

A análise de arqueofácies implica quatro etapas fundamentais:

1. Descrição detalhada em campo dos perfis arqueoestratigráficos.

2. Caracterização das arqueofácies a través de análise, no laboratório, das suas propriedades (granulometria, composição química, mineralogia, micromorfologia etc.).

3. Estudo da literatura disponível sobre fácies semelhantes às identificadas no sítio.

4. Interpretação das arqueofacies em termos de processos naturais, deposição cultural e comportamentos humanos. 


\subsection{1. - Descrição de arqueofácies}

$\mathrm{Na}$ análise de fácies de bacias sedimentares, a descrição objetiva do sistema é fundamental para alcançar o conhecimento dos processos individuais. Porém, tal descrição não é uma tarefa simples, devido à alta heterogeneidade dos sistemas deposicionais em função das dimensões tempo-espaciais, e ao controle por processos não lineares interagindo a distintos níveis.

A análise de fácies em sedimentologia envolve o registro em campo dos seguintes atributos dos estratos sedimentares: i. litologia (mineralogia e textura); ii. geometria externa; iii. geometria interna (estruturas sedimentares); iv. paleocorrentes; e v. conteúdo biogênico (fósseis, icnofósseis, matéria orgânica) (Selley 1970). Estes parâmetros são os mais utilizados, mas não necessariamente os únicos. A rigor, qualquer propriedade deposicional pode ser usada para descrever, classificar e caracterizar fácies.

Tais atributos são utilizados para definir as fácies sedimentares, mas trabalhando com estratos arqueológicos deve-se lembrar que: a litologia é resultado da deposição de agentes e componentes naturais e antrópicos; a geometria externa não conforma exclusivamente limites geogênicos ou pedogênicos, senão que pode ser também de origem antrópica (Courty 2001: 208); as estruturas sedimentares também refletem a influência da ação do homem na morfologia dos depósitos; paleocorrentes podem não existir ou não serem conhecidas/detectadas; e fósseis podem ser assemelháveis, em certo sentido, ao conteúdo artefactual dos perfis.

Julie Stein (1987; 1992; 2001b) propôs distinguir entre fácies, no perfil, por meio da aplicação de critérios semelhantes aos usados em geologia. A descrição é feita a partir de mudanças nos atributos físicos, como cor, textura, composição e forma do depósito, podendo-se utilizar outras propriedades físicas e diferentes graus de mudança nessas propriedades como critério suficiente para distinguir entre fácies.

Os critérios de definição de fácies em arqueologia são ainda arbitrários (Stein 1992; 2001b), tanto pela complexidade do arranjo que podem apresentar os depósitos arqueológicos como pela conseqüente falta de unanimidade nos critérios de distinção; que podem mudar conforme o tipo de questão levantada nas pesquisas.

Não obstante, a determinação de arqueofácies, pode seguir critérios baseados na sedimentologia (principalmente em sítios pré-históricos), desde que adaptados à 
natureza do registro arqueológico de modo a não incidir em incoerências metodológicas e contra-sensos.

Foi proposta por Giannini et al. (2005) uma adaptação dos critérios utilizados na descrição de fácies sedimentológicas à descrição dos perfis arqueoestratigráficos para trabalhar com os sambaquis do litoral centro-sul de Santa Catarina. Os autores propõem que: no lugar de litologia se descreva o material construtivo e suas propriedades texturais; no lugar da estrutura interna se descrevam as estratificações internas, marcas de estaca, fogueiras, e outras evidências arqueológicas; a geometria externa mantém o mesmo sentido, ou seja, forma e nitidez das superfícies delimitantes de fácies; paleocorrentes é substituída por aspectos posicionais em relação ao sítio e aos elementos da geografia atual e pretérita; e os aspectos biológicos se substituem por evidências humanas diretas, como esqueletos ou covas de sepultamento.

Os autores também propõem a caracterização de fácies como elemento fundamental no reconhecimento de padrões de construção e correlação entre sítios da mesma natureza (neste caso, sambaquis). Tal caracterização vai envolver estudos clássicos em sedimentologia como análises granulométricas, de minerais pesados, petrográficas, isotópicas, faunísticas, botânicas e antracológicas (Giannini et al. 2005).

Devido à alta diversidade de depósitos arqueológicos e à alta variedade dos seus componentes, a descrição de fácies em arqueologia não pode, até o momento, seguir um esquema rígido. O melhoramento da descrição e classificação de arqueofácies deveria se constituir numa prioridade nas pesquisas arqueológicas, segundo Courty (2001: 232), assim como o estabelecimento de uma terminologia padronizada que ajude a unificar as diversas percepções de estratos arqueológicos.

Porém, os indicadores utilizados em sedimentologia aportam um bom ponto de partida na descrição de estratos para análise de arqueofácies. Adaptando estes indicadores à arqueologia, complementados por outros mais em função da natureza do sítio estudado, consegue-se contemplar ao mesmo tempo as realidades antrópica como sedimentar, bem como, potencialmente, a pedológica do depósito arqueológico em questão. 
Assim, na descrição de arqueofácies devem-se registrar no mínimo os seguintes cinco elementos:

1. Composição: incluindo textura, cor e mineralogia.

2. Geometria externa: forma e natureza dos limites entre as unidades arqueossedimentares.

3. Estruturas internas: feições arqueológicas verticais como buracos de estaca, fogueiras, covas de sepultamento etc.

4. Conteúdo orgânico: raízes, matéria orgânica, atividade biológica etc.

5. Componentes antrópicos (artefatos, sepultamentos humanos etc.)

\subsection{2. - Caracterização de arqueofácies}

O primeiro passo envolve a classificação primária das arqueofácies feita a partir das descrições de campo. Propriedades gerais como composição macroscópica e textura permitem reconhecer similaridades e diferenças entre arqueofácies e agrupá-las com base em tais critérios. Posteriormente, a avaliação de tipo e intensidade das mudanças nas propriedades gerais identificadas permite definir possíveis subgrupos (Courty 2001: 215). Uma vez feitas estas classificações macro e mesoscópicas, passa-se à etapa de caracterização baseada numa série de procedimentos analíticos no laboratório que permitirão confirmar, refutar ou refinar as classificações anteriores.

As técnicas de análise escolhidas dependem da natureza do problema e do grau de resolução desejado no estudo. Diversas determinações analíticas podem ser utilizadas na caracterização de arqueofácies: granulometria da fração mineral (ver tópico 4.2.), teor de matéria orgânica e carbonatos, geoquímica, mineralogia, análises isotópicas, arqueofaunísticas, arqueobotânicas, micromorfológicas (ver tópico 4.2.1.), entre outras. Porém, deve-se lembrar que a concepção clássica da geoarqueologia como responsável pelo estudo do registro sedimentar natural dos sítios tem conduzido à aplicação cega dos métodos geológicos no estudo dos sedimentos arqueológicos. As técnicas de análise sedimentológica não são sempre diretamente aplicáveis ao estudo dos sedimentos arqueológicos. Freqüentemente é necessário adaptá-las (Courty \& Miskovsky 2002; Goldberg \& MacPhail 2006), já que as transformações antrópicas introduzem importantes diferenças entre sedimentos ou solos naturais e sedimentos arqueológicos. 
O registro arqueossedimentar não consiste num conjunto de partículas clásticas depositadas naturalmente, que constituem a matriz na qual se produzem os achados arqueológicos. Os sedimentos de natureza arqueológica, por terem sido afetados artificialmente e por possuir informações relevantes à arqueologia (Stein 1985), resultam da ação combinada de processos culturais e naturais, e não estão exclusivamente regidos por fenômenos naturais.

Deve-se levar muito em consideração que nem todas as técnicas geológicas de análise sedimentar são aplicáveis sistematicamente a cada depósito arqueológico. Isto deve-se principalmente ao fato de que geologia e arqueologia, embora lidem igualmente com o registro sedimentar (natural e arqueológico respectivamente), aspiram obter informações radicalmente distintas do estudo dos depósitos. O objetivo geral da análise geológica é o conhecimento dos processos (naturais) a partir do estudo dos seus produtos (Boggs 1987), e tanto as técnicas em si mesmas como a sua aplicação estão viradas a esses fins. Não obstante, em arqueologia, o interesse está em conhecer os comportamentos (humanos) a partir dos seus produtos, e resulta evidente que nem todas as técnicas geológicas, nem seu método padronizado de aplicação, vão aproximar-se eficientemente desses objetivos.

Portanto, as técnicas geológicas existem, contribuem enormemente ao conhecimento do entorno do homem, mas é importante e fundamental que sejam aplicadas e adaptadas corretamente segundo cada caso (Courty \& Miskovsky 2002: 451), para poder resolver os problemas que se estabelecem tanto ao geólogo como ao arqueólogo

Uma vez escolhidas as técnicas de análise para caracterização, todas as amostras coletadas das arqueofácies descritas e identificadas em campo são submetidas aos estudos correspondentes. A partir dos resultados destes estudos classificam-se novamente as arqueofácies em subgrupos em função dos novos dados obtidos no laboratório, comparando-as sistematicamente para identificar suas semelhanças e diferenças. Devido ao fato de que a grande diversidade de processos e produtos relacionados com as atividades humanas ainda não é totalmente conhecida, a classificação comparativa com a totalidade de arqueofácies do sítio vai permitir estabelecer diferenças e similitudes que sejam interpretativamente significativas.

Recentemente uma técnica derivada da ciência do solo está sendo considerada indicador iniludível do caráter antrópico de um solo ou sedimento: a micromorfologia dos depósitos arqueológicos (Hodder 1999: 113; Brochier 2002: 453). Esta técnica 
considera-se básica na caracterização de arqueofácies por constituir o complemento necessário das técnicas sedimentológicas padrão (Courty et al. 1989; MacPhail et al. 1990b; Solé \& Vila 1990; Davidson et al. 1992; Goldberg 1992; Matthews et al. 1997; Evans \& O'Connor 1999; MacPhail \& Cruise 2001; Courty 2001; Courty \& Fedoroff 2002; Courty \& Miskovsky 2002) e apresenta-se como a técnica que fecha o processo de classificação e caracterização porque permite alcançar níveis de refinamento que vão confirmar e aprofundar os critérios definidos macroscopicamente (ver tópico 4.2.1.).

O procedimento apresentado ao longo deste tópico permite construir uma classificação puramente descritiva, que envolve a identificação e o estudo das interações dos processos e comportamentos refletidos nos depósitos. Uma vez que as subdivisões em grupos e subgrupos possam ser vinculadas, então pode-se finalmente interpretar a seqüência de eventos expressada na sucessão vertical de fácies.

\subsection{3. - Interpretação de arqueofácies}

Nos depósitos arqueológicos, tem-se uma associação direta entre culturas específicas e sítios resultantes da sua dinâmica ocupacional e evolutiva. Assim, o conjunto das arqueofácies identificadas num sítio constitui-se como o produto particular dos vestígios ocupacionais da uma sociedade humana pretérita atuando sobre o meio natural, relacionado com as diferentes esferas de seu sistema cultural (produtivo, econômico, social e ideacional), tanto de maneira independente como conjunta.

Desta maneira, as arqueofácies resultam de comportamentos humanos singulares ou de múltiplos componentes, assim como qualquer outro vestígio arqueológico. Como as arqueofácies são eventos únicos, próprios de um sistema cultural e de um sítio especifico, a identificação individual do comportamento que refletem poucas vezes pode ser alcançada. Esse fato, embora resulte assustador à primeira vista, não exclui a possibilidade de poder se aproximar-se desses comportamentos através de um método eficiente inserido em determinada abordagem geoarqueológica.

Em geologia, descrição e caracterização permitem deduzir os processos relacionados com a formação de cada fácies. $\mathrm{O}$ exame das seqüências verticais permite apreciar como os processos mudaram ao longo do tempo, e com base no arranjo espacial das fácies e na presença de atributos diagnósticos de processos específicos, interpreta-se uma associação de fácies que as relaciona genética e ambientalmente. A 
associação de fácies, chave na interpretação dos sistemas deposicionais, é detalhada com base em um modelo de fácies atualista, que usa analogias modernas para poder escolher os elementos que explicam os atributos das fácies e do sistema deposicional interpretado (Walker 1983; Anderton 1985; Reading 1986).

Em arqueologia, descrição e caracterização permitem interpretar a história de vida de todas as partículas que compõem o depósito. Tal reconstrução envolve a determinação da fonte de todos os materiais que compõem as arqueofácies, de todos os agentes de transporte (naturais e antrópicos) para todas as partículas, do ambiente de deposição e das alterações pós-deposicionais que os materiais sofreram (Stein 1985, 2001b). Desta maneira, pretende-se dar conta da realidade genética e diagenética dos constituintes das arqueofácies. Porém, esse não é o objetivo único da análise de arqueofacies, já que, acima de tudo, deve-se lembrar que:

"/... l la arqueología no es la historia de los depósitos arqueológicos, sino una disciplina mediadora para entender o conocer la historia de las comunidades humanas" (Castro et al. 1993: 23).

Portanto, uma vez identificadas as semelhanças e dessemelhanças entre arqueofácies e a partir do seu arranjo espacial relativo, pode ser interpretada na seqüência vertical a associação de arqueofácies. Esta associação expressa a mudança ou permanência de arqueofácies em termos de eventos que podem corresponder a uma mesma intencionalidade deposicional. Nesta etapa utiliza-se tanto a literatura arqueoestratigráfica como a arqueologia experimental, para poder elaborar modelos de arqueofácies que expliquem os seus atributos e os do depósito arqueológico, interpretados em termos de processos naturais, comportamentos humanos e dinâmica da ocupação. 
CAPÍTULO IV: HIPÓTESES E METODOLOGIA 
Os sambaquis do litoral brasileiro são unanimemente considerados estruturas antrópicas construídas pelo grupo humano que lhes outorgou sentido e função dentro do seu sistema social, econômico e político (Gaspar \& DeBlasis 1992; Afonso \& DeBlasis 1994; Figuti \& Klökler 1996; Fish et al. 2000; Klökler 2001). Estas grandes estruturas podem ser consideradas artefatos em si mesmos os quais teriam cumprido diversas funções, conforme proposto por Gaspar \& DeBlasis (1992).

Um artefato define-se pela presença de um atributo, ou conjunto de atributos, resultado da atividade humana e cuja identificação envolve o estudo comparativo com objetos do mesmo tipo (Dunnell 1977). Assim, considerando-se globalmente o fenômeno de sambaquis, pode-se identificar em todos eles uma série de atributos que indiscutivelmente resultaram da ação antrópica. Entre eles, destaca-se sua localização (não devida a processos naturais), sua composição sedimentar (sedimentos arqueológicos constituídos por clastos minerais, bioclastos, restos arqueofaunísticos e artefatuais) e a presência de sepultamentos humanos no interior de vários deles. Porém, os sambaquis apresentam igualmente atributos resultantes de processos naturais, alguns deles já conhecidos, como a presença de camadas concrecionadas de conchas devida à ação de processos diagenéticos, e outros potencialmente a serem descobertos.

Neste trabalho considera-se à camada preta que cobre o sítio Jabuticabeira II como produto de uma ação construtiva deliberada, que resultou no depósito arqueossedimentar observado atualmente na paisagem. Parte-se da hipótese de que tanto a localização como a conformação desta camada e das diferentes unidades arqueossedimentares que a compõem, respondem a uma forma de acumulação conjunta de material sedimentar, antrópico e natural, produto da deposição cultural.

Para seu estudo, aplica-se a análise de arqueofácies, que permite avaliar os processos envolvidos na configuração do sítio ao longo do tempo como resposta à dinâmica da ocupação e à ação de agentes naturais. 


\section{1. - O sítio Jabuticabeira II}

O sítio Jabuticabeira II encontra-se localizado no município de Jaguaruna, Estado de Santa Catarina, sob as coordenadas 22J 699479-6875488 UTM. Suas dimensões compreendem cerca de $350 \mathrm{~m}$ de comprimento, $150 \mathrm{~m}$ de largura e $10 \mathrm{~m}$ de altura, seguindo seu eixo principal a direção NNW/SSE.

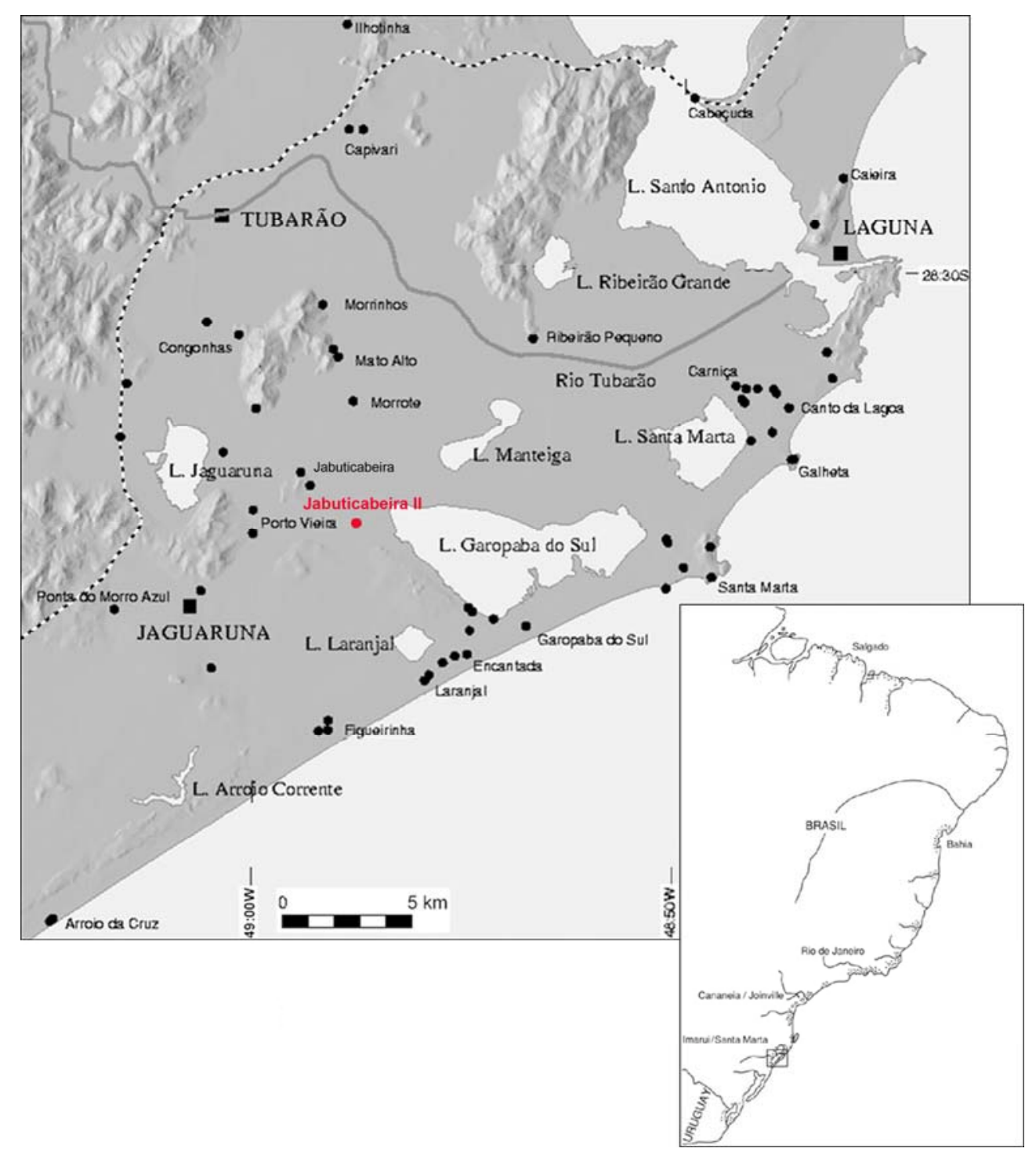

Fig. 1. - Mapa de localização do sítio Jabuticabeira II (adaptado de DeBlasis et al. 2007: 32)

Pela grande quantidade de sepultamentos humanos recuperados no sítio (total estimado de 43.000 sepultamentos), o ritual funerário foi proposto como responsável pela atividade construtiva que, durante quase um milênio deu lugar ao levantamento do sambaqui (Fish et al. 2000; Karl 2000; Gaspar 2000). 
A primeira intervenção no sítio, realizada no projeto "Processos Formativos nos Sambaquis do Camacho, SC" (auxilio à pesquisa temático FAPESP que antecedeu o atualmente em andamento) foi feita no ano de 1997. Nesse momento, abriu-se e limpouse um grande perfil estratigráfico em porção central do sambaqui, nos denominados loci 1 e 2, junto com treze trincheiras. Nos anos subseqüentes, várias trincheiras e áreas de escavação foram abertas nos diversos loci definidos para o sítio, com o intuito de aprofundar os conhecimentos sobre os padrões funerários e os processos de formação.

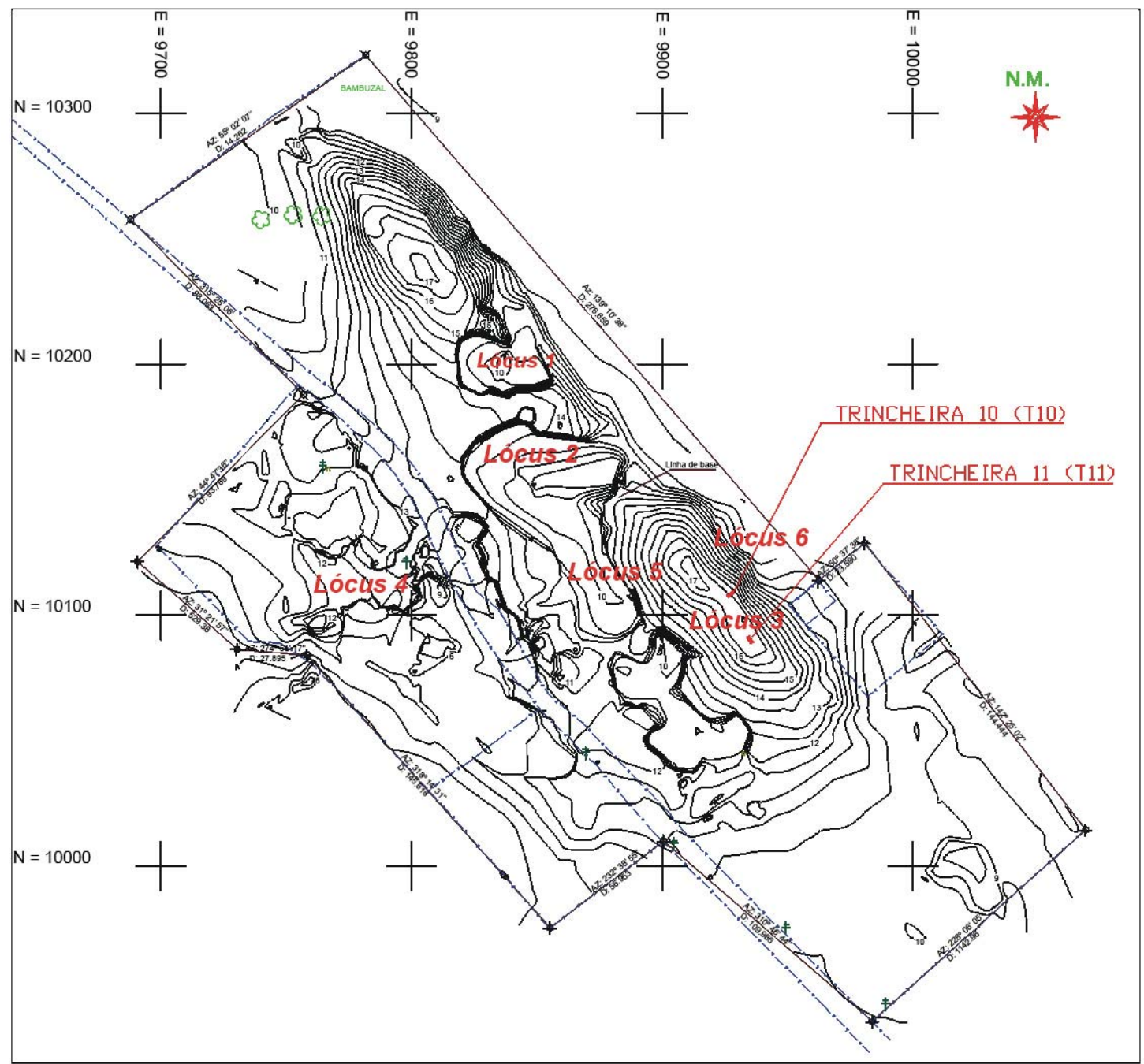

PLANTA PLANIALTIMÉTRICA

ESCALA 1: 1000

$\begin{array}{lllllll}10 & 0 & 10 & 20 & 30 & 40 & 50 \\ \text { ESCALAGRAFICA } & & 100\end{array}$

Fig. 2. - Topografia do sítio Jabuticabeira II com a localização dos diferentes loci e das duas trincheiras abertas na camada preta, estudadas neste trabalho.

A construção do sítio teria começado cerca de 2.900 anos atrás (com base em datação em carvão na trincheira 1: 3.209-2779 anos cal. AP) finalizando hà aproximadamente 1300 anos (datação em osso humano no lócus 3: 1360-1280 anos cal. 
A.P.). No começo de sua construção, o sambaqui achava-se em contexto sedimentar dominado pelo sistema paleolagunar. O sítio provavelmente teria estado localizado originalmente às margens da paleolaguna, cujos recursos faunísticos eram altamente explorados para a subsistência dos sambaquieiros (Klökler 2001). Durante o período de ocupação e elevação do sítio, a margem da laguna foi-se afastando progressivamente conforme o descenso paulatino do nível do mar até chegar às condições atuais, nas quais o sítio dista cerca de $3 \mathrm{~km}$ da borda da atual lagoa de Garopaba do Sul (Kneip 2004).

Nos perfis estratigráficos do sítio, observam-se três grandes camadas estratificadas: uma camada conchífera, na base, intercalada com finos estratos de sedimentos pretos; uma camada de conchas concrecionada diageneticamente; e, cobrindo o conjunto anterio, uma camada preta de espessura decimétrica a métrica (DeBlasis et al. 1998; 2007; Fish et al. 2000; Gaspar et al. 2002; Bendazzoli 2007).

Atualmente, as investigações estão se concentrando nos denominados lócus 2 e 3, caracterizado o primeiro pela presença da camada de conchas e o segundo pela presença da camada preta (DeBlasis et al. 2004). A camada preta do Jabuticabeira II cobre a quase totalidade da grande camada conchífera e sua extensão coincide com a da camada concrecionada (produzida pela ação de processos diagenéticos vinculados com a presença acima da camada preta). A aparição da camada preta tem-se interpretado como uma mudança no regime antrópico de deposição que, 2.000 anos atrás e até o momento final de construção do sambaqui (1.300 anos atrás), substituiu as conchas como material construtivo pelo uso de sedimentos arenosos ricos em carvão, ossos e outros materiais orgânicos (Klökler 2001; DeBlasis et al. 2004).

A presença de sedimentos arqueológicos castanhos a pretos recobrindo sambaquis de núcleo conchífero ou arenoso não é um fenômeno exclusivo do Jabuticabeira II, já que este tipo de camadas também foi descrito para outros sambaquis da região como Encantada III, Mato Alto II, Carniça II e IV, Enseada I e Morrote (Klökler 2001).

Gaspar (1998) assinala que a ocupação dos sítios com esta característica sedimentar foi contínua, e a mudança observada não representa uma descontinuidade social senão que alteração funcional do sítio relacionada com câmbios internos ao sistema social do grupo.

A espessura da camada preta varia ao longo dos diferentes loci, de 0,5 m no lócus 5 até cerca de 2,5 m no lócus 6. No ano de 1999 foram abertas no lócus 3 duas trincheiras, T10 e T11, para poder observar com maior detalhe os aspectos relacionados com a sua formação, funcionalidade e relação com a camada conchífera. Carvões 
coletados nestas trincheiras ofereceram as primeiras datações para a camada preta, 1.862-1622 anos cal. A.P. e 1.864-1534 anos cal. A.P. para a T10 e T11 respectivamente (Fish et al. 2000; DeBlasis et al. 2007).

No primeiro momento de abertura destas trincheiras, as seções verticais apresentaram aparente homogeneidade, mas, conforme o passo do tempo, tornou-se conspícua a grande variedade de unidades arqueossedimentares e feições arqueológicas (marcas de estaca, fogueiras etc.) que as compõem. Acerca da composição macroscópica destas unidades, as pesquisas realizadas até o momento têm identificado o domínio de restos arqueofaunísticos, areia e o que foi identificado como um alto conteúdo de matéria orgânica, assim como pouca presença de conchas em relação à camada conchífera.

O estudo macroscópico estratigráfico realizado por Bendazzolli (2007) corroborou a tese de Klökler \& Gaspar (2004) de que o padrão construtivo observado na camada preta representa continuidade em relação ao padrão interpretado na camada conchífera. Determinadas características mantêm-se constantes em ambas camadas, como unidades arqueossedimentares de formato plano-convexo, presença de estruturas de combustão, bolsões de ossos de peixe, unidades ricas em cinzas e mobiliário funerário associado aos sepultamentos.

A apreciação macroscópica dos perfís permitiu identificar e inferir a presença de dois tipos de unidades arqueossedimentares ni interior da camada preta: uma unidad preta, totalmente queimada, dada sua quantidade de ossos escurecidos por combustão; e outra de cor castanho claro, onde os ossos se apresentam geralmente sem evidências de queima e em maior grau de alteração intempérica (DeBlasis et al. 2004; Giannini et al. 2005; Nishida 2007).

O conteúdo de ossos de peixe dentro dos restos faunísticos de ambas trincheiras é surpreendente. $\mathrm{Na} \mathrm{T} 10$ os ossos conformam aproximadamente $90 \%$ do registro arqueofaunístico, completado pela presença de restos de bivalves, crustáceos, aves, mamíferos, gastrópodes, condrícteos e répteis. A zooarqueologia tem demonstrado que neste sítio a pesca foi uma atividade importante e cotidiana. As espécies melhor representadas são corvinas (Micropogonias furnieri) e bagres (Ariidae), seguido por sargos (Archosaegus probatocephalus), miraguaias (Pogonias chromis) e tainhas (Mugil sp) (Nishida 2007), espécies que, até hoje em dia, são facilmente encontradas nas lagoas da região durante o ano inteiro. A evidência faunística também indicou que a caça de aves e mamíferos foi uma atividade esporádica e de escasso senão nulo papel na 
subsistência do grupo, devido à baixa porcentagem de aparição e a sua reiterada associação com sepultamentos humanos (Klökler 2001; Nishida 2007).

Estudos bioantropológicos respaldaram a evidência faunística, uma vez que baixa freqüência de cáries nos indivíduos enterrados em sambaquis reflete dietas ricas em proteínas e pobres em carboidratos e sugere que estas populações não tinham estabelecido ainda contato econômico com povos agricultores (Okumura \& Eggers 2005: 275).

A camada preta foi interpretada primariamente como possível produto de atividades domésticas. A interpretação baseou-se na alta quantidade de artefatos líticos recuperados e na presença de fogueiras e marcas de estaca, embora o número de sepultamentos permanecesse tão alto quanto nas camadas funerárias da camada conchífera subjacente (Fish et al. 2000).

Estudos zooarqueológicos posteriores concluíram que a camada preta seria uma área ritual e não uma possível área de habitação. $\mathrm{O}$ argumento principal para esta conclusão é a presênça recorrente de estratos ricos em restos arqueofaunísticos formando montículos que recobrem os numerosos sepultamentos humanos; mas outro argumento são a predominância e quase exclusividade de ossos de peixe na sua composição, a associação dos sepultamentos com espécies faunísticas consideradas raras em função da localização e do material mais recorrente no registro (ossos de mamífero, tubarão, raias) e a existência de mobiliário funerário acompanhando os sepultamentos (Nishida 2007).

Novas datações têm-se realizado na camada preta: 1.540-1330 e 1990-1710 anos cal. A.P. para as unidades topo e base da T11 respectivamente; e 1.360-1.280 anos cal A.P. para um sepultamento na área de escavação no lócus 3. As pesquisas realizadas até o momento têm permitido aventar a possibilidade de que o processo de formação cultural da camada preta tenha incluído coleta e transporte de sedimentos paleolagunares da área adjacente ao sítio, aos quais eram adicionados posteriormente os restos arqueofaunísiticos, artefatos e demais restos vinculados à ação antrópica (Giannini et al. 2005; Nishida 2007).

Porém, esta hipótese está únicamente respaldada por critérios intuitivos baseados na semelhança de cor e textura entre depósito paleolagunar e camada preta. Neste trabalho, aprofunda-se mais no conhecimento dos processos de formação desta camada mediante a aplicação da análise de arqueofácies, que permitirá ir além da descrição e caracterização visual macroscópica que até o momento tem se realizada nas pesquisas. 


\section{2. - Sistemas deposicionais da região de localização do sítio}

O litoral centro-sul catarinense, no trecho que vai desde Jaguaruna até Garopaba, apresenta quatro grandes sistemas deposicionais quaternários: lagunar, barra-barreira, planície costeira e eólico (Giannini 1993; 2002)

O sistema lagunar holocênico envolve as lagunas Mirim, Imaruí, Santo Antônio, Santa Marta, Camacho e Garopaba do Sul, todas intercomunicáveis entre si e com o mar, assim como um conjunto de lagos residuais de antigas lagunas. Este sistema foi produto da ação de dois processos mais ou menos simultâneos, resultantes das mudanças no nível relativo do mar, cujo máximo na região conforme Angulo et al. $(1999,2006)$ data de mais de 5.400 anos A.P. Estes processos consistem no crescimento de uma barreira arenosa, com isolamento parcial dos corpos de água a retaguarda, e no afogamento de vales de dissecação previamente escavados em terraços marinhos pleistocênicos. Tal distinção permite a diferenciação entre dois tipos de associações de fácies lagunares, a "baía-laguna" (Santo Antônio, Santa Marta, Camacho e Garopaba do Sul) e a "vale-laguna" (Garopaba, Ibiraquera, Mirim e Imaruí), respectivamente (Giannini 1993, 2002).

O sistema barra-barreira (Giannini 1993, 2002), ou simplesmente barreira (Giannini et al. 2007), com mais de $20 \mathrm{~km}$ de comprimento e até $2 \mathrm{~km}$ de largura, constitui-se de sedimentos arenosos holocênicos depositados sob a ação das ondas através da redistribuição e retrabalhamento ao longo da costa (barra), isolando atrás de si o complexo de lagunas anteriormente mencionado. Este sistema estende-se de Jaguaruna até Laguna (Giannini 1993; 2002).

O sistema planície costeira, que apresenta na região pelo menos duas gerações, uma pleistocênica e a outra holocênica, diferencia-se do anterior por não estar associado geneticamente a corpos lagunares adjacentes e por poder apresentar alinhamentos de cordões litorâneos. O sistema eólico, o de maior extensão, superpõe-se aos sistemas barreira e planície costeira e divide-se em quatro gerações de depósitos eólicos denominadas gerações 1, 2, 3 e 4, em ordem de idade decrescente. A geração eólica 1 é pre-último máximo glacial, a 2 é essencialmente anterior à máxima inundação holocênica, a 3 foi formada quase inteiramente nos últimos três milênios e a 4 
corresponde às dunas ativas ${ }^{3}$ (Giannini 1993, 2002; Giannini \& Suguio 1994; Giannini et al. 2007).
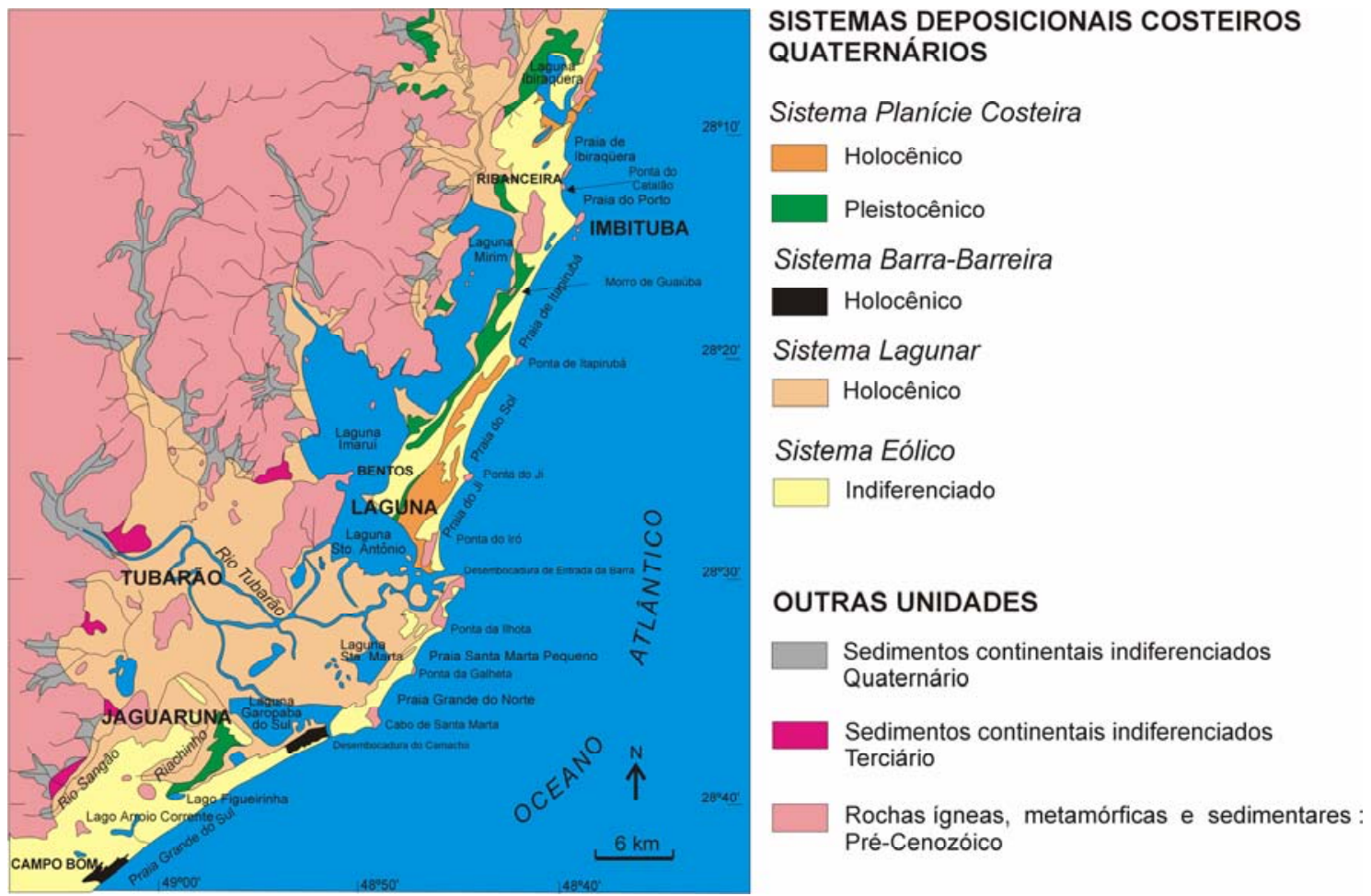

Fig. 3. - Mapa do litoral centro-sul catarinense com a localização dos diferentes sistemas deposicionais costeiros quaternários (Giannini \& Santos 1994).

O sítio Jabuticabeira II encontra-se localizado numa área de intersecção entre depósitos lagunares holocênicos e depósitos eólicos de geração 2 (Giannini et al. 2005). Sobre estes dois tipos de depósitos ocorrem, grosso modo, nas proximidades do sítio, as seguintes unidades de solo, de acordo com o mapa pedológico do Estado de Santa Catarina (escala 1: 250.000): neossolo quartzarênico, solo mineral incipiente de cor castanho claro amarelado desenvolvido sobre areias quartzosas, bem drenado; e organossolo mésico, solo pouco evoluído de cor castanho escuro, com alto conteúdo de matéria orgânica proveniente de acumulações de restos vegetais sob condições de má drenagem (Embrapa Solos 1999).

\footnotetext{
${ }^{3}$ Giannini et al. (2001; 2007) e Sawakuchi (2003) agruparam as gerações eólicas em duas seqüências deposicionais: uma mais antiga (seqüência A) compreendendo a geração eólica 1, e outra mais recente (seqüência B) abrangindo as gerações eólicas 2, 3 e 4. Este agrupamento é reforçado por datações pelo método da luminescência (Sawakuchi 2003; Giannini et al. 2007).
} 


\section{3. - Procedimentos de campo e laboratório}

A análise de arqueofácies elaborada no tópico 3.2. envolve quatro etapas fundamentais no estudo dos processos de formação a partir da arqueoestratigrafia dos sítios. As primeiras duas etapas são as de campo e laboratório, e envolvem tanto a descrição dos perfís como a coleta das respectivas amostras a serem analisadas pelos métodos escolhidos. As últimas duas etapas entram na esfera da interpretação e manejo dos dados, e envolvem a pesquisa bibliográfica sobre arqueofácies semelhantes às identificadas no sítio e a interpretação dos resultados em termos de processos naturais, deposição cultural e comportamentos humanos.

Neste tópico, explicitam-se os procedimentos de campo e laboratório adotados que envolvem as primeiras duas etapas na analise de arqueofácies. Os resultados destes procedimentos e sua discussão serão detalhados no capítulo $\mathrm{V}$, enquanto as informações referentes à última etapa, de interpretação, encontram-se especificadas no capitulo VI.

\subsection{1. - Descrição de arqueofácies}

As seções escolhidas para análise de arqueofácies da camada preta foram a parede leste da T10 (lócus 3), e a parede sul da T11 (lócus 3). Para o levantamento das seções verticais das duas trincheiras analisadas identificaram-se as diferentes unidades arqueossedimentares constituintes. Identificou-se um total de nove unidades na T10 (ver figuras 6 e 7) e quatorze na T11 (ver figuras 4 e 5). As diferentes unidades foram registradas em papel milimetrado e descritas segundo os critérios para descrição de arqueofácies enumerados no tópico 3.2.1. (ver tabelas 1 e 2). 


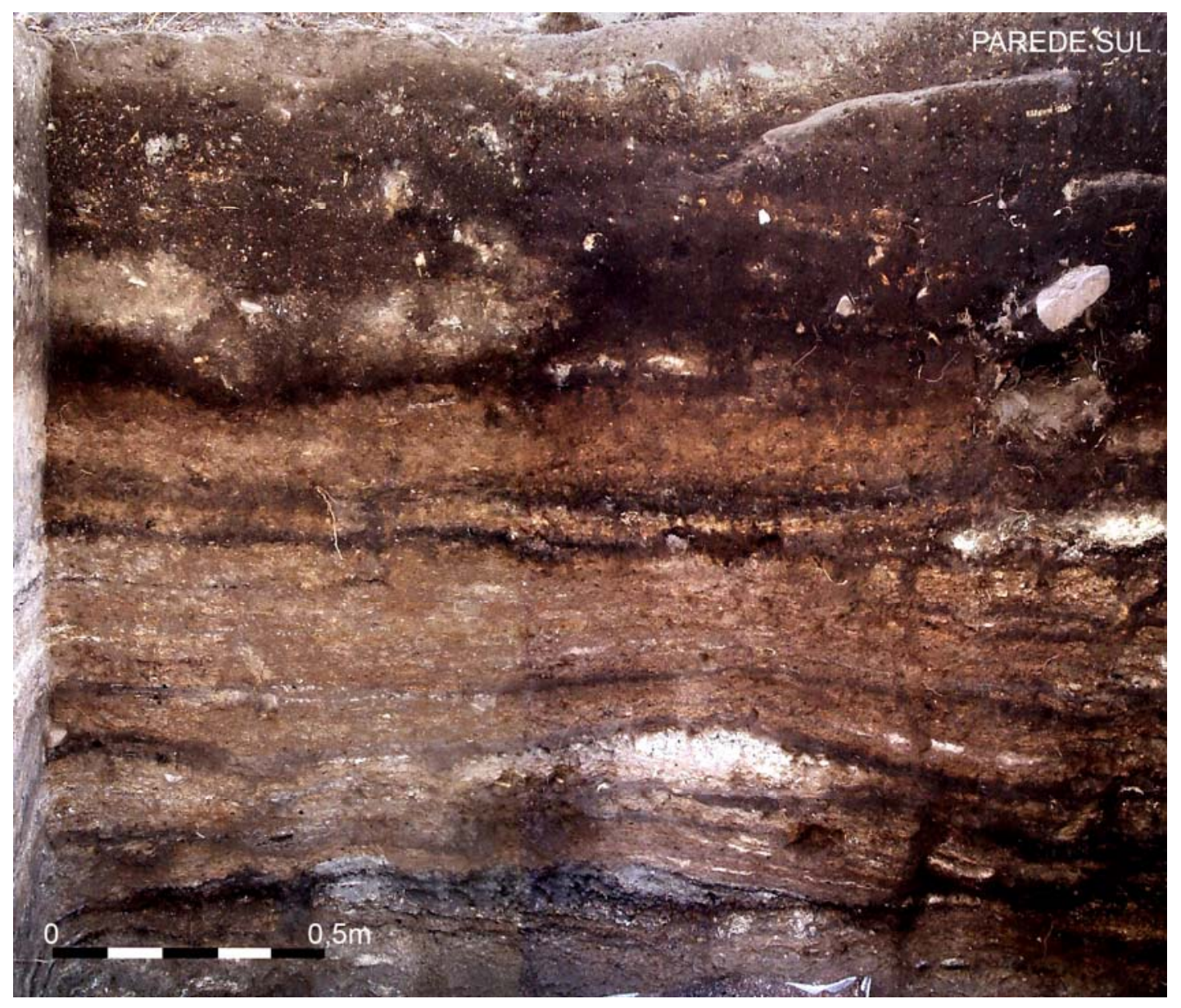

Fig. 4. - Parede sul da T11 (lócus 3). 


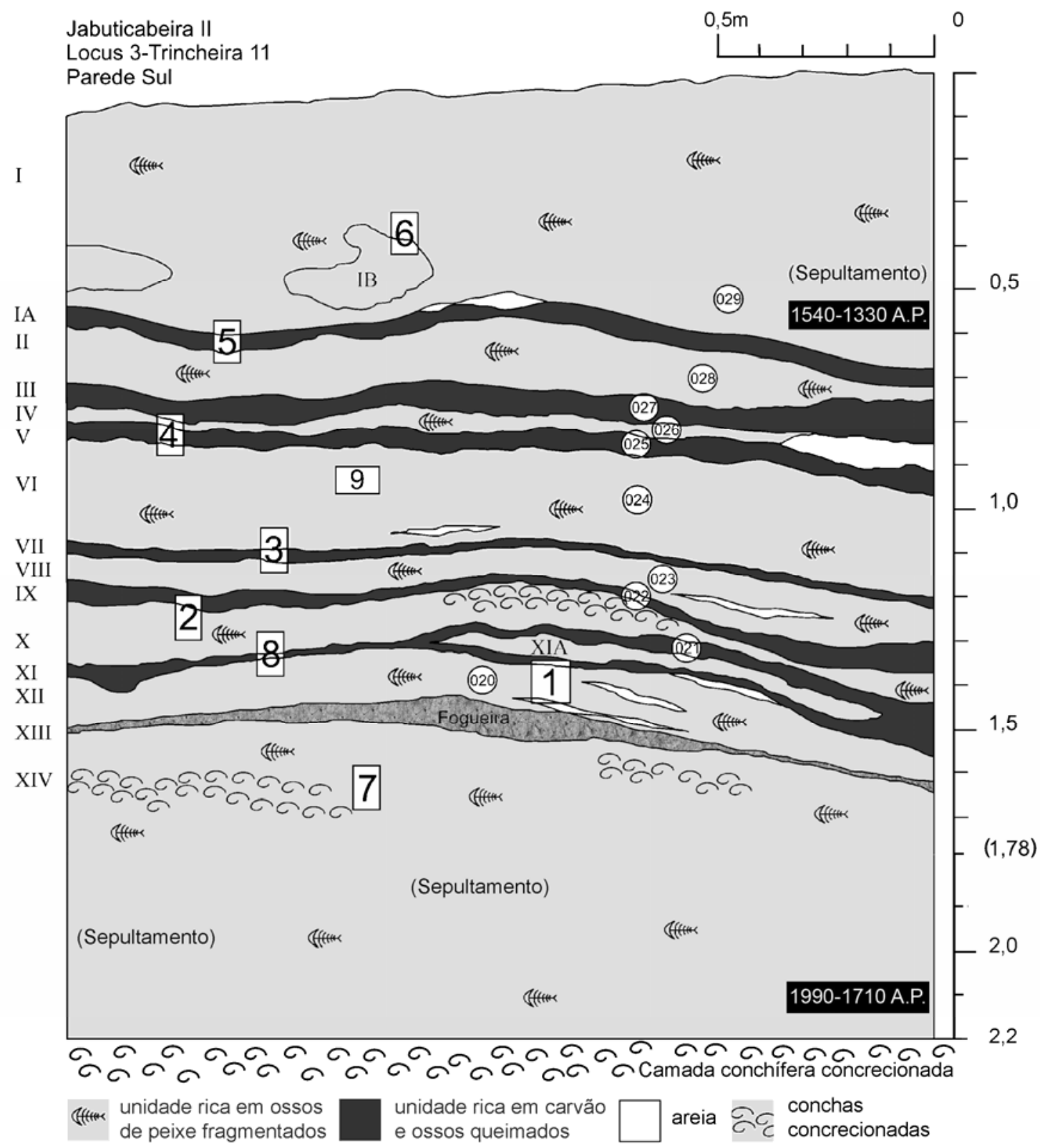

Fig. 5. - Seção estratigráfica vertical da parede sul da T11 (lócus 3). Os círculos numerados de 020 a 029 correspondem as amostragens de sedimento total coletadas. Os retângulos numerados de 1 a 9 correspondem com amostragem para micromorfologia. Três sepultamentos humanos foram recuperados durante a escavação desta seção nas unidades I e XIV. Duas amostras de carvão foram coletadas para datação por carbono 14, uma no contato com a camada conchífera e outra na unidade mais superficial. 


\begin{tabular}{|c|c|c|c|c|c|c|c|c|}
\hline JAB II & T11 & & & & & & & \\
\hline Estratos & Composição & Textura & Transição & Cor & $\begin{array}{l}\text { Estruturas } \\
\text { internas }\end{array}$ & $\begin{array}{l}\text { Compactação e } \\
\text { Consistência }\end{array}$ & $\begin{array}{l}\text { Raízes /M.O./Atividade } \\
\text { Biológica }\end{array}$ & Artefatos \\
\hline I $0-48 \mathrm{~cm}$ & $\begin{array}{l}\text { Heterogênea } \\
\text { Restos } \\
\text { faunísticos } \\
(20 \%) \\
\text { Conchas } \\
\text { Líticos }\end{array}$ & $\begin{array}{l}\text { Franco- } \\
\text { argilo-siltoso }\end{array}$ & Abrupto/Liso & $\begin{array}{l}\text { 10YR } 3 / 2 \text { very } \\
\text { dark greyish brown }\end{array}$ & & Firme-levemente duro & Raízes: muitas/ médias & Líticos \\
\hline $\begin{array}{l}\text { II } \\
48-61 \mathrm{~cm}\end{array}$ & $\begin{array}{l}\text { Heterogênea } \\
\text { Restos } \\
\text { faunísticos } \\
(15 \%) \\
\text { Conchas }\end{array}$ & $\begin{array}{l}\text { Franco } \\
\text { argiloso }\end{array}$ & $\begin{array}{l}\text { Abrupto/ } \\
\text { ondulado }\end{array}$ & $\begin{array}{l}5 Y R 3 / 2 \text { dark } \\
\text { reddish brown }\end{array}$ & & Muito friável-suave & Raízes: muitas/ finas & Líticos \\
\hline $\begin{array}{l}\text { III } \\
61-67 \mathrm{~cm}\end{array}$ & $\begin{array}{l}\text { Restos } \\
\text { faunísticos (5\%) } \\
\text { Carvão }\end{array}$ & $\begin{array}{l}\text { Franco } \\
\text { argiloso }\end{array}$ & $\begin{array}{l}\text { Abrupto/ } \\
\text { ondulado }\end{array}$ & 10YR 2/1 black & & Friável-suave & Raízes: comum/ finas & \\
\hline $\begin{array}{l}\text { IV } \\
67-70\end{array}$ & $\begin{array}{l}\text { Heterogênea } \\
\text { Restos } \\
\text { faunísticos } \\
(30 \%) \\
\text { Conchas }\end{array}$ & $\begin{array}{l}\text { Franco } \\
\text { argiloso }\end{array}$ & Abrupto/ liso & $\begin{array}{l}\text { 10YR } 4 / 2 \text { dark } \\
\text { greyish brown }\end{array}$ & & Muito friável-suave & Raízes: comum/ finas & \\
\hline $\begin{array}{l}V \\
70-74 \mathrm{~cm}\end{array}$ & $\begin{array}{l}\text { Restos } \\
\text { faunísticos (7\%) } \\
\text { Carvão }\end{array}$ & $\begin{array}{l}\text { Franco } \\
\text { argiloso }\end{array}$ & Abrupto/ liso & 10YR 2/1 black & & Friável/ suave & Raízes: comum/ finas & \\
\hline
\end{tabular}

Tab. 1. - Descrição para análise de arqueofácies na T11. 
Continuação Tabela 1.

\begin{tabular}{|c|c|c|c|c|c|c|c|c|}
\hline Estratos & Composição & Textura & Transição & Cor & $\begin{array}{l}\text { Estruturas } \\
\text { internas }\end{array}$ & $\begin{array}{l}\text { Compactação e } \\
\text { Consistência }\end{array}$ & $\begin{array}{l}\text { Raízes /M.O./Atividade } \\
\text { Biológica }\end{array}$ & Artefatos \\
\hline $\begin{array}{l}\text { VI } \\
74-98 \mathrm{~cm}\end{array}$ & $\begin{array}{l}\text { Heterogênea } \\
\text { Restos } \\
\text { faunísticos (40\%) } \\
\text { Cinzas } \\
\text { Lentes de areia }\end{array}$ & $\begin{array}{l}\text { Franco- } \\
\text { argiloso }\end{array}$ & Abrupto/ liso & $\begin{array}{l}\text { 10YR } 4 / 2 \text { dark } \\
\text { greyish brown }\end{array}$ & & Muito friável/ suave & Raízes: poucas/ finas & \\
\hline $\begin{array}{l}\text { VII } \\
98-100 \mathrm{~cm}\end{array}$ & $\begin{array}{l}\text { Restos } \\
\text { faunísticos (3\%) } \\
\text { Cinzas } \\
\text { Carvão }\end{array}$ & $\begin{array}{l}\text { Franco } \\
\text { argiloso }\end{array}$ & Abrupto/ liso & $\begin{array}{l}\text { 7.5YR } 3 / 1 \text { very } \\
\text { dark grey }\end{array}$ & & Friável/ suave & Raízes: poucas/ finas & \\
\hline $\begin{array}{l}\text { VIII } \\
100-106 \mathrm{~cm}\end{array}$ & $\begin{array}{l}\text { Heterogênea } \\
\text { Restos } \\
\text { faunísticos (50\%) } \\
\text { Cinzas } \\
\text { Carvão } \\
\text { Lentes de areia }\end{array}$ & $\begin{array}{l}\text { Franco- } \\
\text { argiloso }\end{array}$ & Abrupto/ liso & $\begin{array}{l}\text { 10YR } 3 / 2 \text { very dark } \\
\text { greyish brown }\end{array}$ & & Muito friável/ suave & Raízes: poucas/ finas & Líticos \\
\hline $\begin{array}{l}\text { IX } \\
106-111 \mathrm{~cm}\end{array}$ & $\begin{array}{l}\text { Restos } \\
\text { faunísticos (5\%) } \\
\text { Cinzas } \\
\text { Carvão }\end{array}$ & $\begin{array}{l}\text { Franco- } \\
\text { argiloso }\end{array}$ & Abrupto/ liso & $\begin{array}{l}\text { 10YR } 3 / 1 \text { very dark } \\
\text { grey }\end{array}$ & & Friável/ suave & Raízes: poucas/ finas & \\
\hline $\begin{array}{l}X \\
111-125 \mathrm{~cm}\end{array}$ & $\begin{array}{l}\text { Heterogênea } \\
\text { Restos } \\
\text { faunísticos (50\%) } \\
\text { Conchas } \\
\text { concrecionadas } \\
\text { Cinzas }\end{array}$ & $\begin{array}{l}\text { Argila } \\
\text { arenosa }\end{array}$ & Abrupto/ liso & $\begin{array}{l}\text { 10YR } 4 / 2 \text { dark } \\
\text { greyish brown }\end{array}$ & & Muito friável/ suave & Raízes: poucas/ finas & Líticos \\
\hline
\end{tabular}


Continuação Tabela 1.

\begin{tabular}{|c|c|c|c|c|c|c|c|c|}
\hline Estratos & Composição & Textura & Transição & Cor & $\begin{array}{l}\text { Estruturas } \\
\text { internas }\end{array}$ & $\begin{array}{l}\text { Compactação e } \\
\text { Consistência }\end{array}$ & $\begin{array}{l}\text { Raízes /M.O./Atividade } \\
\text { Biológica }\end{array}$ & Artefatos \\
\hline $\begin{array}{l}X I \\
125-128 \mathrm{~cm}\end{array}$ & $\begin{array}{l}\text { Restos } \\
\text { faunísticos (7\%) } \\
\text { Cinzas } \\
\text { Carvão }\end{array}$ & $\begin{array}{l}\text { Argila } \\
\text { arenosa }\end{array}$ & Abrupto/ liso & $\begin{array}{l}\text { 7.5YR } 3 / 1 \text { very } \\
\text { dark grey }\end{array}$ & & Friável/ suave & Raízes: poucas/ finas & \\
\hline $\begin{array}{l}\text { XIA } \\
125-128 \mathrm{~cm}\end{array}$ & $\begin{array}{l}\text { Heterogênea } \\
\text { Restos } \\
\text { faunísticos } \\
(50 \%) \\
\text { Conchas } \\
\text { Cinzas }\end{array}$ & $\begin{array}{l}\text { Argila } \\
\text { arenosa }\end{array}$ & $\begin{array}{l}\text { Abrupto/ } \\
\text { ondulado }\end{array}$ & $\begin{array}{l}\text { 10YR 4/2 dark } \\
\text { greyish brown }\end{array}$ & & Friável/ solto & Raízes: poucas/ finas & \\
\hline $\begin{array}{l}\text { XII } \\
128-139 \mathrm{~cm}\end{array}$ & $\begin{array}{l}\text { Heterogênea } \\
\text { Restos } \\
\text { faunísticos } \\
(30 \%) \\
\text { Cinzas } \\
\text { Lentes de areia }\end{array}$ & $\begin{array}{l}\text { Argila } \\
\text { arenosa }\end{array}$ & Abrupto/ liso & 10YR 4/3 brown & & $\begin{array}{l}\text { Muito friável/ suave quase } \\
\text { solto }\end{array}$ & Raízes: poucas/ finas & \\
\hline $\begin{array}{l}\text { XIII } \\
139-141 \mathrm{~cm}\end{array}$ & $\begin{array}{l}\text { Restos } \\
\text { faunísticos } \\
\text { queimados } \\
(50 \%) \\
\text { Carvão } \\
\text { Cinzas }\end{array}$ & Siltoso & $\begin{array}{l}\text { Abrupto/ } \\
\text { ondulado }\end{array}$ & $\begin{array}{l}\text { 10YR 4/2 dark } \\
\text { greyish brown }\end{array}$ & $\begin{array}{l}\text { Fogueira sobre o } \\
\text { mound que } \\
\text { cobre um } \\
\text { sepultamento }\end{array}$ & Duro & Raízes: algumas/ finas & \\
\hline $\begin{array}{l}\text { XIV } \\
141-178 \mathrm{~cm}\end{array}$ & $\begin{array}{l}\text { Restos } \\
\text { faunísticos } \\
\text { queimados } \\
(50 \%) \\
\text { Cinzas } \\
\text { Conchas } \\
\text { concrecionadas }\end{array}$ & Siltoso & Base perfil & $\begin{array}{l}\text { 10YR } 4 / 2 \text { dark } \\
\text { greyish brown }\end{array}$ & $\begin{array}{l}\text { Estrato base de } \\
\text { pequeno mound } \\
\text { com fogueira no } \\
\text { centro. }\end{array}$ & Duro & Raízes: algumas/ finas & \\
\hline
\end{tabular}



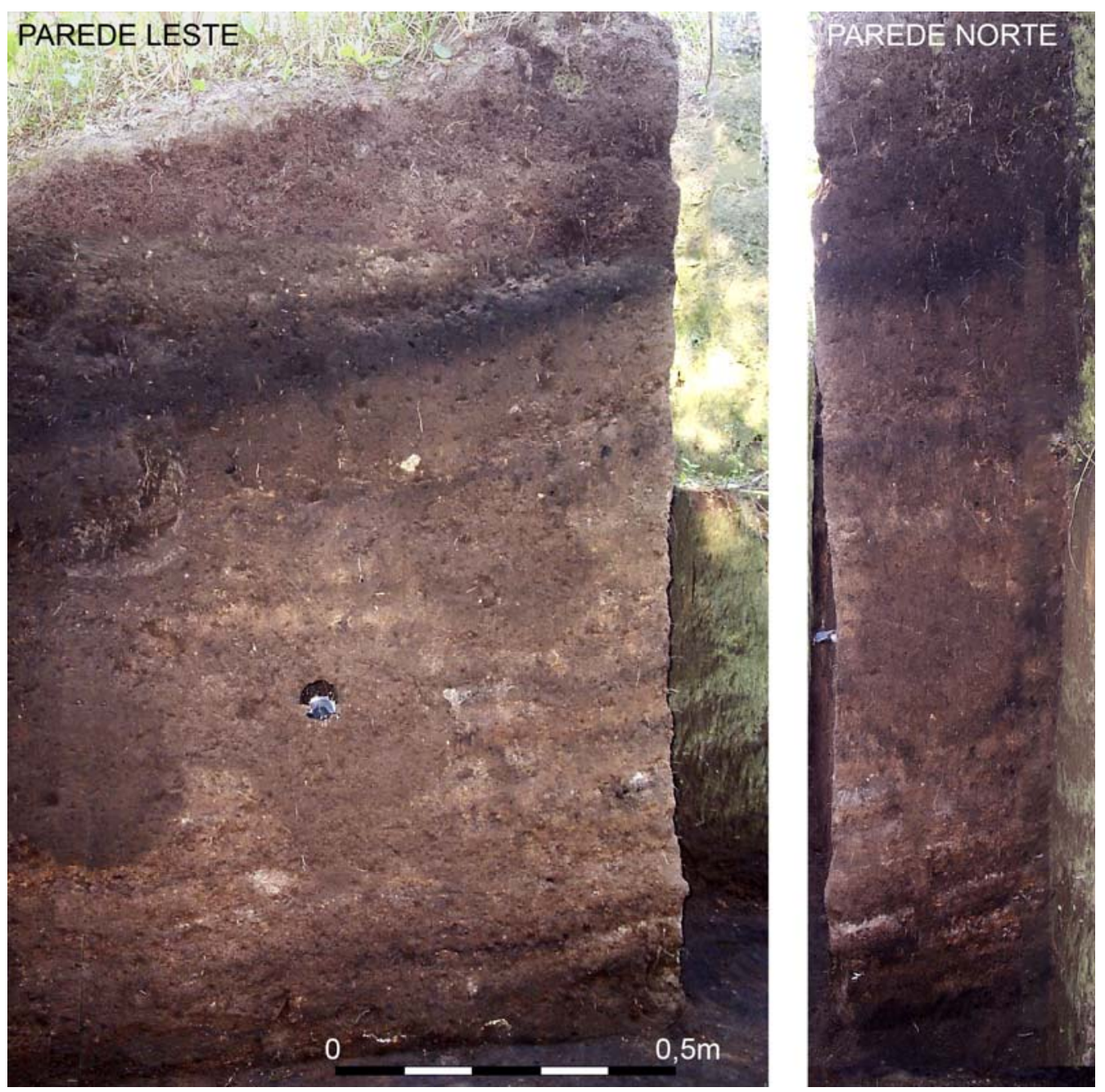

Fig. 6. - Paredes leste e norte da T10 (lócus 3). 


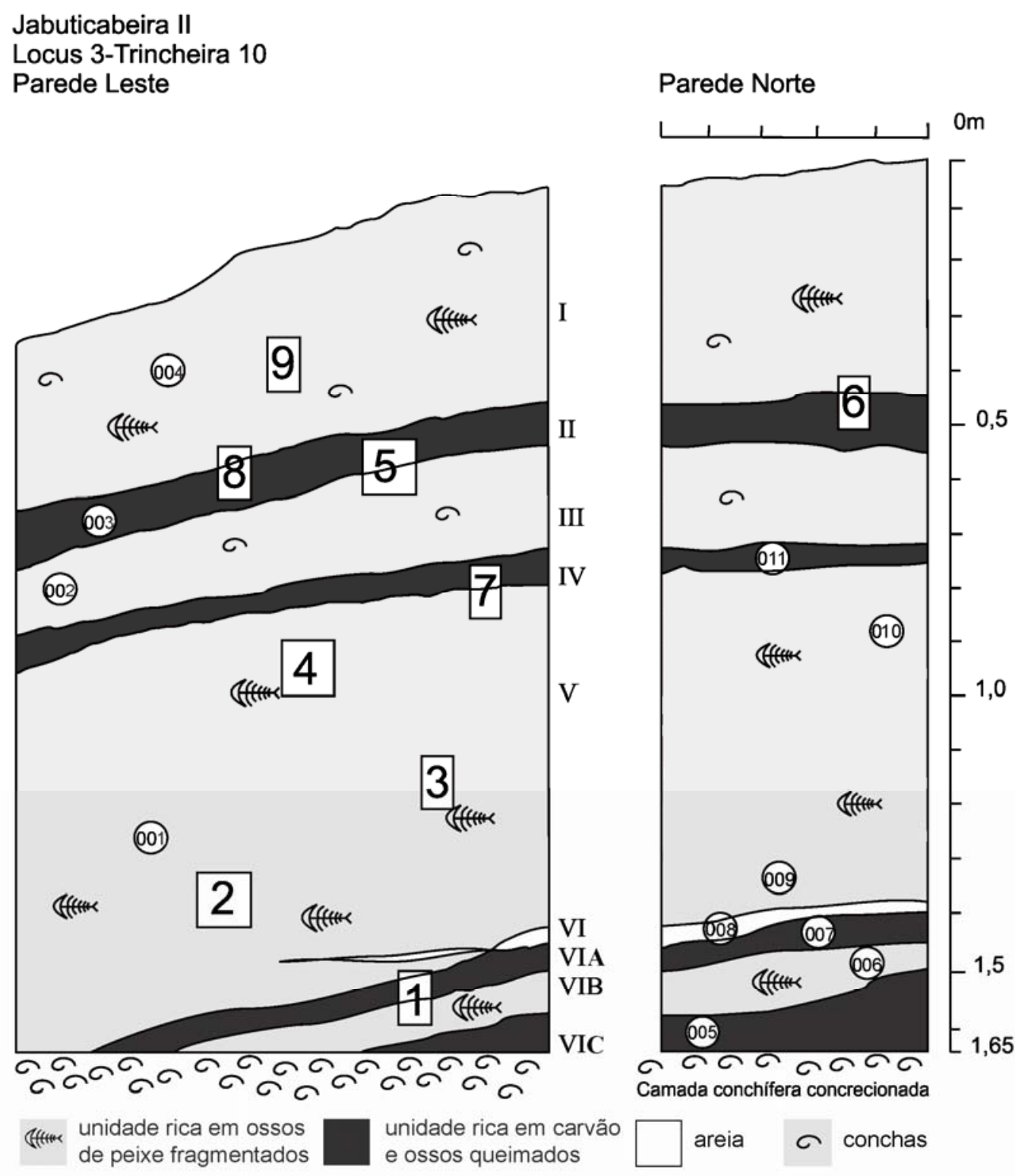

Fig. 7. - Seção estratigráfica vertical das paredes leste e norte da T10 (lócus 3). Os círculos numerados de 001 a 011 correspondem às amostras de sedimento total coletadas. Os retângulos numerados de 1 a 9 correspondem a amostragens para micromorfologia. 


\begin{tabular}{|c|c|c|c|c|c|c|c|c|}
\hline JAB II & T10 & & & & & & & \\
\hline Estratos & Composição & Textura & Transição & Cor & $\begin{array}{l}\text { Estruturas } \\
\text { internas }\end{array}$ & $\begin{array}{l}\text { Compactação e } \\
\text { Consistência }\end{array}$ & $\begin{array}{l}\text { Raízes /M.O./Atividade } \\
\text { Biológica }\end{array}$ & Artefatos \\
\hline $\begin{array}{l}\text { I } \\
0-42 \mathrm{~cm}\end{array}$ & $\begin{array}{l}\text { Heterogênea } \\
\text { Restos faunísticos } \\
(7 \%) \\
\text { Conchas }\end{array}$ & $\begin{array}{l}\text { Franco } \\
\text { siltoso }\end{array}$ & Cortante/Liso & $\begin{array}{l}7.5 Y R \text { P/1 very } \\
\text { dark grey }\end{array}$ & & Levemente duro-friável & $\begin{array}{l}\text { Raízes: muitas/ médias. } \\
\text { Atividade biológica }\end{array}$ & \\
\hline $\begin{array}{l}\text { II } \\
42-52 \mathrm{~cm}\end{array}$ & Ossos de peixe (2\%) & $\begin{array}{l}\text { Franco } \\
\text { siltoso }\end{array}$ & Cortante/ liso & 7.5YR 2.5/1 black & & Muito friável-suave & Raízes: comum/ finas & \\
\hline $\begin{array}{l}\text { III } \\
52-72 \mathrm{~cm}\end{array}$ & $\begin{array}{l}\text { Heterogênea } \\
\text { Restos faunísticos } \\
(5 \%) \\
\text { Conchas } \\
\text { Lítco }\end{array}$ & $\begin{array}{l}\text { Franco } \\
\text { siltoso }\end{array}$ & $\begin{array}{l}\text { Cortante/ liso } \\
\text { Difuso (parede } \\
\text { Leste) }\end{array}$ & $\begin{array}{l}\text { 10YR } 3 / 1 \text { very } \\
\text { dark grey }\end{array}$ & & Muito friável-suave & Raízes: muitas/ finas & Litico \\
\hline $\begin{array}{l}\text { IV } \\
72-78 \mathrm{~cm}\end{array}$ & $\begin{array}{l}\text { Heterogênea } \\
\text { Restos faunísticos } \\
(5 \%)\end{array}$ & $\begin{array}{l}\text { Franco } \\
\text { argiloso }\end{array}$ & $\begin{array}{l}\text { Claro/ liso } \\
\text { Difuso (parede } \\
\text { leste) }\end{array}$ & 10YR $2 / 1$ black & & Muito friável-suave & Raízes: comum/ finas & \\
\hline $\begin{array}{l}\mathrm{V} \\
78-140 \mathrm{~cm} \\
\text { (parede Leste) } \\
78-138 \mathrm{~cm} \\
\text { (parede Norte) }\end{array}$ & $\begin{array}{l}\text { Heterogênea } \\
\text { Restos faunísticos } \\
(30 \%) \\
\text { Lentes de areia } \\
\text { Lentes escuros (10YR } \\
2 / 1 \text { black) de limite } \\
\text { abrupto/ ondulado } \\
\text { Lentes claros (10YR } \\
4 / 3 \text { dark greyish } \\
\text { brown) de limite } \\
\text { gradual/ irregular } \\
\text { Lentes de cinzas } \\
\text { (10YR } 4 / 2 \text { dark } \\
\text { greyish brown) de } \\
\text { limite abrupto/ liso }\end{array}$ & $\begin{array}{l}\text { Argila } \\
\text { arenosa }\end{array}$ & $\begin{array}{l}\text { Cortante/ } \\
\text { ondulado }\end{array}$ & $\begin{array}{l}\text { 10YR 2/2 dark } \\
\text { brown }\end{array}$ & $\begin{array}{l}\text { Feições } \\
\text { circulares } \\
\text { (unidade VA) } \\
7.5 Y R \text { 3/2 dark } \\
\text { brown } \\
\text { Ossos de peixe } \\
(2 \%)\end{array}$ & Friável/ suave & Raízes: muitas/ finas-médias & \\
\hline
\end{tabular}

Tab. 2. - Descrição para análise de arqueofácies na T10 
Continuação Tabela 2.

\begin{tabular}{|c|c|c|c|c|c|c|c|c|}
\hline Estratos & Composição & Textura & Transição & Cor & $\begin{array}{l}\text { Estruturas } \\
\text { internas }\end{array}$ & $\begin{array}{l}\text { Porosidade e } \\
\text { Consistência }\end{array}$ & $\begin{array}{l}\text { Raízes /M.O./Atividade } \\
\text { Biológica }\end{array}$ & Artefatos \\
\hline $\begin{array}{l}\mathrm{VI} \\
140-145 \mathrm{~cm} \\
\text { (parede leste) } \\
138-140 \mathrm{~cm} \\
\text { (parede Norte) }\end{array}$ & $\begin{array}{l}\text { Restos faunísticos } \\
(3 \%)\end{array}$ & Areia & Abrupto/ liso & $\begin{array}{l}\text { 10YR 6/2 light } \\
\text { brownish grey }\end{array}$ & & Solta & Raízes: poucas/ finas & \\
\hline $\begin{array}{l}\text { VIA } \\
145-150 \mathrm{~cm} \\
\text { (parede Leste) } \\
140-145 \mathrm{~cm} \\
\text { (parede Norte) }\end{array}$ & $\begin{array}{l}\text { Restos faunísticos } \\
(2 \%)\end{array}$ & $\begin{array}{l}\text { Franco- } \\
\text { argiloso }\end{array}$ & Abrupto/ liso & 7.5YR 2.5/1 black & & Friável/ levemente duro & Raízes: poucas/ finas & \\
\hline $\begin{array}{l}\text { VIB } \\
150-157 \mathrm{~cm} \\
\text { (parede Leste) } \\
145-150 \mathrm{~cm} \\
\text { (parede Norte) }\end{array}$ & $\begin{array}{l}\text { Heterogênea } \\
\text { Restos faunísticos } \\
(25 \%)\end{array}$ & $\begin{array}{l}\text { Argila- } \\
\text { arenosa }\end{array}$ & Cortante/ liso & $\begin{array}{l}\text { 7.5YR } 3 / 3 \text { dark } \\
\text { brown }\end{array}$ & & Muito friável/ suave & Raízes: poucas/ finas & \\
\hline $\begin{array}{l}\text { VIC } \\
157-165 \mathrm{~cm} \\
\text { (parede Leste) } \\
150-165 \mathrm{~cm} \\
\text { (parede Norte) }\end{array}$ & $\begin{array}{l}\text { Restos faunísticos } \\
(2 \%)\end{array}$ & $\begin{array}{l}\text { Franco- } \\
\text { argiloso }\end{array}$ & Base perfil & 7.5YR 2.5/1 black & & Friável/ levemente duro & Raízes: poucas/ finas & \\
\hline
\end{tabular}


A totalidade de unidades arqueossedimentares identificadas para cada seção vertical foram amostradas para posterior caracterização, no laboratório, quanto aos seguintes atributos: distribuição granulométrica, teor de matéria orgânica, porcentagem de ossos e carbonatos, mineralogia da fração argila, composição química multielemental e micromorfologia, inlcuindo estudos por microscopia eletrônica de varredura. Para isso, foram coletadas amostras de sedimento total e de blocos inalterados de cada unidade identificada em ambas as trincheiras.

\subsection{2. - Amostragem na área de controle}

Embora a análise de arqueofácies seja um método desenhado para entender os processos de formação de um determinado sítio arqueológico, sua ação em termos de observação e amostragem não pode se restringir unicamente ao sítio em questão. $\mathrm{Na}$ caracterização de arqueofácies, torna-se fundamental entender o impacto físico-químico induzido pela ação humana no local e que resulta na formação de sedimentos arqueológicos de valor essencial para inferir processos culturais. Portanto, deve-se ampliar o campo de atuação e de amostragem, incluindo dentro da pesquisa também a área circundante ao sitio que não sofreu os efeitos da ação antrópica (Cook \& Heizer 1965; Eidt 1973; 1985; Sjoberg 1976; Stein 1985; Butzer 1989; Bjelajac et al. 1996; Rapp \& Hill 1998).

Junto com o registro e amostragem dos perfis das trincheiras 10 e 11 foram também abertos sete pontos de sondagem na área de controle externa ao sítio, que visaram cobrir os quatro flancos cardinais do sítio e abranger as diferentes unidades sedimentares e pedológicas que o rodeiam.

Abriram-se sondagens de 1x1x1 m na planície a Norte, Noroeste, Sudoeste e Sul do sítio. Nessas sondagens, foram registrados as fácies naturais identificadas e coletadas amostras de sedimento total e blocos inalterados principalmente das fácies superiores. 


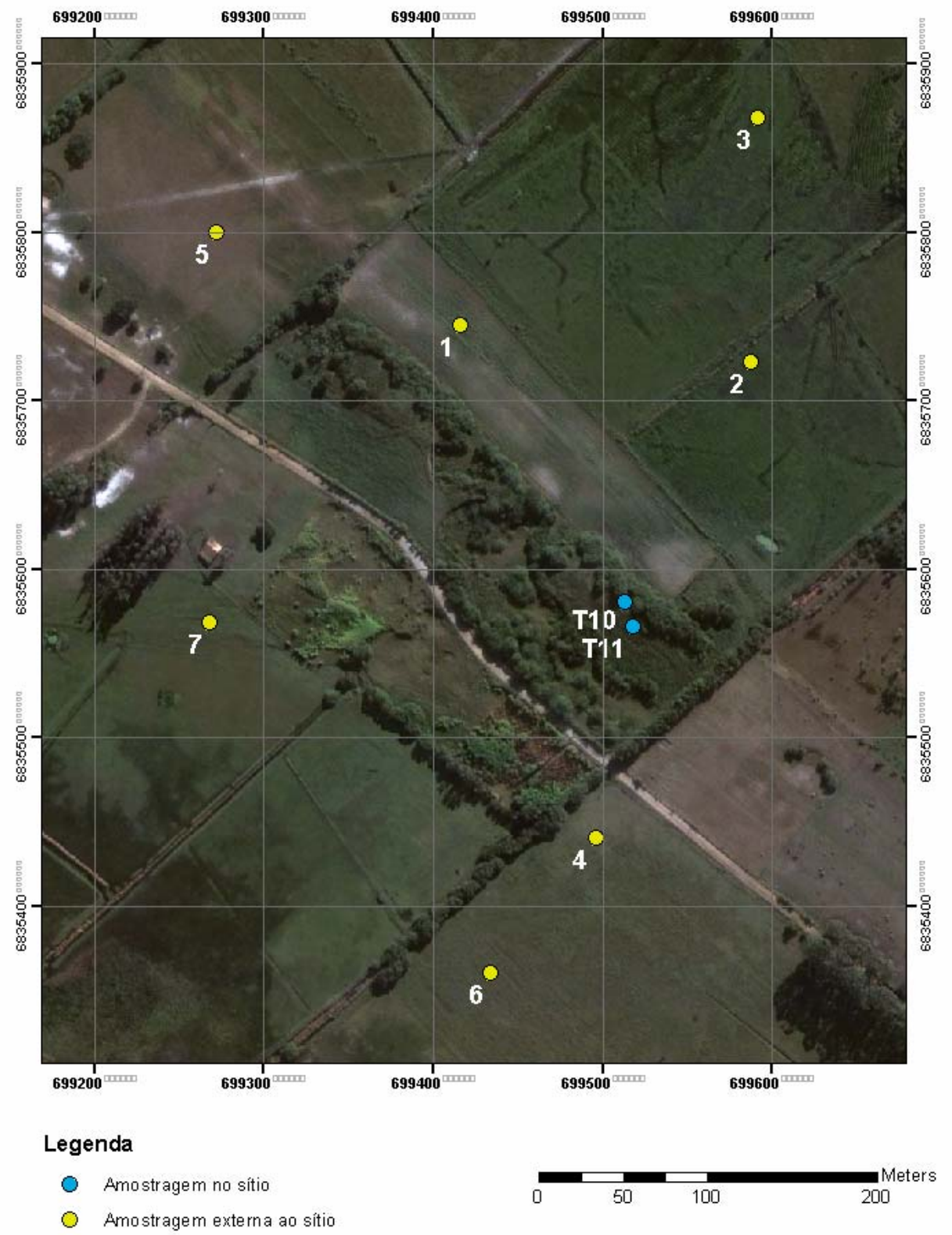

Fig. 8. - Imagem de satélite do sítio com a localização das duas trincheiras analisadas (T10 e T11) e dos sete pontos de amostragem externa ao sítio (área de controle). 


\subsection{3. - Análises granulométricas}

O objetivo das análises granulométricas realizadas neste trabalho estão dirigidas à caracterização física das arqueofácies para comparações com os sistemas deposicionais da região de localização do sítio, e para avaliar os aportes antrópicos de materiais clásticos, como tem sido proposto por Jacques Brochier (2002). Segundo este autor, no meio arqueológico (ou meios naturais onde os aportes são baixos ou nulos) tem sido mostrado que as distribuições granulométricas são melhor descritas pela "lei da moagem” de Rossin ${ }^{4}$ que pela lei normal (curva de Gauss). Isso deve-se ao fato da ação humana acumular na zona habitada uma importante massa de materiais sedimentares, $\mathrm{o}$ que resulta em distribuições granulométricas que não se ajustam aos modelos naturais de transporte e deposição de sedimentos; a tal ponto que a precisão do ajuste da distribuição em estudo com os dois tipos de distribuições teóricas (Gauss e Rossin) pode ser utilizada para descrever o grau de alteração ou evolução de um sedimento (Kittleman 1964). Quanto menos preciso é o ajuste com a distribuição de Gauss, mais forte seria, segundo o autor, a probabilidade de estar em presença de uma acumulação antrópica.

Foi determinada a granulometria por pipetagem (fração silte e argila) e peneiramento (fração areia e cascalho) nas amostras da T11 e nas sete sondagens realizadas na área de controle. As análises foram realizadas no Laboratório de Sedimentologia do Instituto de Geociências (GSA-IGc/USP).

$\mathrm{Na}$ caracterização dos sedimentos naturais, as amostas foram mantidas intactas, sem sofrer qualquer tipo de ataque para remoção de matéria orgânica (MO) ou carbonatos de cálcio $\left(\mathrm{CaCO}_{3}\right)$. A determinação dos teores destes elementos foi realizada em amostras separadas mediante o método de perda de massa por oxidação com peróxido de hidrogênio $\left(\mathrm{H}_{2} \mathrm{O}_{2}\right)$ e por ataque com ácido clorídrico $(\mathrm{HCl}$ a $10 \%)$ para as porcentagens de $\mathrm{MO}$ e $\mathrm{CaCO}_{3}$ respectivamente.

Para caracterização física das arqueofacies, foi elaborado um método que tenta minimizar a alteração artificial das amostras para evitar o conseqüente falseamento dos resultados da granulometria. A alta fragilidade dos carvões e dos ossos que compõem estes sedimentos impede a aplicação das técnicas tradicionais de desagregação

\footnotetext{
${ }^{4}$ Vários estudos mostraram que os materiais produzidos por fraturamento de rochas cristalinas, por exemplo, têm distribuição granulométrica similar ao produto da moagem de materiais rochosos. Tais produtos de fraturamento mecânico têm a característica de apresentar um excesso de fragmentos finos (Suguio 1980: 19).
} 
(separação das partículas de silte e argila). Para tanto, a dispersão foi realizada usando três gramas de agente defloculante (pirofosfato de sódio $\mathrm{Na}_{2} \mathrm{P}_{2} \mathrm{O}_{7}$ ) e a desagregação foi feita com agitador mecânico por poucos minutos, evitando-se o passo de desagregação em almofariz com pistilo. O procedimento de elutriação foi eliminado, já que a própria deslamagem provocaria a flotação e a perda das partículas de densidade menor, como os carvões e os ossos. Assim, as areias foram separadas usando uma malha de 0,062 $\mathrm{mm}$ colocada sobre um béquer, onde a solução da amostra foi vertida e lavada com jato de água destilada. O lavado foi em seguida recolhido no béquer e colocado na proveta para pipetagem e o retido na malha foi filtrado e seco em estufa a $60^{\circ} \mathrm{C}$, para posterior peneiramento.

Para utilizar a granulometria como parâmentro de comparação entre sedimentos arqueológicos e sedimentos naturais, buscou-se descartar o componente orgânico e inorgânico bioclástico dos sedimentos arqueológicos e naturais para assim poder relacionar ambos os grupos de amostras em base à fração areia de origem terrígena.

Deste modo, as amostras dos sedimentos arqueológicos e dos solos e sedimentos naturais foram atacadas primeiro com $\mathrm{HCl}(50 \%)$ a frio, para eliminar o $\mathrm{CaCO}_{3}$ e os ossos, e depois com água oxigenada $\left(\mathrm{H}_{2} \mathrm{O}_{2}\right)$ em chapa quente a $90^{\circ} \mathrm{C}$, para retirar a $\mathrm{MO}$. Em seguida as amostras foram desagregadas em almofariz com pistilo de borracha e os carvões presentes na fração areia (escolhida para comparação) foram intencionalmente fragmentados até alcançar à fração fina (silte/ argila) ${ }^{5}$. Somente a fração areia do material resistente restante, supostamente dominado por terrígenos silicáticos, principalmente quartzo, foi peneirado e sua granulometria determinada.

As distribuições granulométricas obtidas por este método na camada preta, e aquelas de sedimentos naturais determinadas pelo método convencional, foram utilizadas para determinação de parâmetros estatísticos (assimetria, desvio padrão, diâmetro médio e curtose) calculados pelo método analítico dos momentos de Pearson, utilizando o programa MOMENTOS.xls.

Considera-se que o tratamento com $\mathrm{H}_{2} \mathrm{O}_{2}$ e $\mathrm{HCl}$ pode ser utilizado na determinação da porcentagem aproximada de $\mathrm{MO}$, e de carbonatos mais fosfatos (basicamente representados por ossos). O carvão contido nas amostras não interfere na

\footnotetext{
${ }^{5} \mathrm{O}$ conteúdo de carvão em solos ou sedimentos pode ser determinado, mas para isso devem-se aplicar procedimentos que vão além das análises propostas para este estudo (ver White \& Hannus 1981; Glaser et al. 1998; 2000). Neste trabalho as partículas maiores de carvão serão estudadas qualitativa e quantitativamente nas seções delgadas, que permitem tanto a análise da sua granulometria como sua descrição morfológica.
} 
estimativa das concentrações destes elementos por dois motivos: primeiro, porque ele é estável na $\mathrm{H}_{2} \mathrm{O}_{2}$ a temperatura ambiente, sem importar sua granulometria ou tempo de reação (White \& Hannus 1981; Kirchmann \& Springob 2002); e segundo porque o $\mathrm{HCl}$ também não reage com o carvão, e não apresenta propriedades oxidantes a temperaturas da ordem de $100^{\circ} \mathrm{C}$; seria necessário aquecer as amostras a altas temperaturas para ativar o carvão e começar a induzir sua decomposição ${ }^{6}$ (White \& Hannus 1981: 367).

\subsection{4. - Análise química multi-elemental}

A ocupação de uma área por uma comunidade humana modifica as proriedades físicas de um solo ou sedimento e introduz mudanças e incrementos na concentração dos elementos químicos; tais mudanças podem ser detectadas mediante o uso de métodos que identifiquem as concentrações de certos elementos considerados chave (Cook \& Heizer 1965; Stein 1984; Eidt 1985; Barba et al. 1995; Middleton \& Price 1996; Mejía \& Barba 1998; Rapp \& Hill 1998; Fernandez et al. 2002; Parnell et al. 2002; Middleton 2004).

Atividades humanas em áreas restritas efetivamente induzem um intemperismo diferencial, geram resíduos líquidos e sólidos que podem impactar intensivamente o terreno, e dão lugar a um sedimento arqueológico profundamente afetado (Middleton \& Price 1996: 681).

A caracterização multi-elemental é escolhida neste trabalho como ferramenta para identificar modificações antrópicas nos solos e sedimentos. Com técnicas analíticas modernas como a Espectrometria de Emissão Atómica por Plasma de Acoplamento Induzido (ICP-AES) ou a Fluorescência de Raios-X (FRX) (método utilizado neste trabalho), pode-se determinar uma ampla variedade de elementos simultaneamente, rapidamente e com um custo relativamente baixo, em grande quantidade de amostras (Linderholm \& Lundberg 1994: 305; Middleton \& Price 1996: 674; Middleton 2004: 48).

\footnotetext{
${ }^{6} \mathrm{O}$ método de combustão em seco (loss on ignition), muito utilizado na determinação de teores de M.O. e $\mathrm{CaCO}_{3}$ em sítios arqueológicos (Dean 1974; Stein 1984) não foi utilizado neste estudo pela alta quantidade de carvões contidos nas amostras. Este método, que alcança temperaturas de $500^{\circ} \mathrm{C}$ para determinar o teor de M.O. e $1100{ }^{\circ} \mathrm{C}$ para determinar a porcentagem de $\mathrm{CaCO}_{3}$, tem a desvantagem de superestimar os resultados em amostras que contêm carvão na sua composição (Schmidt \& Noack 2000: 786).
} 
Todas as amostras da T11 (020 a 029, ver figura 5), localizada no sambaqui, foram preparadas para análise química multi-elemental, assim como aquelas provenientes da fácies lamosa (horizonte $\mathrm{A}$ ) dos pontos 3,5 e 6 e da fácies turfosa do ponto 7, estas em sedimentos na área de controle (ver figs. 15, 17, 18 e 19). Os pontos 3, 6 e 7 da área de controle foram escolhidos para comparação por terem apresentado as maiores concentrações de $\mathrm{MO}$ e a maior semelhança visual macroscópica com os sedimentos da camada preta arqueológica; em contraposição, o ponto 5 foi escolhido pela sua dessemelhança com a camada preta, principalmente em termos de cor e textura.

A determinação de elementos maiores, menores e traço foi realizada no Laboratório de Fluorescência de Raios-X do Instituto de Geociências (DMG-IGc/USP). As concentrações de carbono e nitrogênio totais foram determinadas com auxilio de um analisador LECO no Laboratório de Química e ICP-OES do mesmo instituto (DMGIGc/USP).

\subsection{5. - Difratometria de raios-X}

A mineralogia da fração argila também foi determinada tanto nos estratos arqueológicos como na área de controle mediante Difratometria de Raios-X. Este estudo permite conhecer a composição mineralógica da fração argila e contrastar assim os aportes ou modificações do material fino que caracterizam os sedimentos arqueológicos trabalhados, tanto em termos de processos naturais de intemperismo como em termos de modificação antrópica induzida pela ocupação.

Para preparação das amostras utilizadas nesta análise foi extraída uma alíquota adicional da fração argila durante o processo de pipetagem que foi vertida sobre uma lâmina de vidro até secar completamente. As análises foram realizadas no Laboratório de Difratometria de Raios-X do Instituto de Geociências (GMG-IGc/USP).

\subsection{6. - Micromorfologia de depósitos arqueológicos}

Nos últimos anos, tem aparecido nos meios de divulgação científica uma grande quantidade de artigos de pesquisas arqueológicas que utilizam a micromorfologia de solos na resolução de ampla diversidade de questões arqueológicas. Estas questões estão principalmente relacionadas à identificação e caracterização de pisos de ocupação 
vinculados a diversas atividades dentro dos sítios (Gé et al. 1993; Goldberg \& Whitbread 1993; Gebhardt \& Langohr 1999; Courty 2001; MacPhail et al. 2004), ao reconhecimento de atividades agrícolas (MacPhail et al. 1990a) ou pesqueiras (Simpson et al. 2000), aos processos de formação e transformação de sítios (Simpson et al. 1996; Matthews et al. 1997; Simpson et al. 1999; Creemengs 2005), às mudanças paleoambientais neles registradas (Karkanas 2002) e aos tipos de combustíveis utilizados nos depósitos (Simpson et al. 2003), entre outros diversos temas de estudo.

A micromorfologia não é uma ciência em si mesma, mas uma ferramenta de pesquisa que permite o estudo de amostras intactas de solos e sedimentos com a ajuda de técnicas de microscopia (Delvigne 1998). Foi originalmente formulada por Kubiena (1938) na década de 1930, e sua primeira aplicação em arqueologia remonta à década de 1950 com os trabalhos de Cronwall (1958) e Darlymple (1958) que demonstraram a utilidade da micromorfologia em estudos paleoambientais e geocronológicos. Não obstante, foi na década de 1980 que floresceram as aplicações desta técnica em arqueologia com a publicação dos primeiros trabalhos de autores como Goldberg (1979; 1983), MacPhail (1983) e Courty (1983).

A micromorfologia responde a uma ampla variedade de questões geoarqueológicas que não se alcançam através das técnicas de laboratório padrão (Courty et al. 1989; MacPhail et al. 1990b; Solé \& Vila 1990; Davidson et al. 1992; Goldberg 1992; Matthews et al. 1997; Evans \& O'Connor 1999; MacPhail \& Cruise 2001; Courty 2001; Courty \& Fedoroff 2002; Courty \& Miskovsky 2002). Apresenta-se como a técnica capaz de proporcionar o nexo campo-laboratório (Solé \& Vila 1990; Solé 1991), como a ferramenta que habilita a observação direta tanto da realidade qualitativa descrita em campo (através da descrição das seções verticais) como dos dados físicos e composicionais quantitativos obtidos no laboratório.

A análise na escala microscópica constitui etapa básica na caracterização de arqueofacies. Permite alcançar níveis de refinamento que vão confirmar e aprofundar os critérios definidos macroscopicamente em campo ${ }^{7}$, assim como os resultados das análises feitas no laboratório. A micromorfologia se ocupa tanto da descrição microscópica dos componentes que formam os solos e sedimentos, como da maneira em

\footnotetext{
7 Em geologia, uma situação similar é observada com as rochas carbonáticas que requerem necessariamente da descrição em seções delgadas para análise de fácies, devido a sua alta susceptibilidade aos processos diagenéticos e ao fato de que a informação necessária para sua correta descrição (litologia e presença de fósseis) não pode se conseguir ao olho nu (Miall 1990: 28).
} 
que estes se relacionam entre si e das hierarquias existentes entre os diferentes processos atuantes nos depósitos (processos deposicionais, pós-deposicionais, naturais e antrópicos).

Este aspecto da micromorfologia resulta de extrema importância em arqueologia, já que permite, a partir da configuração que apresentam os sedimentos, alcançar o conhecimento microscópico da história deposicional e pós-deposicional dos depósitos arqueológicos (Courty et al. 1989; Simpson et al. 1999; Courty 2001; MacPhail \& Cruise 2001; Karkanas 2002), o que ulteriormente aproxima a um melhor conhecimento sobre os processos de formação de sítio.

Atualmente, a micromorfologia de solos e sedimentos arqueológicos encontra-se numa conjuntura de trajetórias divergentes, herdadas de duas disciplinas das ciências da Terra, a pedologia e a sedimentologia. Porém, diferentemente da micromorfologia de solos e da petrografia sedimentar, interessadas pela dinâmica das organizações pedológicas e sedimentares respectivamente, a micromorfologia de depósitos arqueológicos integra ambas as abordagens outorgando uma dimensão original aos estudos micromorfológicos. Ela vincula-se às transformações de solos e sedimentos pelas atividades humanas, também definidas como "antropização dos sedimentos", elemento quase sempre ignorado pela sedimentologia e vinculado exclusivamente às práticas agrícolas na pedologia (Courty \& Fedoroff 2002).

O conceito de antropização dos sedimentos foi acunhado pela arqueologia comportamental (Schiffer 1987), na qual os processos culturais são definidos grosseiramente no nível sedimentar como as ações físicas exercidas pelos humanos no local de ocupação. Três processos básicos foram definidos para explicar a formação de toda unidade arqueossedimentar: acumulação, transformação e redistribuição. Porém, estes processos são insuficientes para explicar a diversidade de manifestações antrópicas registradas nos sedimentos arqueológicos.

A antropização de solos e sedimentos não se reconhece através de traços inequívocos, como no caso dos artefatos. As atividades humanas nos sedimentos operam através de processos muito similares, senão iguais, àqueles controlados por fatores naturais, seguem as mesmas leis físicas definidas para os agentes naturais, porque o homem pode também ser considerado um agente natural (Courty \& Fedoroff 2002). Por isso, as feições micromorfológicas propriamente antrópicas são somente definidas na etapa de interpretação, em oposição às organizações que resultam dos 
processos naturais (relativos à sedimentação e aos processos pedológicos) (Courty 2001; Courty \& Fedoroff 2002).

Para coleta no campo de cada amostra destinada à micromorfologia, um bloco de material sedimentar é esculpido cuidadosamente no perfil. Uma vez esculpido, encaixase nele o recipiente de amostragem (que neste caso foram caixas de papelão de 10x6x4 cm) e efetua-se a extração do bloco, com a mínima alteração possível das amostras. Uma vez extraídos, os blocos são embrulhados com filme de PVC e fita crepe, sempre indicando sua orientação (topo e base) com uma seta.
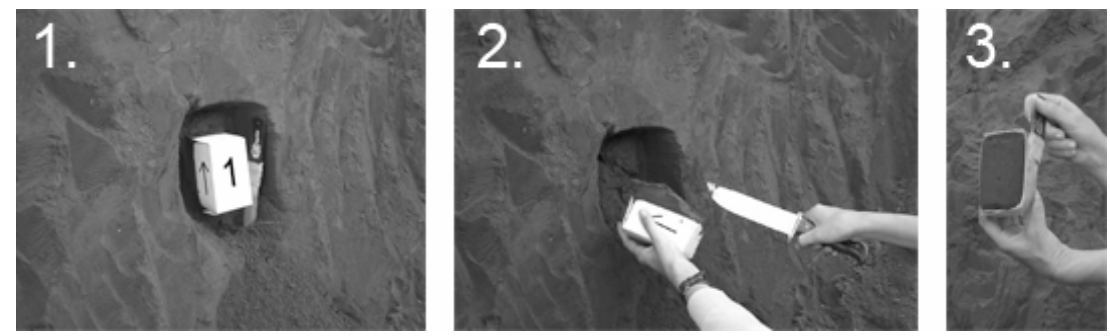

Fig. 9. - Procedimento de extração de blocos inalterados de um perfil estratigráfico.

A escolha das posições de amostragem na camada preta fez-se de modo a abranger a totalidade das mudanças estratigráficas observadas nas seções trabalhadas (Courty et al. 1989; Davidson et al. 1992; MacPhail \& Cruise 2001; Goldberg \& MacPhail 2003), com ênfase nos limites entre arqueofácies e subfácies. Foram coletados nove blocos de material inalterado das duas trincheiras analisadas. Porém, somente cinco blocos da T10 e oito na T11 completaram o processo de preparação.
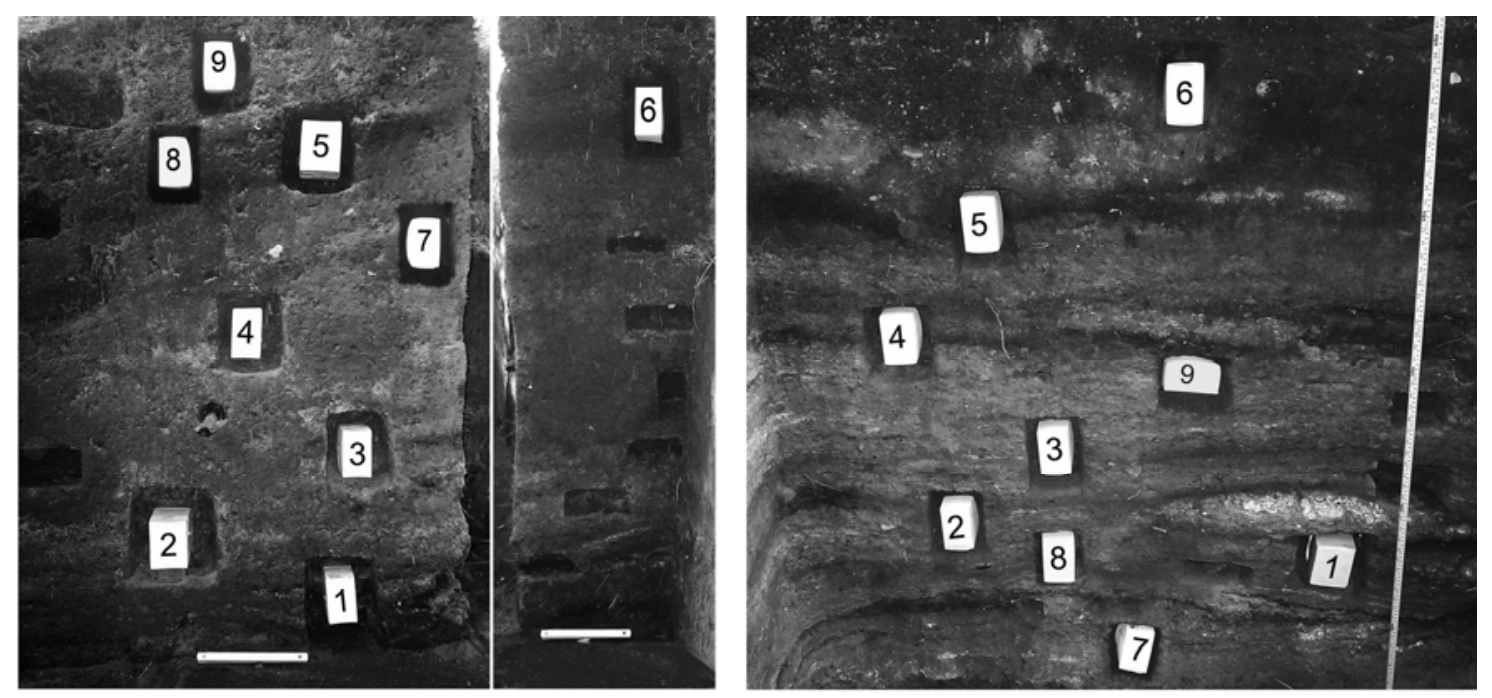

Fig. 10. - Posição dos blocos inalterados para amostragem micromorfológica na T10 (esquerda) e T11 (direita). 
As análise micromorfológica foi realizada ao microscópio óptico de luz polarizada em seções delgadas especialmente preparadas. A descrição das lâminas foi realizada segundo roteiros sugeridos por Stoops (2003), Bullock et al. (1985) e Courty et al. (1989). A tradução dos termos do inglês ao português foi realizada segundo Stoops (1986). O limite superior da fração fina (ou micromassa) foi estabelecido para o total das lâminas em $10 \mu \mathrm{m}$.

\subsection{7. - Microscopia eletrônica de varredura}

Análise de microscopia eletrônica de varredura (MEV) foram realizadas com a finalidade de aprofundar os conhecimentos sobre a natureza das diferentes micromassas identificadas na seção delgada, principalmente em termos de composição química. Estas análises foram realizadas no Laboratório de Microscopia Eletrônica de Varredura do Instituto de Geociências (GSA-IGc/USP).

Três seções delgadas de amostras da camada preta provenientes da T10 foram submetidas à análise ao sistema MEV-EED. Amostras brutas de fragmentos de osso e carvão foram estudadas no mesmo equipamento. As análises foram realizadas com sensores de elétrons secundários (SE), para obtenção de imagens de micro-relevo, de elétrons retroespalhados (QSBD), para avaliação da heterogeneidade composicionais e de espectrometria de energia dispersiva (EED), para inferir a composição química qualitativa ou semiquantitativa dos materiais estudados.

No caso das seções delgadas, confeccionadas com impregnação prévia por resina epoxy, uma amostra desta resina foi estudada para conhecer sua composição química e estabelecer um parâmetro composicional de referência. De acordo com esta análise, a composição da resina inclui os seguintes elementos: $\mathrm{C}, \mathrm{Ca}, \mathrm{K}, \mathrm{Cl}, \mathrm{Na}$ e $\mathrm{O}$. 
CAPÍTULO V: APRESENTAÇÃO E DISCUSSÃO DOS RESULTADOS 


\section{1. - Classificação de arqueofácies}

A descrição macroscópica das seções verticais das trincheiras 10 e 11 permitiu identificar um total de cinco tipos de arqueofácies e quatro subfácies em função da composição (incluindo cor, textura e mineralogia), geometria externa, estruturas internas, conteúdo orgânico e componentes antrópicos das diferentes unidades observadas. Três das arqueofácies identificadas aparecem em ambos os perfis, assim como uma das subfácies; isso estaria indicando certa correspondência no processo responsável pela formação dessas unidades dentro do lócus 3, área onde se concentra este estudo. Na tabela 3, agrupam-se esquematicamente as informações detalhadas sobre as arqueofácies identificadas. material lítico. Castanho ou cinza escuro. Continua. Muito compactada.

2

Carvão e ossos queimados. Preta.

IA, III, V II, IV, VIA, VIC Contínua. Friável.

2.1

Cinzas junto com carvão e ossos queimados. Cor cinza. Contínua. Friável.

VII, IX, XI

3

Restos arqueo faunísticos (5-20\%) muito

II, IV

III fragmentados e alterados, conchas (às vezes concrecionadas). Castanho. Friável.

3.1 Restos arqueofaunísticos (30-50\%), carvão, cinzas e lentes de areia.

Castanho claro acinzentado. Friável.

3.2 Areia quartzosa, restos arqueofaunísticos isolados. Amarelo claro. Solta

3.3 Restos arqueofaunísticos (20\%). Castanho escuro. Muito friável.

4

Carvão e ossos carbonizados. Preta.

XIII Lenticular. Matriz rígida.

5

Cinzas, conchas concrecionadas, carvão

XIV e ossos carbonizados e queimados. Castanho escuro acinzentado. Rígida.

Tab. 3. - Arqueofácies e subfácies identificadas na T10 e T11. Caracterísiticas gerais (composição, cor e consistência ) e unidades arqueossedimentares onde foram identificadas. 
Jabuticabeira II

Lócus 3-Trincheira 11

Parede Sul
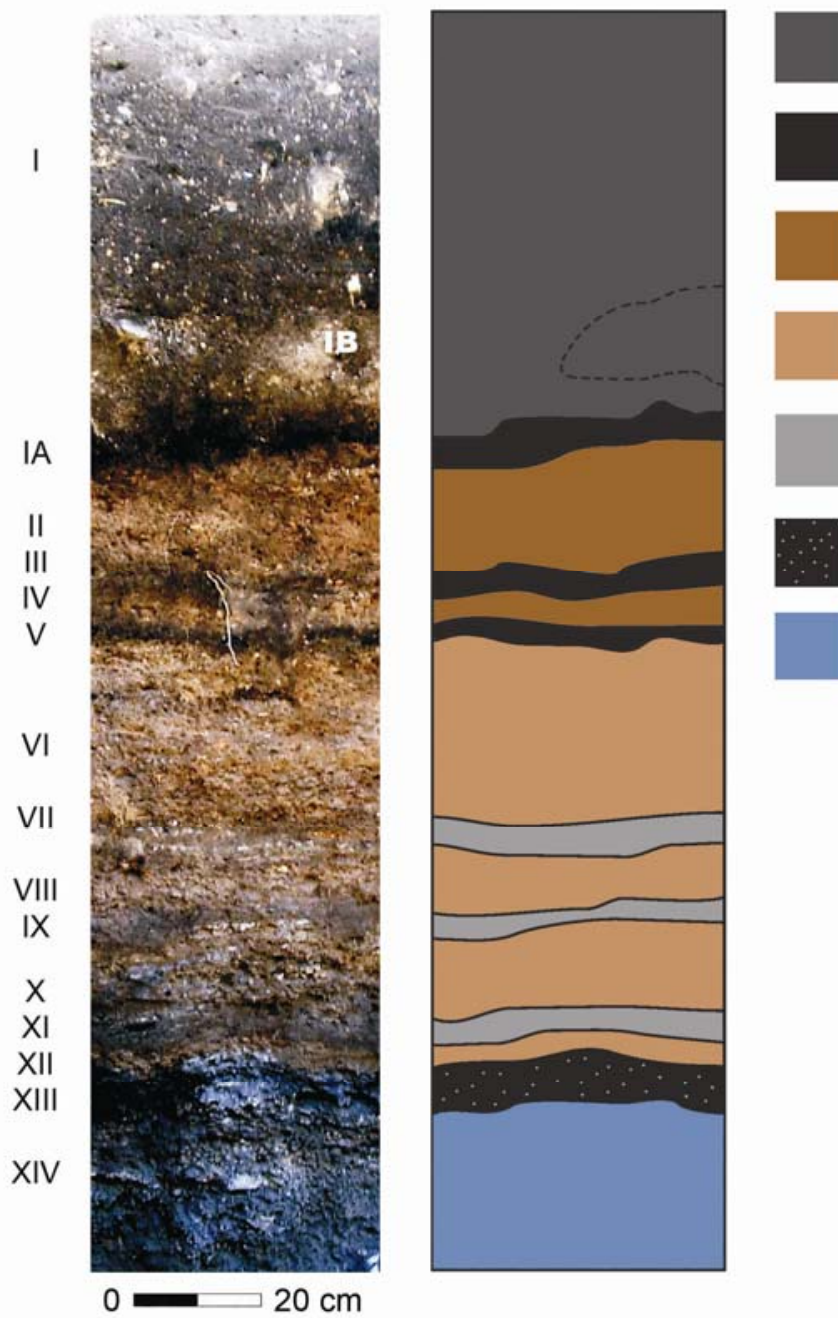

Arqueofácies 1

Arqueofácies 2

Arqueofácies 3

Subfácies 3.1

Subfácies 2.1

Arqueofácies 4

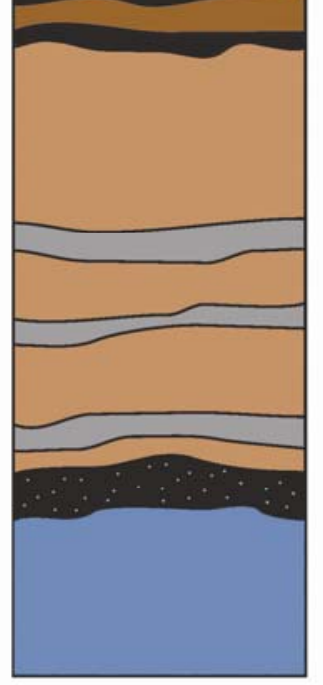

Arqueofácies 5

Fig. 11. - Seção da T11 com arqueofácies e subfácies identificadas a partir da descrição macroscópica feita em campo. 


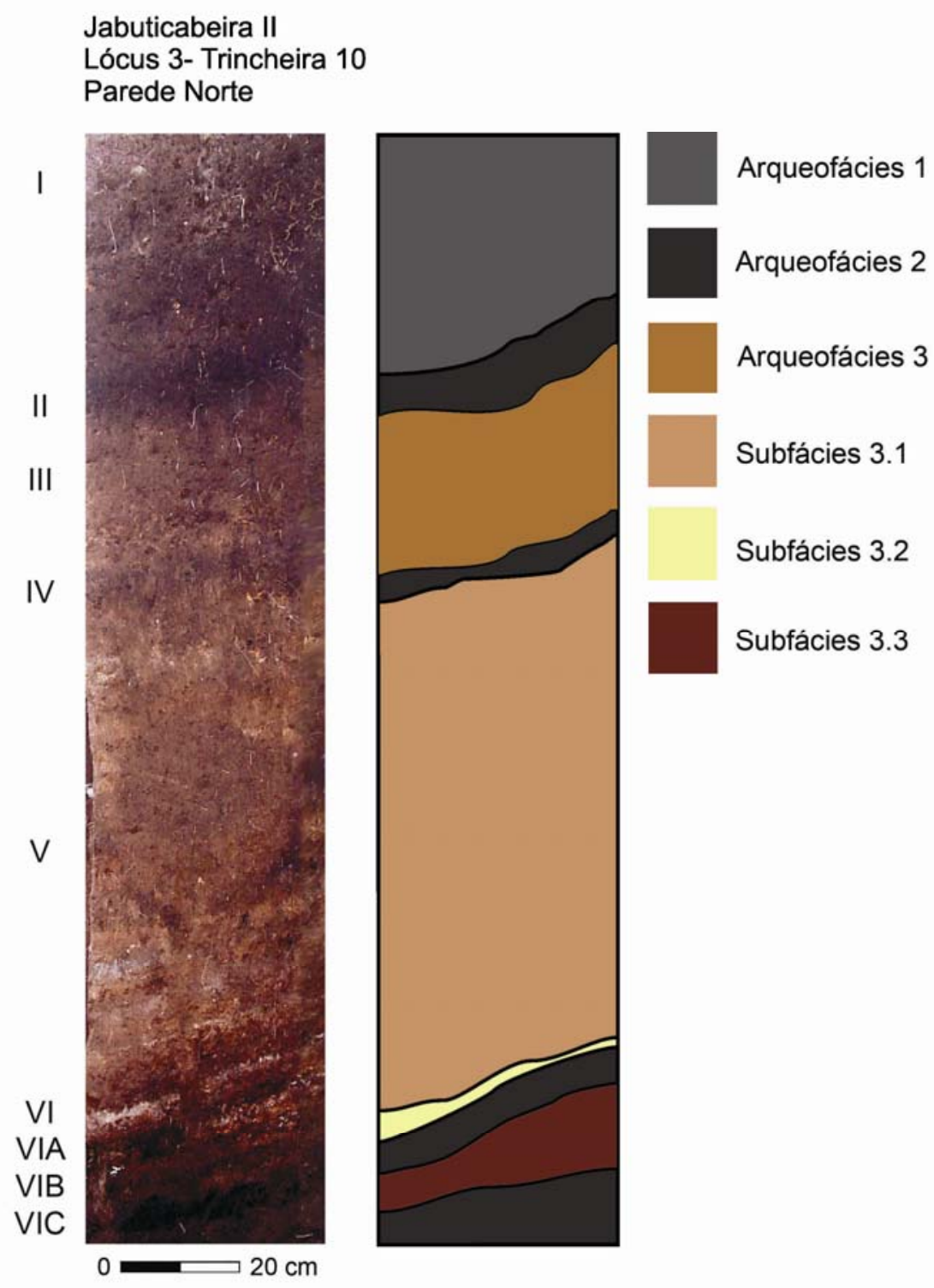

Fig. 12. - Seção da T10 com arqueofácies e subfácies identificadas a partir da descrição macroscópica feita em campo. 


\section{2. - Granulometria}

A análise granulométrica dos sedimentos tanto do sítio, como das sondagens no seu entorno, foi realizada com três objetivos pontuais: 1) caracterização física dos sedimentos da área de controle; 2) caracterização física das arqueofácies identificadas; 3) separar o componente natural dos sedimentos arqueológicos e utilizar sua distribuição granulométrica como parâmetro de comparação com os sedimentos naturais das proximidades do sítio.

\subsection{1. - Caracterização física dos sedimentos da área de controle}

As figuras 13 a 19 apresentam a localização dos sete pontos de amostragem na área de controle, junto com uma fotografia das seções amostradas, os histogramas de distribuição de freqüências granulométricas e as porcentagens de $\mathrm{MO}$ e $\mathrm{CaCO}_{3}$ para cada fácies sedimentar identificada em campo. Na maioria dos pontos amostrados, identificaram-se duas fácies com base em critérios de cor e proporção de materiais pelíticos: uma fácies lamosa superficial, preta e rica em $\mathrm{MO}$; e uma fácies arenosa amarela, situada na base dos perfis (ver figs. 13 a 18). Esta distinção, que pode ser de origem tanto sindeposicional como pós-deposicional (pedogênica), foi utilizada em campo para diferenciar as fácies sedimentares e para orientar a amostragem nas sondagens externas ao sítio.

Os mapas geológicos da região de localização do sambaqui Jabuticabeira II mostram dois sistemas deposicionais nas imediações ao sítio: eólico e paleolagunar (Giannini 1993; Giannini \& Santos 1994). Como nenhuma das fácies identificadas apresenta estruturas internas que possam ser atribuidas à deposição pelo vento, principalmente a fácies arenosa, e devido ao fato do limite entre as fácies ser abrupto e não gradual, como seria mais esperado no caso da diferenciação ser produzida por processos pedogênicos, interpreta-se que as fácies presentes nas sete sondagens da área externa ao sítio representam depósitos paleolagunares. Os depósitos amostrados apresentam distribuições granulométricas amplas para a fração terrígena, que vão da areia grossa até argila, com predomínio da fração areia fina nas amostras provenientes da planície nordeste e noroeste, e predomínio da fração areia média nas amostas da planície ao sul do sítio. 
A fácies superficial destes depósitos tem sido afetada por processos pedogênicos de sedimentação recente dando lugar à formação de solos incipientes $(\mathrm{A} / \mathrm{C})$ de tipo mineral. Nos pontos 1 a 6 teriam se desenvolvido neossolos quartzarênicos (textura arenosa, ausência de estrutura, horizonte $\mathrm{C}$ profundo), de tipo distrófico típico no ponto 1 (horizonte A fraco castanho claro, aproximadamente 1\% de MO e boa drenagem), e hidromórfico nos pontos 2 a 6 (horizonte A castanho escuro, maior teor de MO e má drenagem) (Embrapa Solos 1999).

A sondagem do ponto 7 (ver figura 19) apresenta a sobreposição de fácies turfosa preta e fácies cinza azulado saturada em água. A fácies cinza azulada foi interpretada como horizonte glei. Este depósito poderia corresponder a um depósito de turfa com dessenvolvimento de gleissolo de textura argilosa (mais de $60 \%$ de argila), seqüência incompleta A/C e altos teores de MO (superiores a $10 \%$ ) (Embrapa Solos 1999).

Portanto, com relação ao primeiro objetivo de sua aplicação, as análises granulométricas permitem chegar à seguinte conclusão:

O sítio Jabuticabeira II encontra-se localizado numa área de depósitos paleolagunares sobre os quais se acham em desenvolvimento solos minerais incipientes. que diferem principalmente no conteúdo de $\mathrm{MO}$ 

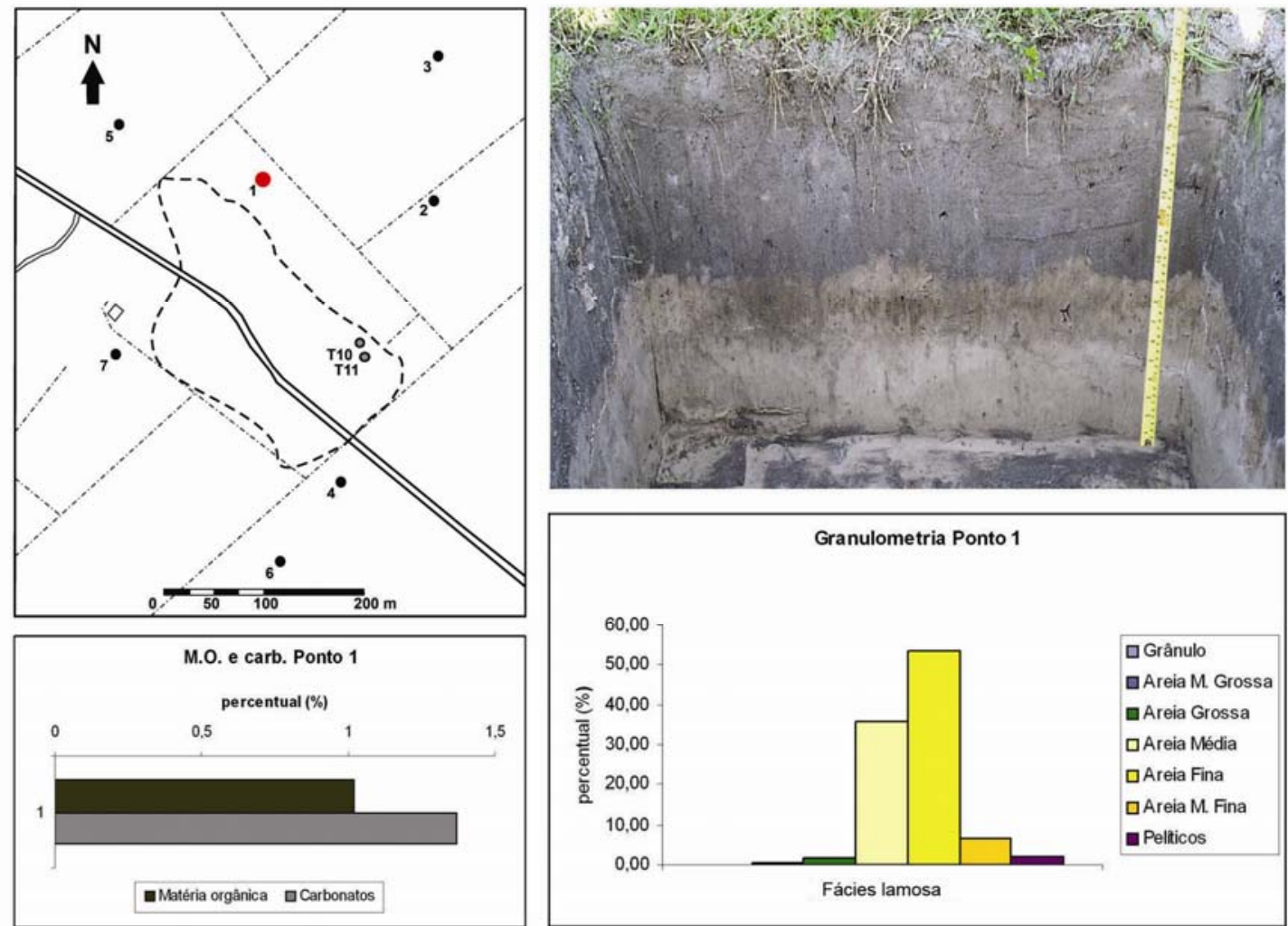

Fig. 13. - Localização do ponto de amostragem 1 (superior esquerda), foto do perfil amostrado (superior direita), histograma da distribuição granulométrica para a fácies lamosa (inferior direita) e porcentagens de $\mathrm{MO}$ e $\mathrm{CaCO}_{3}$ (inferior esquerda).
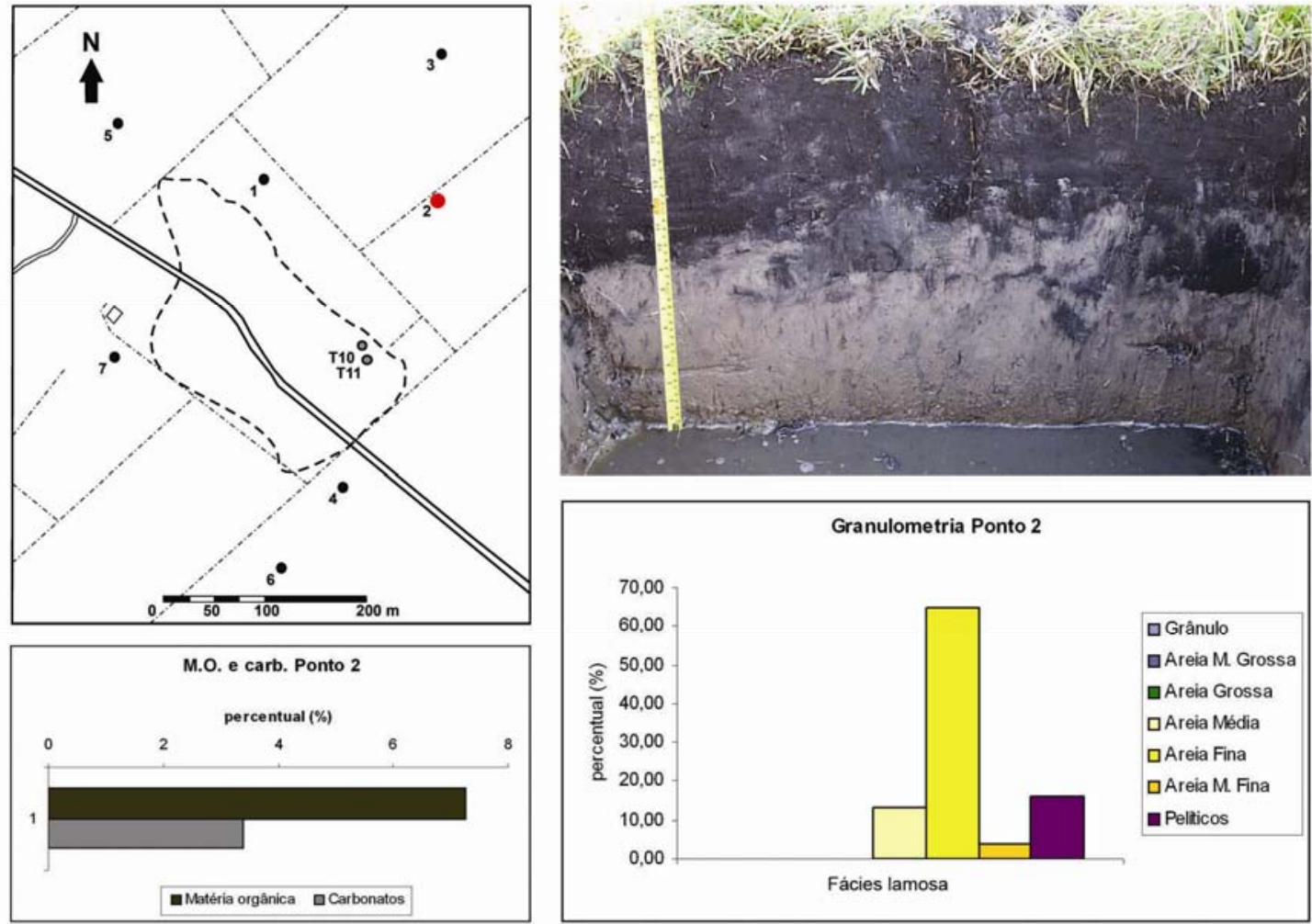

Fig. 14. - Localização do ponto de amostragem 2 (superior esquerda), foto do perfil amostrado (superior direita), histograma da distribuição granulométrica para a fácies lamosa (inferior direita) e porcentagens de $\mathrm{MO}$ e $\mathrm{CaCO}_{3}$ (inferior esquerda). Note-se o aumento no teor de $\mathrm{MO}$ em relação ao ponto 1. 

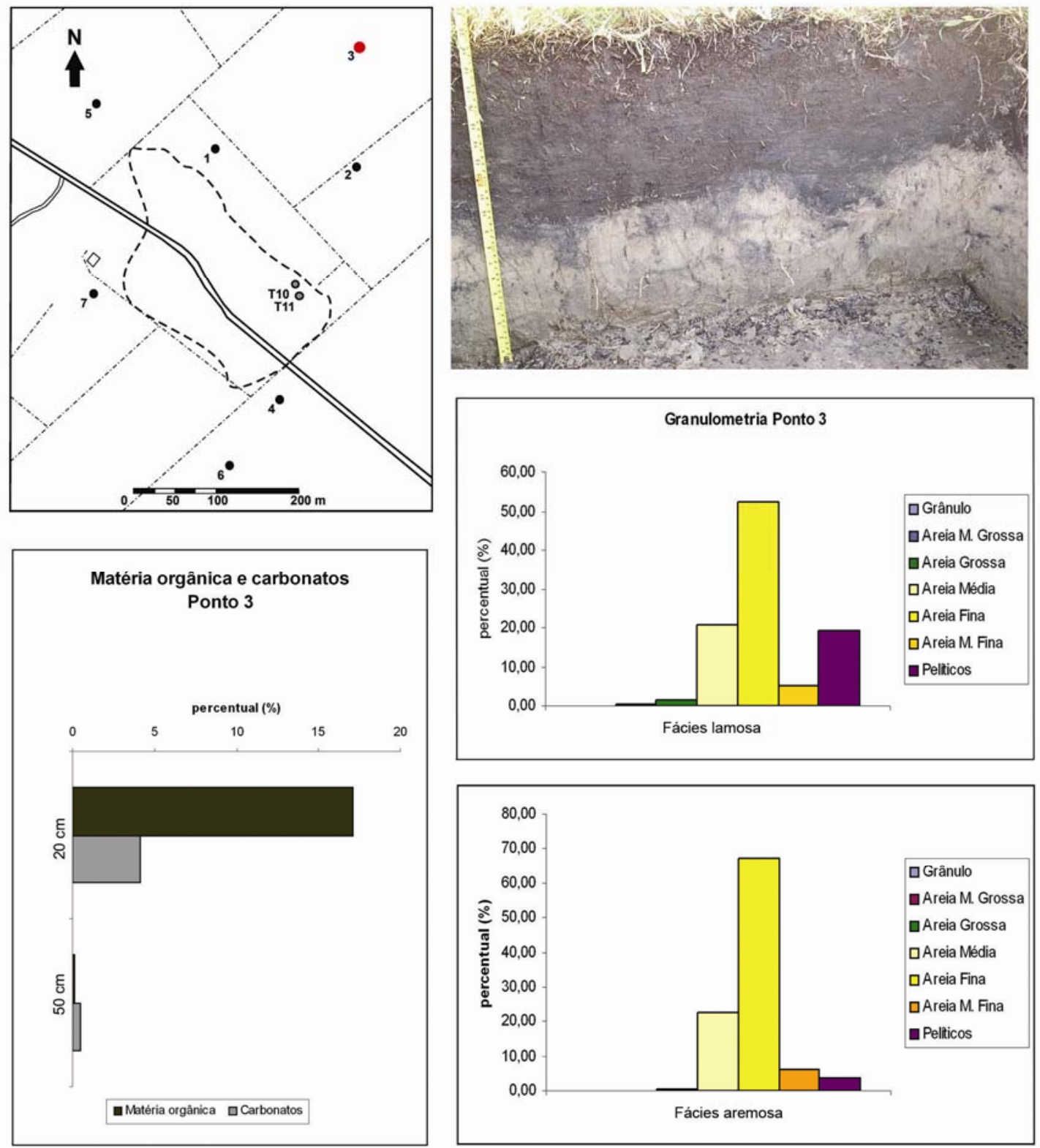

Fig. 15. - Localização do ponto de amostragem 3 (superior esquerda), foto do perfil amostrado (superior direita), histograma da distribuição granulométrica para a fácies lamosa e arenosa (inferior direita) e porcentagens de $\mathrm{MO}$ e $\mathrm{CaCO}_{3}$ (inferior esquerda). Note-se o aumento considerável do teor de $\mathrm{MO}$ em relação aos pontos anteriores. 

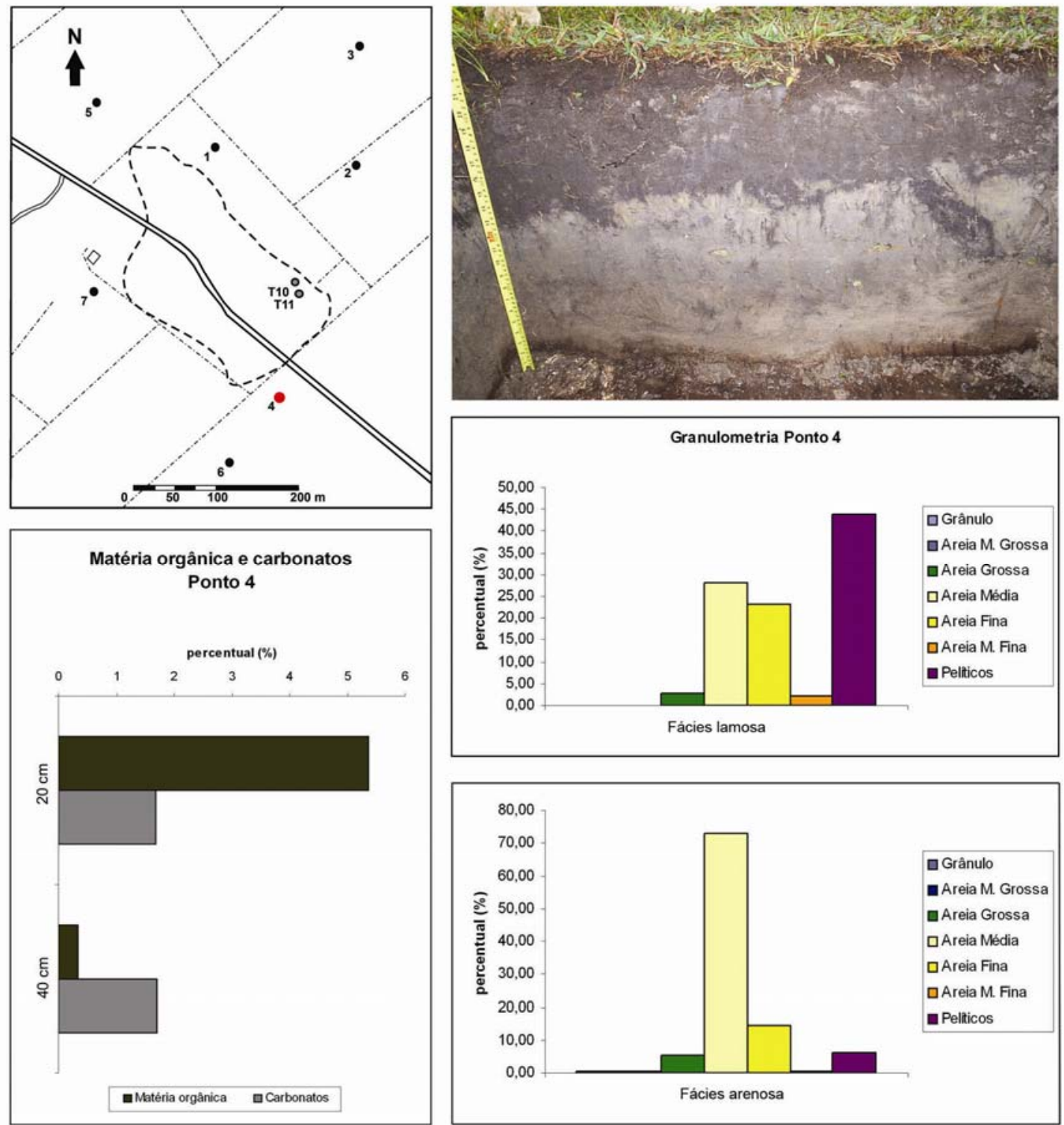

Fig. 16. - Localização do ponto de amostragem 4 (superior esquerda), foto do perfil amostrado (superior direita), histograma da distribuição granulométrica para as fácies lamosa e arenosa (inferior direita), e porcentagens de $\mathrm{MO}$ e $\mathrm{CaCO}_{3}$ (inferior esquerda). Note-se o depósito de conchas natural na base do perfil e o aumento na proporção de pelíticos na fácies lamosa. 


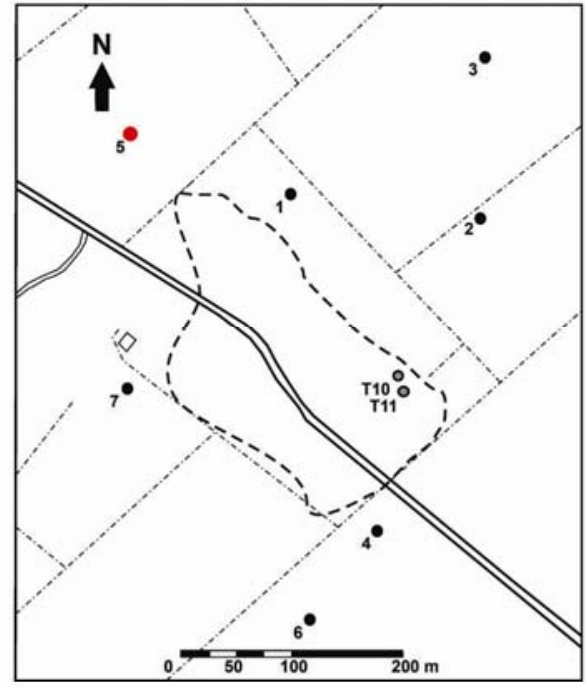

M.O. e carb. Ponto 5
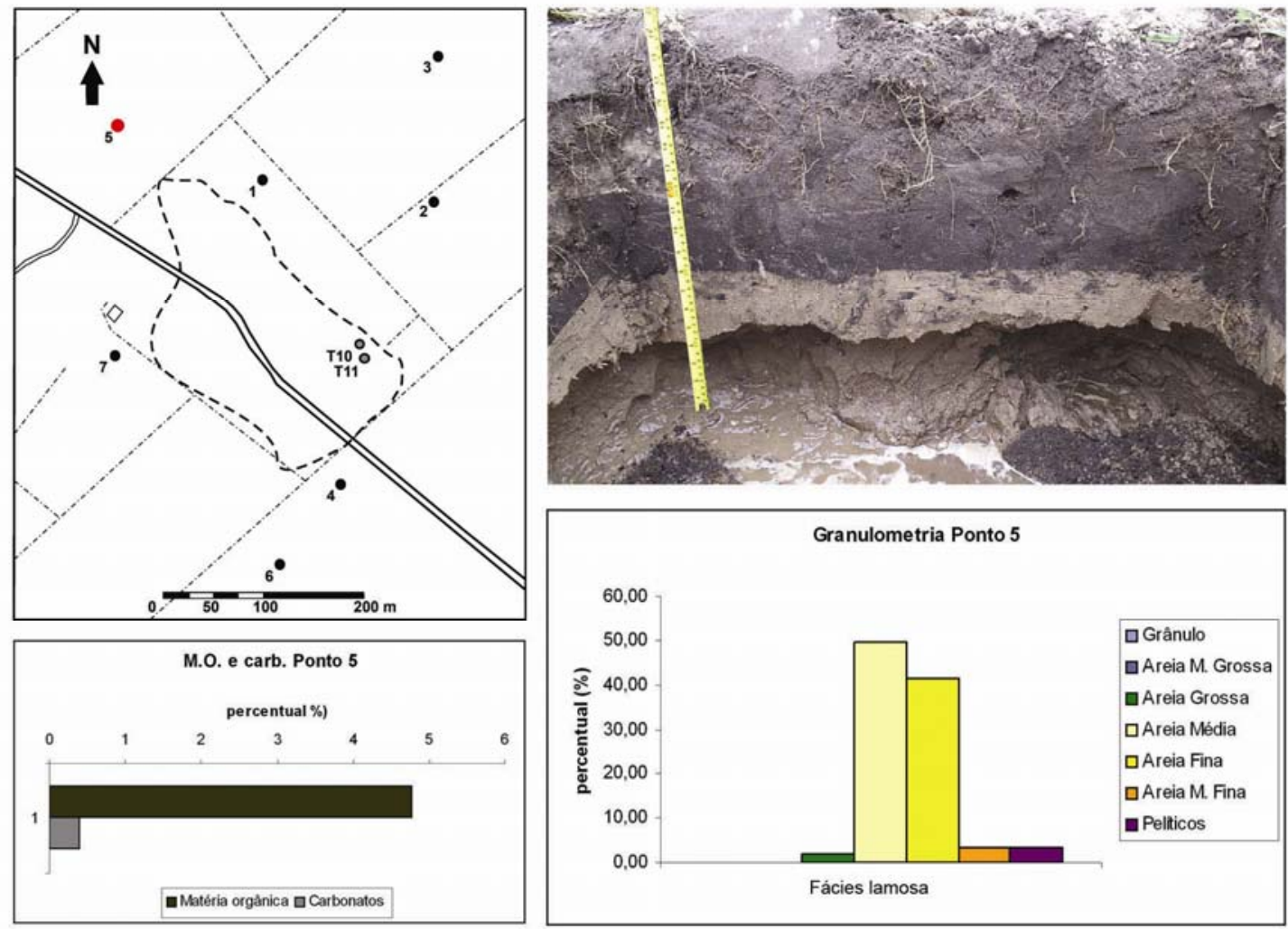

Fig. 17. - Localização do ponto de amostragem 5 (superior esquerda), foto do perfil amostrado (superior direita), histograma da distribuição granulométrica para a fácies lamosa (inferior direita) e porcentagens de $\mathrm{MO}$ e $\mathrm{CaCO}_{3}$ (inferior esquerda). Note-se o aumento na proporção de areia média em relação aos pontos $2 \mathrm{e} 1$. 

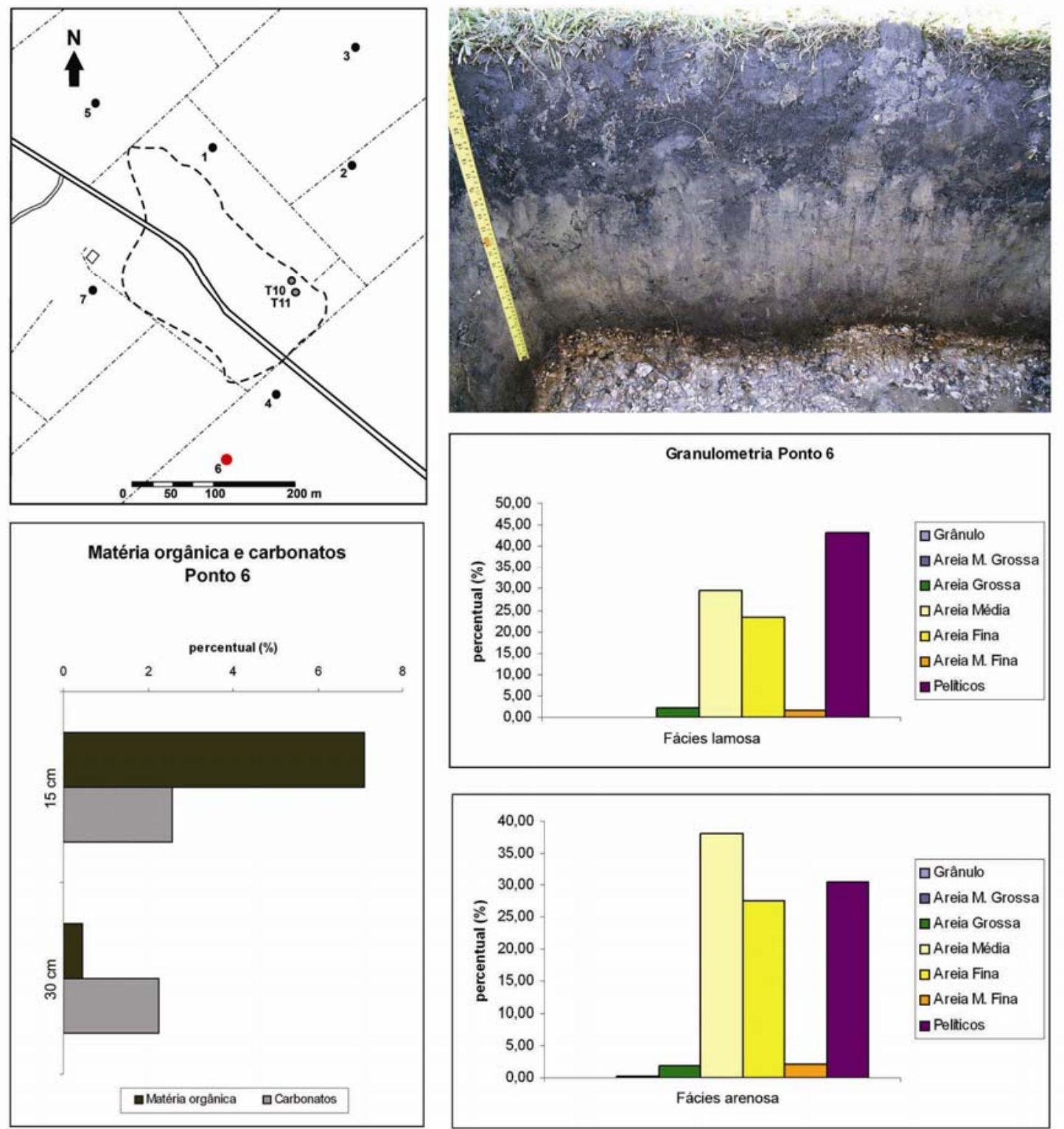

Fig. 18. - Localização do ponto de amostragem 6 (superior esquerda), foto do perfil amostrado (superior direita), histograma da distribuição granulométrica para as fácies lamosa e arenosa (inferior direita) e porcentagens de $\mathrm{MO}$ e $\mathrm{CaCO}_{3}$ (inferior esquerda). Note-se o depósito de conchas natural na base do perfil e a alta proporção de sedimentos pelíticos em ambas as fácies amostradas. 


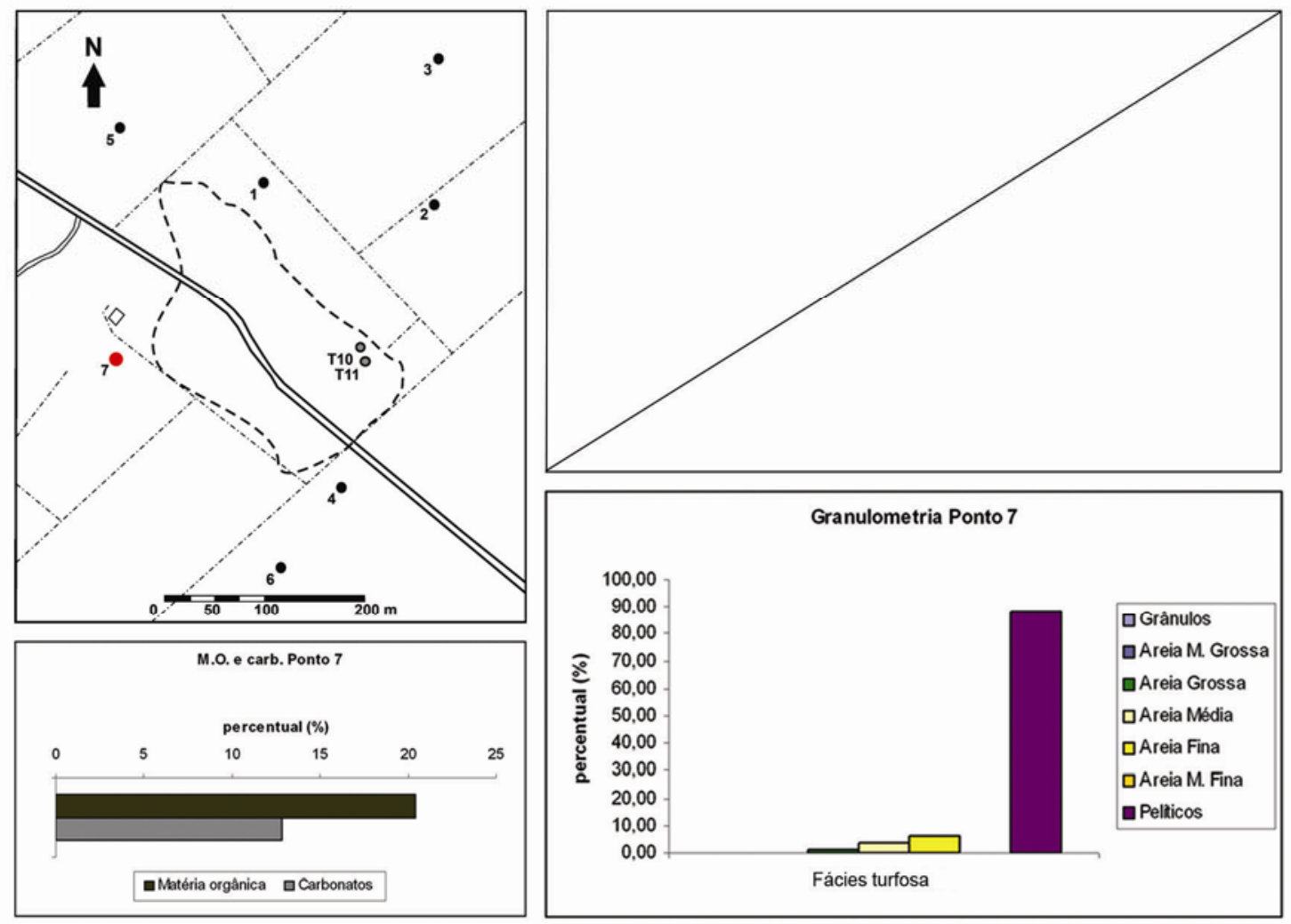

Fig. 19. - Localização do ponto de amostragem 7 (superior esquerda) sem foto do perfil amostrado, histograma da distribuição granulométrica para a fácies turfosa identificada (inferior direita) e porcentagens de $\mathrm{MO}$ e $\mathrm{CaCO}_{3}$ (inferior esquerda). Apresenta o maior teor de $\mathrm{MO}$, a maior concentração de pelíticos e a menor proporção de areias de todos os pontos amostrados; não apresenta a fácies arenosa que se observa nas demais sondagens.

\subsection{2. - Caracterização física de arqueofácies}

Para alcançar o segundo objetivo das análises granulométricas, adotou-se um procedimento que tentou preservar os componentes dos sedimentos arqueológicos na maior completitude possível (ver tópico 4.3.3). Este procedimento de análise granulométrica, aplicado às amostras da T11, permitiu apreciar como o conteúdo antrópico dos sedimentos arqueológicos (principalmente ossos e carvão) é apreciável em todas as frações granulométricas, desde a fração cascalho até silte (e provavelmente argila). Da mesma maneira, permitiu observar que as areias terrígenas quartzosas são o componente natural predominante nos sedimentos arqueológicos. 
Portanto:

A camada preta apresenta macroscopicamente uma combinação de elementos de caráter natural, representado pelas areias quartzosas, e antrópico, representado pelos restos arqueofaunísticos e os carvões que se encontram em todas as arqueofácies identificadas e em quase a totalidade das frações granulométricas.

Os restos arqueofaunísticos da camada preta apresentam claras evidências de queima, dadas pela coloração diferencial dos ossos, que vai do amarelo, marrom avermelhado até o preto, indicando diferentes graus de queima.

De acordo com McCutcheon (1992), ossos aquecidos a temperaturas que vão dos 20 aos $600^{\circ} \mathrm{C}$ apresentam efetivamente variação de coloração ao olho nu conforme o incremento de temperatura. Segundo o autor, ossos sem aquecimento possuem cor amarelo pálido a branco, passando a marrom pálido a amarelo avermelhado somente quando aquecidos a temperaturas entre 130 e $240^{\circ} \mathrm{C}$. Acima de $240^{\circ} \mathrm{C}$ as colorações variam entre marrom escuro avermelhado, preto e marrom muito pálido e, a $500^{\circ} \mathrm{C}$, tende a cinzenta e amarronzada. Quando os ossos alcançam temperaturas maiores que a temperatura de destruição da matéria orgânica, acima dos $500^{\circ} \mathrm{C}$ e até $950^{\circ} \mathrm{C}$, a cor branca, característica da calcinação, sempre aparece.

Porém, as mudanças na coloração dos ossos como resultado da queima, enquanto mostram uma progressão gradual desde marrom, preto, cinza a branco, variam consideravelmente entre diferentes tipos de ossos sujeitos à mesma temperatura e pelo mesmo período de tempo. Os ossos de peixe, por exemplo, têm comportamento diferente, no aquecimento, em relação a ossos de ave ou mamífero. Todos são calcinados a partir dos $600-700^{\circ} \mathrm{C}$, porém, os ossos de peixe começam a exibir cores pretas relacionadas à carbonização a temperaturas menores, isto é, a partir dos $300^{\circ} \mathrm{C}$ (Nicholson 1998: 415).

As mudanças na coloração dos ossos não estão unicamente vinculadas à temperatura de aquecimento, mas também ao tipo de osso, à posição dentro da fogueira e ao tempo de exposição à queima. Esta situação é agravada pelas alterações que os ossos sofrem como resultado dos processos de intemperismo, que provocam alterações semelhantes àquelas ocasionadas pela queima (ver tópico 5.2.3) (Shipman et al. 1984; McCutcheon 1992; Nicholson 1998; Trueman et al. 2004). As mudanças de coloração que os ossos frescos sofrem pelo intemperismo durante milhares de anos são 
equivalentes àquelas sofridas instantaneamente durante a queima, até o nível de carbonização (Steiner et al. 1995). Igualmente, os ossos enterrados num depósito sofrem o tingimento da sua superfície pelos materiais que percolam o sedimento, podendo chegar a conferir a um osso fresco a coloração de um osso queimado ou até carbonizado.

Considerando que a coloração dos ossos não é por si mesma um elemento suficiente para identificar diferentes temperaturas de aquecimento, principalmente porque a coloração também muda consideravelmente na diagênese de ossos que têm sido enterrados em depósitos sedimentares ou arqueossedimentares, neste trabalho não se realizaram quantificações de restos arqueofaunísticos quanto a queima do material.

Estudos mais sistemáticos focados nas alterações térmicas e diagenéticas sofridas pelos restos arqueofaunísticos da camada preta, com aplicação de microscopia eletrônica de varredura, espectroscopia de transformação infravermelha de Fourier, análises termogravimétricos, entre outros, poderão responder com maior segurança a este tipo de questão.

Geralmente, a queima dos ossos é tomada como evidência do cozimento dos alimentos para consumo. Porém a queima dos ossos reflete seu grau de aquecimento e só pode ser atingida mediante a exposição direta do material ao fogo, já que o recobrimento pela carne impede que os ossos alcançem as altas temperaturas necessárias para produzi-las (Shipman et al. 1984: 323).

Portanto, poder-se-ia interpretar que:

Os restos arqueofaunísticos que compõem a camada escura foram expostos à ação direta do fogo uma vez consumida sua carne. Isto provocou a intensa queima que vários deles sofreram, e que só pode ser atingida mediante o contato direto do osso com a fonte de calor e não como resultado do cozimento per se.

Somente aqueles ossos em contato direto com o fogo são totalmente calcinados, enquanto ossos mais afastados verticalmente ou horizontalmente da ação das chamas sofrem com menor intensidade os efeitos das altas temperaturas. Ossos enterrados embaixo de fogueiras, por exemplo, sofrem a ação do aquecimento produzido na superfície até $5 \mathrm{~cm}$ de profundidade, chegando no máximo até o nível de carbonização, mas não chegam a ser calcinados nem a temperaturas superficiais maiores que $900^{\circ} \mathrm{C}$. Aqueles ossos localizados a maiores profundidades que $5 \mathrm{~cm}$ ficam totalmente 
inalterados (Steiner et al. 1995). Isto está relacionado com as temperaturas que os solos ou sedimentos alcançam sob as fogueiras. Com uma fogueira de até $900^{\circ} \mathrm{C}$ de temperatura, o máximo de calor atingido a $1 \mathrm{~cm}$ de profundidade é de $500^{\circ} \mathrm{C}$. Já a profundidades maiores que $5 \mathrm{~cm}$ as temperaturas decrescem exponencialmente do valor máximo de $200^{\circ} \mathrm{C}$ (Canti \& Linford 2000).

A partir da observação dos resultados expressos na figura 20, pode-se apreciar a polimodalidade e a assimetria como características comuns às distribuições granulométricas de todas as arqueofácies. Os histogramas dessa figura permitem observar a marcada assimetria da distribuição, com prolongamento da cauda nas frações pelíticas, entre as quais predominam silte grosso e argila, e moda principal nas frações arenosas, onde predominam as classes areia grossa e areia média. Da mesma maneira, em todas as amostras (menos a unidade XII), a fração areia muito grossa é geralmente pouco representada, assim como a fração areia muito fina, o que se expressa na compartimentação da distribuição segundo três frações: pelítica, numa cauda; areia fina, média e grossa, na parte central; areia muito grossa e cascalho, na cauda oposta. Cabe destacar também a baixa proporção de pelíticos que caracteriza a subfácies 2.1 .

Em termos gerais, distribuições polimodais assimétricas atribuem-se a mistura várias populações de sedimentos de distribuição granulométrica unimodal (gaussiana ou normal) (Spencer 1963; Visher 1969). Este seria o caso dos sedimentos arqueológicos da T11, cujos histogramas estariam indicando então a presença conjunta de várias populações de sedimentos, em cada arqueofácies. Este padrão estaria ligado ao aporte antrópico, neste caso caracterizado pela adição de fragmentos de osso e carvões, entre outros, em quase todas as frações granulométricas.

Os conglomerados de fluxos de massa e aqueles materiais que não sofreram transporte ou que foram pouco transportados, tendem a não se ajustar à distribuição simétrica de Gauss (lognormal) e sim à distribuição assimétrica de Rosin (Kittleman 1964). Este fato tem sido associado ao grau de transporte sofrido pelas partículas sedimentares. Sedimentos imaturos tendem a apresentar distribuições próximas à de Rosin, mas na medida em que aumenta o seu transporte o ajuste à distribuição de Rosin tende a diminuir e o ajuste à distribuição de Gauss tende a aumentar (Schleyer 1987). 

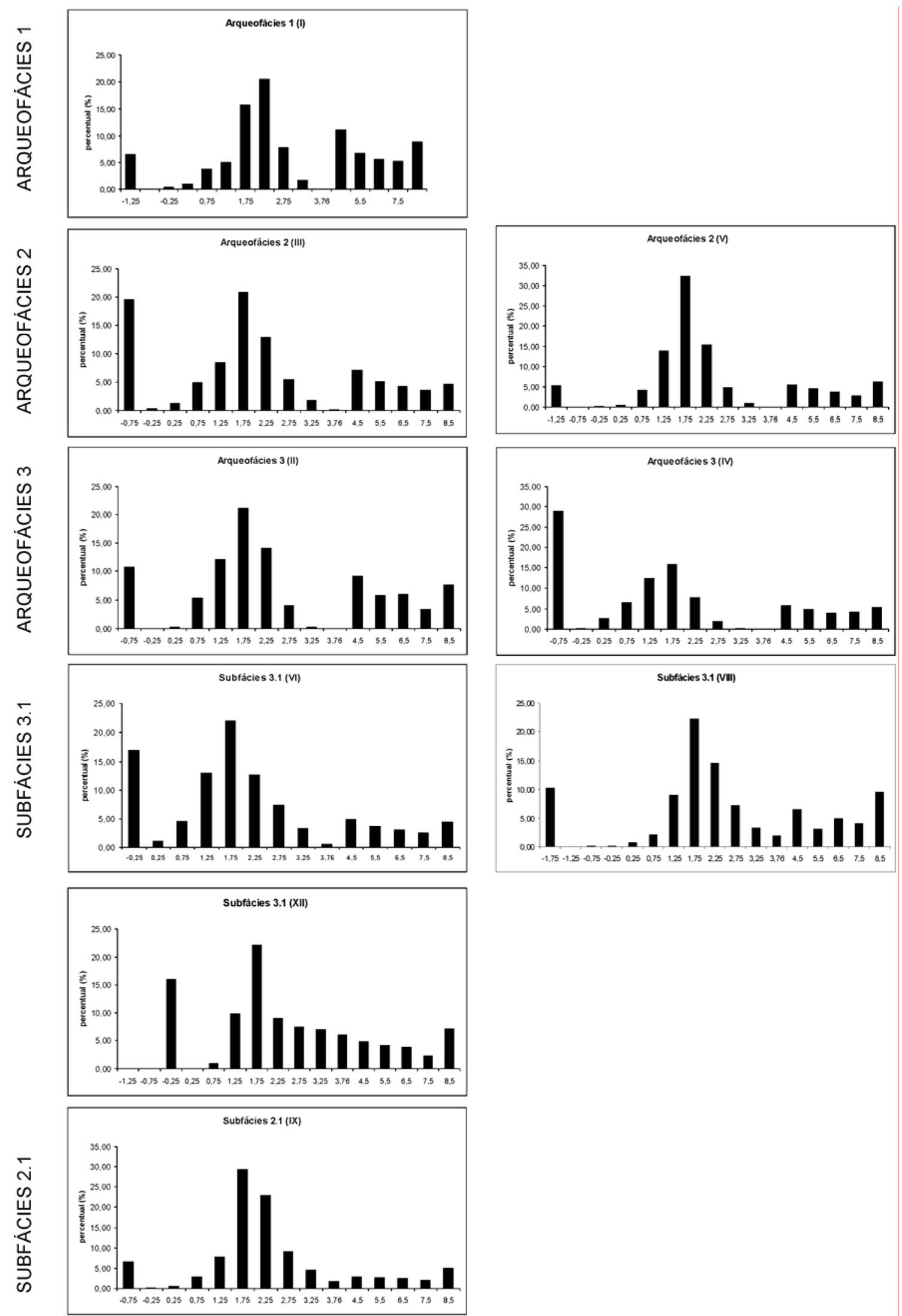

Fig. 20. - Histogramas da distribuição granulométrica para as arqueofácies da T11. Classes granulométricas expressadas em phi (grânulo: -2; areia mto. grossa: -1; areia grossa: 0; areia média: 1; areia fina: 2; areia mto. fina: 3; silte grosso: 4; silte médio: 5; silte fino: 6; silte mto. fino: 7; argila: 8). Valor indicado nas abscissas corresponde ao ponto médio do intervalo granulométrico. 
Nos sedimentos arqueológicos, as adições antrópicas representam uma população sedimentar de transporte nulo que é incorporada aos materiais naturalmente depositados, ou como acontece no caso da camada preta, que é misturada com materiais de origem natural. O intemperismo sofrido por estes elementos orgânicos e minerais de origem orgânica, assim como sua alta fragilidade, pode também ter interferido por sua maior concentração em algumas frações, especialmente areia grossa e pelíticos.

O caráter polimodal assimétrico dos sedimentos arqueológicos da T11 indica sua compatibilidade com o padrão considerado típico por Brochier (2002).

\subsection{3. - Comparação entre sedimentos naturais e arqueológicos}

Para alcançar o terceiro objetivo se utilizou unicamente a granulometria da fração de origem terrígena. Buscou-se um método que permitisse descartar o componente orgânico e inorgânico bioclástico dos sedimentos arqueológicos e naturais para assim poder relacionar ambos os grupos de amostras.

Pelo método de perda de massa ao ataque químico, foram estimadas as concentrações de ossos e $\mathrm{CaCO}_{3}$ nos sedimentos da $\mathrm{T} 10$ e T11. Na T10, a porcentagem destes materiais manteve-se aproximadamente constante ao longo das arqueofácies 1, 2, 3 e na subfácies 3.1. (entre 45-60\%), mas apresentou marcada diminuição na arqueofácies $3.3(18 \%)$, na base do perfil. Na T11, os maiores teores foram identificados nas arqueofácies 1, 3 e na subfácies 3.1 (40-50\%), enquanto os menores valores foram registrados nas arqueofácies 2 e na subfácies 2.1 (18-25\%). Os teores aproximados de MO somente foram determinados nas amostras da T11 e expressam, em termos gerais, baixas porcentagens para a totalidade das arqueofácies e subfácies identificadas em comparação com os valores encontrados na área de controle. Porém, cabe destacar que os maiores teores foram os obtidos para a arqueofácies 1, provávelmente mais afetada por processos pedogênicos, e para a arqueofácies 3 e a subfácies 3.1; enquanto isso, os teores mais baixos foram registrados para a arqueofácies 2 e a subfácies 2.1, identificadas como compostas majoritariamente por materiais queimados.

Na fig. 21 apresentam-se os gráficos correspondentes às medias dos parâmetros estatísticos da distribuição granulométrica para os seis conjuntos de amostras sob comparação. É importante reiterar que esta comparação levou em consideração apenas a 
fração areia. Os dados correspondentes ao sítio Jabuticabeira II e à paleolaguna foram obtidos a partir da amostragem feita na $\mathrm{T} 11$ e nos sete pontos de sondagem nas proximidades do sítio, respectivamente. Os dados para as quatro gerações de dunas foram extraídos das teses de Giannini (1993) e das dissertações de Sawakuchi (2003) e Martinho (2004). Foram somente considerados aqueles provenientes de amostras da região que vai do Cabo de Santa Marta até a Praia Grande do Sul, portanto nos arredores mais imediatos do sambaqui Jabuticabeira II.

Estes gráficos permitem observar um fato de marcada importância na caracterização dos sedimentos arqueológicos que compõem a camada preta. Pela proximidade e muitas vezes superposição dos intervalos de confiança para as médias dos parâmetros analisados, pode-se inferir que as areias terrígenas que compõem os sedimentos da camada preta apresentam uma maior proximidade granulométrica com os sedimentos da paleolaguna que com os sedimentos das quatro gerações de dunas.
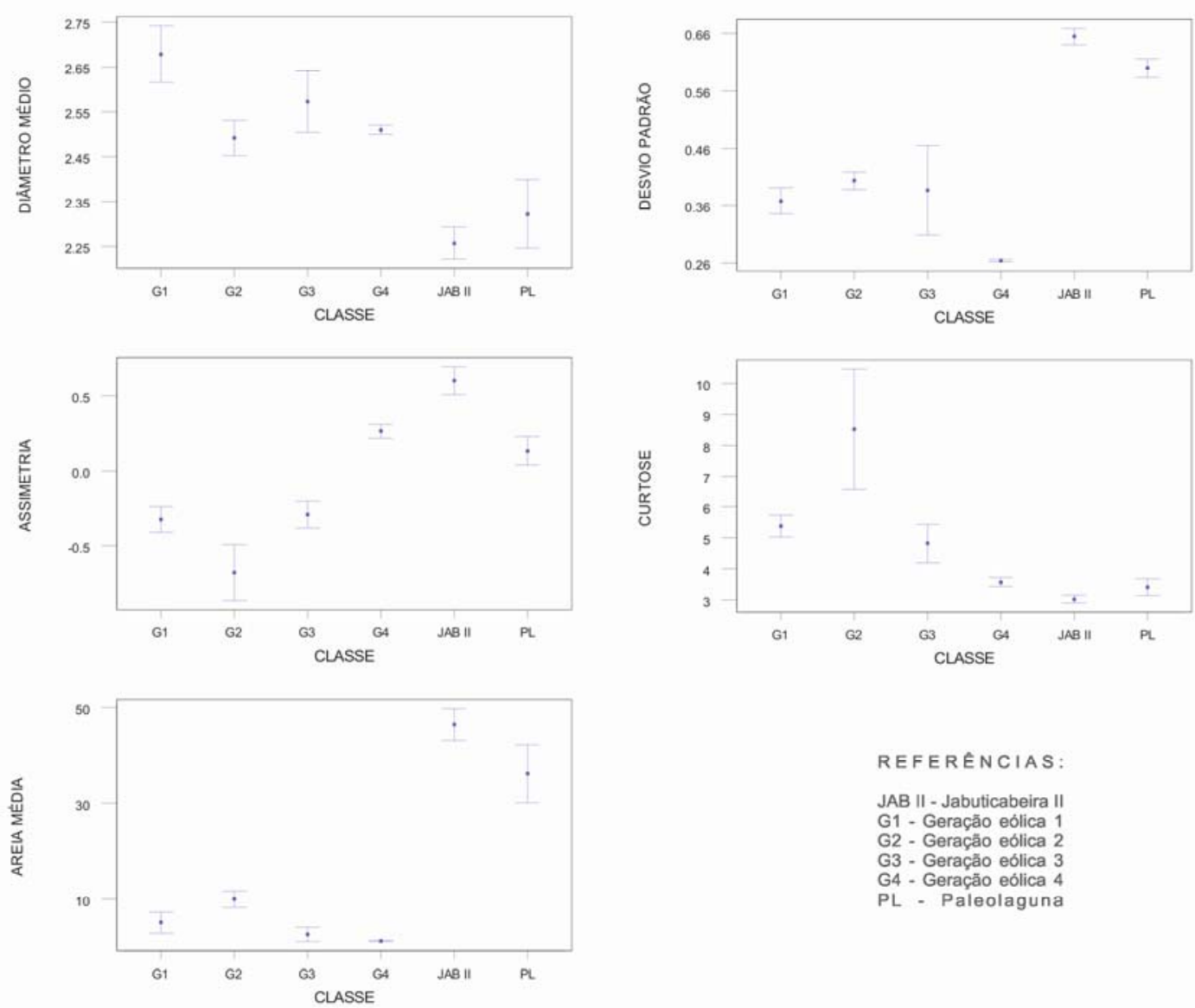

Fig. 21. - Comparação de parâmetros estatísticos da distribuição granulométrica e fração areia média. Amostras coletadas no sítio Jabuticabeira II, as quatro gerações eólicas e nos sedimentos paleolagunares das proximidades ao sítio. Valores médios com intervalo de confiança (expressados em phi). 
As areias dos sedimentos da camada preta apresentam maior proximidade com as areias dos sedimentos paleolagunares, principalmente na comparação das variáveis teor de areia média, diâmetro médio e desvio padrão. Esta similaridade pode traduzir possível vinculação genética, ou seja, que a presença destas areias paleolagunares no sítio se deva a processos antrópicos de coleta e transporte. No caso das variáveis assimetria e curtose, os sedimentos arqueológicos apresentam proximidade tanto com os sedimentos da paleolaguna como com os sedimentos eólicos da geração 4 (dunas ativas).

Para aprofundar a comparação entre os conjuntos de amostras, construíram-se diagramas de dispersão que combinam os parâmetros estatísticos das distribuições granulométricas para o total de amostras das dunas eólicas (abrangendo todas as gerações), da paleolaguna e do sítio arqueológico (fig. 22).

Os diagramas representados na figura 22 corroboram o vínculo existente entre as areias terrígenas do depósito arqueológico e as dos depósitos paleolagunares. Estes dois tipos de sedimentos formam nuvens de pontos bem delimitadas e com forte sobreposição entre si, em alguns casos, dentro do conjunto de valores referente aos sedimentos eólicos, e em outros, separados claramente do agrupamento desse conjunto (caso dos diagramas de diâmetro médio vs. desvio padrão, desvio padrão vs. assimetria e desvio padrão vs. curtose).

Assim, o terceiro objetivo proposto para as análises granulométricas permite chegar à seguinte conclusão:

As areias terrígenas que compõem as arqueofácies identificadas na T11 apresentam maior semelhança, em termos granulométricos, com os sedimentos paleolagunares que com os sedimentos eólicos que se encontram na região de localização do sítio. 

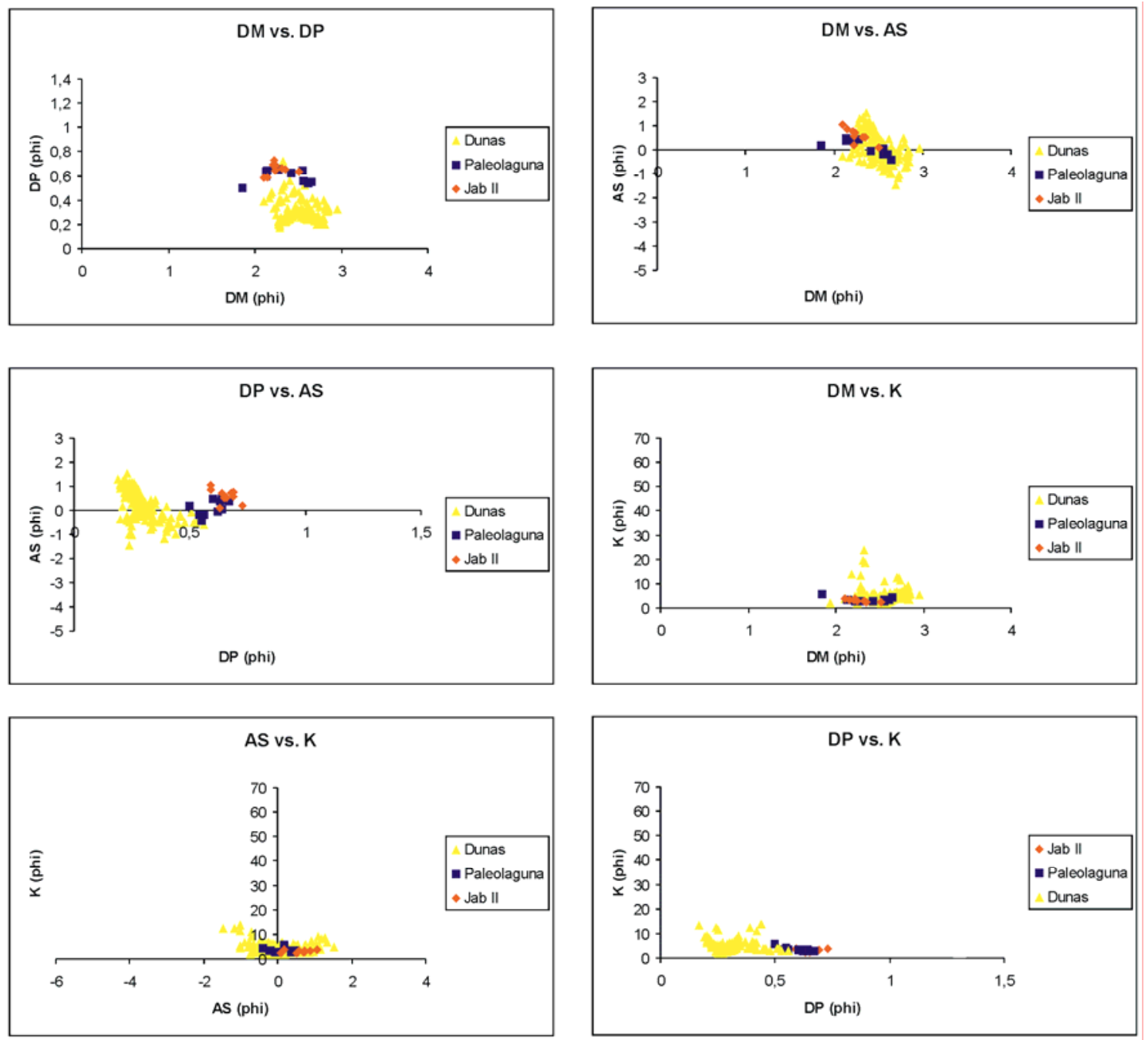

Fig. 22. - Diagramas de dispersão para os parâmetros estatísticos da fração areia nas amostras provenientes das gerações de dunas eólicas, paleolaguna e Jabuticabeira II. DM: diâmetro médio; DP: desvio padrão; AS: assimetria; K: curtose.

\section{3. - Análise química multi-elemental}

Em sedimentos arqueológicos ou antrossolos os elementos químicos considerados de maior significância para aproximar-se à história ocupacional de um sítio são: fósforo $(\mathrm{P})$, carbono $(\mathrm{C})$, nitrogênio $(\mathrm{N})$, cálcio $(\mathrm{Ca})$, magnésio $(\mathrm{Mg})$, sódio $(\mathrm{Na})$ e potássio $(\mathrm{K})$, flúor $(\mathrm{F})$, manganês $(\mathrm{Mn})$, ferro $(\mathrm{Fe})$, alumínio (Al), zinco $(\mathrm{Zn})$, titânio (Ti), cobalto (Co), estrôncio (Sr), entre outros (Cook \& Heizer 1965; Linderholm \& Lundberg 1994; Parnell et al. 2002; Middleton 2004). A concentração total na forma de óxido para todos 
estes elementos maiores e menores, foi analisada nas amostras da T11 e nos quatro pontos selecionados na área de controle.

O elemento de maior destaque na composição da fração sólida de ambos os grupos de amostras (T11 e área de controle) foi o silício $\left(\mathrm{SiO}_{2}\right)$. Este elemento constitui mais da metade da composição da camada preta e da fácies lamosa na área de controle (fig. 23). Isto já tinha sido constatado nas análises granulométricas onde se observou que as areias quartzosas representavam o componente principal dos sedimentos paleolagunares e o elemento natural de maior representatividade na camada preta. $O$ ponto 5 possui a maior percentagem de $\mathrm{SiO}_{2}$ na sua composição, seguido pelos pontos 3 e 6. Nestes pontos, a concentração de $\mathrm{SiO}_{2}$ pode ser tomada como reflexo da elevada porcentagem de areia na sua composição, valores também respaldados pelas análises granulométricas (figs. 15, 17 e 18). Não obstante, no ponto 7, que apresentou marcado predomínio de sedimentos pelíticos na granulometria (fig. 19), a concentração de $\mathrm{SiO}_{2}$ estaria relacionada majoritariamente à presença de quartzo na fração silte e de filossilicatos na fração argila.

A porcentagem de $\mathrm{SiO}_{2}$ na T11 é variável, mostrando os maiores valores na base do perfil. Porém, cabe ressaltar que a média da concentração de areias quartzosas na camada escura não chega a ultrapassar os valores registrados nos sedimentos paleolagunares. 

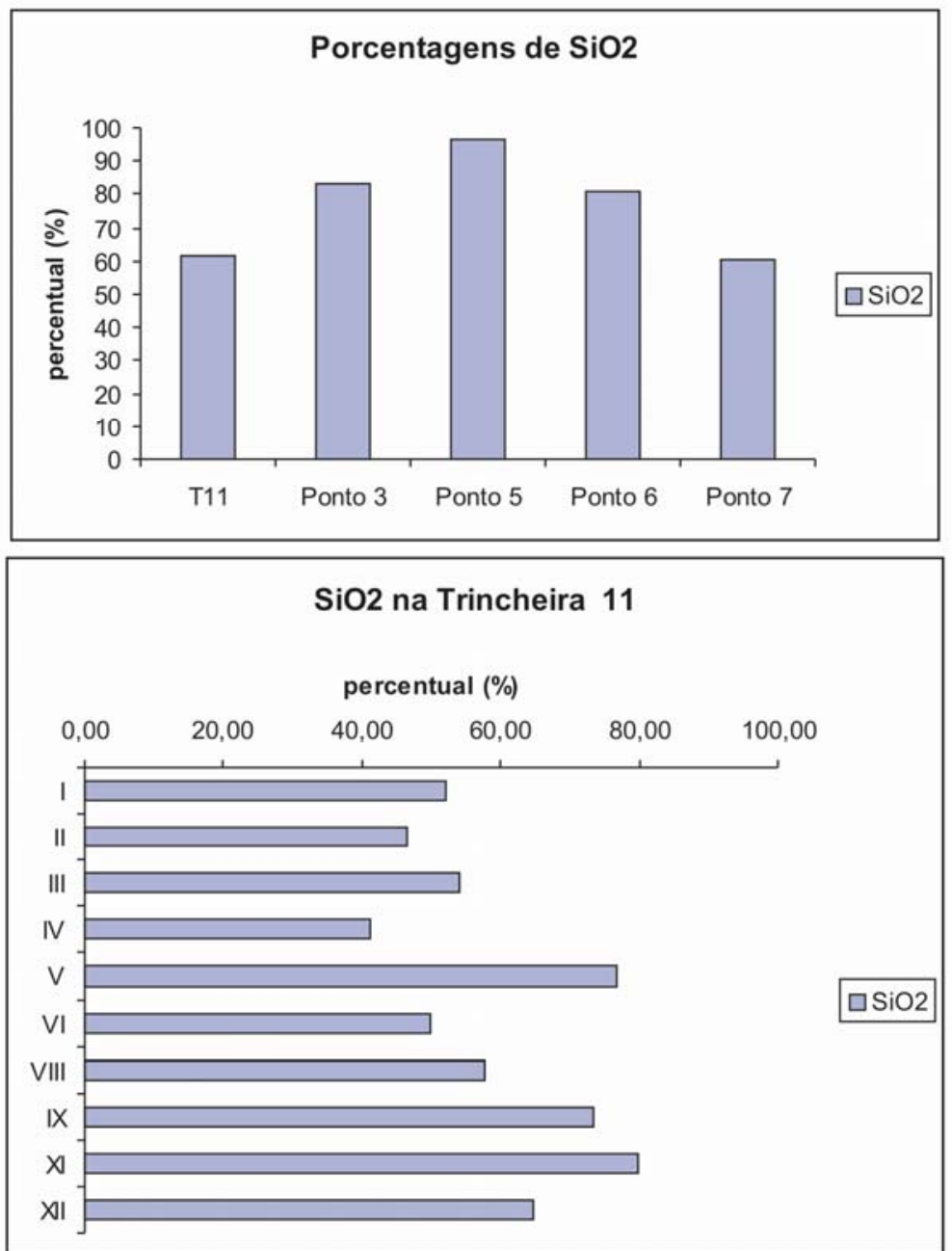

Fig. 23. - Porcentagens de SiO2 na T11 (valor médio para as dez amostras analisadas), fácies lamosa e turfosa das quatro sondagens escolhidas para comparação na área de controle (superior). Porcentagens de $\mathrm{SiO} 2$ ao longo do perfil da T11 (inferior).

$\mathrm{Na}$ figura 24 apresentam-se as porcentagens de elementos maiores e menores, e elementos traço em partes por milhão (ppm) para a T11 e os quatro pontos selecionados da área de controle. Os elementos de maior destaque em termos comparativos foram principalmente $\mathrm{P}$ e $\mathrm{Ca}$, cuja concentração em massa é marcadamente mais alta nos sedimentos arqueológicos, junto com $\mathrm{Sr}$ e $\mathrm{Zn}$. 

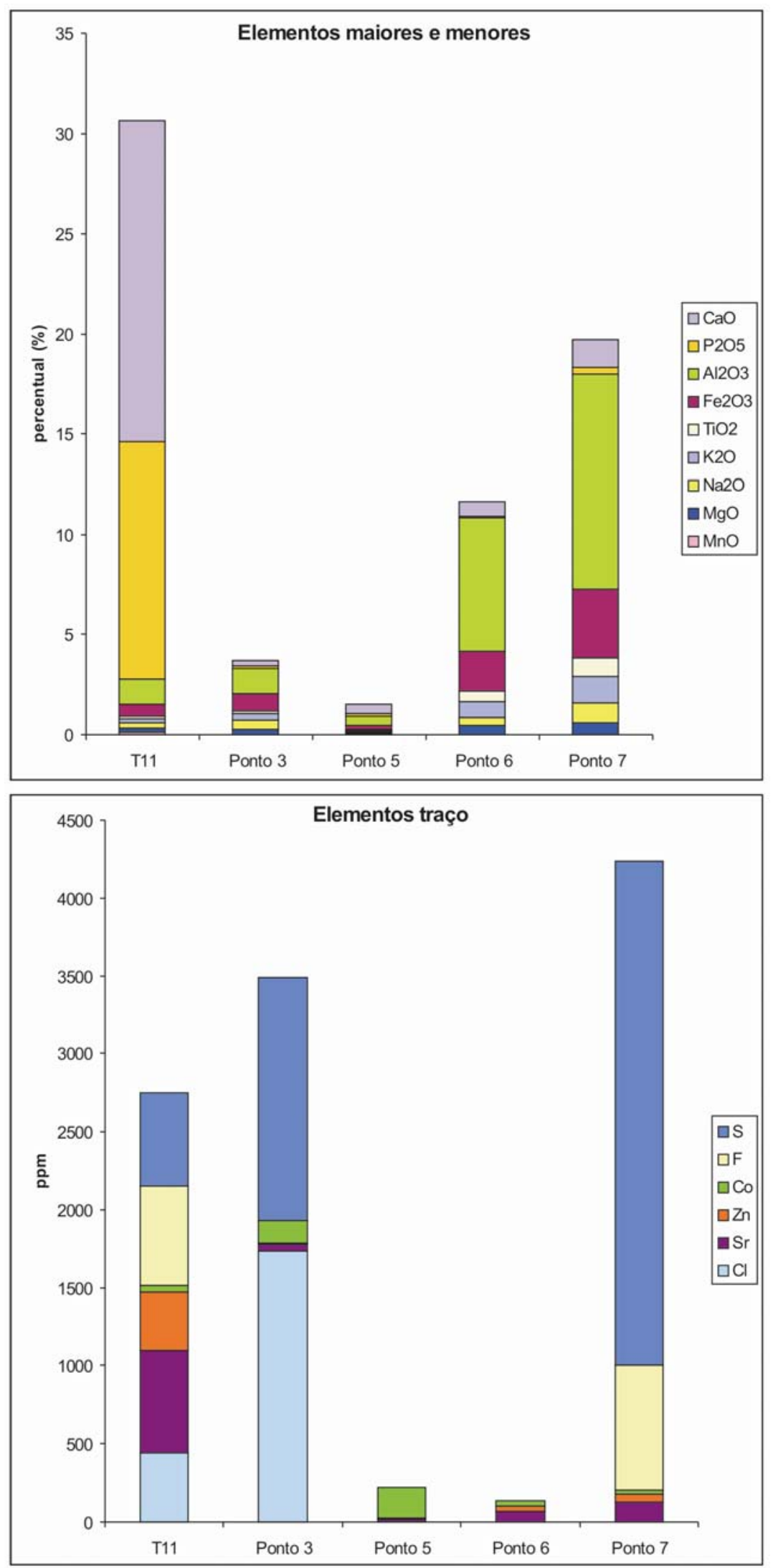

Fig. 24. - Concentrações de elementos maiores e menores (superior) e elementos traço (inferior) na área de controle e na T11 (valor médio para as dez amostras estudadas). Note-se a predominância do $\mathrm{P}, \mathrm{Ca}, \mathrm{Sr}$ e $\mathrm{Zn}$ nos sedimentos arqueológicos. A ausência de $\mathrm{F}$ e $\mathrm{S}$ nos pontos 5 e 6 deve-se a estes elementos apresentarem valores abaixo dos limites de detecção do método utilizado (menor que $300 \mathrm{ppm}$ para o $\mathrm{S}$ e menor que $550 \mathrm{ppm}$ para o F). 
As concentrações de $\mathrm{P}_{2} \mathrm{O} 5$ e $\mathrm{CaO}$ na camada preta e na área de controle são marcadamente distintas. Estes elementos são os de maior representação nos sedimentos arqueológicos (mais de $10 \%$ de $\mathrm{P}_{2} \mathrm{O} 5$ e mais de $15 \%$ de $\mathrm{CaO}$ ), estando nula ou escassamente representados nos sedimentos paleolagunares (em torno de $0,15 \%$ de $\mathrm{P}$ e 0,7\% de Ca). Dos quatro pontos escolhidos na área de controle para comparação, o ponto 7 (turfoso e rico em MO) apresenta as maiores concentrações de estes elementos, embora muito inferiores aos valores obtidos nos sedimentos arqueológicos.

$\mathrm{Na}$ figura 24, também se podem observar as concentrações comparativamente altas de elementos traço como $\mathrm{Sr}, \mathrm{Cl}$ e $\mathrm{Zn}$ na $\mathrm{T} 11$ em relação aos valores na área de controle. Excetuando o alto teor de $\mathrm{Cl}$ no ponto $3(1733 \mathrm{ppm})$, a concentração deste elemento nas demais sondagens é menor que o limite de detecção do método utilizado (menor que $50 \mathrm{ppm}$ ). Também na camada preta o Sr apresenta uma concentração média dez vezes maior que a média encontrada na área de controle (648 vs. 63 ppm), e o valor do Zn é quatorze vezes maior na T11 que na área de controle (379 vs. 26 ppm).

Considera-se que a composição diferencial de ambos os grupos de amostras (camada preta e área de controle), especialmente relacionada com os valores registrados para elementos como $\mathrm{P}, \mathrm{Ca}, \mathrm{Sr}$ e $\mathrm{Zn}$ na camada preta, está vinculada principalmente à ação antrópica que originou os sedimentos arqueológicos. A seguir, discute-se a origem dessas concentrações particulares.

$\mathrm{O} \mathrm{P}$ sob a forma de fosfato $\left(\mathrm{P}_{2} \mathrm{O}_{5}\right)$ tem demonstrado ser especialmente apropriado na caracterização de solos e sedimentos afetados pela ação humana. Os numerosos caminhos pelos quais as pessoas podem adicionar fosfato a um solo ou sedimento geralmente incluem a deposição ou queima de materiais orgânicos e inorgânicos (tecidos animais e de plantas) e de subprodutos metabólicos (matéria fecal, urina) (Proudfoot 1976; Eidt 1977; Sjoberg 1976; Parnell et al. 2002; Holliday 2004; Middleton 2004). O fósforo é introduzido antropicamente num solo ou sedimento tanto na forma de fosfato orgânico como inorgânico e tem a particularidade de persistir no tempo por causa da sua forte fixação, precipitação, baixa solubilidade, oxidação e baixa mobilidade (Cook \& Heizer 1965; Eidt \& Woods 1974; Eidt 1977; Holliday 2004).

O osso é um tecido complexo que consiste em fosfatos de cálcio inorgânicos precipitados numa matriz orgânica de colágeno (Pate \& Hutton 1988: 730). No geral, o osso está composto de $60 \%$ de fosfato de cálcio e $25 \%$ de colágeno; os 5 a $10 \%$ restantes incluem uma combinação de outros minerais como muco-polisacarídeos (açúcares complexos), carbonatos, $\mathrm{Mg}, \mathrm{Na}$ e elementos traço como $\mathrm{Cl}, \mathrm{Fe}, \mathrm{K}, \mathrm{Sr}$, entre 
outros íons de metais (White \& Hannus 1983; Posner et al. 1984; Linse 1992; McCutcheon 1992).

Um dos componentes macroscópicos mais importantes da camada preta são os restos arqueofaunísticos, principalmente de peixe (Nishida 2007). Como há vinculação entre altos valores conjuntos de $\mathrm{P}$ e $\mathrm{Ca}$ em sedimentos arqueológicos e altos conteúdos de ossos (Cook \& Heizer 1965; Schuldenrein 1995; Holliday 2004), pode-se supor que os altos valores destes elementos na camada preta deva-se principalmente à presença de ossos. Peixes concentram os maiores valores de $\mathrm{P}$ e Ca nas suas partes não comestíveis, ou seja, nos ossos e na pele (Lehmann et al. 2004).

A porcentagem em massa dos elementos maiores e menores restantes, na T11, é consideravelmente menor que os valores de $\mathrm{SiO}_{2}, \mathrm{P}_{2} \mathrm{O}_{5}$ e $\mathrm{CaO} . \mathrm{Na}$ área de controle, o ponto 5 parece estar quase totalmente composto por $\mathrm{SiO}_{2}$, derivado das areias terrígenas. Já nos pontos 3, 6 e 7 destaca-se, além da esperada proporção dominante de $\mathrm{SiO}_{2}$, o $\mathrm{Al}_{2} \mathrm{O}_{3}$ juntamente com o $\mathrm{Fe}_{2} \mathrm{O}_{3}$, seguido em ordem de concentração descrescente por $\mathrm{K}_{2} \mathrm{O}, \mathrm{Na}_{2} \mathrm{O}, \mathrm{CaO}, \mathrm{TiO}_{2}$ e $\mathrm{MgO}$. Este conjunto de óxidos, junto com elementos traço como $\mathrm{S}, \mathrm{Sr}, \mathrm{Zn}, \mathrm{Cl}$ e Co, está geralmente vinculado à presença de compostos orgânicos nos sedimentos, o que é coerente com os valores registrados de MO para estes três pontos na área de controle (fig. 25).

Quanto ao $\mathrm{Al}_{2} \mathrm{O}_{3}$, sua concentração pode estar relacionada à presença de aluminossilicatos presentes nos solos e sedimentos da região principalmente na forma de argilominerais. De fato, os pontos 6 e 7, onde se registraram as maiores concentrações desse elemento, apresentaram também as maiores porcentagens de argila nas análises granulométricas. Destaca-se que, na T11, a concentração de $\mathrm{Al}_{2} \mathrm{O}_{3}$ em massa, embora consideravelmente menor que a dos pontos $6 \mathrm{e} 7$, é semelhante à do ponto 3 e maior que a do ponto 5 .

Vários dos elementos encontrados em ambos os conjuntos de amostras ( $\mathrm{Na}, \mathrm{Mg}$, $\mathrm{Mn}, \mathrm{Fe}, \mathrm{Cl}, \mathrm{K}, \mathrm{Sr}, \mathrm{Zn}$ ) têm a particularidade de serem pouco diagnósticos da origem, pois podem ser encontrados nos tecidos ósseos (Griffith 1980; Lucas \& Prévôt 1991; Parnell et al. 2002; Holliday 2004), nos restos vegetais e produtos da sua decomposição (Barba \& Ortiz 1992; Barba et al. 1995; Middleton \& Price 1996; Fernandez et al. 2002; Parnell et al 2002b; Costa et al. 2004; Homsey \& Capo 2006), e em diversos minerais.

Pelo alto conteúdo arqueofaunístico da camada preta (aproximadamente 50\%), a concentração destes elementos poderia estar principalmente relacionada à presença dos 
ossos. Porém, deve-se levar em consideração que os restos arqueofaunísticos que compõem este depósito arqueológico têm sofrido alterações vinculadas à queima e ao intemperismo. Estas alterações podem ter provocado a lixiviação dos seus componentes mais leves até níveis inferiores ou mesmo sua saída do sistema durante a queima. De fato, análises semiquantitativas realizadas ao microscópico eletrônico de varredura (MEV) com espectrometria de energia dispersiva (EES), demonstraram que a composição dos ossos neste depósito arqueológico está principalmente caracterizada pela presença de $\mathrm{Ca}, \mathrm{P}, \mathrm{C}, \mathrm{Na}, \mathrm{Mg}$ e Fe unicamente. Portanto, grande parte da concentração destes elementos deve estar provavelmente vinculada à alta quantidade de ossos neste depósito; enquanto que todos os demais elementos químicos determinados poderiam estar vinculados à presença de minerais, restos vegetais e produtos da sua decomposição e queima.

O descarte de restos orgânicos está geralmente vinculado a grandes quantidades de MO, valores elevados de P, K, Mg e elementos traço (Barba \& Ortiz 1992; Barba et al. 1995; Middleton \& Price 1996; Fernandez et al. 2002; Parnell et al. 2002; Holliday 2004). O teor de MO na T11 apresentou média de 1,6\%, variando de $0,18-0,98 \%$, na arqueofácies 2 e subfácies 2.1, para 1,43\% na arqueofácies 3 e 1,84-3,64\% na subfácies 3.1. Estas porcentagens podem ser consideradas baixas em relação aos valores registrados na área de controle (figs. 25 e 26).

A MO atual não é, portanto, um componente tão significativo na camada preta quanto nos sedimentos paleolagunares. Porém, ela pode ter sido mais relevante na época de acumulação dos sedimentos arqueológicos e ter sido lixiviada pósdeposicionalmente, ou destruída pela queima que claramente sofreram estes sedimentos (evidenciada pela presença de carvões). Altos valores de $\mathrm{P}$ e baixas porcentagens de MO (<1\%) são característicos de áreas de queima, já que as altas temperaturas destroem a MO e transformam o $\mathrm{P}$ orgânico em inorgânico com alta capacidade de fixação (Sanchez \& Cañabate 1998: 155). Porém, a destruição da MO não significa a desaparição de todos os seus componentes, visto que alguns dos seus elementos $(\mathrm{Ca}, \mathrm{S}$, $\mathrm{P}, \mathrm{Mg}$ ) têm a capacidade de permanecer nas cinzas produzidas após a queima dos materiais vegetais (Lyon \& Buckman 1994; Middleton \& Price 1996). Não obstante, deve-se lembrar que a composição química das cinzas varia também em função das diferentes temperaturas de queima. Metais como $\mathrm{Al}, \mathrm{Fe}, \mathrm{Mg}$ e $\mathrm{Mn}$ tendem a aumentar consideravelmente até temperaturas próximas a $1000^{\circ} \mathrm{C}$ (Etiégni \& Campbell 1991). 
Dietas baseadas na ingestão de peixes, frutos do mar, coquinhos e legumes deixam altos teores de $\mathrm{Zn}, \mathrm{Sr}$, Mn e Mg nos sedimentos arqueológicos devido a estes alimentos serem ricos em tais elementos (Grifith 1980; Costa et al. 2004; Homsey \& Capo 2006). Da mesma maneira, os teores de $\mathrm{Zn}$ e Sr no esqueleto dos animais variam em função da dieta e tendem a aumentar durante a diagênese dos ossos (Lucas \& Prévôt 1991: 397) Portanto, as notáveis quantidades destes metais nos sedimentos da camada preta podem estar vinculadas à dieta rica em peixes e moluscos destas comunidades (talvez também em coquinhos das palmeiras da região), cujos restos eram depositados no sambaqui.

Nas sondagens na área de controle, pelo contrário, as porcentagens comparativamente altas de MO estimadas, a ausência de restos ósseos, as baixas porcentagens de $\mathrm{CaO}$ e a quase nula presença de $\mathrm{P}_{2} \mathrm{O}_{5}$ indicam que a concentração destes elementos está ali provavelmente vinculada principalmente à alteração de restos vegetais, processos pedogênicos e deposição atmosférica, juntamente com a matéria prima geológica. Portanto:

Os teores de $\mathrm{P}_{2} \mathrm{O}_{5}, \mathrm{CaO}$ e provavelmente $\mathrm{Sr}$ e $\mathrm{Zn}$ na camada preta relacionam-se à alta proporção de ossos de peixe na sua composição. Enquanto isso, na área de controle, as propriedades químicas estão principalmente relacionadas à matéria prima geológica e à decomposição de restos vegetais e a ciclagem natural dos elementos pelas raízes da vegetação estabelecida na superfície dos depósitos.

$\mathrm{Na}$ figura 25, apresentam-se as porcentagens de $\mathrm{MO}, \mathrm{C}$ e as concentrações de $\mathrm{N}$ (em ppm) nas arqueofácies da T11 e na fácies lamosa e turfosa (horizonte A) dos pontos escolhidos para comparação na área de controle. A partir da observação dos três diagramas pode-se notar como nos sedimentos paleolagunares os teores de MO estão associados às concentrações de $\mathrm{C}$ e $\mathrm{N}$. Isto decorre do fato de que a fonte principal de MO num solo ou sedimento, os tecidos vegetais e os produtos da sua decomposição (húmus), estão compostos por água e por matéria seca composta majoritariamente por $\mathrm{C}$ (componente principal da MO), N, O e H (90\% da fração seca), junto com matéria mineral em menores quantidades (S, P e Ca) (Lyon \& Buckman 1994).

Sedimentos ricos em MO apresentam concentrações de $\mathrm{C}$ em torno de $10 \%$ e de $\mathrm{N}$ por volta de 2500-3500 ppm. Efetivamente, nos pontos 3 e 7 na área de controle, as altas porcentagens de MO registradas (na ordem de 20\%) correspondem com os teores de $\mathrm{C}$, e $\mathrm{N}$ determinados (em torno de 7\% de $\mathrm{C}$ e 4500 ppm de $\mathrm{N}$ ) (fig. 25). 


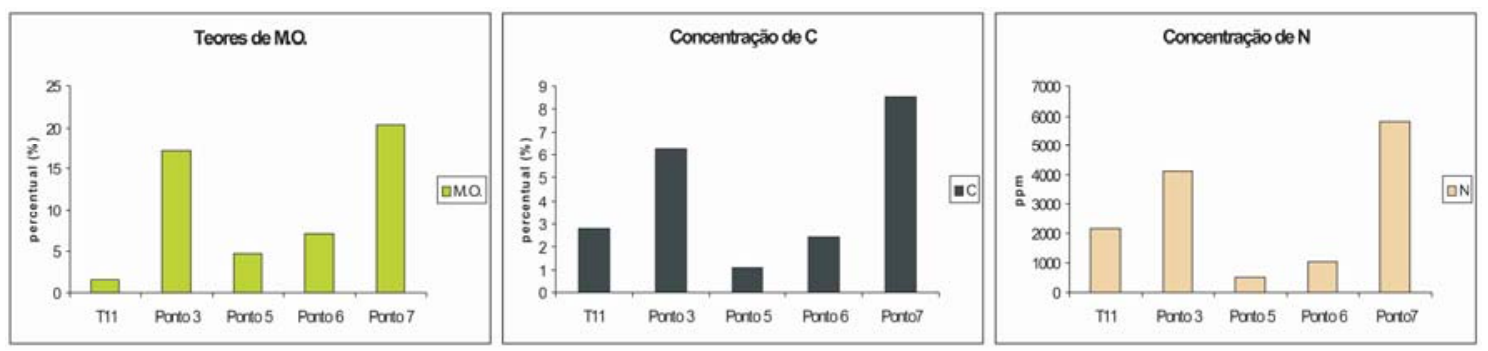

Fig. 25. - Porcentagens de MO, C total, e $\mathrm{N}$ total (em ppm) para a área de controle e T11 (valor médio para as dez amostras estudadas). Note-se como nos sedimentos paleolagunares a porcentagem de MO ultrapassa os valores de $\mathrm{C}$ total, ao contrário do que acontece na camada escura.

Nos sedimentos arqueológicos da T11 a situação é a oposta, já que MO e C têm porcentagens semelhantes e a concentração de $\mathrm{C}$ é levemente maior que a de $\mathrm{MO}$, embora não supere os 3\%. As concentrações de C e N na T11 chegam a alcançar valores superiores aos encontrados nos pontos 5 e 6 , que efetivamente possuem maiores teores de MO (fig. 25). Isto estaria indicando que nos sedimentos arqueológicos da camada preta só uma fração menor da concentração de $\mathrm{C}$ e $\mathrm{N}$ totais estaria relacionada com a MO presente.

As diferenças entre $\mathrm{MO}, \mathrm{C}$ e $\mathrm{N}$ são também observadas ao longo do perfil da T11 (fig. 26), no qual as porcetagens de $\mathrm{C}$ e $\mathrm{N}$ permanecem relativamente constantes, embora a $\mathrm{MO}$ varie entre valores comparativamente menores à porcentagem de $\mathrm{C}$ total.
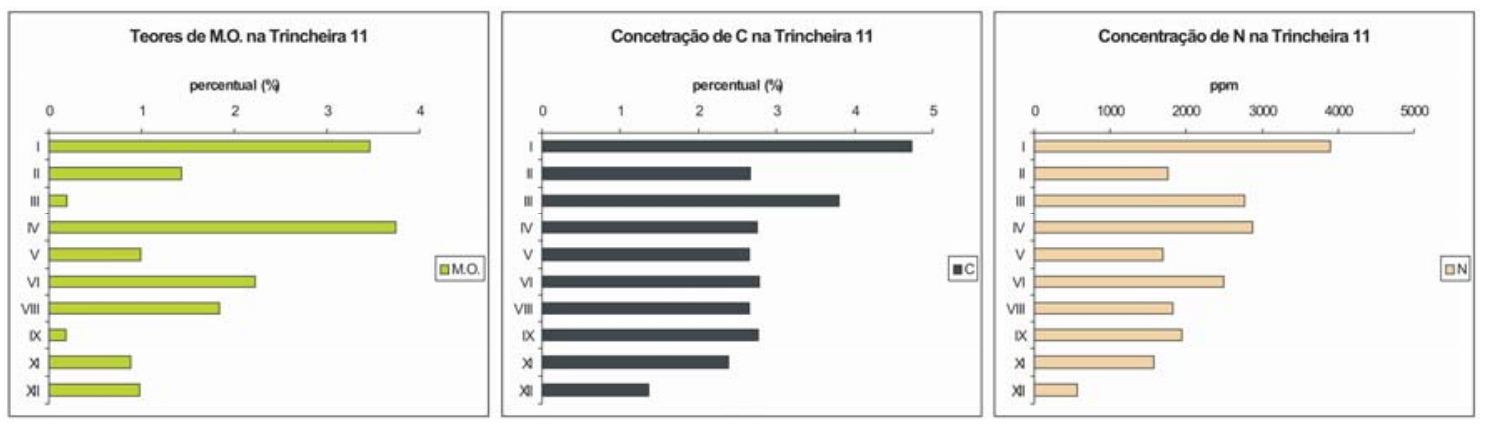

Fig. 26. - Distribuição das concentrações de MO (\%), C total (\%) e N total (ppm) ao longo da seção vertical da T11.

Portanto, a maior parte do $\mathrm{C}$ e $\mathrm{N}$ presentes na $\mathrm{T} 11$ está certamente vinculada a um outro material, especialmente rico em estes elementos, que caracteriza todas as unidades amostradas verticalmente e cuja concentração não está exclusivamente vinculada com o conteúdo de MO

Tomando o C total como referência, as formas nas quais este elemento pode estar representado nos sedimentos são, além da forma orgânica (MO e humus), os carbonatos 
(composto inorgânico), a grafita e o carvão (formas elementais) (Hesse 1971). Parte do conteúdo de $\mathrm{C}$ pode estar efetivamente relacionada com a forma inorgânica contida nos ossos, mas isto não explica os altos valores de $\mathrm{N}$ e $\mathrm{S}$ também registrados na T11.

Portanto, seria a forma elemental do $\mathrm{C}$ a responsável pela concentração de $\mathrm{C}$ na camada preta, especialmente representada pelos carvões produzidos pela queima de material vegetal, que possuem tanto $\mathrm{N}$ como $\mathrm{S}$ na sua composição, junto com vários outros nutrientes (Lehmann et al. 2003: 345); isto coincide com as quantidades consideráveis de carvão reconhecidas macroscopicamente em todas as frações granulométricas das arqueofácies identificadas.

Os carvões, partículas orgânicas pretas e opacas, têm recebido uma variedade de denominações em função da técnica e da disciplina empregada. Genericamente são chamados de carbono preto (black carbon), produzido pela combustão incompleta de materiais orgânicos (combustíveis fósseis, madeira e vegetação) (White \& Hannus 1981: 363; Schmidt \& Noack 2000: 777).

Este carbono preto se forma em reações exotérmicas a temperaturas entre $280^{\circ}$ e $500^{\circ} \mathrm{C}$. Durante a queima, parte dos materiais vegetais volatiliza formando partículas sub-micronesimais na fase gasosa (que recondensam em fuligem altamente grafitizada), e outra parte é queimada (carbonizada), restando partículas de mais de dezenas de micrômetros (Dimbleby 1967; Rodriguez Ariza 1993; Schmidt \& Noack 2000).

O carvão propriamente dito é o produto da queima de madeira. Na medida em que a temperatura aumenta, os elementos estruturais maiores da planta (hemicelulose, celulose e lignina) se quebram enquanto $\mathrm{CO}, \mathrm{CO}_{2}$ e outros gases são liberados. A evaporação destes gases resulta na condensação do esqueleto de $\mathrm{C}$ e na aromatização, $\mathrm{o}$ que resulta na formação de camadas de tipo grafítico (Cohen-Ofri et al. 2006).

O carvão depositado na superfície de um solo ou sedimento, embora muito susceptível à erosão pelo vento e água, devido a sua fragilidade, é considerado de natureza inerte e indestrutível do ponto de vista químico (exceto pela queima); por não oferecer uma fonte de alimentação para os microorganismos, permanece sem mudar indefinidamente (Dimbleby 1967: 100; Schmidt \& Noack 2000: 780; De Souza Falcão et al. 2003: 260). Porém, a pretendida natureza inerte dos carvões é ainda tema de discussão e estudos recentes têm demonstrado que ele é passível de alterações diagenéticas (Cohen-Ofri et al. 2006).

$\mathrm{Na}$ figura 26, pode-se observar como as unidades arqueológicas que apresentam os menores teores de MO na T11 simultaneamente contêm as maiores concentrações de C 
(unidades III, V, IX e XI). Estas unidades correspondem às arqueofácies 2 e subfácies 2.1, identificadas em campo como compostas por materiais queimados (ossos queimados e carvões na arqueofácies 2 , junto com cinzas na subfácies 2.1.).

Para esclarecer mais esta relação entre a MO e a concentração de C na T11, converteram-se as porcentagens de $\mathrm{MO}$ em porcentagens aproximadas de $\mathrm{C}$ orgânico total. Desta maneira, conseguem se observar melhor as diferentes proporções entre as diversas formas de $\mathrm{C}$ nas amostras. Para converter a porcentagem de $\mathrm{MO}$ determinada pelo método de oxidação com $\mathrm{H}_{2} \mathrm{O}_{2}$ em $\mathrm{C}$ orgânico total, realizam-se os seguintes cálculos, baseados em Hesse (1971):

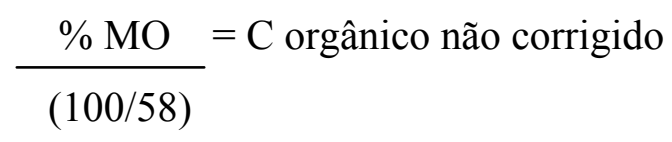

C orgânico não corrigido $\mathrm{x}(100 / 87)=\mathrm{C}$ orgânico total

Porém, cabe ressaltar que o método de oxidação por $\mathrm{H}_{2} \mathrm{O}_{2}$ oferece uma estimativa expedita das porcentagens de MO, pelo qual qualquer calculo realizado sobre estes valores deve ser tomado como uma aproximação à realidade.

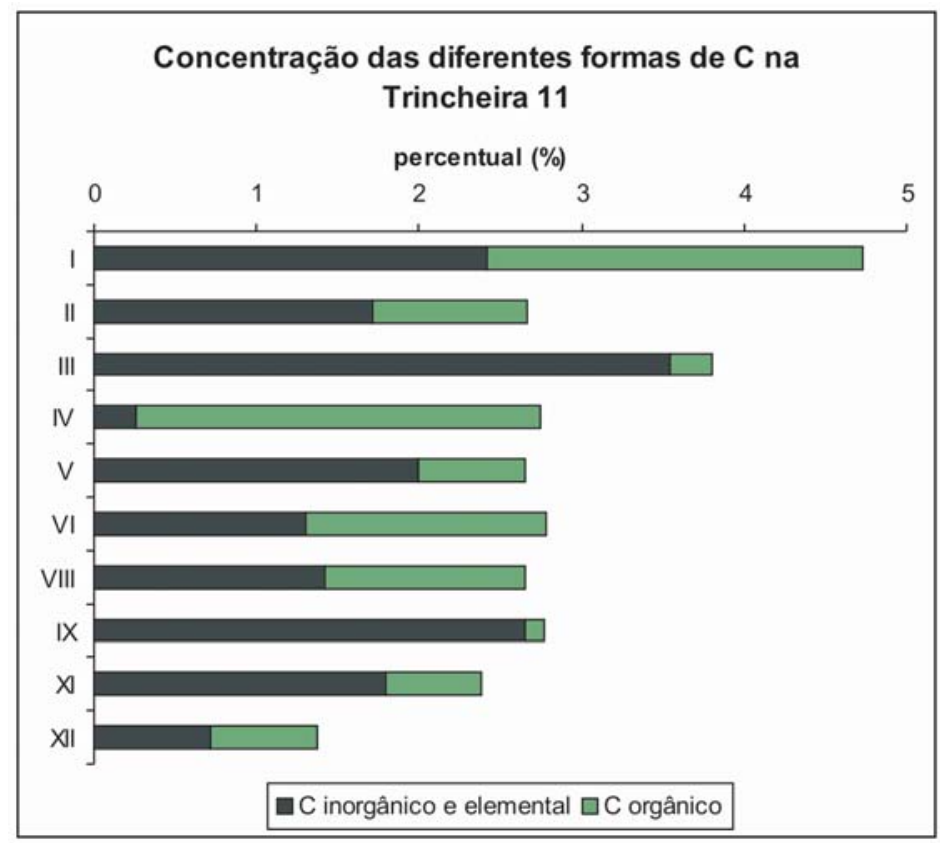

Fig. 27. - Porcentagens de C orgânico e C inorgânico e elementar para as diferentes arqueofácies na T11. 
$\mathrm{Na}$ figura 27, apresentam-se as porcentagens aproximadas calculadas de C orgânico e C inorgânico e elementar para cada unidade amostrada na T11. Este gráfíco permite confirmar como as unidades correspondentes às arqueofácies 2 e subfácies 2.1 efetivamente apresentam as menores porcentagens de C orgânico e os maiores valores de C inorgânico e elementar. Nestas arqueofácies e subfácies, o C elementar estaria representado pelos carvões, e o $\mathrm{C}$ inorgânico estaria vinculado à presença de cinzas, já que as cinzas produzidas pela queima de madeira estão formadas predominantemente por cristais de carbonato de cálcio (Brochier 1983a; 1983b; 2002; Canti 2003). No tópico 5.5.7, discussões adicionais sobre as concentrações relativas de cinzas e carvões na T10 e T11 serão apresentadas.

Portanto:

Levando em consideração a presença constante de C elementar e N no perfil, e em vista do observado em campo durante a flotação dos sedimentos para coleta de amostras antracológicas $^{8}$, os carvões representam um componente constante na camada preta, ainda que sua concentração e granulometria varie nas diferentes arqueofácies identificadas.

$\mathrm{Na}$ figura 28, apresentam-se as concentrações dos elementos maiores, menores e traço ao longo do perfil da T11. Neste gráfico, pode-se observar que as porcentagens de $\mathrm{P}_{2} \mathrm{O}_{5}$ e CaO também tendem a diminuir na arqueofácies 2 e subfácies 2.1 , compostas por materiais queimados. Isto estaria corroborando a menor quantidade de restos arqueofaunísticos que já tinha sido identificada nestas unidades após o tratamento com $\mathrm{HCl}$ (ver tópico 5.2.3).

Pelo demais, os diagramas da figura 28 permitem observar como a composição química das diferentes unidades amostradas permanece relativamente a mesma ao longo do perfil, mostrando unicamente variações importantes nos teores de $\mathrm{P}_{2} \mathrm{O}_{5}$ e $\mathrm{CaO}$, com mudanças muito sutis nas concentrações dos demais elementos, provavelmente vinculadas aos carvões e à M.O presentes.

\footnotetext{
${ }^{8}$ Trabalho que está sendo realizado no projeto temático pela Dra. Rita Scheel-Ybert.
} 
De esta maneira, a análise química multi-elemental permite concluir que:

As arqueofácies identificadas na T11 apresentam aproximadamente a mesma composição química em termos qualitativos e quantitativos. Alterações importantes nas porcentagens de $\mathrm{P}_{2} \mathrm{O}_{5}, \mathrm{CaO}, \mathrm{C}$ orgânico e $\mathrm{MO}$, observadas na arqueofácies 2 e subfácieß 2.1, são condizentes com seu menor conteúdo arqueofaunístico e com sua composição majoritária a base de partículas resultantes da queima vegetal (carvão). 

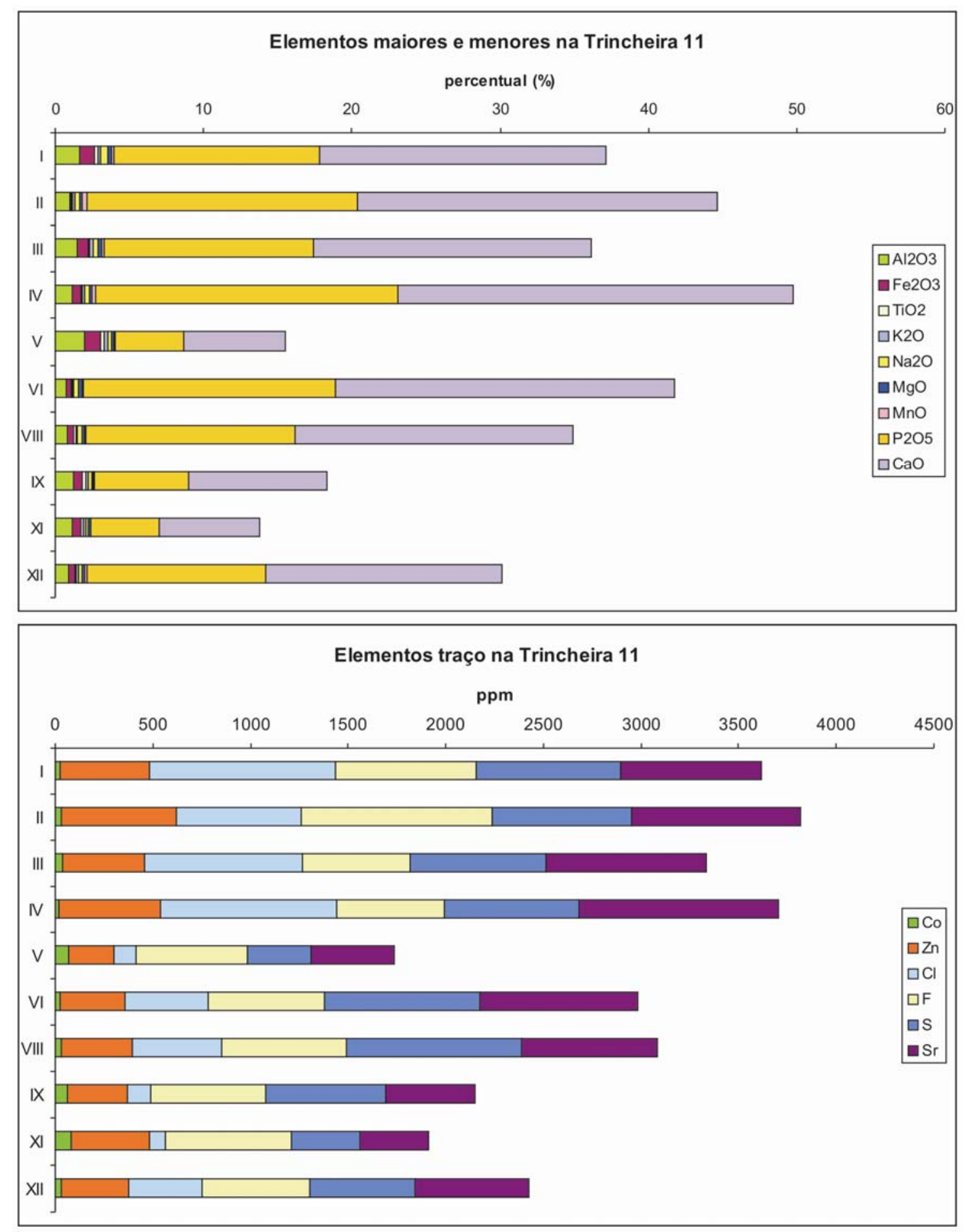

Fig. 28. - Concentração de elementos maiores e menores (superior) e elementos traço (inferior) na T11. 


\section{4. - Mineralogia da fração argila}

A composição mineralógica da fração argila é uma pripriedade significativa na caracterização de arqueofácies. Ela pode outorgar informações relativas à relação entre as distintas arqueofácies identificadas, aos processos intempéricos e pedogênicos atuantes no local, à influência antrópica na adição ou alteração dos componentes arqueossedimentares e à possível semelhança entre sedimentos arqueológicos e naturais.

Para conhecer minerais de argila existentes nas arqueofácies identificadas na T11, foram analisadas amostras correspondentes às arqueofácies 1 e 2, e às subfácies 2.1 e 3.1.; para efeito de comparação, analisaram-se também duas amostras correspondentes à facies lamosa dos pontos 1 e 3 da área de controle. 

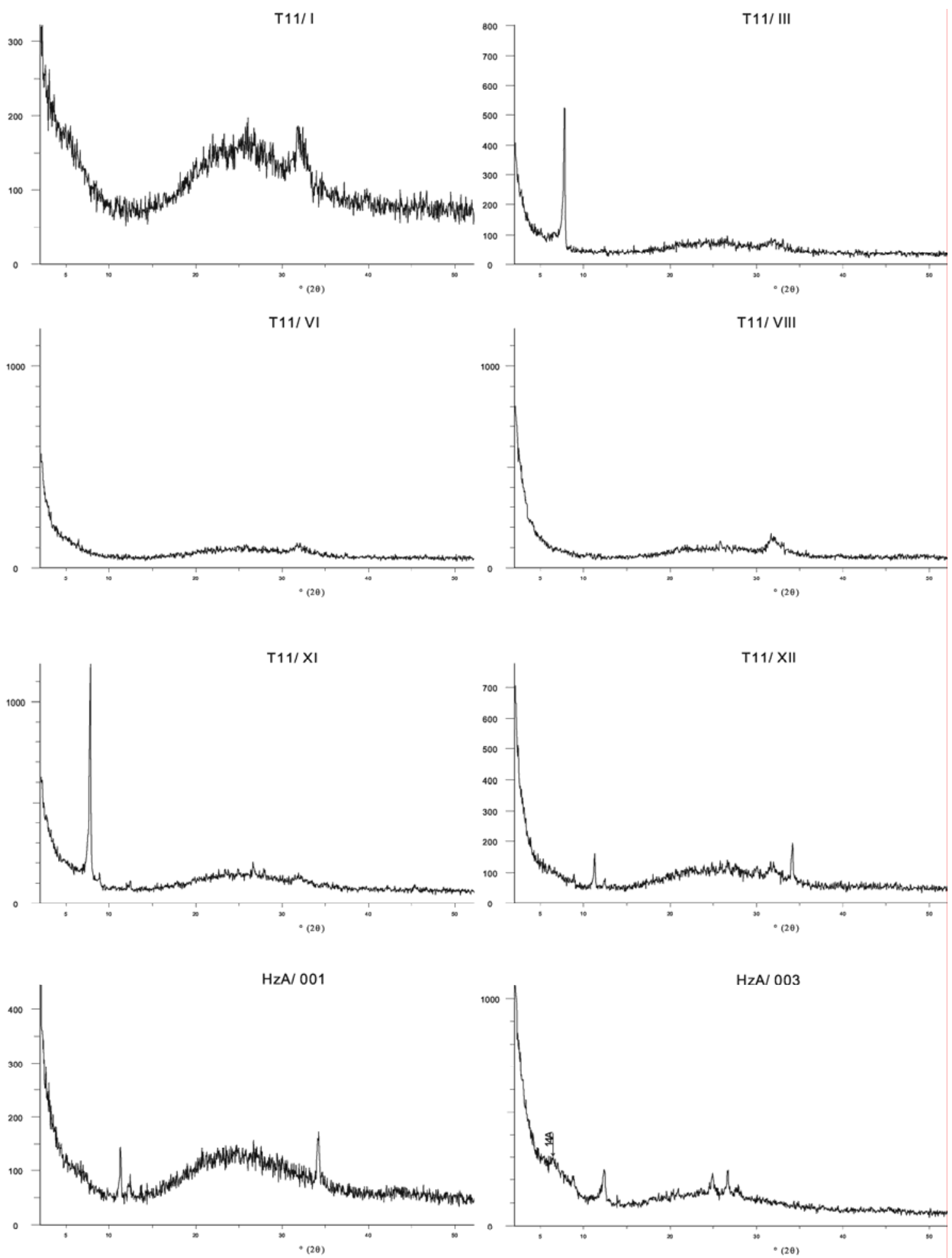

Fig. 29. - Difratogramas dos minerais de argila nas arqueofácies da T11 e nos pontos 1 e 3 da área de controle. T11/I: arqueofácies 1; T11/III: arqueofácies 2; T11/VI: subfácies 3.1; T11/VIII: subfácies 3.1; T11/XI: subfácies 2.1; T11/XII: subfácies 3.1. 
$\mathrm{Na}$ figura 29, apresentam-se os difratogramas correspondentes aos materiais analisados. Da leitura destes gráficos extrai-se o seguinte conjunto de informações sobre a composição mineralógica da fração argila nas arqueofácies analisadas: na unidade I (arqueofácies 1) identificou-se apenas a presença de apatita; na unidade III (arqueofácies 2) apresenta apatita e um pico correspondente a pirofosfato de sódio, componente intrusivo utilizado na defloculação das amostras; as unidades VI e VIII (subfácies 3.1) só apresentam apatita; a unidade XI (subfácies 2.1) apresenta apatita juntamente com mica, caulinita e pirofosfato intrusivo; por último, a unidade XII (subfácies 3.1) também apresenta apatita junto com mica e caulinita.

As amostras da área de controle correspondententes ao Ponto 1 contêm caulinita e pirofosfato de sódio, e a correspondente ao Ponto 3 contém caulinita, illita e um pico de $14 \AA$ que pode corresponder tanto a esmectita como a clorita. Para diferenciar entre estes dois últimos componentes qual deve ser realizado o tratamento com glicerol e aquecimento.

Em todos os difratogramas da figura 29 , tanto da camada preta arqueológica como da área de controle, pode-se observar, junto com os materiais cristalinos, a presença de um material amorfo ou de baixa cristalinidade. Este material pode estar relacionado com a lâmina de vidro na qual foram preparadas as amostras, ou com a presença de um componente sedimentar efetivamente amorfo ou de cristalinidade baixa..

Portanto, da apreciação dos gráficos da figura 29 extraem-se duas conclusões fundamentais sobre a composição da camada escura:

A apatita é o mineral de maior destaque na fração argila; à exceção das subfácies localizadas próximas à base do perfil, a camada preta não possui aparentemente filossilicatos na sua composição.

Encontrar apatita na fração argila da camada escura não resulta surpreendente. Este mineral constitui o componente inorgânico principal dos ossos, que, por sua vez, são o componente antrópico mais conspícuo dos sedimentos arqueológicos da camada escura. Os restos arqueofaunísticos provavelmente já começaram a sofrer os efeitos do intemperismo assim que foram depositados, ainda na época em que o sistema cultural sambaquieiro era ativo. Os processos intempéricos físicos e químicos operando no local de deposição são capazes de provocar a separação e destruição dos componentes microscópicos, orgânicos e inorgânicos (Behrensmeyer 1978: 153). A completitude 
estrutural e mineralógica dos ossos teria sido alterada progressivamente pela ação dos agentes intempéricos, liberando e reprecipitando fosfato, na forma de apatita, na fração argila.

Como os minerais de apatita (hidroxiapatita, fluorapatita e cloroapatita) são isomorfos (Posner et al. 1984), não é possível diferenciar entre eles, de modo seguro, apenas com base em difratometria de raios-X. Portanto, a partir desta análise sabe-se que na camada preta existe mineral do grupo da apatita, embora não se possa determinar qual isomorfo do grupo está efetivamente presente, tampouco em que quantidade. $\mathrm{O}$ mineral do osso é referido indistintamente na literatura como hidroxiapatita $\left(\mathrm{Ca}_{5}\left(\mathrm{PO}_{4}\right)_{3}(\mathrm{OH})\right)$ ou hidroxiapatita carbonatada (antiga "dahlita", nome não referendado pela International Mineralogical Association; $\mathrm{Ca}_{5}\left(\mathrm{PO}_{4}, \mathrm{CO}_{3}\right)_{3}(\mathrm{OH})$ ) (Pate \& Hutton 1988; Linse 1992; McCutcheon 1992; White \& Hannus 1993; Steiner et al. 1995; Karkanas et al. 2000; Hedges 2002; Berna et al. 2004; Trueman et al. 2004; Smith et al. 2007). A hidroxiapatita pura é unicamente encontrada em rochas ígneas formadas a altas temperaturas, sendo que as formas de hidroxiapatita de baixa temperatura são sempre carbonatadas (Berna et al. 2004: 877). Portanto, os ossos compõem-se, em termos gerais, por hidroxiapatita, a qual pode conter carbonatos na sua composição, tanto na estrutura cristalina como adsorvidos em superfície (Posner et al. 1984). O grau de carbonatação, entretanto, permanece incerto, já que depende de vários fatores atuando na geração dos tecidos ósseos.

O intemperismo do mineral que compõe o osso inicia-se pela formação de ácidos orgânicos e carbônicos resultantes da decomposição microbial do colágeno. Uma vez formados, estes ácidos e outros ácidos orgânicos, inclusive húmicos, eventualmente presentes no solo ou sedimento, aceleram a degradação do próprio colágeno, cuja decomposição é mais rápida que a da fração inorgânica dos ossos. $\mathrm{O}$ decaimento do colágeno provoca a dissolução e transformação dos cristais de hidroxiapatita, na dependencia das condições de $\mathrm{pH}$ e do regime hidrológico do local de deposição (Gordon \& Buikstra 1981; White \& Hannus 1983; Linse 1992; Berna et al. 2004; Trueman et al. 2004; Smith et al. 2007). Estas duas variáveis, pH e regime hidrológico, são os fatores controladores das mudanças diagenéticas sofridas pelos restos arqueofaunísticos e pela dissolução e remoção da hidroxiapatita.

A hidroxiapatita dos ossos é relativamente insolúvel a pH básico (acima de 7,6$8,1)$ e aumenta sua solubilidade rapidamente conforme as condições ficam progressivamente mais ácidas; recristaliza a $\mathrm{pH}$ neutro $(7-7,5)$ e forma fosfatos de $\mathrm{Al}$ 
insolúveis a pH ácido (menor que 7) (White \& Hannus 1983; Lucas \& Prévôt 1991; Berna et al. 2004).

Em condições neutras a ácidas, o mineral dos ossos é facilmente dissolvido, e se o regime hidrológico do depósito for intenso a dissolução e remoção dos fosfatos será considerável. Se as condições de $\mathrm{pH}$ se mantêm, os fosfatos em solução em meio ao sedimento podem reprecipitar e recristalizar in situ formando um mineral fosfático autígeno, amorfo ou cristalino. Este mineral pode ocorrer na forma de agregados individuais ou como encobrimento dos grãos que compõem sua fração grossa (Goldberg \& Nathan 1975; Lucas e Prévôt 1991; Courty \& Fedoroff 2002; Trueman et al. 2004).

Levando em consideração a liberação de ácidos pela degradação do colágeno dos ossos, que compõem a camada preta, pode-se supor que as condições originais no momento de deposição antrópica teriam sido provavelmente neutras a ácidas. Como a camada preta se comporta como um sistema aberto, a presença de $\mathrm{CO}_{2}$ atmosférico teria atuado como fonte de ácido para igualmente induzir à dissolução da hidroxiapatita dos ossos. A alta porosidade da camada preta favorece a intensa passagem de água e a boa drenagem, o que reduz os períodos de saturação e aumenta a eficiência da percolação como mecanismo para a remoção dos fosfatos. Estes fosfatos podem ter precipitado e recristalizado como apatita autígena na forma de neoformações fosfáticas (cripto)cristalinas (as quais podem ser denominadas descritivamente, seguindo o poadrão da nomenclatura de Folk (1959) como fosfomicrita).

Medições do $\mathrm{pH}$ atual da camada preta na T10 mostram condições alcalinas a neutras nestes sedimentos ( $\mathrm{pH}$ entre 7,0 e 7,5) (Nishida 2007). Estas condições são especialmente favoráveis para que o mineral do osso reprecipite como apatita autígena. Determinar as condições de $\mathrm{pH}$ original do momento de deposição destes sedimentos arqueológicos só se pode conseguir através de evidências indiretas. Neste caso, a presença de minerais autígenos, que se formam sob condições específicas de $\mathrm{pH}$ e percolação de água, permite a reconstrução aproximada das condições químicas que prevaleceram na camada escura no momento da sua formação (Karkanas et al. 2000; Berna et al. 2004). Porém, estes minerais autígenos não são necessariamente estáveis e podem igualmente sofrer dissolução e recristalização no caso de uma mudança nas condições químicas do sedimento.

No trabalho de iniciação cientifica desenvolvido no IGc-USP por Érico Benedeti Mazini (2007), que consistiu na análise petrográfica de amostras provenientes da camada concrecionada imediatamente inferior à camada preta, observaram-se situações 
deste tipo. Cimentos criptocristalinos de cor castanha envolvem os grãos que compõem o arcabouço da concreção, compostos quartzo (35-40\%) e fragmentos de ossos (20$40 \%$ ) e de conchas carbonáticas de moluscos (10-40\%). Estes cimentos podem apresentar-se na forma de cutículas delgadas (menores que $10 \mu \mathrm{m}$ ) ou crostas espessas em torno dos grãos, bem como intergranulares. Sua composição, identificada como fosfática ao MEV-EED, ter-se-ia originado a partir da dissolução, mobilização e reprecipitação do fosfato presente nos ossos, provindo, por lixiviação, da camada preta.

Deste modo:

O intemperismo sofrido pelos restos arqueofaunísticos, favorecido pelas oscilações de pH e a alta percolação da água, provocaram a formação de fosfomicrita autígena na camada preta, responsável pela identificação, por difratometria de raios-X, de apatita na fração mais fina das arqueofácies identificadas.

Porém, vários dos ossos que compõem a camada escura apresentam evidências claras de queima até o grau de carbonização (transformação em carvão) e calcinação (transformação em óxido de cálcio). Portanto, cabe aqui fazer a seguinte pergunta: como a alteração térmica sofrida pelos ossos influi no seu comportamento perante a ação do intemperismo?

Estudos realizados por Shipman et al. (1984) concluíram que em todas as etapas de aquecimento dos ossos (de 0 a $940^{\circ} \mathrm{C}$ ), a hidroxiapatita permanece como componente mineral predominante. A única diferença observada reside no tamanho dos cristais, que tendem a ficar maiores conforme aumenta gradualmente a temperatura de aquecimento. Esta variação de tamanho é semelhante a que acontece no osso durante o processo de dissolução e recristalização da hidroxiapatita na diagênese (Trueman et al. 2004).

Com a dissolução ou queima da matriz orgânica dos ossos, os cristais da fração mineral tendem a crescer às expensas dos cristais menores destruídos ou dissolvidos, aumentando consideravelmente seu tamanho. Porém, a morfologia superficial dos ossos é diferente em ossos queimados e em ossos que somente sofreram os efeitos do intemperismo; isto permite diferenciar, apenas com o uso do $\mathrm{MEV}$, restos arqueofaunísticos cuja alteração foi produzida pela queima, nos quais os grandes cristais de hidroxiapatita apresentam-se com traços de derretimento (textura superficial globular 
ou vesicular), de restos com alteração gerada pela diagênese (Shipman et al. 1984; McCutcheon 1992; Trueman et al. 2004).

Aqueles ossos que foram queimados previamente à deposição final na camada escura podem ser até mais resistentes ao intemperismo (porém não à pressão física) que os ossos frescos, devido a que o maior tamanho dos seus cristais (adquirido como resultado da queima) os torna menos suscetíveis à dissolução (Karkanas 2000). Uma condição semelhante é adquirida durante o intemperismo ou diagênese prolongados, já que a recristalização do mineral do osso produzida nesses processos acaba aumentando a sua resistência à dissolução (Berna et al. 2004).

A difratometria de raios-X realizada nas arqueofácies da T11 permitiu observar não apenas que a apatita é o componente principal da fração argila, mas também que os filossilicatos estão pouco ou não representados na camada preta. Somente em aquelas unidades localizadas na base do perfil, correspondentes a subfácies 2.1 e 3.1, foram registradas pequenas quantidades de filossilicatos na forma de caulinita e mica.

A ausência de filossilicatos na maior parte do perfil, associada a seu aparecimento em escassas quantidades na base, está provavelmente relacionada à lixiviação dos materiais finos até os níveis inferiores. Como o sambaqui está num nível mais alto que o depósito paleolagunar em relação ao freático, ele está sujeito a gradiente hidrostático maior e mais eluviação.

A escassez de filossilicatos nos sedimentos arqueológicos é reforçada pelos baixos conteúdos de $\mathrm{Al}$ (valor médio de $2 \%$ ), detectado nas análises químicas, em comparação com a área de controle (valor médio entre 5 a 10\%), e pela menor presença de culinita identificada na difratometria.

Pensar que o aquecimento sofrido por estes sedimentos poderia ter transformado os filossilicatos em materiais de baixa cristalinidade também é um argumento discutível. Se tivessem efetivamente existindo grandes quantidades de aluminossilicatos nas amostras antes da queima do sedimento, então os teores de Al deveriam ser consideravelmente maiores atualmente, coisa que não se observa nas análises químicas realizadas. Igualmente a presença de material amorfo, possivelmente alofana, ou filossilicatos de baixa cristalinidade, observa-se tanto na camada preta como nos sedimentos paleolagunares. Portanto, a alofana pode estar representando um componente sedimentar presente em ambos os depósitos e não um material queimado no sítio arqueológico. 
Portanto:

A camada preta pode ter incluído filossilicatos na sua composição, embora atualmente sua presença não seja conspicuamente manifesta. Estes minerais podem ter lixiviado até níveis inferiores pós-deposicionalmente.

\section{5. - Micromorfologia}

A micromorfologia das arqueofácies da camada preta constitui o nexo necessário entre a observação macroscópica realizada em campo, os resultados dos ensaios laboratoriais quantitativos, e a realidade microscópica destes sedimentos arqueológicos. Visa alcançar os seguintes objetivos:

- Ampliar os conhecimentos sobre a composição da camada preta.

- Conhecer as hierarquias e as relações que existem entre seus componentes.

- Reconhecer a ação dos processos pós-deposicionais sofridos.

- Avaliar o grau de influência antrópica na sua trama e composição.

A seguir, apresentam-se as tabelas com as descrições micromorfológicas das arqueofácies e subfácies identificadas na trincheira 10 (tabela 4) e na trincheira 11 (tabela 5). 


\begin{tabular}{|c|c|c|c|c|c|c|c|c|c|c|c|c|c|c|c|c|c|}
\hline \multirow[b]{3}{*}{ Lâmina } & \multirow{3}{*}{$\begin{array}{l}\text { JAB II } \\
\text { Microestrutura }\end{array}$} & \multicolumn{16}{|l|}{ Trincheira 10} \\
\hline & & \multirow[b]{2}{*}{ Porosidade } & \multirow[b]{2}{*}{ 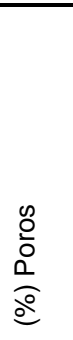 } & \multirow[b]{2}{*}{ Distribuição } & \multirow[b]{2}{*}{$\begin{array}{l}\text { Razão } \\
\text { c/f }\end{array}$} & \multirow[b]{2}{*}{$\begin{array}{l}\text { Padrão de } \\
\text { distribuiçąa }\end{array}$} & \multicolumn{4}{|c|}{$\begin{array}{l}\text { Material } \\
\text { mineral } \\
\text { grosso } \\
\end{array}$} & \multicolumn{3}{|c|}{$\begin{array}{c}\text { Material } \\
\text { orgânico } \\
\text { grosso } \\
\end{array}$} & \multicolumn{4}{|c|}{$\begin{array}{c}\text { Feições } \\
\text { pedológicas }\end{array}$} \\
\hline & & & & & & & $\begin{array}{l}\stackrel{?}{0} \\
\stackrel{0}{0} \\
\stackrel{0}{0}\end{array}$ & 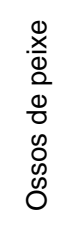 & 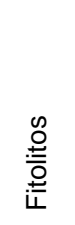 & 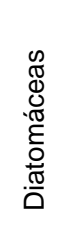 & 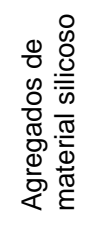 & 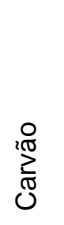 & 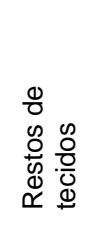 & Micromassa & 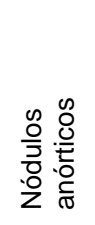 & 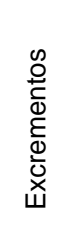 & 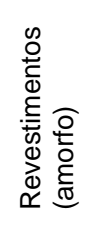 \\
\hline $\begin{array}{l}\text { T10/9 } \\
\text { Unidade I } \\
\text { AF } 1\end{array}$ & $\begin{array}{l}\text { Microaggregads } \\
\text { intergranulares }\end{array}$ & $\begin{array}{l}\text { Vazio de } \\
\text { empacotamento } \\
\text { complexo }\end{array}$ & $\bullet \bullet$ & Aleatória & $60: 40$ & $\begin{array}{l}\text { Enáulica } \\
\text { fina/igual de } \\
\text { espaçamento } \\
\text { fechado/simples }\end{array}$ & $\bullet \bullet$ & $\bullet \bullet$ & & & & • & $\bullet$ & $\begin{array}{l}\text { Amorfa } \\
\text { castanho } \\
\text { escuro } \\
\text { Monomorfa }\end{array}$ & - & 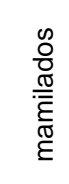 & 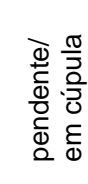 \\
\hline $\begin{array}{l}\text { T10/6 } \\
\text { Superior } \\
\text { Unidade I } \\
\text { AF 1 } \\
\\
\text { Inferior } \\
\text { Unidade II } \\
\text { AF 2 }\end{array}$ & $\begin{array}{l}\text { Microagregados } \\
\text { intergranulares }\end{array}$ & $\begin{array}{l}\text { Vazio de } \\
\text { empacotamento } \\
\text { complexo }\end{array}$ & $\bullet \bullet$ & Aleatória & $60: 40$ & $\begin{array}{l}\text { Enáulica } \\
\text { fina/igual de } \\
\text { espaçamento } \\
\text { fechado/ } \\
\text { simples }\end{array}$ & $\bullet \bullet$ & $\bullet \bullet$ & & & & $\bullet \bullet$ & $\bullet$ & $\begin{array}{l}\text { Amorfa, } \\
\text { castanho- } \\
\text { amarela } \\
\text { Monomorfa }\end{array}$ & & $\begin{array}{l}\frac{0}{0} \\
: \overline{0} \\
\frac{0}{\overline{0}} \\
\frac{0}{0} \\
0 \\
\frac{0}{0} \\
\frac{0}{0} \\
\frac{\overline{0}}{0}\end{array}$ & 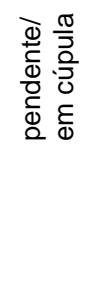 \\
\hline $\begin{array}{l}\text { T10/8 } \\
\text { Unidade II } \\
\text { AF } 2\end{array}$ & $\begin{array}{l}\text { Microagregados } \\
\text { intergranulares }\end{array}$ & $\begin{array}{l}\text { Vazio de } \\
\text { empacotamento } \\
\text { complexo }\end{array}$ & $\bullet \bullet \bullet$ & Aleatória & $50: 50$ & $\begin{array}{l}\text { Enáulica } \\
\text { fina/igual de } \\
\text { espaçamento } \\
\text { fechado/simples }\end{array}$ & $\bullet$ & $\bullet \bullet$ & & & • & $\bullet \bullet$ & • & $\begin{array}{l}\text { Indiferenciada } \\
\text { Amorfa, } \\
\text { castanho } \\
\text { escuro } \\
\text { Polimorfa }\end{array}$ & & & 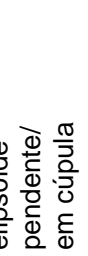 \\
\hline
\end{tabular}

Tab. 4. - Descrição micromorfológica das arqueofácies (AF) e subfácies (SF) identificadas na T10. Freqüências de classes segundo Bullock et al. (1985): • Muito Poucas (< $5 \%) ; \bullet$ Poucas $(5-15 \%) ; \bullet$ Comum $(15-30 \%) ; \bullet \bullet \bullet$ Freqüente $(30-50 \%) ; \bullet \bullet \bullet$ Dominante $(50-70 \%) ; \cdots \cdots \bullet$ Muito dominante $(>70 \%)$. 
Continuação Tabela 4. -

\begin{tabular}{|c|c|c|c|c|c|c|c|c|c|c|c|c|c|c|c|c|c|}
\hline \multirow[b]{2}{*}{ Lâmina } & \multirow[b]{2}{*}{ Microestrutura } & \multirow[b]{2}{*}{ Porosidade } & \multirow[b]{2}{*}{$\begin{array}{l}0 \\
\frac{0}{0} \\
\frac{0}{0}\end{array}$} & \multirow[b]{2}{*}{ Distribuição } & \multirow[b]{2}{*}{$\begin{array}{c}\text { Razão } \\
\text { c/f }\end{array}$} & \multirow[b]{2}{*}{$\begin{array}{l}\text { Padrão de } \\
\text { distribuição }\end{array}$} & \multicolumn{5}{|c|}{$\begin{array}{c}\text { Material } \\
\text { mineral } \\
\text { grosso } \\
\end{array}$} & \multicolumn{2}{|c|}{$\begin{array}{c}\text { Material } \\
\text { orgânico } \\
\text { grosso } \\
\end{array}$} & \multirow[b]{2}{*}{ Micromassa } & \multicolumn{3}{|c|}{$\begin{array}{c}\text { Feições } \\
\text { pedológicas }\end{array}$} \\
\hline & & & & & & & $\frac{8}{\frac{N}{0}}$ & $\begin{array}{l}\otimes \\
\frac{x}{0} \\
\frac{x}{0} \\
0 \\
0 \\
0 \\
0 \\
0 \\
0 \\
0\end{array}$ & 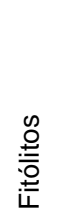 & 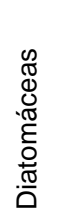 & 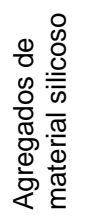 & 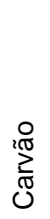 & 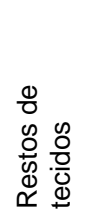 & & 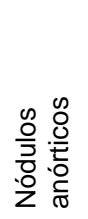 & 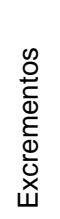 & 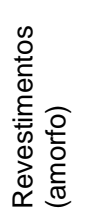 \\
\hline $\begin{array}{l}\text { T10/7 } \\
\text { Unidade V } \\
\text { SF } 3.1\end{array}$ & $\begin{array}{l}\text { Microagregados } \\
\text { intergranulares }\end{array}$ & $\begin{array}{l}\text { Vazio de } \\
\text { empacotamento } \\
\text { complexo }\end{array}$ & $\bullet \bullet$ & Aleatória & $60: 40$ & $\begin{array}{l}\text { Enáulica } \\
\text { fina/igual de } \\
\text { espaçamento } \\
\text { fechado/ simples }\end{array}$ & $\bullet \bullet$ & $\bullet \bullet$ & & & • & - & $\bullet \bullet$ & $\begin{array}{l}\text { Indiferenciada } \\
\text { Amorfa, } \\
\text { castanho- } \\
\text { amarela } \\
\text { Polimorfa }\end{array}$ & & $\begin{array}{l}\mathscr{0} \\
\frac{0}{0} \\
\frac{\pi}{\tilde{E}} \\
\stackrel{\widetilde{\sigma}}{\varepsilon} \\
\varepsilon\end{array}$ & 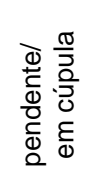 \\
\hline $\begin{array}{l}\text { T10/1 } \\
\text { Unidade VIB } \\
\text { SF } 3.3\end{array}$ & $\begin{array}{l}\text { Microagregados } \\
\text { intergranulares }\end{array}$ & $\begin{array}{l}\text { Vazio de } \\
\text { empacotamento } \\
\text { complexo }\end{array}$ & $\bullet \bullet \bullet$ & Aleatória & $40: 60$ & $\begin{array}{l}\text { Enáulica fina de } \\
\text { espaçamento } \\
\text { simples }\end{array}$ & $\bullet \bullet$ & $\bullet \bullet$ & $\bullet \bullet$ & $\bullet$ & & • & - & $\begin{array}{l}\text { Indiferenciada } \\
\text { Amorfa, } \\
\text { amarela } \\
\text { Polimorfa }\end{array}$ & & $\begin{array}{l}\stackrel{0}{0} \\
\frac{0}{0} \\
\frac{\pi}{\bar{E}} \\
\stackrel{\sigma}{\sigma} \\
\varepsilon\end{array}$ & 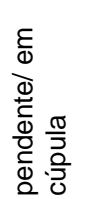 \\
\hline
\end{tabular}




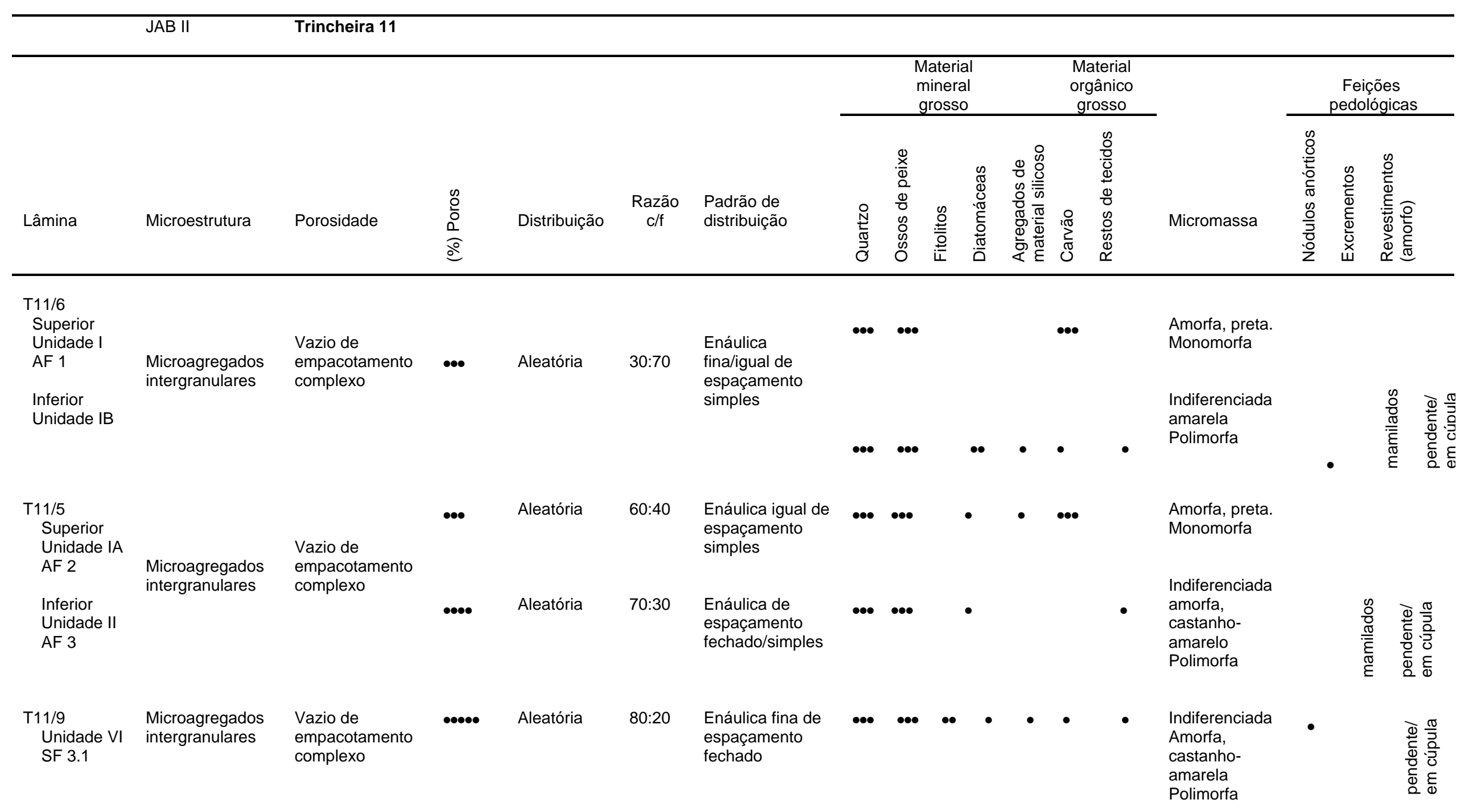

Tab. 5. - Descrição micromorfológica das arqueofácies (AF) e subfácies (SF) identificadas na T11. 
Continuação Tabela 5. -

\begin{tabular}{|c|c|c|c|c|c|c|c|c|c|c|c|c|c|c|c|c|c|}
\hline \multirow[b]{2}{*}{ Lâmina } & \multirow[b]{2}{*}{ Microestrutura } & \multirow[b]{2}{*}{ Porosidade } & \multirow[b]{2}{*}{$\begin{array}{l}0 \\
\frac{0}{0} \\
\frac{0}{0} \\
o\end{array}$} & \multirow[b]{2}{*}{ Distribuição } & \multirow[b]{2}{*}{$\begin{array}{l}\text { Razão } \\
\text { c/f }\end{array}$} & \multirow[b]{2}{*}{$\begin{array}{l}\text { Padrão de } \\
\text { distribuição }\end{array}$} & \multicolumn{4}{|c|}{$\begin{array}{c}\text { Material } \\
\text { mineral } \\
\text { grosso } \\
\end{array}$} & \multicolumn{3}{|c|}{$\begin{array}{c}\text { Material } \\
\text { orgânico } \\
\text { grosso } \\
\end{array}$} & \multicolumn{4}{|c|}{$\begin{array}{c}\text { Feições } \\
\text { pedológicas }\end{array}$} \\
\hline & & & & & & & $\begin{array}{l}\frac{0}{0} \\
\frac{0}{0} \\
\frac{0}{0} \\
0\end{array}$ & $\begin{array}{l}\ddot{\otimes} \\
\frac{x}{0} \\
\frac{0}{0} \\
0 \\
0 \\
0 \\
0 \\
0 \\
0 \\
0\end{array}$ & $\begin{array}{l}\stackrel{0}{\circ} \\
: \frac{0}{0} \\
: \frac{0}{4}\end{array}$ & 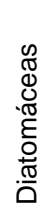 & 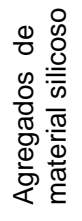 & $\sum_{0}^{2 \pi}$ & 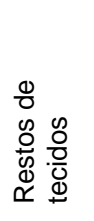 & Micromassa & 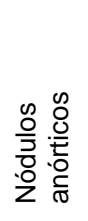 & 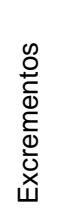 & 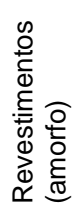 \\
\hline $\begin{array}{l}\text { T11/3 } \\
\text { Unidade VI } \\
\text { SF } 3.1\end{array}$ & $\begin{array}{l}\text { Microagregados } \\
\text { intergranulares }\end{array}$ & $\begin{array}{l}\text { Vazio de } \\
\text { empacotamento } \\
\text { complexo }\end{array}$ & $\bullet \bullet \bullet$ & Aleatória & $70: 30$ & $\begin{array}{l}\text { Enáulica } \\
\text { fina/igual de } \\
\text { espaçamento } \\
\text { simples }\end{array}$ & $\bullet \bullet$ & •••• & $\bullet$ & $\bullet$ & & - & • & $\begin{array}{l}\text { Indiferenciada } \\
\text { Amorfa, } \\
\text { castanho- } \\
\text { amarelo } \\
\text { Polimorfa }\end{array}$ & & $\begin{array}{l}\frac{0}{0} \\
\frac{\pi}{0} \\
\frac{\pi}{\bar{E}} \\
\stackrel{\widetilde{\sigma}}{\varepsilon}\end{array}$ & 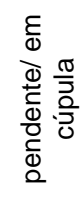 \\
\hline $\begin{array}{l}\text { T11/2 } \\
\text { Unidade X } \\
\text { SF } 3.1\end{array}$ & $\begin{array}{l}\text { Microagregados } \\
\text { intergranulares }\end{array}$ & $\begin{array}{l}\text { Vazio de } \\
\text { empacotamento } \\
\text { complexo }\end{array}$ & $\bullet \bullet$ & Aleatória & $70: 30$ & $\begin{array}{l}\text { Enálulica fina de } \\
\text { espaçamento } \\
\text { fechado/ } \\
\text { simples }\end{array}$ & $\bullet \bullet$ & $\bullet \bullet$ & $\bullet$ & & & $\bullet$ & $\bullet$ & $\begin{array}{l}\text { Indiferenciada } \\
\text { Amorfa, } \\
\text { castanho- } \\
\text { amarelo } \\
\text { Polimorfa }\end{array}$ & & 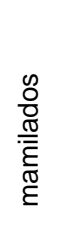 & 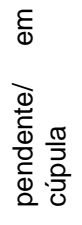 \\
\hline $\begin{array}{l}\text { T11/8 } \\
\text { Unidade XI } \\
\text { SF } 2.1\end{array}$ & $\begin{array}{l}\text { Com } \\
\text { microagregados } \\
\text { intergranulares }\end{array}$ & $\begin{array}{l}\text { Vazio de } \\
\text { empacotamento } \\
\text { complexo }\end{array}$ & $\bullet \bullet \bullet$ & Aleatória & $60: 40$ & $\begin{array}{l}\text { Enáulica fina de } \\
\text { espaçamento } \\
\text { fechado }\end{array}$ & $\bullet \bullet$ & $\bullet$ & & & $\bullet \bullet$ & $\bullet$ & $\bullet$ & $\begin{array}{l}\text { Indiferenciada } \\
\text { Amorfa, } \\
\text { castanho- } \\
\text { amarelo }\end{array}$ & & 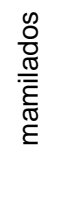 & 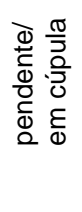 \\
\hline $\begin{array}{l}\text { Franja } \\
\text { Central }\end{array}$ & Laminar & Planar & $\bullet$ & Listrada & $40: 60$ & $\begin{array}{l}\text { Porfirica de } \\
\text { espaçamento } \\
\text { simples }\end{array}$ & $\bullet \bullet$ & $\bullet \bullet$ & & $\bullet$ & $\bullet$ & • & & Polimorfa & & & \\
\hline
\end{tabular}


Continuação Tabela 5. -

\begin{tabular}{|c|c|c|c|c|c|c|c|c|c|c|c|c|c|c|c|c|c|}
\hline \multirow[b]{2}{*}{ Lâmina } & \multirow[b]{2}{*}{ Microestrutura } & \multirow[b]{2}{*}{ Porosidade } & \multirow[b]{2}{*}{$\begin{array}{l}0 \\
\frac{0}{0} \\
\frac{0}{a}\end{array}$} & \multirow[b]{2}{*}{ Distribuição } & \multirow[b]{2}{*}{$\begin{array}{c}\text { Razão } \\
\text { c/f }\end{array}$} & \multirow[b]{2}{*}{$\begin{array}{l}\text { Padrão de } \\
\text { distribuição }\end{array}$} & \multicolumn{4}{|c|}{$\begin{array}{c}\text { Material } \\
\text { mineral } \\
\text { grosso } \\
\end{array}$} & \multicolumn{3}{|c|}{$\begin{array}{c}\text { Material } \\
\text { orgânico } \\
\text { grosso } \\
\end{array}$} & \multicolumn{4}{|c|}{$\begin{array}{l}\text { Feições } \\
\text { pedológicas }\end{array}$} \\
\hline & & & & & & & $\frac{\stackrel{2}{1}}{\frac{0}{0}}$ & 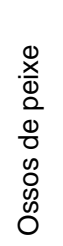 & 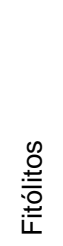 & 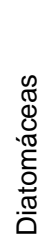 & 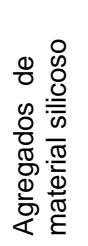 & $\sum_{\substack{0 \\
0}}^{20}$ & 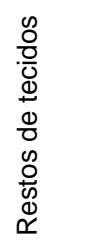 & Micromassa & 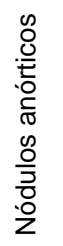 & 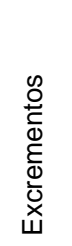 & 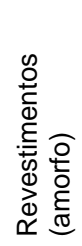 \\
\hline $\begin{array}{l}\text { T11/1 } \\
\text { Unidade XII } \\
\text { SF } 3.1\end{array}$ & $\begin{array}{l}\text { Microagregados } \\
\text { intergranulares }\end{array}$ & $\begin{array}{l}\text { Vazio de } \\
\text { empacotamento } \\
\text { complexo }\end{array}$ & ••.• & Aleatória & $70: 30$ & $\begin{array}{l}\text { Enáulica fina de } \\
\text { espaçamento } \\
\text { simples }\end{array}$ & $\bullet \bullet$ & $\bullet \bullet$ & $\bullet$ & & • & • & • & $\begin{array}{l}\text { Indiferenciada } \\
\text { Amorfa, } \\
\text { castanho- } \\
\text { amarelo } \\
\text { Polimorfa }\end{array}$ & & & 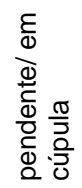 \\
\hline $\begin{array}{l}\text { T11/7 } \\
\text { Unidade XIV } \\
\text { AF } 5\end{array}$ & $\begin{array}{l}\text { Microagregados } \\
\text { intergranulares }\end{array}$ & $\begin{array}{l}\text { Vazio de } \\
\text { empacotamento } \\
\text { complexo }\end{array}$ & •..• & Aleatória & $60: 40$ & $\begin{array}{l}\text { Enáulica grossa/ } \\
\text { Igual de } \\
\text { espaçamento } \\
\text { fechado/simples }\end{array}$ & $\bullet \bullet$ & $\bullet \bullet$ & & • & • & • & & $\begin{array}{l}\text { 1. Indiferenc. } \\
\text { laranja- } \\
\text { amarela } \\
\text { Polimorfa } \\
\text { 2. Amorfa, } \\
\text { preta } \\
\text { Monomorfa }\end{array}$ & & & 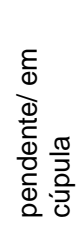 \\
\hline
\end{tabular}


O estudo micromorfológico das arqueofácies identificadas nas trincheiras 10 e 11 permitiu reconhecer uma série de elementos comuns à totalidade das lâminas analisadas. Estes elementos estão vinculados à trama e à composição das arqueofácies identificadas (fração grossa e micromassa) e podem se agrupar da seguinte maneira:

- Microestrutura composta por microagregados intergranulares

- Porosidade de tipos vazio de empacotamento complexo e distribuição aleatória

- Padrão de distribuição da massa basal (fração grossa e micromassa) de tipo enáulico

- Composição e morfologia da fração grossa variável em função da proporção relativa entre os diferentes componentes:
1) Fragmentos de
2) Grãos de quartzo
3) Carvão

ossos de peixe

Mal selecionados. Bem selecionados. Mal selecionados.

Distribuição aleatória. Distribuição aleatória. Distribuição aleatória.

Angulares- Muito arredondados, Subangulares, toscos.

subangulares, suaves.

ondulados.

- Micromassa composta por material orgânico amorfo, monomórfico e preto, misturada com micromassa indiferenciada (criptocristalina) castanhoamarelo e laranja.

\subsection{1. - Padrão de distribuição}

Embora a maior parte das lâminas analisadas apresentasse um padrão de distribuição enáulico (fração grossa e agregados de material fino nos espaços intersticiais), em algumas lâminas observaram-se também padrões de distribuição de tipo gefúrico convexo (fração grossa ligada por pontes de material fino) e mônico grosso (fração grossa e poros, sem micromassa). Padrões gefúricos convexos podem ser observados sempre em alguma porção da quase totalidade das lâminas analisadas. Padrões mônicos grossos foram observados na unidade VI da T11, subfácies 3.1, na unidade XII T11, subfácies 3.1 e na unidade VIB da T10, subfácies 3.3. 


\subsection{2. - Fração grossa}

A composição da fração grossa permanece constante ao longo da vertical nas seções estudadas. O marcado predomínio dos restos arqueofaunísticos é acompanhado por grãos de quartzo e carvão. A grande diferença observada refere-se à quantidade relativa de carvão. Em termos gerais, aquelas arqueofácies e subfácies identificadas como ricas em materiais queimados (arqueofácies 2 e subfácies 2.1) apresentam maiores quantidades de carvão na sua composição, embora alguns carvões também fossem observados nas demais arqueofácies identificadas.
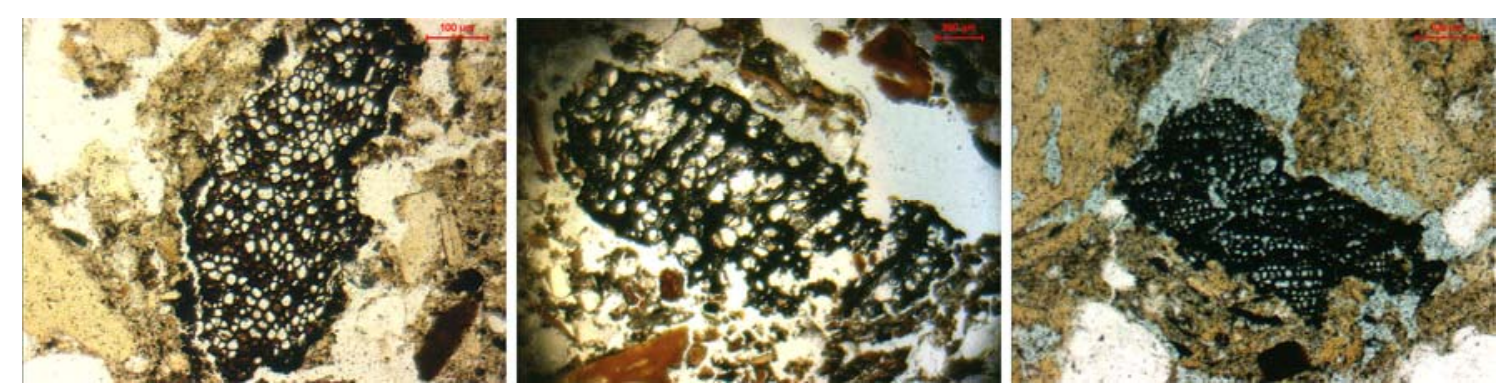

Fig. 30. - Fragmentos de carvão nas arqueofácies 1 (esquerda) e subácies 3.1 (centro e direita). Fotomicrografias tomadas no microscópio óptico de luz polarizada com nicóis paralelos (PPL).

Ossos e carvões apresentam má seleção granulométrica e morfométrica (critérios baseados em Bullock et al. 1985), indicada pela ampla variedade de tamanhos e formas observada ao longo de todas as arqueofácies. Da mesma maneira, suas bordas são sempre angulares e toscas, o que também indica pouco ou nenhum transporte físico por agentes naturais. A presença conjunta destes elementos num depósito está geralmente associada à influência antrópica e, portanto, a processos de transporte antrópico responsáveis pela sua deposição no local. Nos grãos de quartzo a situação é diferente. Sua boa seleção, alta esfericidade e arredondamento indicam processos de transporte naturais que podem estar vinculados, pela evidência apresentada no tópico 5.2.3, a depósitos paleolagunares. Porém, sua presença na camada preta conjuntamente com ossos e carvões transportados antropicamente em micromassa polimorfa organo-mineral não é característica de nenhum processo natural conhecido; portanto, seu transporte último também teria sido de tipo antrópico. 


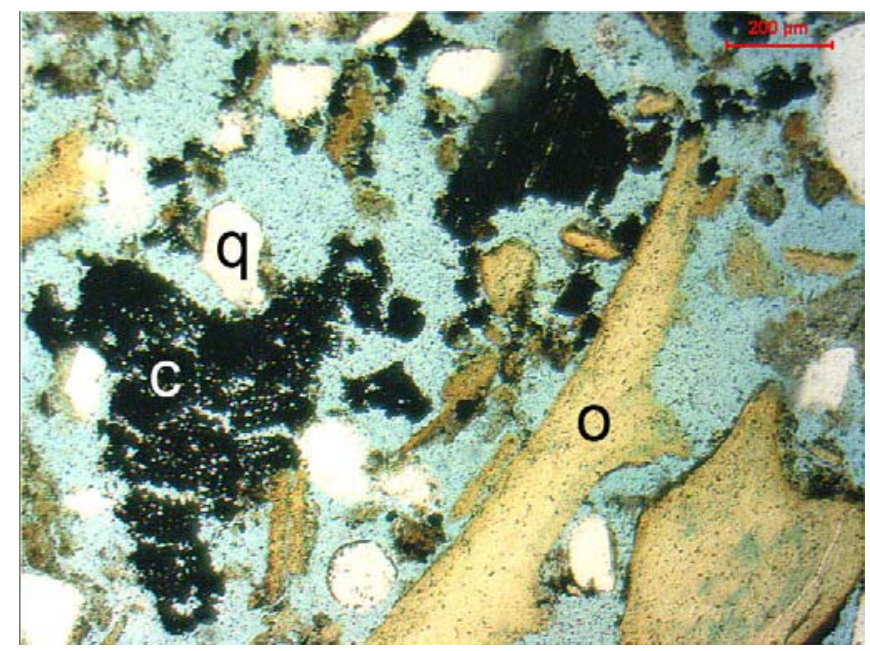

Fig. 31. - Massa basal composta por grãos de quartzo (q) bem arredondados e selecionados e fragmentos de osso (o) e carvão (c) de tamanho variado. T11, unidade VI, subfácies 3.1. Fotomicrografia em PPL.

Portanto:

A evidência apresentada pela fração grossa indica que em todas as arqueofácies estudadas existe uma mistura de componentes naturais, representados pelos grãos de quartzo, com componentes vinculados à atividade antrópica, representados pelos ossos carvões. Sua presença conjunta e misturada no depósito reforça a hipótese de natureza antrópica para a camada preta, em termos de transporte e deposição de materiais constituintes.

Microscopicamente os restos arqueofaunísticos apresentaram-se altamente fragmentados. Esta fragmentação pode estar relacionada à queima ou ao intemperismo sofridos por estes materiais. O tecido ósseo, no animal ainda vivo, é muito resistente; porém, os ossos são enfraquecidos tanto na diagênese como na queima (de maneira instantânea). Principalmente após o ato da queima, a capacidade do osso de resistir à quebra diminui consideravelmente e o osso fica frágil e altamente fragmentável e desmanchável (Steiner et al. 1995: 229).

Porém, não é a queima em si mesma o que fragmenta os ossos, mas qualquer pressão posteriormente exercida sobre seu material já enfraquecido por esta queima. $O$ pisoteio, por exemplo, provocado pela visita recorrente de populações humanas ao mesmo local, é uma das causas principais de fragmentação em contextos culturais (Steiner et al. 1995: 235). Esta ação poderia ser uma das responsáveis pela alta fragmentação dos restos arqueofaunísticos da camada preta, já que, desde o começo da sua construção até o momento de abandono do sítio, passaram-se cerca de 500 anos. 
Durante esse intervalo de tempo, o local foi freqüentemente visitado pelas populações sambaquieiras. Esta suposição não exclui a possibilidade de a alta fragmentação deverse a outros fatores, como o transporte antrópico, por exemplo, já que a fração grossa das arqueofácies que compõem a camada preta dão evidências de que a deposição destes materiais envolveu a coleta e o transporte por agentes humanos.

Deste modo:

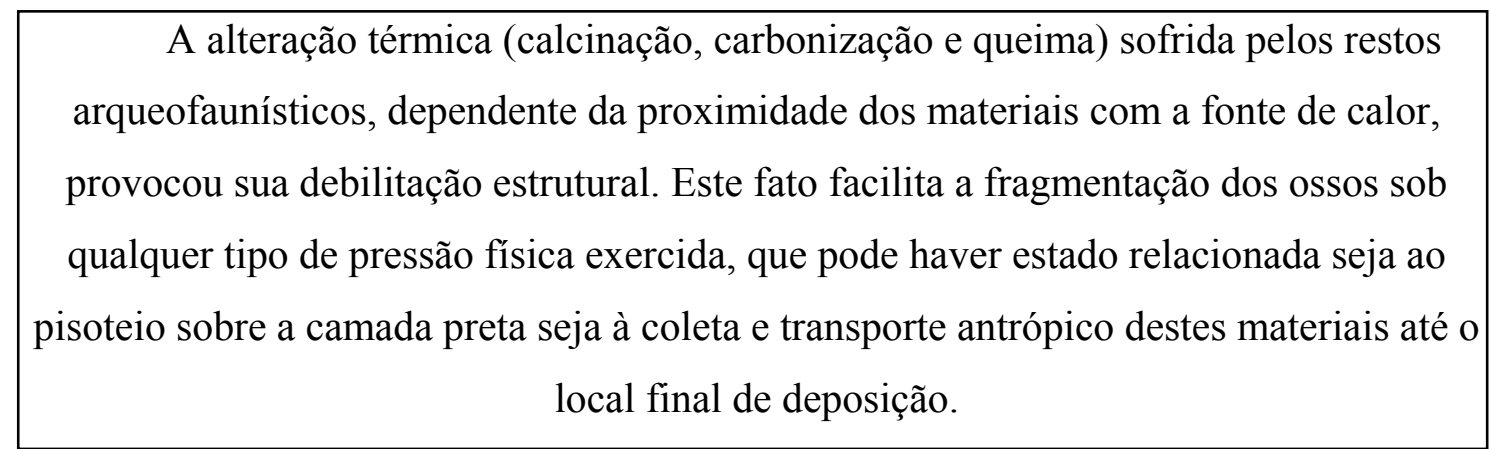

Além dos fragmentos ósseos, foram também identificados na fração grossa da camada preta outros resíduos inorgânicos de origem biológica, como fitólitos e diatomáceas. Compostos de opala (sílica coloidal hidratada, de baixa cristalinidade, portanto opticamente isótropa), os fitólitos formam-se normalmente dentro de ou entre as células vegetais, particularmente nos órgãos aéreos das plantas, nos quais a evaporação é maior. Suas dimensões variam aproximadamente de 10 a $50 \mu \mathrm{m}$, em média. As gramíneas são as espécies que mais fitólitos produzem, porém os fitólitos, como os grãos de pólen, não apresentam formas características de um táxon, espécie ou gênero. Cada táxon produz múltiplas formas e formas idênticas são comuns a vários táxons diferentes (Courty et al. 1989; Brochier 2002).

As diatomáceas são algas unicelulares que possuem esqueleto externo de opala, podem apresentar simetria radial ou bilateral e assumir diferentes formas. Estes organismos podem ocorrer tanto em corpos de água como em depósitos sedimentares (Stoops 2003: 75). 

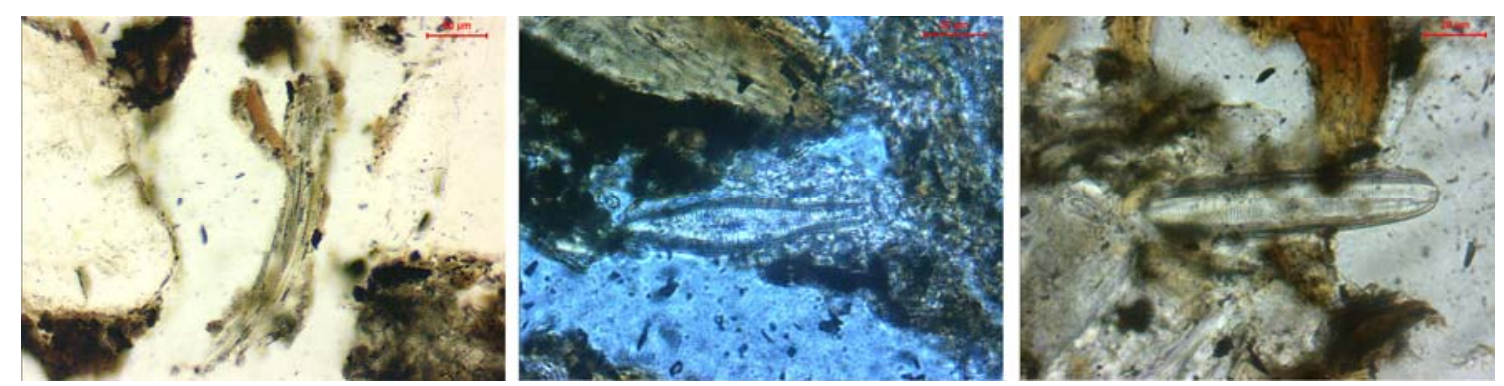

Fig. 32. - Fitólitos (esquerda) e diatomáceas (centro e direita) na camada preta. Fotomicrografias em PPL.

Quanto à presença de diatomáceas na camada preta, destaca-se a metade inferior da unidade VIB (subfácies 3.3) na T10, que apresenta elevada concentração de fragmentos de osso com tamanho consideravelmente maior que o observado no restante das lâminas. Essa amostra apresenta alta concentração de frústulas de diatomáceas aleatoriamente dispostas entre os ossos (fig. 33).
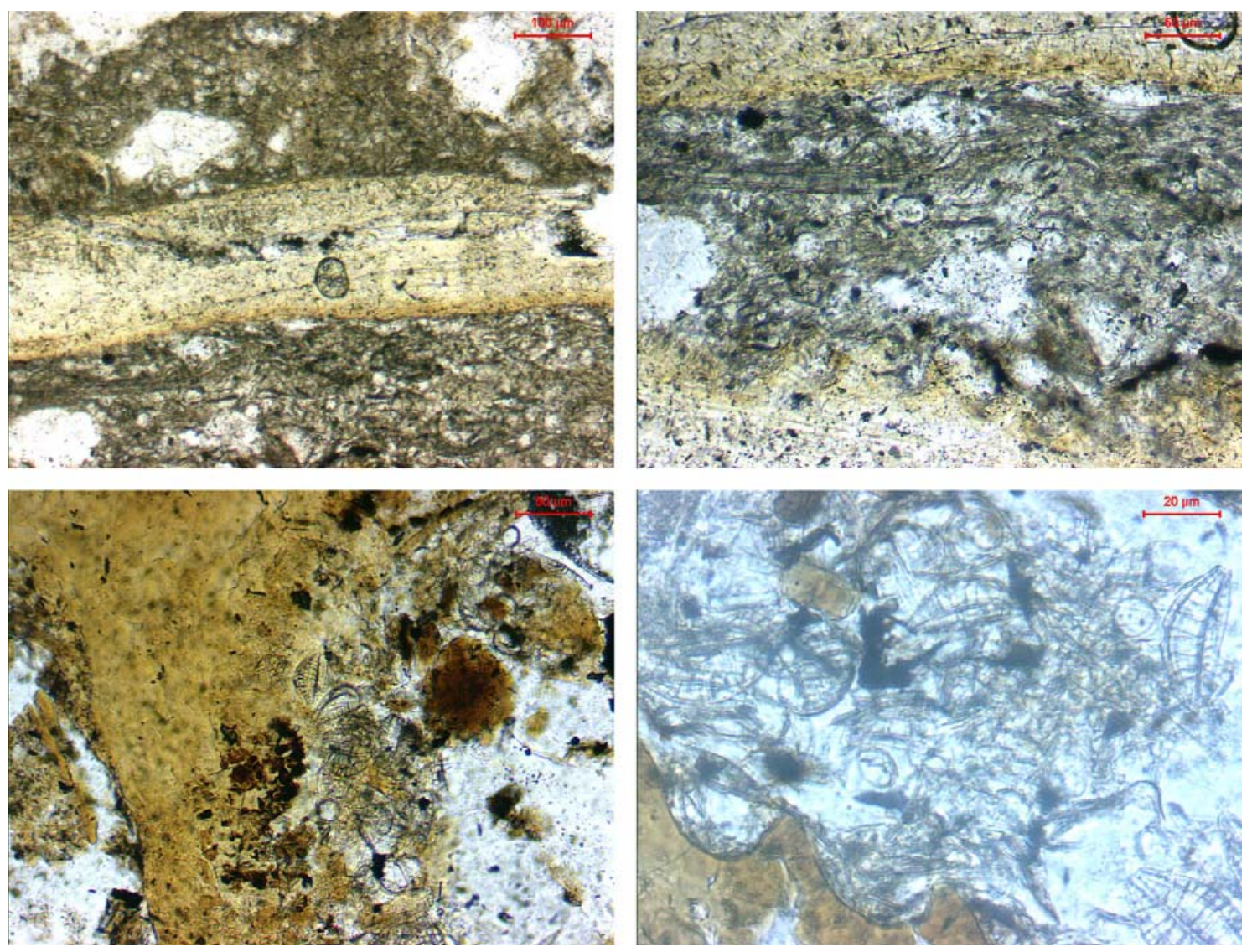

Fig. 33. - Concentração de frústulas de diatomáceas entre restos arqueofaunísticos na arqueofácies 3.3, T10. Fotomicrografias em PPL. 
Um componente particular que chama a atenção na fração grossa da camada preta são os denominados agregados de material silicoso. Estes agregados são incolores sob luz plano-polarizada e apresentam-se isótropos sob polarizadores cruzados. Tal comportamento óptico é típico da sílica amorfa, como se viu na descrição dos fitólitos e diatomáceas. Porém, estes materiais não apresentam morfologia que permita associá-los a microfósseis ou outros tipos de grãos conhecidos (fig. 34).
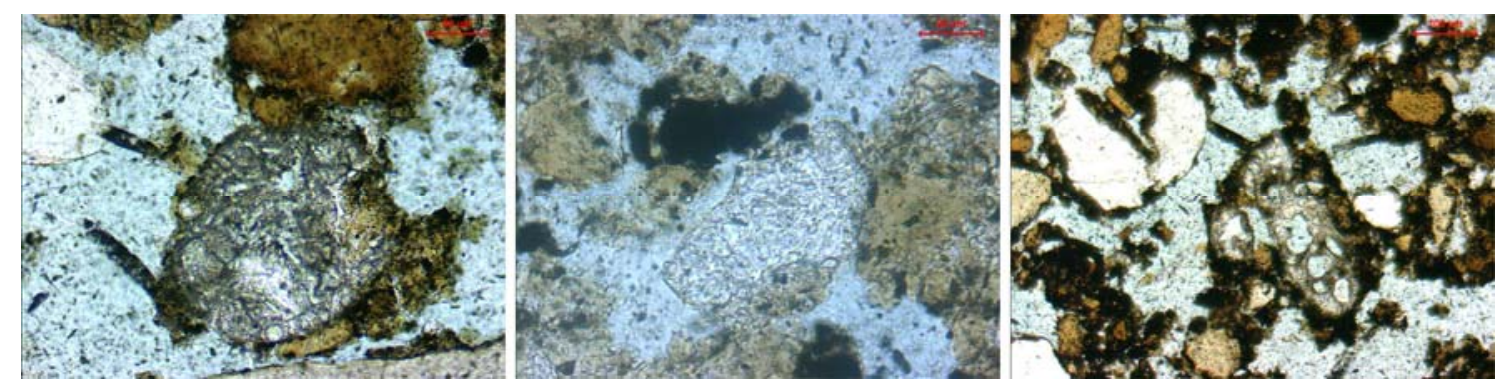

Fig. 34. - Agregados de material silicoso na T10, subfácies 3.1, unidade V (esquerda e centro) e arqueofácies 2, unidade II (direita).

Pela sua textura interna e composição de sílica amorfa, sua origem pode estar relacionada pelo menos a três componentes do registro: os grãos de quartzo, os fitólitos ou as diatomáceas. Existem diversas evidências da presença, na camada preta, de materiais termicamente alterados (carbonizados, calcinados etc.). O quartzo pode sofrer igualmente os efeitos das altas temperaturas e transformar-se num de seus polimorfos (opala-A, opala-C, opala-T, cristobalita) inclusive abaixo do ponto de fusão do seu estado puro caso coexista no depósito com materiais alcalinos, como podem ser os ossos. A temperaturas normais em fogueiras antrópicas $\left(400-600^{\circ} \mathrm{C}\right)$, o quartzo permanece inalterado, mas acima dos $800^{\circ} \mathrm{C}$ sua alteração pode começar e entre $1000 \mathrm{e}$ $1200^{\circ} \mathrm{C}$, pode já se transformar em opala (Courty et al. 1989; Berna et al. 2007). Portanto, uma possibilidade para a gênese dos materiais silicosos é a alteração dos grãos de quartzo produzida pelas altas temperaturas alcançadas nas fogueiras antrópicas.

Situação semelhante pode ter acontecido com os fitólitos e diatomáceas. Estes materiais, também compostos de sílica amorfa, podem começar a se derreter a partir dos $800^{\circ} \mathrm{C}$, se coexistirem no depósito com ossos. Estas temperaturas podem derreter concentrações de fitólitos ou diatomáceas e originar assim agregados semelhantes aos materiais silicosos identificados na camada preta. 


\subsection{3. - Micromassa}

Todas as arqueofácies e subfácies identificadas nos perfis das trincheiras 10 e 11 estão constituídas por uma micromassa amorfa misturada com uma micromassa indiferenciada (criptocristalina) de baixa birrefringência na forma de uma micromassa polimorfa organo-mineral. Nas arqueofácies 3, subfácies 3.1 e 3.3, esta micromassa é majoritariamente castanho-amarela, indiferenciada, com manchas preta, amorfas. No caso das arqueofácies 1 e 2, a micromassa é majoritariamente amorfa, monomorfa e preta. Já na subfácies 2.1 e na unidade IB da T11, que corresponde a uma mancha cinza dentro da unidade I (arqueofácies 1), a micromassa é indiferenciada e apresenta cor cinza amarelado. As características desta micromassa serão discutidas mais adiante.

As diferenças observadas na constituição da micromassa são elementos chave na caracterização das arqueofácies e subfácies, já que a composição da fração grossa permanece a mesma ao longo dos perfis. A micromassa polimorfa castanho-amarela parece ser de natureza fosfática e ocorre misturada com microcarvões e fitólitos; enquanto isso a micromassa monomorfa preta estaria predominantemente composta por carvões e microcarvões.

$\mathrm{Na}$ diagênse, a fase cristalina que compõe o carvão tende a degradar-se via oxidação e a converter-se em material semelhante às substancias húmicas (Cohen-Ofri et al. 2006). Dada a baixa porcentagem de MO na camada preta, as partículas pretas e amorfas que se observam microscopicamente não estariam associadas aos produtos da alteração intempérica dos carvões, componente significativo destes sedimentos arqueológicos. A composição das micromassa estaria relacionada com a presença relativa de restos carbonizados de plantas e ossos, misturados provavelmente com a fosfomicrita (fosfato criptocristalino) produzida pela dissolução e reprecipitação da hidroxiapatita (ver tópico 5.3.3).

Reprecipitada quimicamente como material pós-deposicional autígeno, a fosfomicrita apresentar-se-ia na forma de micromassa e como feição pedológica nitidamente separada do material parental (Bullock et al. 1985: 118). Esta fosfomicrita pode ter sido tanto transportada como formada in situ, embora pela evidência apresentada pelas concreções (Mazini 2007) a segunda opção pareça a mais provável. 

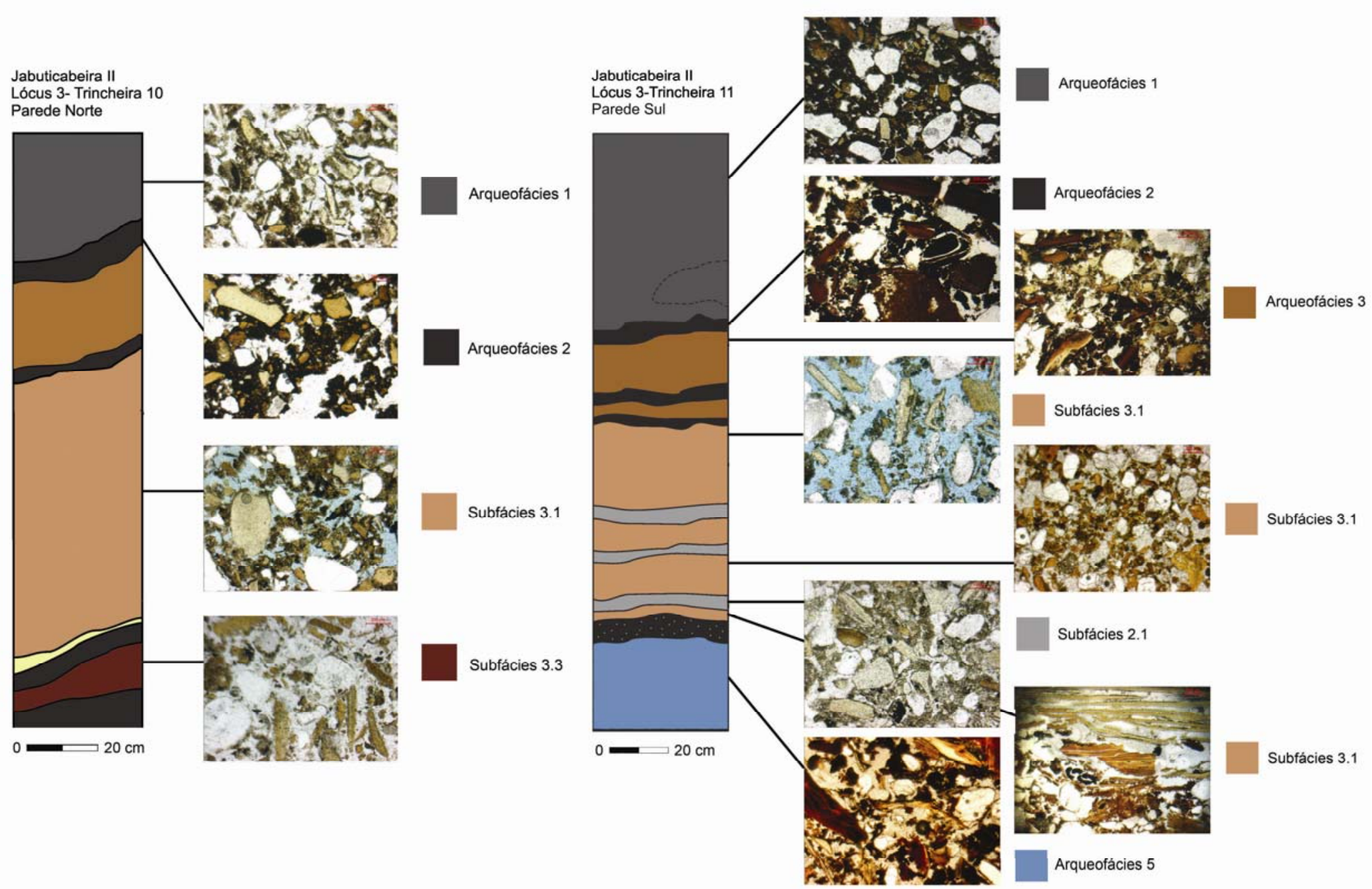

Fig. 35. - Seções estratigráficas da T10 e T11 com a localização das arqueofácies e subfácies reconhecidas macroscopicamente e as microarqueofácies e microsubfácies correspondentes. Fotomicrografias em PPL. 
Portanto:

A micromassa da camada preta representa uma mistura de material orgânico, representado pelos carvões e microcarvões, e inorgânico, representado pela fosfomicrita. O material inorgânico tem a particularidade de haver sido produzido na diagênese.

\subsection{4. - Atividade biológica}

A microestrutura predominante em todas as arqueofácies e subfácies é de agregados intergranulares. Este tipo de microestruturas é freqüente em horizontes A de solos naturais (Simpson \& Barret 1996), que apresentam alto conteúdo orgânico e forte atividade biológica. A endofauna do solo tem papel fundamental na redistribuição dos componentes orgânicos e minerais, através da formação de galerias da produção de excrementos (Babel 1975; Stein 1983). A ação biológica, junto com a percolação da água, mais intensa nos horizontes superficiais, são os principais responsáveis pela configuração de microestruturas como as observadas na camada escura.

Cabe ressaltar que os sedimentos arqueológicos, em geral, são particularmente ricos em termos de atividade biológica relacionada à fauna do solo e às plantas colonizando o substrato. A ação conjunta destes agentes produz uma combinação de modificações físicas (homogeneização mecânica) e bioquímicas (decomposição e degradação da MO) que pode chegar a alterar completamente as características originais do depósito arqueológico com a passagem do tempo (Courty et al. 1989). Este poderia ser o caso da camada preta, cuja microestrutura atual pode ser conseqüência de anos de percolação da água e ação da fauna do solo no seu interior, e não refletiria, portanto, o arranjo original destes sedimentos no momento da sua deposição.

A ação da fauna do solo não é unicamente identificada pelo arranjo microestrutural. Os excrementos produzidos por estes organismos constituem feição pedológica importante para confirmar atividade animal antiga ou atual no depósito. Em função das características composicionais do solo ou sedimento os organismos que nele habitam produzirão excrementos que poderão ser fundamentalmente orgânicos, minerais ou organominerais (Babel 1975; Bullock et al. 1985; Courty et al. 1989). 
No caso da camada preta, em várias arqueofácies identificaram-se possíveis excrementos e restos de excrementos produzidos pela fauna do solo. Estes apresentaram-se majoritariamente na forma de macroexcrementos (dimensão milimétrica) formados por agregados densos elipsoidais ou mamilados. Sua composição é essencialmente a mesma do depósito, ou seja, fragmentos de osso, fitólitos e grãos de quartzo dentro de uma micromassa orgânica e amorfa misturada com uma micromassa indiferenciada de baixa birrefringência. Não obstante, estes agregados poderiam também representar peloides delimitados por galerias de bioturação.

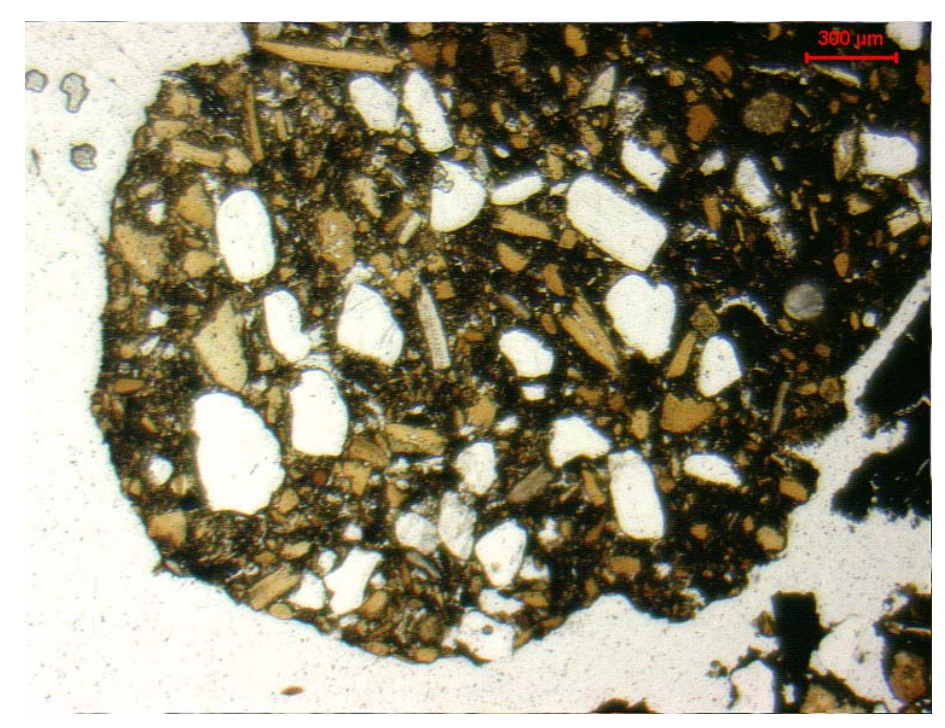

Fig. 36. - Imagem de um possível excremento ou peloide localizado dentro de um canal. T10, arqueofácies 1. Fotomicrografia em PPL.

Este tipo de alteração biológica pode ser também modificada por processos pedológicos subseqüentes, da mesma natureza ou não. Os excrementos ou peloides sofrem um envelhecimento devido ao processo de alteração que resulta na perda da sua forma original (Bullock et al. 1985). Estes podem se desintegrar pela percolação de água no sistema ou podem ser ingeridos por outros organismos, sendo re-excretados com formas diferentes.

As raízes da vegetação que se estabelece no solo ou sedimento altera o arranjo dos materiais que os compõem, e assim produzem modificações mecânicas semelhantes às ocasionadas pela fauna. Porém, a ação das raízes é mais lenta que as dos animais (seu impacto cresce conforme aumenta o diâmetro da raiz) e sua ação nem sempre é facilmente distinguível da criada por aqueles. A ação das plantas e dos organismos não se restringe à alteração física do solo. Reações químicas e físico-químicas também são induzidas pelas substâncias orgânicas produzidas pelas raízes e a atividade bacteriana 
associada, que resultam na alteração de certos minerais e na criação de novos complexos organo-minerais (Babel 1975; Courty et al. 1989).

$\mathrm{Na}$ camada preta, a presença de raízes foi observada macroscopicamente ao longo dos dois perfis estudados, com diminuição em quantidade e diâmetro da superfície para a base.
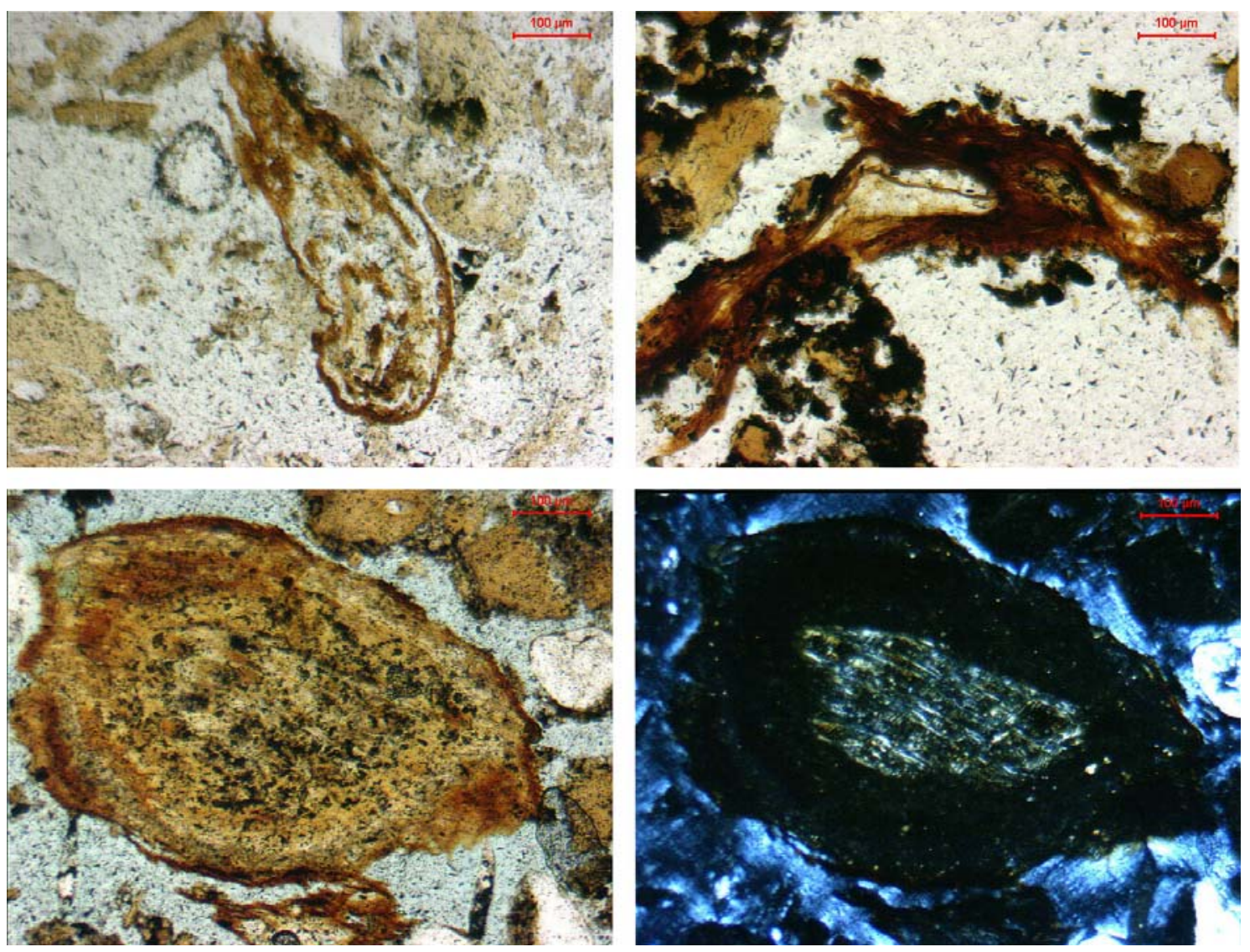

Fig. 37. - Evidências de atividade biológica na camada preta. As duas fotomicrografias superiores correspondem a substâncias orgânicas recentes. As fotomicrografias inferiores referem-se a seção transversal de raiz em PPL (esquerda) e nicóis cruzados (XPL) (direita). As cores de interferência no interior da raiz correspondem às paredes das células, ricas em celulose (Babel 1975; Bullock et al. 1985).

As substâncias orgânicas caracterizam-se por não apresentar estruturas microscopicamente definitivas e reconhecíveis. Formam-se pela desintegração de resíduos de plantas ou pela precipitação de solutos orgânicos ou aglutinação de colóides (ver fig 38). À diferença das substâncias orgânicas, os restos de plantas são partes coerentes de tecidos reconhecíveis ao microscópio (Babel 1975: 377). Substâncias orgânicas foram também identificadas na camada preta, particularmente aquelas correspondentes a restos de tecidos vegetais, definidos como tal por apresentar mais de cinco células interconectadas (ver fig 37). 

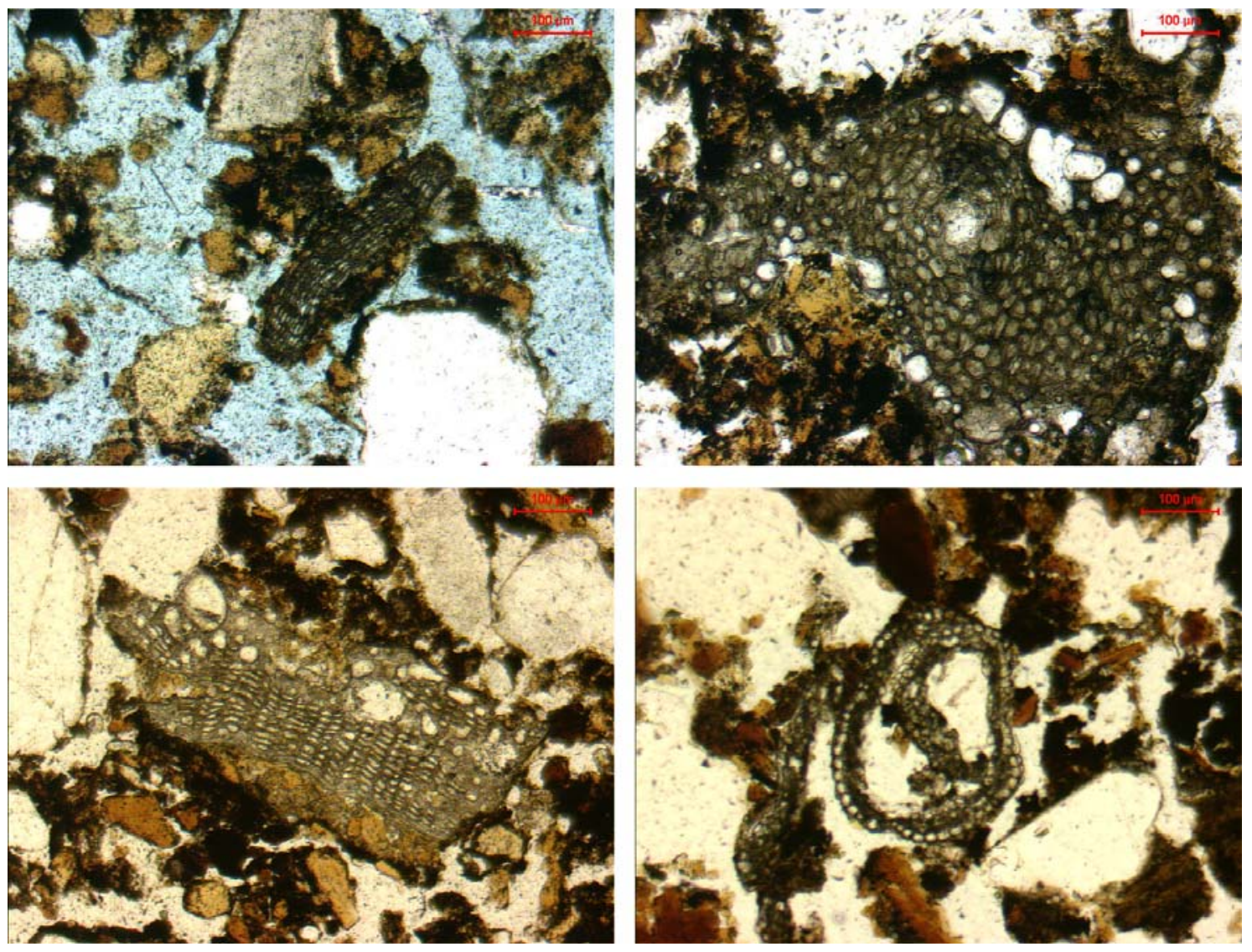

Fig. 38. - Restos de tecidos vegetais na camada preta. Superior esquerda: fragmento de epiderme, provavelmente proveniente do talo (T10, unidade V, subfacies 3.1). Superior direita: fragmento de tecido indiferenciado (T10, unidade I, arqueofácies I). Inferior esquerda: resto de epiderme, mesofilo e cutícula (T11, unidade VI, subfácies 3.1). Inferior direita: células enroladas, provavelmente de epiderme de folha (T11, unidade XII, subfácies 3.1).

\subsection{5. - Feições pedológicas}

Em todas as arqueofácies e subfácies estudadas, foram identificados os denominados encobrimentos (coatings). Trata-se de feições pedológicas que recobrem uma superfície natural (poros, grãos ou agregados) presente no solo. Resultam do transporte em suspensão de materiais finos, embora não exclusivamente (Stoops 2003). Estes encobrimentos podem ser cristalinos, criptocristalinos ou amorfos, formados in situ ou infiltrados.

$\mathrm{Na}$ camada preta, estes encobrimentos envolvem os grãos de quartzo, os fragmentos ósseos e até os agregados de material silicoso total ou parcialmente. Apresentam-se pendentes ou em cúpula e em dois hábitos diferentes: como material castanho indiferenciado (criptocristalino), amorfo e mal selecionado, composto por 
materiais na fração silte (fragmentos ósseos) até argila sem laminação; e como material indiferenciado, amorfo, de coloração laranja, límpido ou impuro, também sem laminação.

Em termos gerais, estes encobrimentos apresentam composição semelhante à da micromassa. A percolação da água no depósito provoca o a lixiviação dos materiais finos e a dissolução de componentes orgânicos (colágeno, restos paleobotânicos) e inorgânicos (restos arqueofaunísticos) em função das condições de $\mathrm{pH}$ e Eh do sedimento em questão, como se discutiu no tópico 5.4. Os materiais finos, junto com aqueles dissolvidos, são transportados pela água ao longo do perfil e acabam se depositando como encobrimentos que envolvem os materiais da fração grossa.

Aqueles encobrimentos organo-minerais e mal selecionados, poderiam estar relacionados com este processo. Já aquele recobrimento laranja e indiferenciado, poderia se tratar de uma neoformação presumivelmente fosfática, como tem se discutido no tópico 5.4. Recobrimentos criptocristalinos podem resultar tanto da exposição superficial ao intemperismo como dos processos de dissolução e reprecipitação que acontecem na profundidade dos perfis. Por isso, esta feição deve ser tomada como indicador ambíguo de pedogênese e deve ser interpretada com cautela.
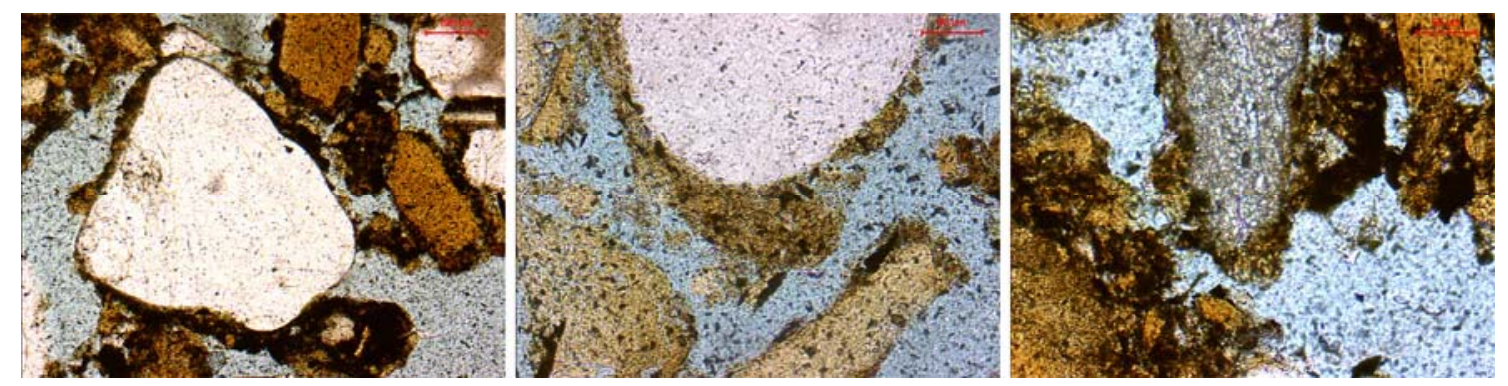

Fig. 39. - Encobrimentos em cúpula e pendulares na subfácies 3.1. da T10 (unidade V) (esquerda) e na T11 (unidade VI), respectivamente. Encobrimento pendular em agregado de material silicoso da subfácies 3.1 na $\mathrm{T} 10$ (unidade $\mathrm{V}$ ).

O segundo tipo de feição pedológica identificada em ambas as trincheiras foram os denominados nódulos. Os nódulos são feições pedológicas relativamente equidimensionais não relacionadas a poros ou superfícies naturais (grãos ou agregados) (Bullock et al. 1985; Stoops 2003). Não obstante, determinar se um nódulo é efetivamente pedogênico ou se se trata de um elemento herdado nem sempre é fácil. Caso pedogênico, seria feição pedológica, mas se herdado seria componente da massa basal. Como esta identificação é ambígua, decidiu-se incluir todos os tipos de nódulos observados sob a categoria de feições pedológicas (ver tabelas 4 e 5). 
Os corpos nodulares herdados do material parental ou formados pedogenicamente em sedimentos derivados de um solo que sofreu processos de transporte, denominam-se nódulos anórticos. Caracterizam-se pelos limites abruptos e pela massa basal interna diferenciada, em termos de natureza e arranjo, à do solo ou sedimento no qual se encontram (Stoops 2003: 117). Este tipo de nódulo foi observado recorrentemente na camada preta. Sua origem está provavelmente vinculada ao transporte mecânico, por agentes antrópicos, desde o local original da sua formação.
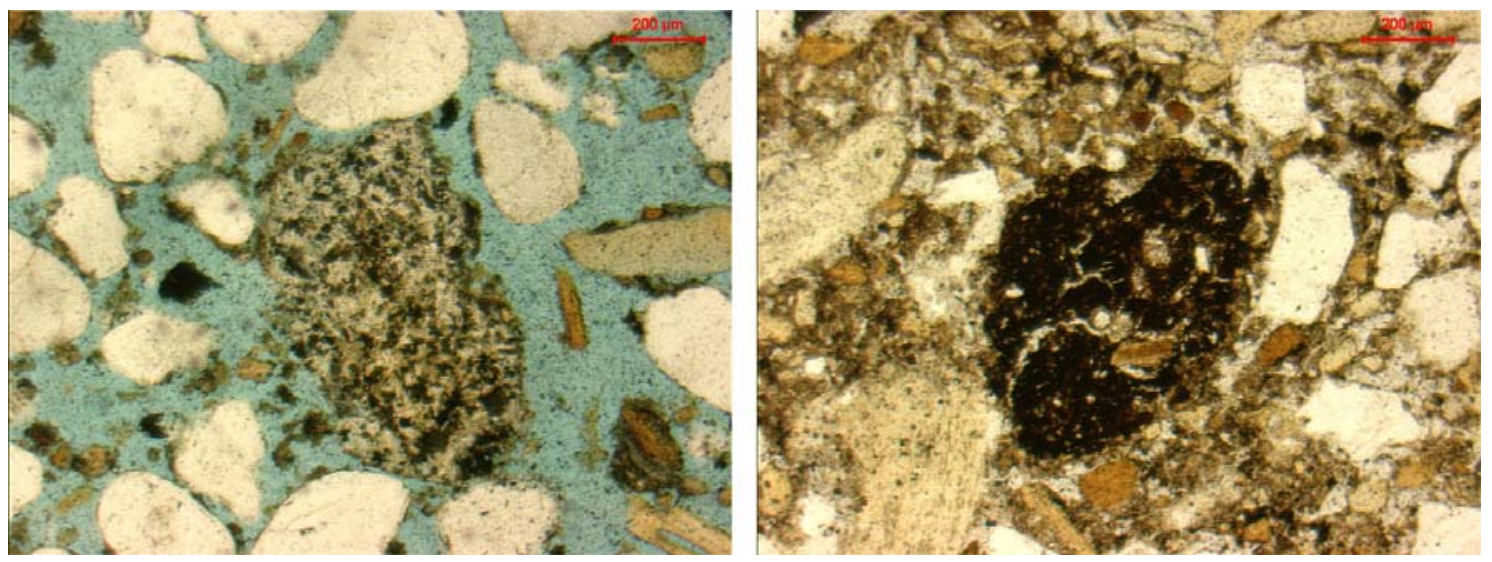

Fig. 40. - Dois exemplos de nódulos anórticos encontrados nas unidades VI e I da T11 (subfácies 3.1 e arqueofácies 1, respectivamente). Fotomicrografias em PPL.

$\mathrm{Na}$ figura 40, apresentam-se dois exemplos diferentes de nódulos anórticos na camada preta. A fotomicrografia da direita corresponde a um nódulo anórtico de composição orgânica, provavelmente produzido por processos pedológicos em outro local e transportado posteriormente até a camada escura. $\mathrm{Na}$ fotomicrografia da esquerda, a situação é diferente. Este nódulo é composto de fitólitos alongados, microcarvões e material orgânico fino, marrom claro e polimorfo (ver fig. 41). Pela sua composição este nódulo parece ter sido formado na camada preta e ter sofrido deslocamento do seu entorno sedimentar original. Este tipo de situação corresponderia então com os denominados nódulos disórticos, que se caracterizam por ter limites abruptos e por terem sido formados in situ, mas deslocados internamente no sedimento. Porém, os nódulos disórticos freqüentemente são deslocados dentro do horizonte da sua formação, e neste caso não se pode determinar com absoluta certeza se o nódulo provém da unidade VI na qual se encontra ou se veio de uma outra localidade dentro do perfil. 


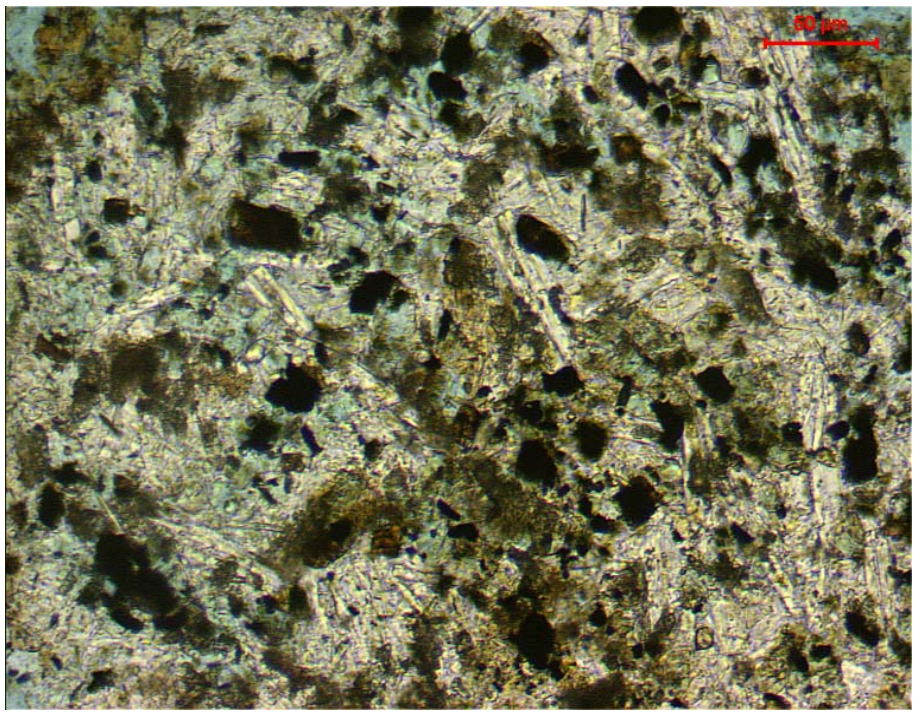

Fig. 41. - Detalhe da composição interna do nódulo anórtico observado na unidade VI, subfácies 3.1. da T11. Fotomicrografia em PPL.

\subsection{6. - Cinzas}

Ao analisar-se macroscopicamente a micromassa das arqueofácies e subfácies identificadas, chamou a atenção um componente cuja identificação aparentava ser inconfundível e que deveria ter sido igualmente reconhecido no nível microscópico: as cinzas de madeira. A subfácies 2.1 foi definida em campo precisamente pelo conteúdo majoritário de cinzas na sua composição, diferentemente da arqueofácies 2, que parecia ser predominantemente carbonosa. Uma observação semelhante levou à diferenciação em campo da subfácies 3.1 em relação à arqueofácies 3. Porém, em absolutamente nenhuma das lâminas analisadas correspondentes a estas subfácies, ou correspondentes a qualquer outra, conseguiu-se identificar cinzas de madeira ao microscópio.

Para entender melhor as causas deste fenômeno, repassa-se a origem e o processo de formação das cinzas. As cinzas compõem-se majoritariamente de tecidos de plantas queimados que podem se apresentar sob a forma de agregados microcristalinos de carbonato de cálcio, estruturas de sílica inalterada, escória vesicular vitrificada e material criptocristalino (Canti 2003: 341). O componente majoritário das cinzas são os agregados microcristalinos (de cristais romboédricos de 10-30 $\mu \mathrm{m}$ ) denominados de "pseudomorfos de oxalato de cálcio em calcita" (POCC). Os cristais de oxalato de cálcio produzem-se normalmente nas plantas, principalmente nas folhas, e são constituídos de oxalato de cálcio mono-hidratado (whewelita $\mathrm{CaC}_{2} \mathrm{O}_{4} \cdot \mathrm{H}_{2} \mathrm{O}$ ), ou bihidratado (a weddelita $\mathrm{CaC}_{2} \mathrm{O}_{4} \cdot 2 \mathrm{H}_{2} \mathrm{O}$ ). Quando as plantas são queimadas a temperaturas 
entre 400 e $600^{\circ} \mathrm{C}$, estes cristais são completamente oxidados. Após o resfriamento e a re-hidratação, absorvem $\mathrm{CO}_{2}$ da atmosfera e recristalizam em carbonato de cálcio mantendo as características morfológicas do cristal original, o que resulta nos denominados POCC. A partir dos $600^{\circ} \mathrm{C}$, os POCC transformam-se progressivamente em cal (Brochier 1983a, 1983b, 2002, Courty 1983; Courty et al. 1989; Courty \& Fedoroff 2002; Canti 2003).

Estes pseudomorfos de oxalato de cálcio são escuros em luz plano-polarizada e apresentam cor de interferência de primeira a segunda ordem em luz polarizada cruzada (Courty et al. 1989; Canti 2003). Nenhum atributo óptico que indicaria a presença deste componente das cinzas vegetais tem sido reconhecido na camada escura em nenhuma das arqueofácies analisadas, nem na T10 nem na T11.

Porém, outro componente importante das cinzas foi efetivamente identificado ao longo dos perfis analisados: os fitólitos.

Os fitólitos, por sua composição (opala), resistem às temperaturas moderadas freqüentemente alcançadas nas fogueiras antrópicas $\left(400-600^{\circ}\right.$ C) e tendem a permanecer nas cinzas quando as plantas são queimadas (Dimbleby 1967; Brochier 2002). Começam a sofrer modificações já a partir dos 600 a $800^{\circ} \mathrm{C}$, portanto a temperaturas muito mais baixas que as do ponto de fusão da sílica $\left(1713^{\circ} \mathrm{C}\right)$. Isto se deve ao fato de que a presença de materiais alcalinos nas cinzas ou no depósito onde está sendo realizada a queima reduz consideravelmente a temperatura de derretimento da sílica biogênica (Canti 2003). Se as condições químicas de pH são favoráveis, temperaturas maiores que $800^{\circ} \mathrm{C}$ podem acabar derretendo os esqueletos silicosos dos fitólitos, transformando-os em massa amorfa esponjosa de porosidade vesicular (Courty et al. 1989; Courty \& Fedoroff 2002).

A presença conjunta de $\mathrm{CaCO}_{3}$ (POCC) e restos silicosos (fitólitos ou escória vítrea produzida pelo derretimento da sílica biogênica) permite reconhecer a existência de cinzas num depósito. Ambos componentes podem aparecer com cor cinza ou marrom, sob luz plano-polarizada, em virtude de contaminação por carbono não queimado (Courty et al. 1989; Stoops 2003). Porém, os POCC são birrefringntes a polarizadores cruzados, enquanto os fitólitos são totalmente isótropos. Ambos conformam o componente principal das cinzas.

Porém, quando a percolação de água é intensa num depósito, com a passagem do tempo o único resíduo das cinzas que pode sobreviver são os materiais com taxas de dissolução ínfimas na escala arqueológica, microcarvões, óxidos de Fe e outros minerais 
queimados junto com a planta (Canti 2003). Assim, os microcarvões, geneticamente associados aos POCC e aos fitólitos, representam o tipo mais comum de partícula sedimentar antrópica resultado da queima de restos vegetais (Brochier 2002: 457) por terem maior resistência aos processos de intemperismo; de fato, a camada preta é especialmente rica nestes materiais.

Portanto, os vários componentes das cinzas têm solubilidades diversas e lixiviamse diferencialmente nos sítios a céu aberto. Os primeiros a lixiviar são sempre os carbonatos e hidróxidos de sódio e potássio, seguidos pelos $\mathrm{CaCO}_{3}$ e finalmente pelos restos silicosos. A velocidade deste processo depende principalmente das condições de pH do depósito. Em condições alcalinas, como depósitos ricos em calcita por exemplo, a sílica dissolve rapidamente enquanto permanecer rodeada de $\mathrm{CaCO}_{3}$. Pelo contrário, em condições ácidas, todo o $\mathrm{CaCO}_{3}$ é facilmente dissolvido e os componentes silicosos derivados das cinzas são os que permanecerão por mais tempo no depósito (Etiegni \& Campbell 1991; Schiegl et al. 1996; 1996; Canti 2003).

A ausência dos pseudomorfos de oxalato de cálcio na camada preta pode estar relacionada a dois elementos chave: a possível dissolução sofrida pelos POCC, muito sensíveis à remoção pela água dada sua fina granulação (nesse caso eles podem reprecipitar em outro lugar no perfil) (Brochier et al. 1992; Schiegl et al. 1994; 1996; Karkanas et al. 2000; Brochier 2002; Weiner et al. 2002); ou o fato de que as cinzas de gramíneas são ricas em $\mathrm{Si}$ e pobres em $\mathrm{Ca}$ e não contêm nenhum POCC na sua composição, ao contrário das cinzas de madeira, ricas em Ca e pobres em Si (Canti 2003: 357).

Uma arqueofácies cinzenta, como as subfácies 2.1 e 3.1 junto com a unidade IA, onde os cristais de POCC estão ausentes, pode resultar não da queima de madeira e sim da queima de gramíneas. De fato, grande parte dos fitólitos identificados na análise micromorfológica corresponde a fitolitos da epiderme de gramíneas, que se encontram misturados numa micromassa castanho-amarela. As cinzas produzidas pela queima de gramíneas são consideravelmente menos homogêneas que aquelas derivadas da queima de madeira. Em luz plano-polarizada, costumam apresentar micromassa fosfática marrom amarelada com altas quantidades de fitólitos; a altas temperaturas (maiores que $600^{\circ} \mathrm{C}$ ) quando toda a matéria orgânica é destruída, estas cinzas consistem unicamente em resíduos silicosos branco acinzentados (Courty et al. 1989). Ambas as situações foram efetivamente observadas na camada preta, principalmente na subfácies 3.1 e na unidade IB. 
Porém, deve se levar em consideração que a presença de fitólitos num depósito não necessariamente indica a queima de materiais vegetais, como seria o caso dos carvões, microcarvões, POCC e escória vítrea. Os fitólitos podem estar igualmente representando a fração mais resistente à degradação intempérica dos materiais vegetais no depósito. No caso da camada preta, seria a associação constante no perfil de fitólitos de gramíneas com carvões, microcarvões e escória vítrea o que aponta à interpretação da queima de gramíneas como uma atividade recorrente. Não obstante, isto não significa que parte destes esqueletos silícios seja efetivamente o remanescente de espécies vegetais decompostas.
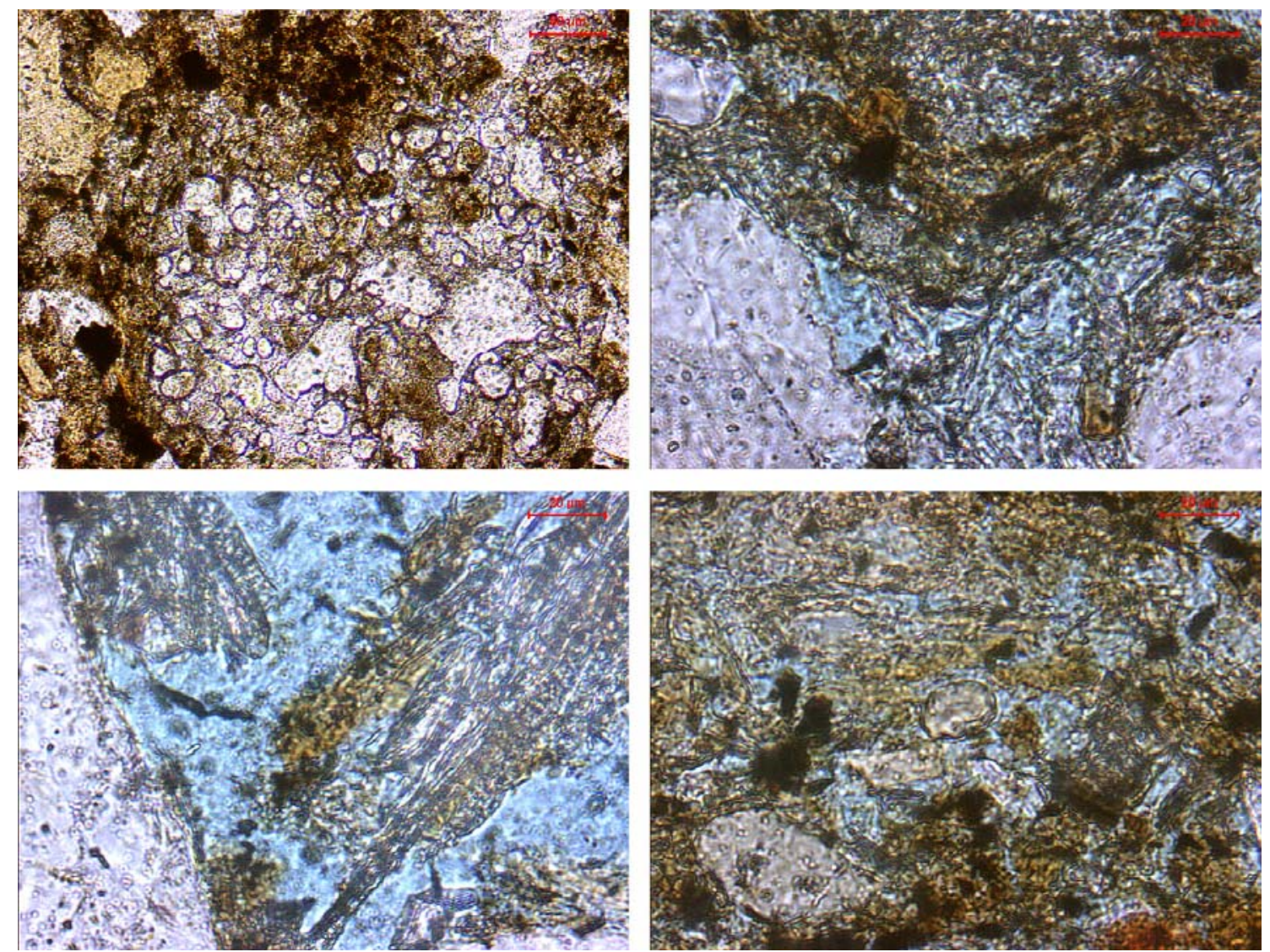

Fig. 42. - Exemplo de escória vítrea (glassy slag) na unidade IA (superior esquerda). A formação desta escória vítrea é um fenômeno de pequena escala que costuma acontecer na zona de maior temperatura de uma fogueira. As três fotografias restantes mostram restos de sílica derivados de plantas na subfácies 3.1 (unidade VI) da T11. 
Portanto:

Na camada preta existem evidências de queima de gramíneas como atividade recorrente ao longo da sua construção. Os restos de sílica derivados da queima de gramíneas estão mais conspicuamente representados nas subfácies 2.1 e 3.1, identificadas em campo pelo seu conteúdo majoritário de cinzas.

Porém, na camada preta os carvões de madeira constituem um componente constante nestes sedimentos arqueológicos, e representam uma inconfundível evidência de que fibras de madeira estavam sendo efetivamente queimadas no local. Portanto, o que aconteceu com os POCC associados à queima da madeira?

Fig. 43. - Variação da solubilidade da sílica com $\mathrm{pH}$ a $25^{\circ} \mathrm{C}$. A linha sólida representa a solubilidade da sílica amorfa (opala) determinada experimentalmente. A linha pontuada representa a solubilidade calculada do quartzo. Adaptado de Karkanas et al. (2000: 924).

$\mathrm{Na}$ figura 43, pode-se observar como a opala é praticamente insolúvel a $\mathrm{pH}$ ácido, especialmente entre 6 e 7 , e é dissolvida rapidamente quando o $\mathrm{pH}$ se torna alcalino (maior que 8,5). Ambientes ricos em cinzas frescas de madeira (altamente alcalinas, $\mathrm{pH}$ entre 9,0 e 13) oferecem condições

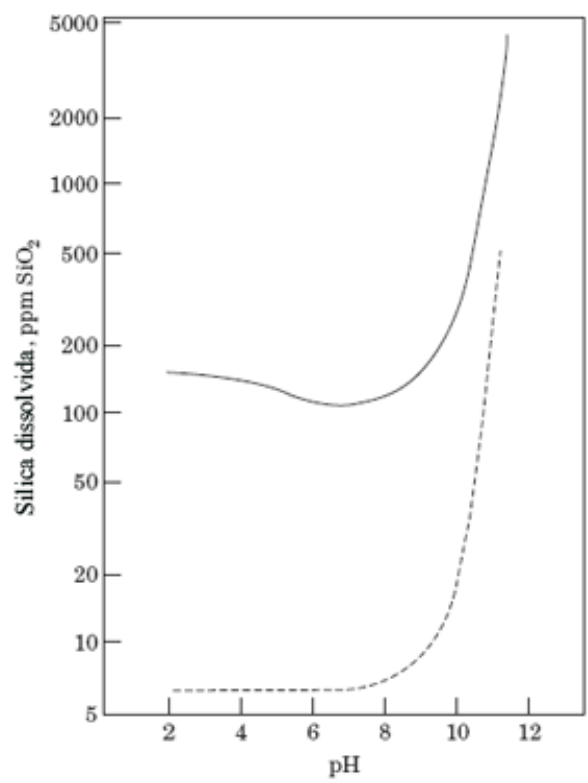
favoráveis para a dissolução da sílica e para a preservação dos POCC no depósito.

Atualmente a camada preta apresenta valores de $\mathrm{pH}$ neutros a ácidos e sua alta porosidade favorece a percolação de água e a intensa lixiviação de solutos. A presença exclusiva de fitólitos e microcarvões, junto com a evidência apresentada no tópico 5.4 sobre a formação de apatita autígena na camada escura, constituem indícios indiretos para inferir que as condições hidrológicas e de $\mathrm{pH}$ do depósito no passado teriam sido semelhantes ou inclusive mais ácidas que às atuais. Um regime hidrológico intenso junto com pH neutro a ácido teria favorecido a dissolução da hidroxiapatita dos ossos e sua reprecipitação em apatita autígena no depósito arqueológico. Da mesma maneira, estas condições particulares beneficiaram a dissolução ou a lixiviação dos POCC até outra locação no perfil. 
Como na camada preta existem evidências de queima tanto de gramíneas como de madeira, ambos os tipos de cinzas devem ter estado presentes originalmente no depósito. Devido às condições de pH provavelmente baixo e de intensa percolação por água, os únicos sobreviventes da queima foram os carvões e microcarvões junto com as cinzas de gramíneas, representadas pelos fitólitos característicos desta espécie vegetal. Neste tipo de condições intempéricas/pedogenéticas, os cristais de calcita podem ser totalmente dissolvidos, deixando unicamente uma micromassa indiferenciada, amarela e fosfática, junto com os fragmentos de carvão. Não obstante, esta hipótese não permite descartar a possibilidade de encontrar-se efetivamente POCC, ou uma reprecipitação mais fina deste material, formando agregados micríticos em outras áreas do sítio, onde as condições possam ter sido mais favoráveis à sua preservação.

Uma outra possibilidade pode explicar a ausência dos POCC na camada escura. Em contextos de cavernas, tem sido relatada a alteração da calcita derivada das cinzas em minerais de fosfato. Especificamente, a solução fosfática derivada da dissolução do mineral dos ossos reprecipitaria ao entrar em contato com o carbonato de cálcio das cinzas em hidroxiapatita carbonatada (antiga "dahlita") (Goldberg \& Nathan 1975; Schiegl et al. 1996; Karkanas et al. 2000; Weiner et al. 2002). Ao microscópio óptico, a hidroxiapatita carbonatada é de cor amarela âmbar, tornando-se isótropa e indiferenciada a polarizadores cruzados. Este mineral é formado essencialmente por P e $\mathrm{Ca}$, com quantidades menores de $\mathrm{Si}, \mathrm{K}, \mathrm{Al}, \mathrm{Fe}$ e Mg (Schiegl et al. 1996).

Novamente, as condições de pH são as que ditam a alteração da calcita em apatita, assim como as quantidades de fósforo em solução. Não obstante, a concentração de fosfato requerida para converter calcita em apatita é relativamente baixa a qualquer valor de $\mathrm{pH}$, mas para que esta reação seja continua o suplemento de fósforo deve ser consideravelmente alto (fig. 45) (Karkanas et al. 2000). 


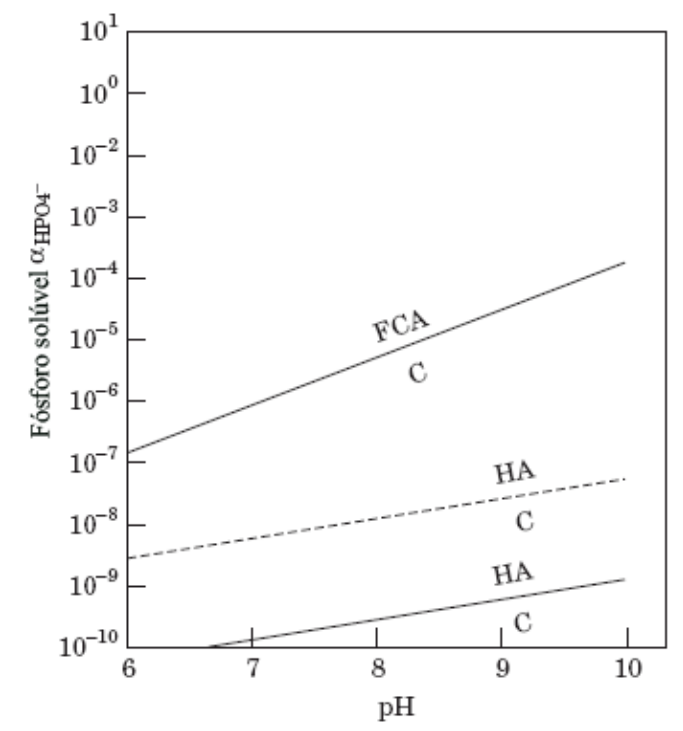

Fig. 44. - Condições limites para a alteração de calcita (C) em hidroxiapatita (HA) e apatita flúor-carbonatada (FCA) segundo Nriagu (1976) e Veillard et al. (1979). Adaptado de Karkanas et al. (2000: 922).

Se os ossos são depositados junto com a calcita, como ocorre quando se associam a cinzas de madeira, então devem permanecer estáveis enquanto a calcita se mantiver presente, não dissolvida (Berna et al. 2004). Quando as condições são favoráveis para a dissolução tanto de calcita como de apatita, então o fosfato entra na solução intersticial do sedimento e pode se combinar com a calcita ainda não dissolvida para recristalizar em apatita carbonatada neoformada.

Não obstante, situações deste tipo têm sido estudadas unicamente em sítios em cavernas, onde o próprio substrato é rico em minerais carbonáticos autóctones de origem ortoquímica, aos quais são adicionados os restos arqueofaunísticos e os POCC. Em sítios a céu aberto compostos por sedimentos arqueológicos antropicamente transportados, não se dispõe de estudos que permitam confirmar este tipo de situação. Deste modo, estudos mais aprofundados sobre a mineralogia da camada preta poderão esclarecer os dados que neste trabalho se apresentam como mera hipótese.

Portanto, agrupando os múltiplos elementos do registro microscópico que foram discutidos ao longo deste tópico, pode se chegar à seguinte conclusão:

A camada escura representa um sedimento arqueológico conformado majoritariamente por uma remobilização de elementos termicamente alterados, e não por materiais queimados in situ. 


\subsection{7. - Diatomáceas}

Durante a análise das secções delgadas das arqueofácies das trincheiras 10 e 11 foram identificadas diversas espécies de diatomáceas. Com o intuito de aprofundar na identificação das diferentes espécies que estão representadas na camada preta foram elaboradas lâminas especiais para tal análise. A doutoranda Paula Amaral do Instituto de Geociências (IGc/USP) auxiliou na confecção das lâminas e realizou a identificação de espécies ao microscópio óptico.

Foi elaborada uma lâmina por trincheira, correspondente à arqueofacies 3 (unidade III) na T10 e à subfácies 3.1 (unidade VIII) na T11. As figuras 45 y 46 apresentam as diversas espécies identificadas.

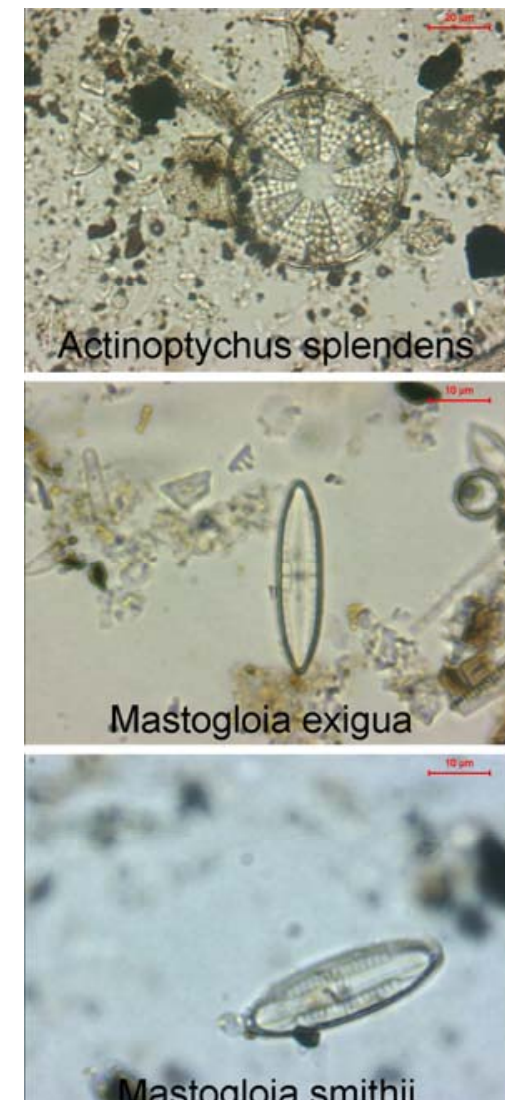

lastogloia smithii
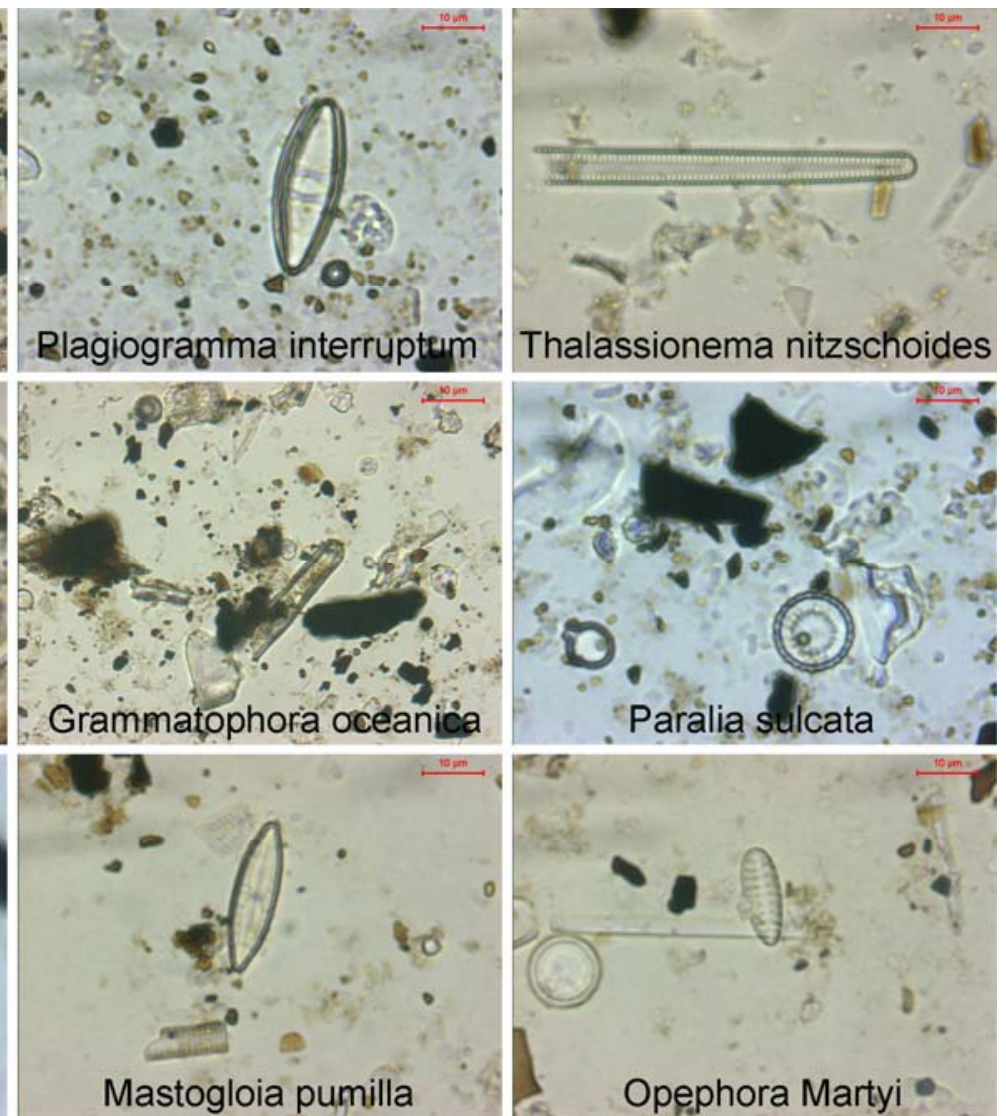

Fig. 45. - Espécies de diatomáceas identificadas na T10 e T11. 


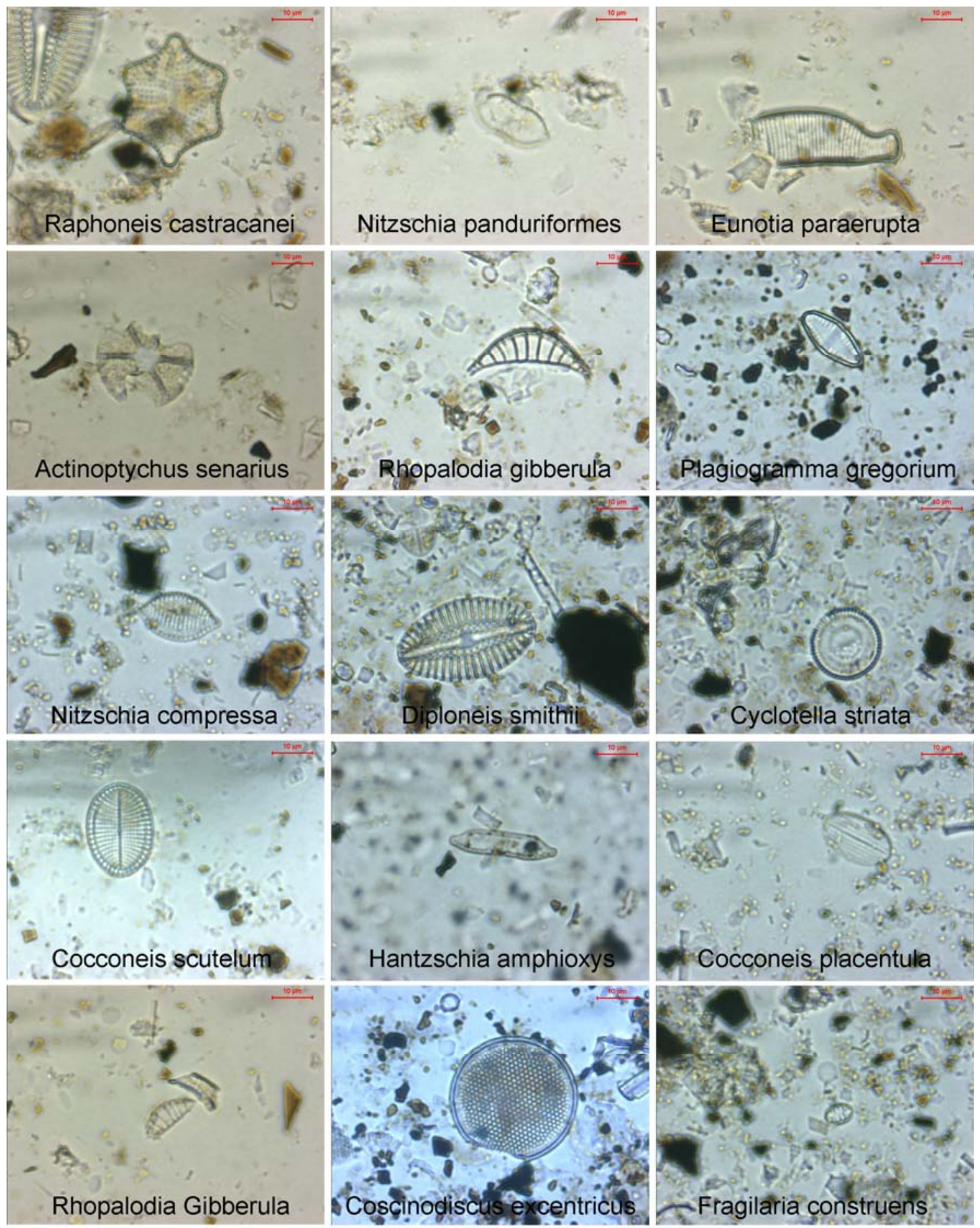

Fig. 46. - Espécies de diatomáceas identificadas na T10 e T11.

A grande maioria das espécies identificadas na camada preta correspondem com espécies que habitam ambientes marinhos litorais e estuarinos, toleram variações na salinidade das águas e são cosmopolitas. Exemplo destas espécies são Actinoptychus vulgaris, Plagiogramma interruptum, Plagiogramma gregorium, Diploneis smithii, Cyclotella striata, Grammatophora oceânica, Nitzschia compressa, Cocconeis placentula. Já as espécies Rhopalodia gibberula, Eunotia paraerupta e Hantzschia 
amphioxys são espécies de água doce ou levemente salobras com alta tolerância a variações na temperatura das águas.

As lâminas de diatomáceas realizada neste trabalho foram exclusivamente para identificação das espécies presentes no depósito. O caráter expeditivo deste estudo somente permitiu corroborar que a assembléia de diatomáceas observada na camada preta é coerente com o ambiente de localização do sítio, embora sua presença no depósito arqueológico não se deva a processos de transporte naturais. Estudos mais sistemáticos que combinem uma amostragem completa nos perfis com a quantificação das diversas espécies identificadas, permitirão inferir o verdadeiro valor interpretativo destes organismos.

\section{6. - Microscopia Eletrônica de Varredura}

Nas figuras 47, 48, 49 e 50, apresentam-se as imagens obtidas com o sensor de elétrons retroespalhados das diferentes seções e amostras brutas analisadas. Os números assinalados nas imagens indicam a localização dos pontos submetidos à análise com o EED.

A análise química semiquantitativa realizada a partir das imagens das figuras 47 , 48 e 49 permitiu determinar que na composição aproximada dos restos arqueofaunísticos da camada escura predominam Ca ( 20\%), C ( 15\%), O ( 30\%), P $(\sim 10 \%)$, Si $(\sim 1 \%)$ (porcentagens em massa), com quantidades menores de $\mathrm{Na}, \mathrm{Mg}$ e Fe. Isto indica que vários dos componentes característicos dos ossos já não formam mais parte da sua composição atual, como o K, Mn, Sr, entre outros. Isto pode ser resultado da queima destes materiais ou das alterações intempéricas sofridas com o decorrer do tempo no depósito.

A micromassa preta, monomorfa e amorfa (fig. 48 e 49) mostrou-se composta majoritariamente de C ( 50\%), O ( 30\%), Si ( 10\%) e Ca ( 2\%), com concentrações menores que $1 \%$ de $\mathrm{Na}, \mathrm{Mg}, \mathrm{K}$ e $\mathrm{Fe}$, em ordem decrescente. Isso confirma sua composição predominantemente carbonosa, embora também apresente uma mistura com outros materiais que aportam em menor magnitude os diversos elementos identificados. 
Já a micromassa castanho-amarela, polimorfa e indiferenciada (fig. 50), previamente descrita como de natureza fosfática confirmou estar composta basicamente de $\mathrm{P}$ e $\mathrm{Ca}$, com teores menores de $\mathrm{Mn}, \mathrm{Mg}, \mathrm{Si}, \mathrm{Na}, \mathrm{Fe}, \mathrm{Cl}$ e Al. Porém, a mesma apresentou uma composição dominada por uma forte mistura de materiais até na escala micrométrica.
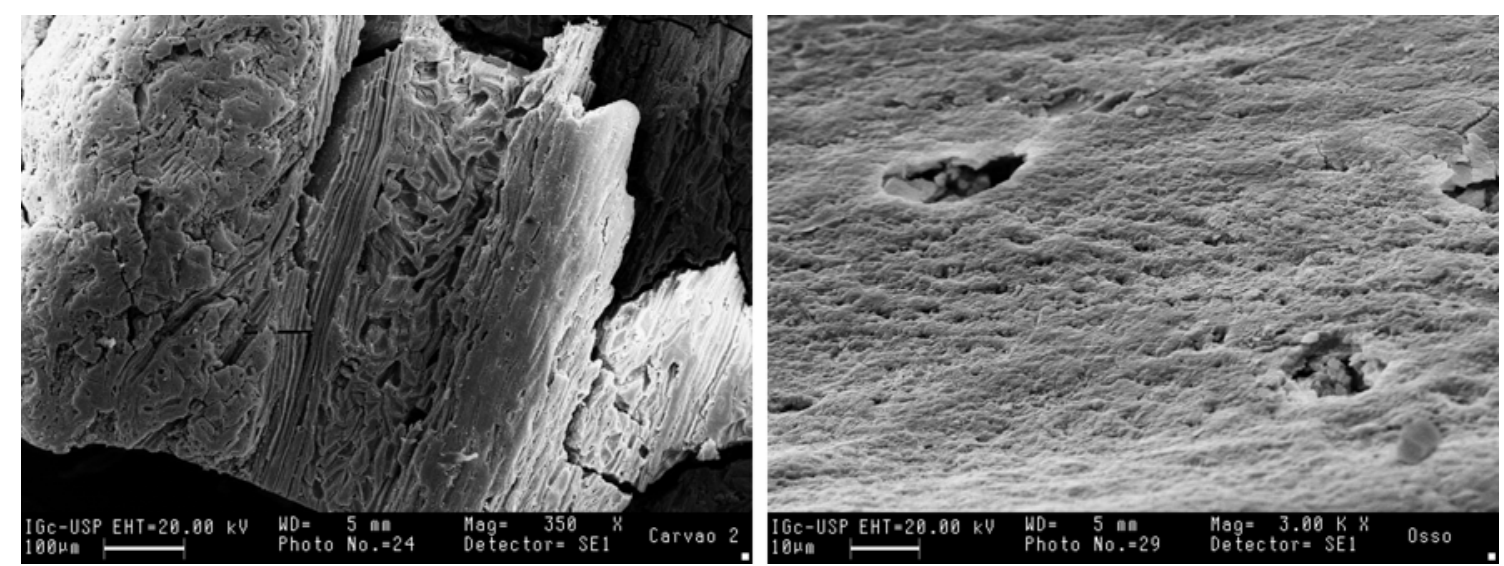

Fig. 47. - Fotomicrografias obtidas com sensor de elétrons secundários nas superfícies de fragmentos de carvão (esquerda) e da superfície de um fragmento de osso (espinha) (direita) recuperados da camada preta.

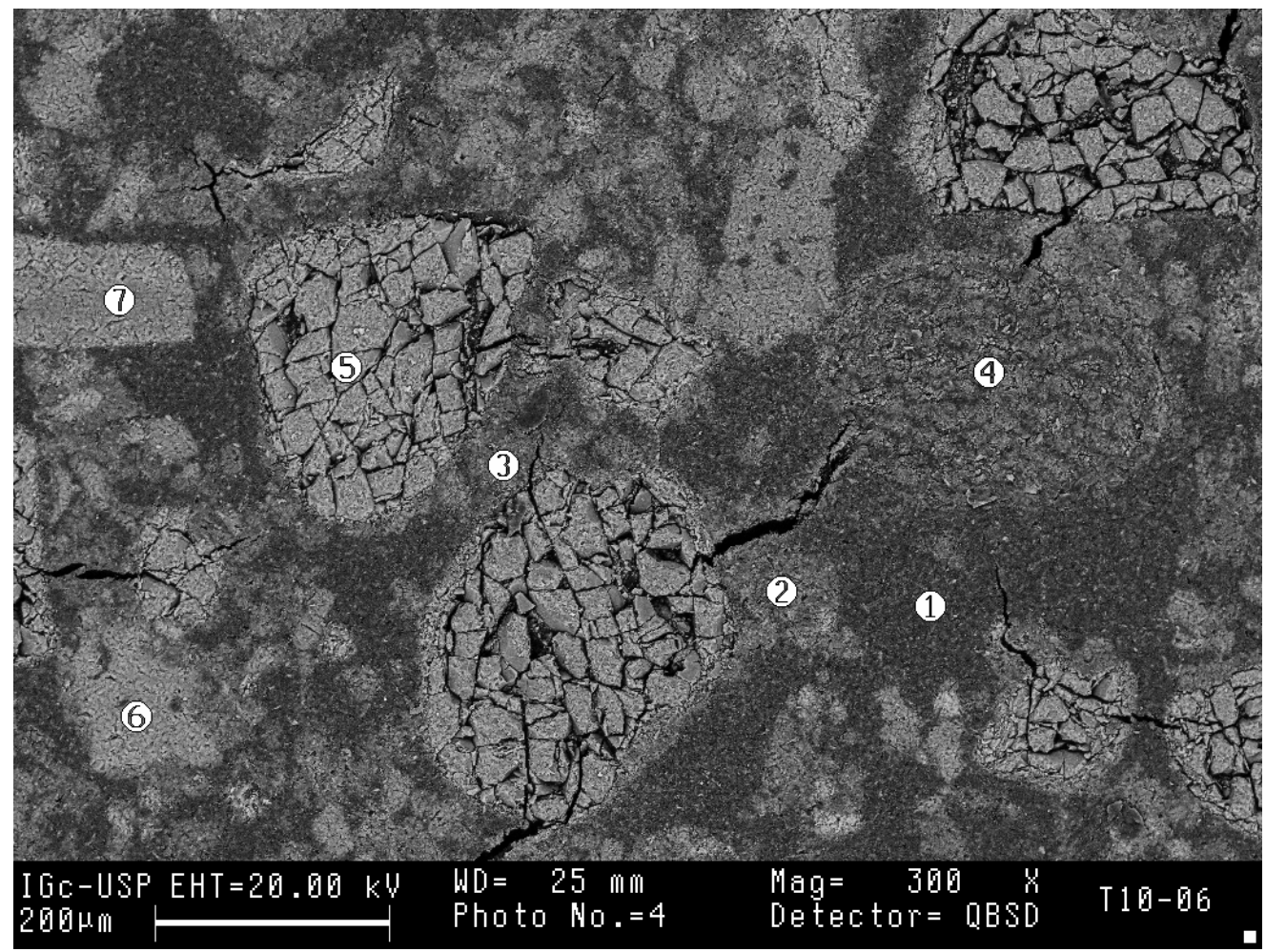

Fig. 48. - Imagem obtida com o sensor de elétrons retroespalhados (QSBD) da arqueofácies 2, T10. Os números 1 e 4 correspondem à resina e ao bálsamo utilizados na laminação; 2 e 3 correspondem à micromassa preta monomorfa amorfa; 5 é grão de quartzo com fragmentação produzida provavelmente durante a laminação; 6 e 7 são fragmentos de osso. 


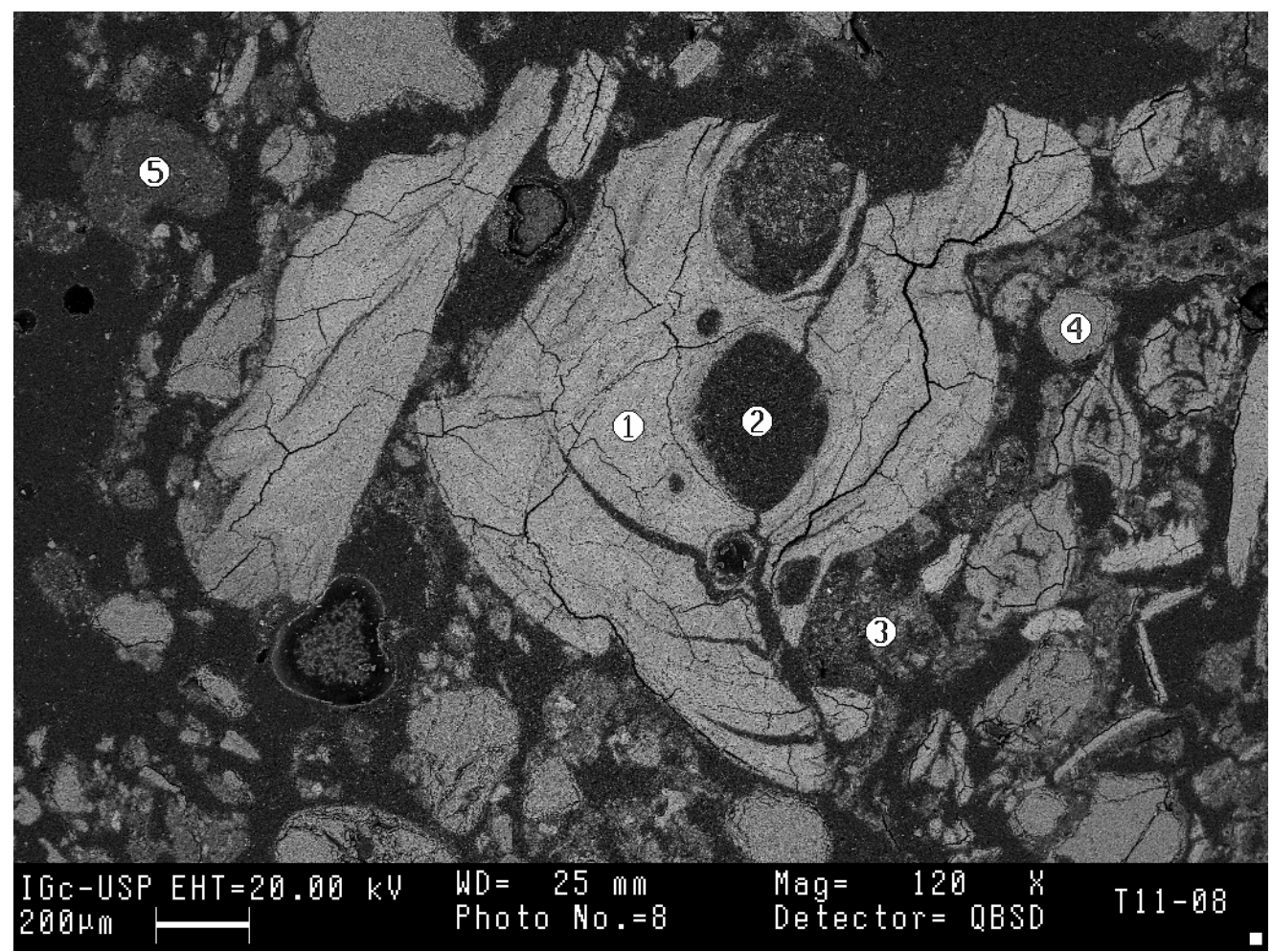

Fig. 49. - Imagem obtida com o sensor de elétrons retroespalhados na subfácies 2.1, T11. O ponto 1 corresponde a fragmento de osso, 3 e 5 à micromassa preta, monomorfa, amorfa, e 4 a grão de quartzo.

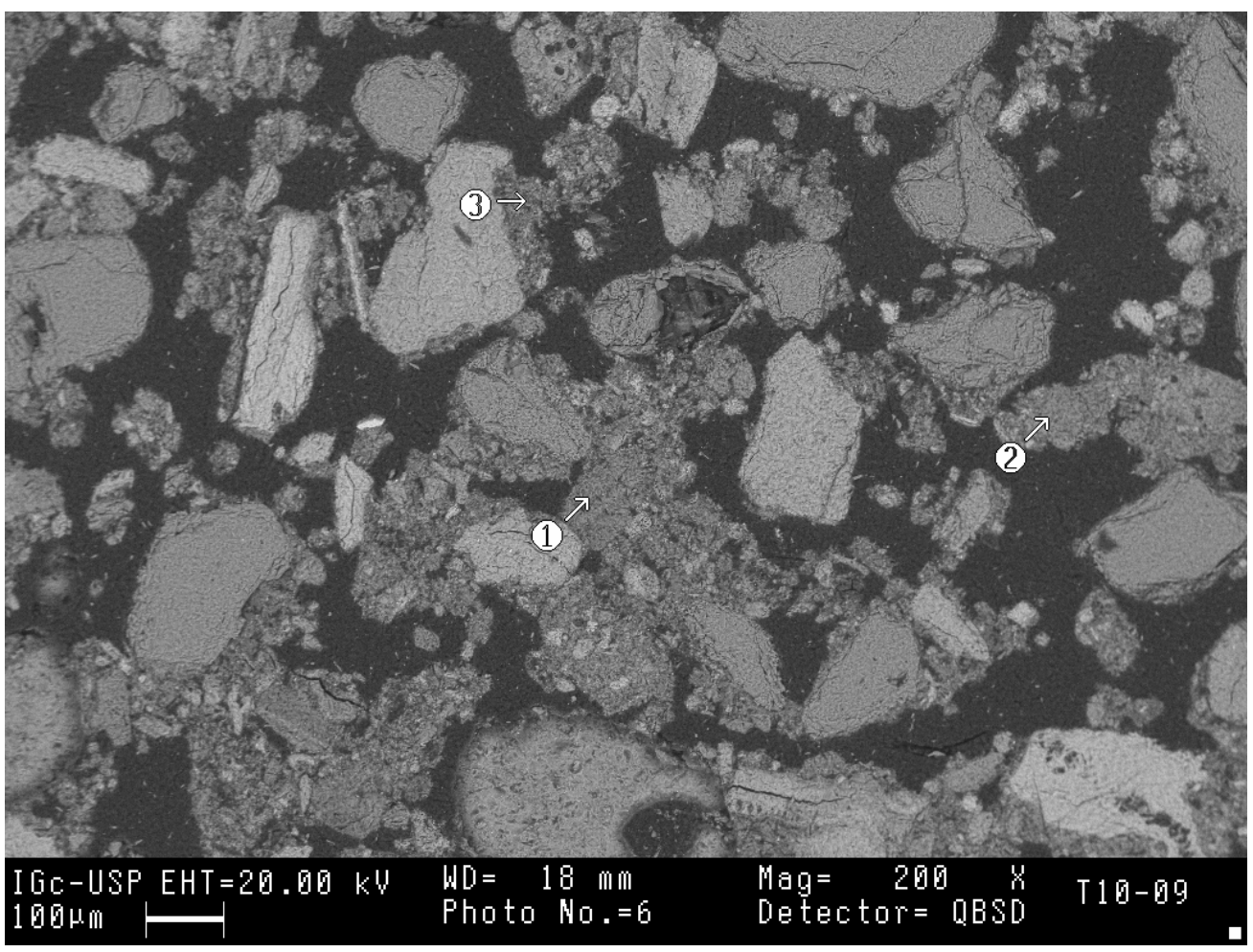

Fig. 50. - Imagem obtida com o sensor de elétrons retroespalhados na arqueofácies 1, T10. Os três pontos assinalados correspondem à micromassa castanho-amarela polimorfa indiferenciada. 
CAPÍTULO VI: CONCLUSÕES 
O objetivo teórico deste trabalho resultou no estabelecimento de um método de estudo arqueoestratigráfico que permite extrair da seqüência vertical informações relativas aos processos de formação de sítio. Embora derivado da geoarqueologia, subdisciplina tradicionalmente associada aos processos naturais de alteração do registro arqueológico, este método não se limita ao estudo dos aspectos pós-deposicionais, mas pretende igualmente ingressar no contexto sistêmico para inferir comportamentos deposicionais.

O eixo principal do método é a definição das denominadas arqueofácies, materialização da ação conjunta de processos antrópicos e naturais vinculados a comunidades passadas. As arqueofacies podem ser consideradas ferramentas para a descrição e interpretação do registro arqueológico. A análise de arqueofácies definida envolve três etapas fundamentais: descrição detalhada em campo dos atributos das unidades arqueoestratigráficas identificadas no perfil (com base em critérios como composição, geometria externa, estruturas internas, conteúdo orgânico, componentes antrópicos); caracterização no laboratório das suas propriedades físicas, químicas, mineralógicas, micromorfológicas, micropaleontológicas etc.; e respectiva interpretação, em termos de processos naturais, deposição cultural e comportamentos humanos.

Neste trabalho, a análise de arqueofácies foi utilizada no estudo dos processos de formação do sambaqui Jabuticabeira II, interpretado como um sítio cemitério caracterizado por envolver uma dinâmica construtiva materializada por dois corpos arqueossedimentares sucessivos no tempo: a camada conchífera e a camada preta. A camada preta, objeto deste trabalho, representaria uma modificação na escolha dos materiais construtivos associados ao ritual funerário.

Desde o começo das investigações no sítio Jabuticabeira II, a camada preta não tem sido alvo principal das pesquisas, e os conhecimentos que até o momento se tinham deste fenômeno de deposição cultural eram sobretudo interpretativos e baseados exclusivamente em aspectos macroscópicos. Com este projeto de mestrado, da-se continuidade aos estudos recentemente desenvolvidos na camada preta (Nishida 2007), com vistas a aprofundar-se no conhecimento e na interpretação deste complexo corpo arqueossedimentar. A partir da aplicação da análise de arqueofácies desenhada, ampliaram-se consideravelmente as informações que se tinham da camada preta e contribuiu-se com interpretações que confirmam antigas suposições, ao mesmo tempo que redirecionam os olhares. 
As arqueofácies definidas neste trabalho corresponderiam com o que Orquera \& Piana (1992) chamam de "fases de formação" dos sítios concheiros, cuja definição é a seguinte:

“.../ cada conjunto de cuasi-unidades de depositación que muestra algunas características predominantes de composición, continuidad estratigráfica (no interrumpida por hiatos marcados) y recurrencia en su localización dentro del sitio" (1992: 34)

Descrição, classificação e caracterização de arqueofácies e subfácies permitiram identificar processos naturais e antrópicos envolvidos na formação destes sedimentos arqueológicos, assim como estabelecer similaridades e diferenças entre as arqueofácies que, a partir do arranjo espacial das mesmas, possibilitam a interpretação na seqüência vertical de associações de arqueofácies. Estas associações expressam a mudança ou permanência de arqueofácies em termos de eventos que podem estar relacionados com o grau de preservação do estado de deposição inicial, ou que podem corresponder ou não a uma mesma dinâmica deposicional.

\section{1. - Síntese das informações descritivas}

Múltiplas linhas de evidências foram trabalhadas na análise de arqueofácies para oferecer uma interpretação completa dos fenômenos que envolve a camada preta. Estas diferentes linhas de evidências, incorporadas nas várias análises estipuladas para a caracterização de arqueofácies, ofereceram um conjunto de inferências vinculadas com a dinâmica antrópico-natural deste corpo arqueossedimentar.

Numa primeira abordagem macroscópica visual das arqueofácies que compõem a camada preta, tal como se apresenta nas trincheiras 10 e 11, podem-se observar diferenças relacionadas principalmente à coloração e a composição dos sedimentos, que permitiram a distinção de cinco arqueofácies e três subfácies. Quanto à composição das arqueofácies e subfácies identificadas, a caracterização posterior permitiu reconhecer um conjunto de componentes comuns a ambas as seções verticais estudadas. A camada preta foi então particularizada como combinação de componentes de caráter natural, representado pelas areias terrígenas quartzosas, e componentes vinculados a atividades 
culturais, representados pelos restos arqueofaunísticos e carvões. Tanto as análises granulométricas como as análises químicas e micromorfológicas respaldaram esta identificação.

As areias quartzosas representam mais de 50\% da composição destes sedimentos arqueológicos e sua origem estaria vinculada a depósitos paleolagunares como os que caracterizam a área de localização do sítio. Suas características texturais indicam um tipo de transporte que não corresponde ao dos demais elementos da fração grossa. Ossos e carvões parecem não ter sofrido qualquer tipo de transporte por agentes naturais e sua presença conjunta no depósito antrópico, junto com as areias paleolagunares, indica que todos estes elementos foram depositados pelo mesmo agente de natureza antrópica.

A relação genética entre os sedimentos paleolagunares e a camada escura, inferida na base de critérios texturais e de cor, demonstrou não ser tão direta. A maior semelhança que estes sedimentos arqueológicos guardam com a paleolaguna refere-se às areias terrígenas quartzosas que contêm e a textura delas. Quanto a outros componentes dos sedimentos paleolagunares, filossilicatos e $\mathrm{MO}$, o vinculo com estes sedimentos naturais torna-se menos evidente. A ausência ou o baixa quantidade de filossilicatos registrada atualmente na camada preta, pode estar ligada à lavagem que estes minerais sofreram. Igualmente, os baixos teores de MO dos sedimentos arqueológicos, que muito contrastam com os valores nos sedimentos paleolagunares, podem se dever ao mesmo processo de lavagem.

Ossos e carvões têm a particularidade de estar representados em quase a totalidade das frações granulométricas da camada escura, desde cascalho até argila. Os microcarvões presentes em todas as arqueofácies estão relacionados à queima de madeira e aos fragmentos microscópicos de ossos carbonizados, e perfazem parte importante da micromassa da camada preta. A presença de apatita na fração argila está vinculada com a reprecipitação do fosfato dissolvido nos ossos, na forma de fosfomicrita autígena, fenômeno favorecido pelas condições de $\mathrm{pH}$ e regime hidrológico do depósito.

Os restos arqueofaunísticos, componente mais conspícuo da camada preta, foram expostos à ação direta do fogo uma vez consumida sua carne até alcançar, em vários casos, o estado de carbonização e calcinação. Este grau de alteração térmica é atingido nos ossos de peixe a temperaturas maiores que $300^{\circ} \mathrm{C}$ e só através da proximidade imediata com a fonte de calor. Portanto, estes resíduos alimentícios teriam sido 
intencionalmente queimados o que favoreceu sua debilitação estrutural e a alta fragmentação sofrida pelo transporte antrópico ou pelo pisoteio após a depositação.

Os materiais vegetais, longamente relegados a segundo plano nas pesquisas arqueológicas, demonstraram-se altamente representados na camada preta. $\mathrm{Na}$ forma de carvões, microcarvões, fitólitos, escória vítrea etc., estes resíduos vinculados à queima de plantas são imperceptíveis a olho nu, mas surpreendentemente conspícuos na escala microscópica. A queima de madeira e gramíneas foi aparentemente uma atividade recorrente ao longo da construção da camada preta. Seus resíduos acham-se entremisturados com os restos faunísticos e os grãos de quartzo, que ao mesmo tempo também apresentam evidências de terem sofrido a ação do aquecimento, certamente por fogueiras antrópicas.

Os carvões e microcarvões associados à queima de madeiras podem-se vincular à utilização deste material vegetal como combustível para as fogueiras, assim como aqueima de gramíneas. Não obstante, a presença de gramíneas pode também indicar sua exploração como recurso alimentício por parte estas populações, ou uma possível atividade de fabricação de cestos e tecidos a partir do uso de fibras vegetais. Diferentemente da escória vítrea, a presença de fitólitos não está unicamente relacionada ao aquecimento de materiais vegetais. Grande parte destes esqueletos silicosos pode representar os restos resistentes de materiais vegetais degradados naturalmente no depósito, e não necessariamente queimados.

Os fitólitos são um componente de destaque na camada preta. Como as gramíneas são grandes produtoras de fitólitos, as formas correspondentes a esta família foram as mais claramente identificadas na seção delgada. Porém, as lâminas de diatomáceas evidenciaram igualmente a presença de uma variedade ainda maior de formas. Considera-se de importância primordial a realização de um estudo específico destes materiais silicosos na camada preta que contemple a quantificação e a identificação dos diferentes tipos de fitólitos existentes. Um estudo dessa natureza fornecerá informações importantes sobre a exploração de recursos vegetais por parte das populações sambaquieiras, tanto como matérias primas na produção de bens de uso, como com fins de consumo.

Materiais vinculados com atividades humanas são constantes ao longo das seções verticais trabalhadas. Sua proporção relativa nas arqueofácies e subfácies identificadas estaria vinculada a comportamentos deposicionais diferenciais na construção deste 
corpo arqueossedimentar, vinculados as proporções de restos arqueofaunísticos e carvões.

Estas diferenças estariam vinculadas a comportamentos deposicionais e não a processos pós-deposicionais naturais (pedogênicos), e referem principalmente á composição da micromassa. Porém, o fato de as alterações pedogênicas se apresentarem em proporção relativamente constante na camada escura, da base até o topo, sugere que: a pedogênese afetou equitativamente à totalidade do depósito uma vez constituído como tal; ou não existiram hiatos temporais longos entre a deposição das diferentes arqueofácies que possam ter motivado uma pedogênese diferencial entre os episódios deposicionais.

Dada a natureza antrópica da camada preta, em termos de transporte e deposição, tanto os encobrimentos, como os nódulos anórticos e até parte dos possíveis excrementos identificados podem ser também elementos herdados e não exclusivamente desenvolvidos no local. Porém, no caso dos encobrimentos, grande parte deles apresenta-se em cúpula ou em pendulo o que sugere sua formação efetivamente in situ. Já os nódulos anórticos parecem mesmo ser elementos herdados.

\section{2. - Depósitos secundários e terciários}

Vários dos atributos micromorfológicos identificados na camada preta permitem associar estes sedimentos arqueológicos com aqueles provenientes de depósitos de descarte secundário (sensu Schiffer 1972, 1983, 1987). O conceito de depósitos ou sedimentos secundários representa uma extrapolação, para o registro arqueossedimentar, das propostas de Schiffer para o descarte de restos artefatuais. O descarte, término de vida de uso de um elemento, é um tipo de deposição cultural que pode ser: primária, quando o material foi descartado na sua locação de uso; secundária, quando foi descartado em locação diferente da de uso; terciária, quando removido de áreas de descarte secundário, para reutilização; ou defacto, quando chega ao contexto arqueológico sem ter sido intencionalmente descartado. Os descartes secundário e terciário envolvem necessariamente o transporte prévio ao abandono do elemento 
descartado dentro do contexto sistêmico, enquanto o descarte primário é realizado in situ e está principalmente relacionado com atividades de subsistência.

Os comportamentos deposicionais relacionados com o descarte e o abandono foram longamente considerados obscurecedores do registro arqueológico. Porém, o descarte constitui atividade humana fundamental na dinâmica social (La Motta \& Schiffer 2002). O estudo do descarte que se deriva da análise da camada preta, assim como de outro tipo de deposição cultural, constitui ferramenta valiosa para o estudo dos sistemas comportamentais e organizacionais das sociedades sambaquieiras.

Depósitos ou sedimentos secundários caracterizam-se por apresentar microestruturas com microagregados intergranulares, padrão de empacotamento complexo e componentes distribuídos aleatoriamente, provavelmente resultado da alteração dos materiais grossos e finos durante a coleta, a deposição e a separação enquanto os materiais caem ao solo (Matthews et al. 1997: 289). As áreas de deposição secundária apresentam, em contraste às áreas intensamente usadas, alta concentração de materiais e baixa intensidade de pisoteio (Schiffer 1987: 126), o que se reflete micromorfologicamente nas características anteriormente citadas.

As superfícies de pisoteio ou ocupação caracterizam-se precisamente como finas lentes com microestruturas densas e materiais orientados linearmente e distribuídos paralelamente em relação ao substrato (Goldberg \& Whitbread 1993: 166; Matthews et al. 1997: 289). Tais situações não foram observadas nas seções delgadas da camada preta, porém, isso não permite descartar sua existência, já que a camada preta apresenta evidências de efeitos de agentes intempéricos, os quais podem ter alterado o registro destas superfícies de compactação diferencial.

Os middens são o tipo de depósito secundário identificado na literatura que guarda maiores semelhanças com o observado na camada preta. Trata-se de depósitos formalizados de rejeitos das atividades cotidianas (Beck \& Hill 2004: 305), que tomam a forma de um montículo ou camada espessa rica em restos orgânicos e restos não comestíveis de alimentos (Courty et al. 1989: 118). Needham e Spence (1997: 80) definem os middens como depósitos de ocupação ricos em detritos com evidências de acumulação deliberada e seqüencial de restos num lugar único. Esta definição é similar àquela de Wilson (1994: 44), que define o midden como um agregado de restos secundários ou depósitos localizados de alta densidade, que aparecem como resultado de uma deposição formalizada. Este tipo de depósito caracteriza-se por apresentar tanto macroscópica como microscopicamente maior conteúdo de ossos, conchas, carvão, 
matéria orgânica decomposta, fosfatos (Goldberg \& Whitbread 1992), entre outros componentes derivados dos resíduos cotidianos das populações, todos sem orientação tridimensional preferencial.

Em seção delgada, este tipo de depósito apresenta fragmentos de conchas e ossos dispersos, pobremente empacotados, junto com agregados que misturam material mineral e orgânico. Esta associação de elementos, a angulosidade dos fragmentos, o empacotamento aberto e alta porosidade do depósito permitem separar os middens de assembléias naturais (Courty et al. 1989: 118).

Todas as características descritas anteriormente para depósitos secundários de tipo midden observam-se na camada preta como um todo (incluindo as diferentes arqueofácies e subfácies), inclusive sua composição por lentes correspondentes a episódios de discretos de deposição de materiais queimados (Matthews et al. 1997). Os atributos microscópicos típicos de middens observam-se nas seções delgadas de todas as arqueofácies estudadas, o que sugere que a camada preta poderia tratar-se efetivamente de depósito de este tipo.

Porém, deve-se advertir que o uso do termo midden não resulta apropriado neste contexto, já que enfatiza principalmente o valor material do depósito para a subsistência e tende a mascarar assim o aspecto simbólico da construção na vida cultural das sociedades sambaquieiras. Além disso, falar de middens para referir-se a sambaquis retrocede as investigações deste fenômeno arqueológico às interpretações de começos do século XX, quando se considerava os sambaquis como simples acúmulos de rejeitos alimentícios.

Figuti e Klokler (1996), ao inferir que as camadas de moluscos são produto de uma intenção explícita de construção dos sambaquis, já haviam oposto que estes sítios entrariam na categoria de shell bearing habitation site (Widmer 1989 em Claasen 1991). Este tipo de sítio compõe-se principalmente, mas não exclusivamente, por restos de moluscos, que podem ou não ter sido utilizados originalmente como alimento, mas cujo emprego final é para fins arquitetônicos. Essa categoria de sítio, proposta para os sambaquis de composição predominantemente conchífera, pode ser igualmente aplicada à camada preta, rica em restos arqueofaunísticos.

Igualmente, dois elementos fundamentais na constituição da camada preta impedem associar diretamente estes sedimentos a depósitos de tipo midden: a alta densidade de sepultamentos humanos e a dinâmica construtiva, proposta para o levantamento da camada preta, isto é, sobreposição de pequenos montículos 
estratificados que cobriam, diacrônica ou sincronicamente, diferentes sepultamentos (Klokler \& Gaspar 2004; Bendazzoli 2007; Nishida 2007).

Deste modo, as evidências macro e microscópica induzem à interpretação da camada preta como um depósito de descarte secundário não meramente associado ao rejeito de objetos comestíveis. A análise das diferenças observadas entre as arqueofácies pode auxiliar na explicação desta questão. As principais diferenças vinculam-se com variações na concentração de restos faunísticos, carvão e cinzas.

A maior porcentagem de ossos é encontrada nas arqueofácies 3 e subfácies 3.1, que se intercalam com as arqueofácies 2 e subfácies 2.1. Estas últimas, por sua vez, apresentam ossos, não somente em menor quantidade mas mais carbonizados e calcinados. A concentração diferencial de ossos também se reflete nos teores de fósforo e cálcio, maiores na arqueofácies 3 e subfácies 3.1. que na arqueofácies 2 e subfácies 2.1 .

As evidências de queima em ossos, junto com a alta concentração de carvão e cinzas, poderia indicar duas situações possíveis: que os materiais foram queimados in situ após sua deposição; ou que correspondem aos restos de antigas fogueiras acesas para o cozimento de alimentos, cujos resíduos foram posteriormente arrojados no local.

Se a queima tivesse sido realizada in situ, então a intensidade da temperatura necessária para a calcinação e carbonização dos ossos, assim como para a formação de carvões e cinzas, teria atingido e alterado também os estratos imediatamente inferiores. Isto é assim já que incêndios ou fogueiras em superfície podem alcançar até $5 \mathrm{~cm}$ de profundidade formando um gradiente de alteração dentro do sedimento. Desse modo, ter-se-iam unidades lenticulares ricas em ossos completamente calcinados e carbonizados cujo grau de queima diminuiria conforme aumentasse a distância lateral e vertical do epicentro da fogueira.

As fogueiras são identificadas em campo por apresentar formas arredondadas a ovaladas na seção horizontal, com 40 a $60 \mathrm{~cm}$ de diâmetro, ou por mostrar formas lenticulares na seção vertical, com espessuras que vão de alguns milímetros até dezenas de centímetros no máximo. Reconhecem-se também pela sua coloração diferencial em relação aos sedimentos adjacentes, geralmente com materiais brancos ou cinza claro no topo, uma camada preta ou castanho escura rica em carvão e um substrato de sedimentos avermelhados (Schiegl et al.1994; 1996; Weiner et al. 2002).

Esta situação de fato se observa próximo à base da T11, onde os restos de fogueira são claramente identificados tanto na seção vertical como na exposição horizontal (fig. 
51). Essa fogueira corresponde com à arqueofácies 4 (unidade XIII), lenticular, rígida e rica em carvão e ossos totalmente carbonizados. Esta antiga fogueira in situ efetivamente teria afetado os sedimentos da unidade inferior (unidade XIV, arqueofácies 5), tanto como resultado do calor em superfície como pelo intemperismo diferencial posterior induzido pela presença de seus restos.

Fig. 51. - Fogueira na T11, arqueofácies 4 (unidade XIII). Note-se a forma clara e arredondada da fogueira e sua associação com o sepultamento 139, imediatamente abaixo. Fotos: Paula Nishida.

Nas arqueofácies e subfácies restantes não foram observadas evidências deste tipo nem na seção vertical nem na exposição horizontal. Além disso, elas apresentam misturas de materiais com diversos graus de queima, dentro de matrizes que compreendem micromassas fosfáticas e carbonosas, intercaladas e com limites geralmente abruptos entre si. Esta situação é observada tanto na T11 como na T10.

As diferentes unidades arqueossedimentares que compõem ambas as trincheiras conformariam uma seqüência de episódios deposicionais discretos, dada sua micromassa diferencial, os contatos diretos e as

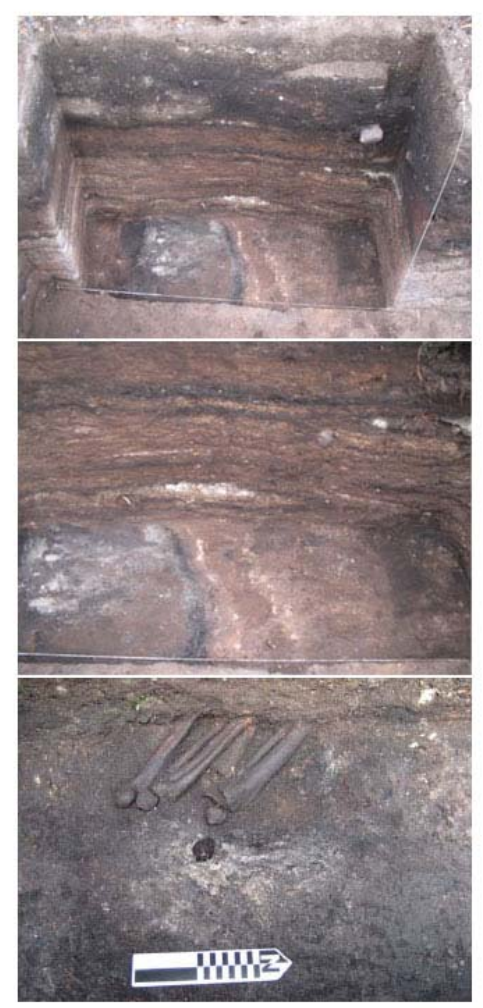
evidências de processos pedogênicos. A presença de várias das arqueofácies em ambos os perfis indica a extensão espacial destes episódios construtivos.

Pelo arranjo, distribuição aleatória e mistura de materiais com diversos graus de alteração térmica, a queima dos componentes macro e microscópicos da camada escura não teria sido produzida in situ (exceto na arqueofácies 4), mas numa locação diferente da deposição final. Assim, os episódios deposicionais representados pelas diferentes arqueofácies, embora ricos em materiais queimados, compreenderiam momentos distintos de remobilização de elementos termicamente alterados.

A repetição intercalada das arqueofácies ao longo dos perfis e seu hábito de recobrimento de sepultamentos humanos está relacionada com uma intencionalidade construtiva diferencial, e não simplesmente com o descarte de resíduos alimentares em depósitos de descarte secundário. A associação de arqueofácies que representam estaria 
refletindo a dinâmica de ocupação e construção da camada preta, caracterizada pela coleta, transporte e deposição antrópica de materiais.

Os materiais de origem biológica da camada preta, ossos e carvões, apresentam claros indícios de integridade comprometida por processos antrópicos não realizados no local (como a queima). Provavelmente, estes materiais foram acumulados originalmente num depósito secundário de tipo midden onde sofreram a ação da queima antrópica e dos agentes intempéricos. Posteriormente, foram retransportados até a camada preta, já com os traços da alteração sofrida, onde foram redepositados de modo a formar a matriz arqueossedimentar altamente misturada.

Interpreta-se a origem doméstica dos restos arqueofaunísticos que compõem à camada preta principalmente devido a sua grande abundancia. Devido à degradação que estes materiais sofreram ao longo do tempo, a quantidade que se observa atualmente no sítio seria consideravelmente inferior à originalmente depositada. A ausência de sítios de habitação vinculados a este grande sambaqui poderia ser explicada como conseqüência desta remobilização de materiais. Isto não exclui a possibilidade de que parte dos restos alimentícios que compõem a camada preta esteja também relacionada aos restos de grandes festins e banquetes rituais. Porém, sua evolução teria sido a mesma.

A associação de arqueofácies representada pela seqüência de micromassas carbonosas e fosfáticas relaciona-se a uma intencionalidade nos diferentes episódios construtivos. Esta intencionalidade estaria vinculada ao ritual funerário, porém, sua matéria prima guardaria relação com o cotidiano das comunidades. Portanto, a camada preta não representa um depósito secundário, mas um depósito construído com os resíduos diretos de atividades vinculadas à subsistência dos grupos dentro de um padrão construtivo vinculado fundamentalmente ao ritual funerário.

Depósitos deste tipo têm sido chamados indistintamente de terciários ou middens secundários (Schiffer 1983, 1987; Courty et al. 1989). Neste ponto da discussão, devese lembrar que classificações de sedimentos arqueológicos que envolvem intenção somente podem ser alcançadas através de um estudo detalhado e sistemático, inserido em método geoarqueológico eficiente. Abordar o registro arqueossedimentar com enfoques interpretativos a priori somente dificulta a apreciação da verdadeira realidade natural e cultural que os sedimentos arqueológicos envolvem.

A camada preta representa um grande depósito arqueológico onde o palimpsesto domina tanto sua conformação como sua configuração final. No seu uso comum em 
arqueologia, o termo palimpsesto refere à superposição de atividades que ocasiona a destruição total ou parcial dos seus restos materiais, e das quais só a última permanece intacta no registro. Não obstante, o palimpsesto pode também envolver a acumulação e transformação de atividades sucessivas parcialmente preservadas, de maneira que o total é diferente e até maior que a os constituintes originais.

Geoff Bailey (2007) define cinco tipos de palimpsesto: o verdadeiro, no qual todo resto de atividades previas é removido, exceto os da mais recente; o cumulativo, no qual os restos de atividades anteriores permanecem superpostos um sobre os outros sem perda de evidências, mas com forte mistura até o ponto de não poder diferenciar os constituintes originais de cada episódio; o espacial, variação do palimpsesto cumulativo definida como mistura de episódios espacialmente separados cuja relação temporal tem se tornado difícil de identificar pela ação de processos de alteração naturais; o temporal, que refere a depósitos compostos por materiais de idades diferentes, mas que correspondem a um mesmo episódio de deposição; e o de significado, que define a sucessão de significados que adquire um objeto ou grupo de objetos como resultado de seus diferentes usos.

A camada preta, portanto, envolve dois tipos de palimpsesto: o cumulativo e o de significado. Os milhares de ossos de peixe, carvões, entre outros componentes, que conformam este grande corpo arqueossedimentar representam uma multiplicidade de episódios de consumo, queima e deposição que comprometem sua resolução temporal individual no nível estratigráfico. Como o espectro de episódios individuais é numeroso, só pode-se observar tendências gerais representadas por este palimpsesto como um todo. Desta maneira, cada arqueofácies e subfácies identificada representaria um timeaveraging de componentes com diversas histórias de vida e, portanto, pouca resolução temporal, já que os restos materiais dos episódios sucessivos de deposição estão intensamente misturados.

Entretanto, na camada preta esta mistura resultou da atividade de remobilização dos materiais construtivos desde um depósito até outro, com a conseqüente transmutação no papel simbólico dos mesmos. Este palimpsesto cumulativo caracterizase por provocar a desaparição do padrão original, o depósito secundário original do qual provêem os materiais, e por simultaneamente criar um padrão final novo, o depósito terciário, resultado do transporte intencional.

Portanto, a camada preta tem a particularidade de incluir o simbolismo e a dinâmica do ritual funerário que caracterizou o sítio Jabuticabeira II desde o começo da 
sua construção, numa estrutura sustentada pelos resíduos das atividades cotidianas. Este comportamento deposicional tão especial, que se nutre dos detritos alimentícios na sustentação do ritual funerário, definiria grande parte do processo construtivo deste sítio.

Os indícios, longamente procurados, de áreas de habitação associadas a esta estrutura de grande porte podem estar mascarados na forma de grandes depósitos rituais. O depósito secundário original onde estes materiais foram acumulados poderia ter estado dentro ou fora do sítio, e poderia igualmente se tratar tanto de estrutura positiva na paisagem (montículo elevado) quanto negativa (escavação no terreno). Os materiais incluídos nestas áreas teriam sido posteriormente coletados para sua redeposição como elemento ritual na camada escura.

O sítio Jabuticabeira II representa a articulação e amalgamação do cotidiano com o ritual, integrando as esferas estruturais e superestruturais numa estrutura que encerra $o$ dinamismo da vida destas comunidades. A abordagem dicotômica que desconecta o registro do dia a dia, concebido como norma, com o mundo ritual, concebido como exceção, não teria permitido, até o momento, apreciar a verdadeira natureza deste fenômeno arqueológico.

A oposição convencional entre ritual e cotidiano não é funcional no estudo do sítio Jabuticabeira II e deriva de visões influenciadas pelos parâmetros da nossa própria cultura:

"How do archaeologists distinguish between ritual and the everyday? /.../ they have done so on a largely intuitive basis, influenced by their experience in an increasingly secular world. It is a world in which ritual and religious belief have been pushed to the margins. /.../ They have seen ritual as something that involved special people, special places and a distinctive range of material culture. They have also assumed that ritual was quite separate from the concerns of daily life. That may not have been true" (Bradley 2003: 13).

Portanto:

Com as evidencias trabalhadas pode se concluir que a camada preta representa a ritualização dos componentes da vida doméstica em torno do ritual funerário. 


\section{3. - Modelo de cadeia comportamental}

No processo de formação da camada preta do sítio Jabuticabeira II estão envolvidos uma serie de comportamentos deposicionais relacionados com atividades de descarte, rituais, cotidianas, entre outras. O registro arqueológico e arqueossedimentar, dentro de um marco de referência antropológico, permitem aproximar os comportamentos deposicionais e vincular estes com a variação na organização das atividades do grupo.

A remoção de elementos das atividades em que participaram, ou deposição cultural, é fundamental na análise de sistemas culturais em arqueologia e na construção de teoria sobre comportamentos deposicionais. A deposição cultural não represente unicamente o produto do descarte artefatual, a remoção de objetos ou espaços arquitetônicos de um sistema comportamental pode ser realizada para modificar o desempenho e a organização das atividades, assim como para redirecionar fluxos de materiais, pessoas e informação entre atividades (Schiffer \& LaMotta 2002).

Para elaboração de modelos expliquem a variação dos comportamentos deposicionais no sistema organizacional do grupo, uma serie de variáveis deve ser levada em consideração dentro do registro arqueológico, que incluem: o local final de deposição; os tipos de artefatos ou elementos depositados juntos; a etapa na história de vida de um objeto em que passou a formar parte do contexto arqueológico; e o tipo de atividades relacionadas aos diferentes eventos deposicionais (Schiffer \& LaMotta 2002).

No sitio Jabuticabeira II observa-se uma multiplicidade de comportamentos deposicionais onde aqueles materiais relacionados com o cotidiano do grupo são remobilizados para formar parte da esfera ritual associada a atividades funerárias. $\mathrm{O}$ volume dos restos arqueofaunísticos recuperados da camada escura e a ausência de áreas de atividade doméstica relacionadas ao sítio, induzem a pensar que os materiais depositados neste sambaqui estão vinculados a resíduos domésticos e não exclusivamente rituais; embora o comportamento que originou sua deposição final seja a materialização de aspectos vinculados com a superestrutura destas comunidades.

O processo de formação cultural deste depósito está predominantemente relacionado ao descarte terciário, mas não exclusivamente, já que contém também 
elementos com outras histórias de deposição cultural (estacas, fogueiras, sepultamentos etc., que representam contextos primários).

Para explicar os comportamentos deposicionais associados com a formação da camada preta, foi elaborado um modelo de cadeia comportamental conjuntamente com a doutoranda Daniela Klokler da Universidade do Arizona, que trabalha com o registro arqueofaunístico associado aos sepultamentos humanos no esclarecimento de questões relacionadas com o ritual funerário.

Esta cadeia comportamental apresenta-se na forma de um diagrama de fluxo que rastreia os materiais arqueológicos (incluindo o registro artefatual dentro do arqueossedimentar), desde o contexto sistêmico ao arqueológico. A partir da avaliação dos componentes do registro arqueológico, localização no sítio e origem natural, relação com os demais componentes e feições antrópicas relacionadas com sua produção, inferem-se as diferentes comportamentos deposicionais que podem ter participado na configuração da camada preta ao longo da evolução cultural deste corpo arqueossedimentar.

A partir da valorização do modelo de cadeia comportamental proposto pode se apreciar o complexo sistema de atividades vinculado com a formação deste sítio, onde materiais pertencentes a esferas tradicionalmente consideradas opostas e dicotômicas se reacomodam para outorgar um novo sentido ao mundo material da comunidade. 


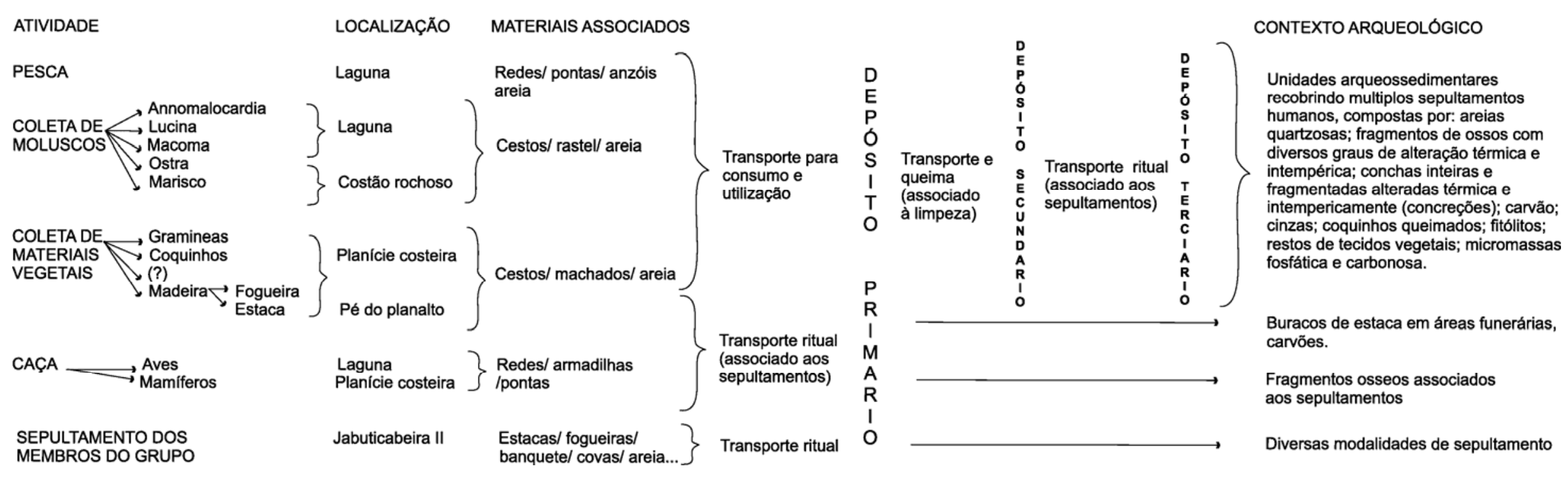

Fig. 52. - Modelo de cadeia comportamental para a formação da camada preta que recobre o sítio Jabuticabeira II. 


\section{BIBLIOGRAFIA}

AFONSO, Marisa \& DEBLASIS, Paulo (1994): Aspectos da formação de um grande sambaqui: alguns indicadores em Espinheiros II, Joinville, SC. Revista do Museu de Arqueologia e Etnologia 4: 21-30.

ANDERTON, R. (1985): Clastic facies models and facies analysis. Sedimentology: recent developments and applied aspects. The Geological Society. Blackwell Scientific Publications, Oxford. pp. 31-47.

ANGULO, R.J.; GIANNINI, P.C.F.; SUGUIO, K. \& PESSENDA, L.C.R. (1999): Relative sea-level change during the last 5500 years in the Laguna-Imbituba region (Santa Catarina, Brazil), based on vermetid radiocarbon ages. Marine Geology 159: 323-339.

ANGULO, R.J; LESSA, G.C; \& SOUZA, M.C. (2006): A critical review of mid- to late-Holocene sea-level fluctuations on the eastern Brazilian coastline. Quaternary Science Reviews 25: 486-506.

BABEL, U. (1975): Micromorphology of soil organic matter. John E. Gieseking (ed.), Soil components: organic components Vol. 1. Springer-Verlag, New York. pp. 369-473.

BAILEY, Geoff (2007): Time perspectivas, palimpsests and the archaeology of time. Jounral of Anthropological Archaeology 26: 198-223.

BARBA, Luis \& ORTIZ, Agustín, (1992): Análisis químico de pisos de ocupación: un caso etnográfico en Tlaxcala, México. Latin American Antiquity Vol. 3, 1: 63-82.

BARBA, Luis; PIERREBOURG, Fabienne de; TREJO, Clauda; ORTIZ, Agustín; LINK, Karl, (1995): Activites humaines refletées dans les sols d'unites d'habitation contemporaine et prehispanique du Yucatan (Mexique): Etudes chimiques, etnoarchéologiques et archéologiques. Revue d'Archéometrie 19: 7995.

BARHAM, A. (1995). Methodological approaches to archaeological recording: Xradiography as an example for a supportive recording, assessment and interpretative techniques. Bates M., Barham, T. and Macphail R.I. (eds.), Archaeological Sediments and Soils. Archetype Books, London. pp. 145-182.

BATE, L. F. (1993): Del registro estático al pasado dinámico: entre un salto mortal y un milagro dialéctico. Arqueología Espacial 18: 1-21.

BECK, Margaret \& HILL, Matthew, (2004): Rubbish, relatives and residence: The family use of middens. Journal of Archaeological Method and Theory 11(3): 297333.

BEHRENSMEYER, A.K. (1978): Taphonomic and ecologic information for bone weathering. Paleobiology 4: 150-162.

BENDAZZOLI, Cintia (2007): O processo de formação dos sambaquis: uma leitura estratigráfica do sítio Jabuticabeira II. Dissertação de Mestrado. Museu de Arqueologia e Etnologia, Universidade de São Paulo.

BERNA, F.; MATTHEWS, A; WEINER, S. (2004): Solubilities of bone mineral from archaeological sites: the recrystallization window. Journal of Archaeological Science 31: 867-882.

BERNA, F; BEHAR, A; SHAHACK-GROSS, R; BERG, J; BOARETTO, E; GILBOA. A; SHARON, I; SHALEV, S; SHILSTEIN S; YAHALOM-MACK, N; ZORN, J; WEINER, S. (2007): Sediments exposed to high temperatures: reconstructing 
pyrotechnological processes in Late Bronze and and Iron Age strata at Tel Dor (Israel). Journal of Archaeological Science 34: 358-373.

BIRKELAND, Peter W., (1999): Soils and Geomorphology. Oxford University Press, Oxford.

BJELAJAC, Victor; LUBY, Edward \& RAY, Rose, (1996): A validations test of a field-based phosphate analysis technique. Journal of Archaeological Science 23: 243-248.

BOGGS, Sam, (1987): Principles of Sedmentology and Stratigraphy. Prentice Hall, New Jersey.

BORJA BARRERA, F. (1993): Formaciones superficiales antrópicas. Aportación al estudio del proceso holoceno de antropización de los sistemas naturales. Procesos Postdeposicionales: Arqueología Espacial 16-17: 29-39.

BRADLEY, Richard (2003): A life less ordinary: the ritualization of the domestic sphere in late prehistoric Europe. Cambridge Archaeological Journal 13(1): 5-23.

BROCHIER, J.E. (1983a): Bergeries et feux de bois néolithiques dans lê Midi de la France. Caractérisation et incendence sur lê raisonnement sédimentologique. Quartär 33/34: 181-193.

(1983b): Conbustion et parcage dês hervibores domestiques. Lê point de vue du sédimentologue. Bulletin de la Socienté Préhistorique Française 80(5): 143-145.

(2002): Les sediments anthropiques: methodes d'etude et perspectives. Jean Claude Miskovsky (ed.). Géologie de la Préhistoire. Geopré, Presses Universitaires de Perpignan, Paris. pp.453-477.

(1990): Des techniques géo-arqueologiques au service de l'etude des paysages et de leur exploitation. Archéologie et Espaces, $X^{e}$ Reencontres Internationales d'Archéologie et d'Histoire, Antibes. pp. 453-471.

BROCHIER, J.E.; VILLA, P. \& GIACOMARRA, M (1992): Shepherds and sediments: geo-ethoarchaeology of pastoral sites. Journal of Anthropological Archaeology 11: 47-102.

BROWN, James (1995): On mortuary analysis -with special reference to the SaxeBinford research programme. Lane Anderson Beck (ed.). Regional approaches to mortuary analysis. Pleumm press, New York.

BULLOCK, P.; FEDOROFF, N; JONGERIUS, A.; STOOPS, G.; TURSINA, T. \& BABEL, U (1985): Handbook for soil thin section description. Waine Research Publications, Wolverhampton.

BUTZER, Kart W., (1989): Arqueología, una ecología del hombre. Ediciones Bellaterra. Barcelona.

CANTI, M.G. \& LINFORD, N. (2000): The effects of fire on archaeological soils and sediments: temperature and colour relationships. Proceedings of the Prehistoric Society 66: 385-395.

CANTI, M.G. (2003): Aspects of the chemical and microscopic characteristics of plant ashes found in archaeological soils. Catena 54: 339-361.

CASTRO, P.V.; LULL, V. \& MICO PÉREZ, R. (1993): Arqueología: algo más que Tafonomía. Arqueología Espacial: Procesos postdeposicionales 16-17: 19-28.

CHARLES, D. K; BUIKSTRA, J. E. (1983): Archaic mortuary sites in the central Mississippi drainage: Distribution, structure and behavioral implications. J. Phillips y J. Brown (eds,). Archaic hunters and gatherers in the American Midwest, Academic Press, pp. 118-143.

CLAASEN, Cheryl (1991): Normative thinking and shell-bearing sites. Archaeological Method and Theory 3: 249-298. 
COHEN-OFRI, I; WEINER, L; BOARETTO, E; MINTZ, G. \& WEINER, S. (2006): Modern and fossil charcoal: aspects of structure and diagenesis. Journal of Archaeological Science 33: 428-439.

COOK, S. F. \& HEIZER, R. F., (1965): Studies on the Chemical Analysis of Archaeological Sites. University of California Press, Berkeley, Los Angeles.

CORNWALL, I.W. (1958): Soils for the archaeologists. Phoenix House, London.

COSTA, M.L; KERN, D; PINTO, A.H; SOUZA, J.R. (2004): The ceramic artefacts in archaeological black earth (terra preta) from Lower Amazon region, Brazil: chemistry and geochemical evolution. Acta Amazonica 34(3): 395-386.

COURTY, Marie Agnes. (1983): Interpretation des aires de combustion par la micromorphology. Bulletin de la Société Prehistorique Française 80(6): 169-171. (2001): Microfacies analysis assisting archaeological stratigraphy. Paul Goldberg, Vance T Holliday \& C. Reid Ferring (eds.). Earth Sciences and Archaeology. Kluwer Academic/Plenum Publishers, New York.

COURTY, M.A.; GOLDBERG, P. \& MACPHAIL, R. (1989): Soils and Micromorphology in Archaeology. Cambridge University Press, Cambridge.

COURTY, Marie Agnès \& FEDOROFF, Nicolas (2002): Micromorphologie des sols et sediments archéologiques. Jean Claude Miskovsky (ed.): Géologie de la Préhistoire. Geopré, Presses Universitaires de Perpignan, Paris. pp: 511-554.

COURTY, Marie-Agnès \& MISKOVSKY, Jean Claude (2002): Place des sédiments archéologiques au sein des depôts queternaires et évolution des techniques. Jean Claude Miskovsky (ed.): Géologie de la Préhistoire. Geopré, Presses Universitaires de Perpignan, Paris. pp.449-451.

CREEMENGS, D.L. (2005): Micromorphology of Cotiga Mound, West Virginia. Geoarchaeology: An International Journal 20(6): 581-597.

CRIADO, Felipe (1993): Visibilidad e interpretación del registro arqueológico. Trabajos de Prehistoria 50: 39-56.

DANIEL, Glyn, (1987): Un siglo y medio de Arqueología. Fondo de Cultura Económica. México.

DARLYMPLE, J.B. (1958): The application of soil micromorphology to fossil soils and other deposits from archaeological sites. Journal of Soil Science 9: 199-205.

DAVIDSON, Donald A., CARTER, Stephen P. \& QUINE, Timothy A, (1992): An evaluation of Micromorphology as an aid to archaeological interpretation. Geoarchaeology: An International Journal 7(1): 55-65.

DE SOUZA FALCÂO, P.N.; COMERFORD, N. \& LEHMANN, J. (2003): Determining nutrient bioavailability of Amazonian dark earth soils: methodological challenges. Amazonian Dark Earths: origin, properties, management. Kluwer Academic Publishers, Netherlands. pp: 255-270.

DEAN, W.E. (1974): Determination of carbonate and organic matter in calcareous sediments and sedimentary rocks by loss on ignition: comparison with other methods. Journal of Sedimentary Petrology 44(1): 242-248.

DEBLASIS, P.; FISH, S. K.; GASPAR, M.D.; FISH, P.R. (1998); Some references for the discussion of complexity among the sambaqui moundbuilders from the southern shores of Brazil; Revista de Arqueologia Americana 15: 75-105.

DEBLASIS, P.; GASPAR, M.D.; GIANNINI, P.C.; FIGUTY, L.; EGGERS, S.; SCHEEL-YBERT, R.; AFONSO, M.C.; FARIAS, D.S.; KNEIP, A.; MENDONÇA, C.A. \& YBERT, J.P. (2004); Projeto Arqueológico do Camacho, Processos Formativos nos Sambaquis de Camacho, SC: Padrões Funerários e Atividades Cotidianas, Relatório de Pesquisa FAPESP (98/8114-3). 
DEBLASIS, P.; KNEIP, A.; SCHEEL-YBERT, R.; GIANNINI, P.C. \& GASPAR, M. D. (2007): Sambaquis e paisagem: dinâmica natural e arqueologia regional no litoral sul do Brasil. Arqueologia Sudamericanca/ Arqueologia Sul-americana 3 (1): 29-61.

DELVIGNE, Jean E., (1998): Atlas of micromorphology of mineral alterations and weathering. The Canadian Mineralogist, Special publication: 3. Ottawa, Ontario.

DIMBLEBY, G.W. (1967): Plants and Archaeology. John Baker. London.

DINCAUZE, Dena F., (2000): Environmental Archaeology: Principles and Practice. Cambridge University Press, Cambridge.

DUCHAUFOUR, Phillip, (1975): Manual de Edafología. Editorial Masson, Barcelona.

DUNNEL, Robert C. (1977): Prehistoria moderna. Ediciones Istmo, Madrid.

EIDT, Robert C. (1973): A rapid chemical field test for archaeological site surveying. American Antiquity 38(2): 206-210.

(1977): Detection and examination of anthrosols by phosphate analysis. Science 197: 1327-133.

(1985): Theoretical and Practical Considerations in the Analysis of Anthrosols. George Rapp \& John A. Gifford (eds.) Archaeological Geology. Yale University Press, New Haven and London.

EIDT, Robert C. \& WOODS, William, (1974): Abandoned settlement analysis: Theory and Practice. Field Test Associates, Wisconsin.

EMBRAPA Solos, (1999): Sistema Brasileira de Classificação de Solos. Serviço de produção de informação, Brasília.

ÉTIEGNI, L. \& CAMPBELL, A.G. (1991): Physical and chemical characteristics of wood ash. Bioresource Technology 37: 173-178.

EVANS, J., \& O'CONNOR, T., (1999): Environmental Archaeology: Principles and Methods. Sutton Publishers Ltd., Gloucestershire.

FERNANDEZ, F.G.; TERRY, R.; INOMATA, T. \& EBERL, M. (2002): An ethnoarchaeological study of chemical residues in the floors and soils of Q'eqchi' Maya houses at Las Pozas, Guatemala. Geoarchaeology: An international Journal 17(6): 487-519.

FIGUTY, Levy \& KLÖKLER, Daniela (1996): Resultados preliminares dos vestígios zooarqueológicos do sambaqui Espinheiros II (Joinville, SC). Revista do Museu de Arqueologia e Etnologia 6: 169-188.

FISH, S. K; DE BLASIS, P.; GASPAR, M.D.; FISH, P.R.; (2000); Eventos incrementais na construção de sambaquis, litoral Sul do estado de Santa Catarina; Revista do Museu de Arqueologia e Etnologia10: 69-87.

FISHER, W.L. \& MCGOWEN, J.H. (1969): Depositional systems in Wilcox group (Eocene) of Texas and their relation to occurrence of oil and gas. The American Association of Petroleum Geologists Bulletin 53(1): 30-54.

FOLK (1959): Practical petrographic classification of limestones. Bulletin of the American Association of Petrological Geology 43: 1-38.

FRITZ, W. and MOORE, J.N. (1988). Basics of Physical Stratigraphy and Sedimentology. John Willey and Sons, New York.

GASCHE, Hermann \& TUNCA, Onhan, (1983): Guide to archeoestratigraphic classification and terminology: definitions and Principles. Journal of Field Archaeology 10(3): 325-335..

GASPAR, Maria Dulce (1998): Considerations of the sambaquís of the brazilian coast. Antiquity 72 (277): 592-615. 
(2000): Construcción de "sambaquís" y ocupación del territorio brasileño por pescadores, recolectores e cazadores. A. Duran \& R. Bracco (eds.), Arqueologia de las Tierras Bajas. Ministério de Educaciõn y Cultura. pp.333-342.

GASPAR, Maria Dulce \& DEBLASIS, Paulo A. (1992): Construção de Sambaquis. Anais da VI Reunião Científica da Sociedade de Arqueologia Brasileira 2: 811820.

GASPAR, M.D.; FISH, P.; SHEEL-YBERT, R.; FIGUTI, L.; KLOKER, D.; KNEIP, A.; BRUM RIBEIRO, L.; DE FARIAS, D.; AFONSO, M.; KARL, R.; EGGERS, S.; FISH, S.K.; DE BLASIS, P. (2002); Padrão de assentamento e formação de sambaquis: arqueologia e preservação em Santa Catarina. Revista de Arqueologia do IPHAN 11: 57-62.

GÉ, T.; COURTY, M.A.; MATTHEWS, W. \& WATTEZ, J. (1993): Sedimentary formations processes of occupation surfaces. P. Goldberg, D. T. Nash \& M. D. Petraglia (eds.), Formation Processes in Archaeological Contexts. Monographs in World Archaeology, 17: 149-163. Prehistory Press. Madison, Wisconsin.

GEBHARDT, Anne \& LANGOHR, Roger, (1999): Micromorphological study of construction materials and living floors in the medieval motte of Werken (West Flanders, Belgium). Geoarchaeology: An International Journal 17 (7): 595-620.

GIANNINI, Paulo César Fonseca, (1993): Sistemas deposicionais no Quaternário costeiro entre Jaguaruna e Imbituba, Santa Catarina. Tese de Doutorado, Instituto de Goeciências, Universidade de São Paulo.

(2002): Complexo lagunar centro-sul catarinense: valioso patrimônio sedimentológico, arqueológico e histórico. C. Schobbenhaus, D.A. Campos, E.T. Queiroz, M. Winge \& M. Bebert-born (eds.), Sítios geológicos e paleontológicos do Brasil. DNPN, SIGEP-Comissão Brasileira de Sítios Geológicos e Paleontológicos 1: 213-222.

GIANNINI, P.C.F.; DEBLASIS, P; SAWAKUCHI, A.O. \& AMARAL, P.G.C. (2005): Processos e materiais geológicos e a contrução de sambaquis no litoral sul de Santa Catarina. Congresso da Associação Brasileira de Estudos do Quaternário 11. Resumos expandidos ABEQUA, Guarapari.

GIANNINI, P.C.F.; RICCOMINI C., (2000): Sedimentos e processos sedimentares. W. Teixeira, T.R. Fairchild, M.C. Toledo \& F. Taioli (eds.), Descifrando a Terra. Cap. 9: 167-180. Oficina de textos, São Paulo.

GIANNINI, P.C.F. \& SANTOS E.R., (1994): Padrões de variação espacial e temporal na morfologia de dunas de orla costeira no centro-sul catarinense. Boletim Paranaense de Geociências 42: 73-96.

GIANNINI, P.C.F. \& SUGUIO, K. (1994): Diferenciação entre depósitos eólicos quaternários na costa centro-sul de Santa Catarina. Congresso Brasileiro de Geologia 38: Resumos expandidos. SBG, Balneário Camboriú. pp: 402-403.

GIANNINI, P.C.F.; SAWAKUCHI, A.O. \& MARTINHO, C.T. (2001): A estratigrafia de seqüências na evolução das dunas costeiras de Santa Catarina, Sul do Brasil. Actas do Congresso do Quaternário dos países de língua ibérica, 1, Lisboa. Sociedade Geológica de Portugal, Grupo de Trabalho Português para o Estudo do Quaternário e Associação Española para el Estudio del Quaternário. pp.117120.

GIANNINI, P.C.F.; SAWAKUCHI, A.O.; MARTINHO, C.T.; \& TATUMI, S.H. (2007): Eolian depositional episodes controlled by Late Quaternary relative sea level changes on the Laguna-Imbituba coast, South Brazil. Marine Geology 237: 143-168. 
GILBERTSON, D.D. (1995). Study of lithostratigraphy and Lithofacies. A selective review of research developments in the last decade and their applications to geoarchaeology. In Barham T, Bates, M. and Macphail R.I. (eds.), Archaeological Sediments and Soils. Archetype Books, London. pp. 99-144.

GLADFELTER, Bruce G., (1977): Geoarchaeology: the geomorphologist and archaeology. American Antiquity 41(4): 519-538.

(1981): Developments and directions in Geoarchaeology. M. Schiffer (ed.). Advances in Archaeological Method and Theory. 4: 343-363.

GLASER, B.; BALASHOV, E.; HAUMAIER, L.; GUGGENBERGER, G. \& ZECH, W. (2000): Black carbon in density fractions of anthropogenic soils of the brazilian amazon region. Organic Geochemistry 31: 669-678.

GLASER, B.; HAUMEIER, E. \& ZECH, W. (1998): Black carbon in soils: the use of benzenecarboxylic acids as specific markers. Organic Geochaemistry 29: 811819.

GOLDBERG, Paul, (1979): Micromorphology of sediments from Hayonim cave, Israel. Catena 6: 167-181.

(1983): Application of micromorphology in Archaeology. Bullock \& Murphy (eds.), Soil Micromorphology. A.B. Academic Press, Berkshamsted. pp. 139-150.

(1992): Micromorphology, Soils and Archaeological Sites. Vance T. Hollyday (ed.), Soils in Archaeology, Landscape evolution and human occupation. Smithsonian Institution Press, Washington and London. pp: 145-168.

GOLDBERG, P. \& MACPHAIL, R. (1993): Short contribution: strategies and techniques in collecting micromorphology samples. Geoarchaeology: an international journal 18(5): 571-578.

GOLDBERG, P. \& MACPHAIL, R. (2006). Practical and Theoretical Geoarchaeology, Blackwell Publishing, Oxford.

GOLDBERG, P.S. \& NATHAN Y. (1975): The phosphate mineralogy of et-Tabun cave, Mount Carmel, Israel. Mineralogical Magazine 40: 253-258.

GOLDBERG, Paul \& WHITBREAD, Ian (1993): Micromorphological study of a bedouin tent floor. P. Goldberg, D.T. Nash \& M.D. Petraglia (eds.). Formation Processes in Archaeological Context. Prehistoric Press, Madison. pp. 156-188.

GORDON, Claire C. \& BUIKSTRA, Jane E. (1981): Soil pH, bone preservation and sampling bias at mortuary sites. American Antiquity 46(3): 566-571.

GRIFITH, M. A., (1980): A pedological investigation of an archaeological site in Ontario, Canada, I. An examination of the soils in and adjacent to a former village. Geoderma 24: 327-336.

HARRIS, Edward C., (1991): Princípios de estratigrafia arqueológica. Editorial Crítica. Barcelona.

HASSAN, Fekri (1979). Geoarcheology: the geologist and archaeology. American Antiquity 44(2): 267-270.

HEDGES, R.E.M. (2002): Bone diagenesis: an overview of processes. Archaeometry 44: 319-328.

HERZ, Norman \& GARRISON, Ervan, (1998): Geological Methods for Archaeology. Oxford University Press, Oxford.

HESSE, P.R. (1971): A textbook of soil chemical analyses. Williams Clowes and Sons Ltd. London.

HODDER, I. (1999). The archaeological process, Blackwell Publishing, Oxford. 
HOLLIDAY, Vance T. (2004): Soils in Archaeological Research. Oxford University Press. Oxford.

HOMSEY, L.K. \& CAPO, R.C. (2006): Integrating geochemistry and micromorphology to interpret feature at Dust Cave, a paleo-indian through middle archaic site in Northwest Alabama. Geoarchaeology: an International Journal 21(3): 237-269.

KARKANAS, Panagiotis, (2002): Micromorphological studies of greek prehistoric sites: New insights on the interpretation of the archaeological record. Geoarchaeology: An International Journal 17(3): 327-259.

KARKANAS, P.; BAR-YOSEF, O.; GOLDBERG, P. \& WEINER, S. (2000): Diagenesis in prehistoric caves: the use of minerals that form in situ to asses the completeness of the archaeological record. Journal of Archaeological Science 27: 915-929.

KARL, Rick J. (2000): The relative chronology of cultural episodes at the coastal sambaqui Jaboticabeira II, Santa Catarina, Brazil. M.A. in Archaeology, Department of Anthropology of the University of Arizona, Tucson.

KIRCHMANN, Holger \& SPRINGOB, Gunter (2002): C-rich sandy $A_{p}$ horizons of northwest Europe contain a large fraction of very stable organic matter. $17^{\text {th }}$ WCSS 14-21 August. Thailand.

KITTLEMAN Jr. L.R. (1964): Application of Rosin's distribution to size-frequency analysis of clastic rocks. Journal of Sedimentary Petrology 34: 483-502.

KLÖKLER, Daniela M. (2001): Construindo ou deixando um sambaqui? Análise de sedimentos de um sambaqui do litoral meridional brasileiro - processos formativos, região de Laguna SC. Dissertação de Mestrado. Museu de Arqueologia e Etnologia, Universidade de São Paulo.

KLÖKLER, D. \& GASPAR, M.D. (2004): Time to die, time to eat: ritual in shell mounds. Society for American Archaeology, Montreal.

KNEIP, Andreas, (2004): O Povo da Lagoa: Uso do SIG para modelamento e simulação na área arqueológica do Camacho. Tese de doutorado, Museu de Arqueologia e Etnologia, Universidade de São Paulo.

KUBIENA, W.L. (1938): Micropedology. Collegiate Press, Iowa.

LA MOTTA, Vincent M. \& SCHIFFER, Michael (2002): Behavioral Archaeology: towards a new synthesis. Ian Hodder (ed.), Archaeological Theory Today, Polity Press, Cambridge. pp. 14-64.

LEACH, E. K. (1992): On the definition of Geoarchaeology. Geoarchaeology: An International Journal 7(5): 405-417.

LEHMANN, J.; CAMPOS, C.V.; MACEDO, J.L.V. \& GERMAN, L. (2004): Sequential $\mathrm{P}$ fractionation of relict anthropogenic dark earths of Amazonia. B. Glaser \& W.I. Woods (eds.), Amazonian Dark Earths: Explorations in Time and Space. Springer, Berlin. pp: 113-123.

LEHMANN, J.; DA SILVA, J.P.; STEINER, C.; NEHLS, T.; ZECH, W. \& GLASER, B. (2003): Nutrient availability and leaching in an archaeological anthrosol and a ferrasol of the central amazon basin: fertilizer, manure and charcoal amendments. Plant and Soil 249: 343-357.

LEONARDI, G. (1992): Il deposito archeologico: bacini, processi formativi e transformativi. G. Leonardi (ed.), Processi Formativi della stratificazione archeologica. Saltuarie dal Laboratório del Piovego. pp: 13-47.

LINDERHOLM, Johan \& LUNDBERG, Erik, (1994): Chemical characterization of various archaeological soil samples using main and trace elements determined by 
Inductively Coupled Plasma Atomic Emisson Spectometry. Journal of Archaeological Science 21: 303-314.

LINSE, Angela R (1992): Is bone safe in a shell midden?. Julie Stein (ed.). Deciphering a shell midden. Academic Press.

LUCAS, Jacques \& PRÉVÔT, Lilian E. (1991): Phosphates and fossil preservation. Peter A. Allison \& Derek E.G. Briggs (eds.). Taphonomy: releasing the data locked in the fossil record, vol. 9 of Topics in Geobiology. Plenum Press, New York. pp: 389-409.

LYON, T.L. \& BUCKMAN, H.O. (1944): Edafología. Acme Agency. Buenos Aires.

MACCUTCHEON, Patrick T. (1992): Burned archaeological bone. Julie Stein (ed.), Deciphering a Shell Midden. Academic Press, New York. pp: 347-370.

MACPHAIL, R.I. (1983): The micromorphology of dark earth from Gloucester, London and Norwich: an analysis of urban anthropogenic deposits from the Late Roman to Early Medieval periods in England. Bullock \& Murphy (eds.), Soil Micromorphology, Academic Publishers, Berkhamsted. pp. 245-252.

MACPHAIL, R.I.; COURTY, M.A. \& GEBHARDT, A (1990a): Soil Micromorphological evidence of early agriculture in North-West Europe. World Archaeology 22(1): 53-69.

MACPHAIL, Richard; COURTY, Marie Agnes \& GOLDBERG, Paul (1990b): Soil micromorphology in archaeology. Endeavour 14(4): 163-171.

MACPHAIL, Richard \& CRUISE, Jill (2001): The soil micromorphologist as team player: a multianalytical approach to the study of European microstratigraphy. Paul Goldberg, Vance T Holliday \& C. Reid Ferring. Earth Sciences and Archaeology. Kluwer Academic/Plenum Publishers, New York. pp. 241-267.

MACPHAIL, R. I.; CRUISE, G.M.; ALLEN, M.J.; LINDERHOLM, J. \& REYNOLDS, P. (2004): Archaeological soil and pollen analysis of experimental floor deposits; with special reference to Butser Ancient Farm, Hampshire, UK. Journal of Archaeological Science 31: 175-191.

MARTINHO, Thaís (2004): Morfodinâmica e sedimentología de campos de dunas transgressivas da região de Jaguaruna-Imbituba, Santa Catarina. Dissertação de mestrado, Instituto de Geociências, Universidade de São Paulo.

MATTHEWS, W; FRENCH, C.A.I.; LAWRENCE, T.; CUTLER, D.F. \& JONES, M.K., (1997): Microstratigraphic traces of site formation processes and human activities. World Archaeology: High definition archaeology 29(2): 281-308.

MAZINI, Erico B (2007): Terra preta e concreções carbonáticas no sambaqui de Jabuticabeira II: um modelo de evolução diagenética. Relatório de iniciação científica PIBIC/CNPq. Orientado por Paulo C.F. Giannini.

MEJÍA P.C., Elizabeth \& BARBA P., Luis, (1998): El análisis de fosfatos en la arqueoogia: História y perspectivas. Anales de Antropología 25: 127-147.

MIALL, D. (1990): Principles of sedimentary basin analysis. Springer-Verlag, New York.

MIDDLETON, W. D., (2004): Identifying chemical activity residues on prehistoric house floors: a methodology and rationale for multi-elemental characterization of a mild acid extract of anthropogenic sediments. Archaeometry 46(1): 47-65.

MIDDLETON William D. \& PRICE, Douglas T., (1996): Identification of activity areas by Multi-element characterization of sediments from modern and archaeological house floors using Inductively Coupled Plasma Emisson Spectometry. Journal of Archaeological Science 23: 673-687. 
MOLINOS, M.; RISQUEZ, A.; SANCHEZ, A. \& ESTEBAN, A. (1993): Hechos deposicionales y postdeposicionales: Aspectos metodológicos para la definición de la "Coyuntura Cero". Procesos Postdeposicionales: Arqueologia Espacial 1617: 279-295.

NEEDHAM, Stuart \& SPENCE, Tony, (1997): Refuse and the formation of middens. Antiquity 71: 77-90.

NICHOLSON, Rebecca A. (1993): A morphological investigation of burnt animal bone and an evaluation of its utility in archaeology. Journal of Archaeological Science 20: 411-428.

NISHIDA, Paula (2007): A coisa ficou preta: estudo do processo de formação da terra preta do sítio arqueológico Jabuticabeira II. Tese de Doutorado, Museu de Arqueologia e Etnologia, Universidade de São Paulo.

OKUMURA, Mercedes \& EGGERS, Sabine (2005): The people of Jabuticabeira II: reconstruction of the way of life in a Brazilian shellmound. Journal of Comparative Human Biology 55:263-281.

ORQUERA L.A. \& PIANA E.L. (1992): Un paso hacia la resolución del palimpsesto. L.A. Borrero y L. Lanata (eds.), Análisis Espacial en la Arqueología Patagónica, Ayllu, Buenos Aires. pp. 21-52.

PARNELL, J. J.; TERRY, R.E.; SHEETS, P. (2002): Soil chemichal analysis of ancient activities in Cerén, El Salvador: A case study of a rapidly abandoned site. American Antiquity 13(3): 331-342.

PATE, F.D. \& HUTTON, J.T. (1988): The use of soil chemistry data to address postmortem diagenesis in bone mineral. Journal of Archaeological Science 15: 729739.

POPE, Gregory A. \& RUBENSTEIN, Ruth, (1999): Anthroweathering: Theoretical framework and case study for human-impacted weathering. Geoarchaeology: An International Journal 14(3): 247-264.

POSNER, A.S.; BLUMENTHAL, N.C. \& BETTS, F (1984): Chemistry and structure of precipitated hydroxyapatites. J.O. Nriagu \& P.B. Moore (eds.), Phosphate Minerals. Springer-Verlag, Berlin. pp: 330-349.

PROUDFOOT, B., (1976): The analysis and interpretation of soil phosphorous un archaeological contexts. D. A. Davidson \& M. L. Shackley (eds.), Geoarchaeology: Earth Science and the Past. Duckworth, London.

RAPP, George, HILL, Christopher L., (1998): Geoarchaeology, the Earth-Science approach to archaeological interpretation. Yale University Press, New Haven and London.

READING, H.G. (1986): Facies. Sedimentary environments and facies. Blackwell Scientific Publications, Cambridge. cap. 2.

RENFREW, Collin, (1976): Archaeology and the Earth Sciences. D. A. Davidson \& M.L. Shackley (ed.), Geoarchaeology: Earth Science and the Past. Duckworth. London.

RENFEW, Collin \& BAHN, Paul (1993): Arqueología. Teoría, Métodos y Práctica, Editorial Akal, Madrid.

RISCH, R., (1998): Análisis paleoeconómico y medios de producción líticos: el caso de Fuente Álamo. Germán Delibes de Castro (ed.). Minerales y metales en la prehistoria reciente, algunos testimonios de su explotación y laboreo en la Península Ibérica. Fundación Duques de Soria, secretariado de publicaciones e intercambio científico, Universidad de Valladolid. 
RODRIGUEZ ARIZA, M.O. (1993): Los procesos de formación y transformación del registro arqueológico en los estudios antracológicos. Procesos Postdeposicionales: Arqueología Espacial 16-17: 371-390.

SANCHEZ, Alberto \& CAÑABATE, Maria Luisa (1998): Indicadores químicos para la Arqueología.Universidad del Jaén, Centro Andaluz de Arqueología Ibérica. Jaén.

SAWAKUCHI, André Oliveira, (2003): Sistemas deposicionais eólicos quaternários na costa centro-sul catarinense: relações com o nível do mar. Dissertação de mestrado. Instituto de Geociências, Universidade de São Paulo.

SAWAKUCHI, A.O. \& GIANNINI, P.C.F. (2006). Complexidade em sistemas deposicionais. Revista Brasileira de Geociências 36:347-358.

SAXE, A. (1970): Social dimensions of mortuary practices. Ph. D Dissertation. University of Michigan, Ann Arbor.

SCHIEGL, S.; LEV-YADUN, S.; BAR-YOSEF, O.; EL GORESY, A. \& WEINER, S. (1994): Siliceous aggregates from prehistoric wood ash: a major component of sediments in Kebara and Hayonim caves (Israel). Isreal Journal of Earth Sciences 43: 267-278.

SCHIEGL, S.; GOLDBERG, P.; BAR-YOSEF, O. \& WEINER, S. (1996): Ash deposits in Hayonim and Kebara caves, Israel: macroscopic, microscopic and mineralogical observations, and their archaeological implications. Journal of Archaeological Science 23: 763-781.

SCHIFFER, Michael, (1972): Archaeological Context and the Systemic Context. American Antiquity 37(2): 156-165.

(1983): Toward the Identification of Formation Processes. American Antiquity 48(4): 675-706.

(1987): Formation Process of the Archaeological Record. University of New Mexico. Albuquerque.

(1988): The structure of archaeological theory. American Antiquity 53: 461-485.

SCHLEYER, Rupercht (1987): The goodness of fit to ideal Gauss and Rosin distributions: a new grain-size parameter. Journal of Sedimentary Petrology 57(5): 871-880.

SCHULDENREIN, Joseph, (1995): Geochemistry, phosphate fractionation, and the detection of activity areas at prehistoric North American sites. Pedological Perspectives in Archaeological Research. Soil Science Society of America Special Publication 44. pp. 107-131.

SCHMIDT, Michael W. \& NOACK, Angela G. (2000): Black carbon in soils and sediments: Analyses, distribution, implications, and current challenges. Global Biochemical Cycles 14 (3): 777-793.

SELLEY, Richard C. (1976). An Introduction to Sedimentology, Academic Press, Orlando.

SHIPMAN, P.; FOSTER, G. \& SCHOENINGER, M. (1984): Burnt bones and teeth: an experimental study of color, morphology, crystal structure and shrinkage. Journal of Archaeological Science 22: 223-237.

SIMPSON, Ian A. \& BARRET, James H., (1996): Interpretation of midden formation processes at Robert's Haven, Caithness, Scotland using thin section micromorphology. Journal of Archaeological Science 23: 543-556.

SIMPSON, Ian A; MILEK, Karen B \& GUOMUNDSSON, Garoar (1999): A reinterpretation of the great pit at Hofstaoir, Iceland using sediment thin section micromorphology. Geoarchaeology: An International Journal 14: 511-530. 
SIMPSON, Ian A.; PEDIRAKIS, Sophia; COOK, Gordon; CAMPBELL, John L. \& TEESDALE, William, (2000): Cultural sediment analyses and transitions in early fishing activity at Langensværet, Vesterålen, Northern Norway. Geoarchaeology: An International Journal 15(8): 743-763.

SIMPSON, Ian A.; VESTEINSSON, Orri; ADDERLEY Paul W. \& MACGOVERN, Thomas (2003): Fuel resource utilization in landscape settlement. Journal of Archaeological Science 30: 1401-1420.

SJOBERG, Alf, (1976): Phosphate Analysis of Anthropic Soils. Journal of Field Archaeology. 3(4): 447-454.

SMITH, C.I.; NIELSEN-MARSH, C.M.; JANS, M.M.E. \& COLLINS, M.J. (2007): Bone diagenesis in the European Holocene I: patterns and mechanisms. Journal of Archaeological Science 34: 1485-1493.

Soil Survey Staff, (1998): Keys to Soil Taxonomy. United States Department of Agriculture, Natural Resources Conservation Service.

SOLÉ, Albert (1991): Micromorfología: Métodos y técnicas microscópicas aplicadas a la Arqueología. Asunción Vila (ed.), Arqueología: Nuevas tendencias. CSIC, Madrid. pp. 23-43.

SOLÈ, Alert \& VILA, Asunción (1990): La micromorfología de suelos aplicada a la arqueología. Dos casos a modo de ejemplo: El Cingle Vermell (Osona) y Mediona I (Alt Penedes). Xábiga: Revista de Cultura 6: 30-42.

SPENCER, D.W. (1963): The interpretation of grain size distributions curves of clastic sediments. Journal of Sedimentary Petrology 33:180-190.

STEIN, Julie (1983): Earthworm Activity: A source of potential disturbance of archaeological sediments. American Antiquity 28(2): 277-289.

(1984): Organic Matter and Cabonates in Archaeological Sites. Journal of Field Archaeology 11(2): 239-246.

(1985): Interpreting Sediments in Cultural Settings. J. Stein \& W. Farrand (eds.), Archaeological Sediments in Context. Center for the study of early man, University of Main, Orono.

(1987): Deposits for Archaeologists. M. Schiffer (ed.), Advances in Archaeological Method and Theory 11: 337-395.

(1990): Archaeological Stratigraphy. N.P. Lasca \& J. Donahue (eds.), Archaeological Geology of North America. Geological Society of America, Centennial Special Volume 4: 523-523. Boulder, Colorado.

(1992): Interpreting stratification of a shell midden. Julie K. Stein (ed.), Deciphering a shell midden. Academic Press. pp. 71-94.

(1993): Scale in archaeology, geosciences, and geoarchaeology. J. Stein \& A. Linse (eds.), Effects of Scale on archaeological and Geoscientific perspectives. Geological Society for America Special Paper 283: 1-10. Boulder, Colorado.

(1996): Geoarchaeology and Archaeostratigraphy. E. Reitz, L. Newsom \& S. Scudder (eds.), Case Studies in Environmental Archaeology. Plenum Press, New York. pp.: 35-54.

(2001a): A review of site formation processes and their relevance to Geoarchaeology. P. Goldberg, V.T. Holliday \& C.R. Ferring (eds.), Earth Sciences and Archaeology. Kluwer Academic, Plenum Publishers. New York. pp:37-51.

(2001b): Archaeological sediments in cultural environments. Julie K. Stein \& William R. Farrand (eds.). Sediments in Archaeological Context. University of Utah Press. Salt Lake City. pp: 1-28. 
STEIN, J.K.; KORNBACHER, K.D. \& TYLER, J.L. (1992): British camp shell midden stratigraphy. Julie K. Stein (ed.), Deciphering a shell midden. Academic Press. pp. 95-134.

STEINER, M.C.; WEINER, S. \& BAR-YOSEF, O. (1995): Differential burning, and fragmentation of archaeological bone. Journal of Archaeological Science 22: 223237.

STOOPS, Georges (1986): Multilingual translation of the terminology used in the "Handbook for soil thin section description". Pédologie 36: 225-233.

STOOPS, Georges (2003): Guidelines for analysis and description of soil and regolith thin sections. Soil Science Society of America, Madison.

SUGUIO, Kenitiro, (1980): Rochas Sedimentares. Editora Edgard Blüchter ltda, São Paulo.

(1998): Dicionário de Geologia Sedimentar e áreas afins. Bertrand Brasil, Rio de Janeiro.

TRUEMAN, C.N.G.; BEHRENSMEYER, A.K.; TUROSS, N. \& WEINER, S. (2004): Mineralogical and compositional changes in bones exposed in soil surfaces in Amboseli National Park, Kenya: diagenetic mechanisms and the role of sediment pore fluids. Journal of Archaeological Science 31: 721-739.

VILA, Asumpció \& ESTEVEZ, Jordi (2000): Estratigrafías en contexto. KREI: Círculo de Estratigrafía Analítica 5: 29-61.

VILLA, Paola, (1982): Conjoinable pieces and site formation processes. American Antiquity 47(2): 276-290.

VISHER, G.S. (1969): Grain size distributions and depositional processes. Journal of Sedimentary Petrology 39: 1074-1106.

WALKER, Roger G., (1983): Facies Models. Geological Association of Canada, Toronto.

WATERS, Michael, (1992): Principles of Geoarchaeology: A North American Perspective. The University of Arizona Press. Tucson.

WEINER, S.; GOLDBERG, P. \& BAR-YOSEF, O. (2002): Three-dimensional distribution of minerals in the sediments of Hayonim cave, Israel: diagenetic processes and archaeological implications. Journal of Archaeological Science 29: 1289-1308.

WHITE, E.M. \& HANNUS, L.A. (1981): Approximate method for estimating soil charcoal contents. Communications in Soil Science and Plant Analyses 12 (3): 363-371.

WILSON, Douglas, (1994): Identification and assessment of secondary refuse aggregates. Journal of Archaeological method and theory 1(1): 41-68. 